\title{
Reference-Site Environmental \\ Document for a Monitored \\ Retrievable Storage Facility: \\ Backup Waste Management \\ Option for Handling 1800 MTU Per Year
}
D. J. Silviera
M. J. Scott
R. L. Aaberg
G. H. Sewart
C. E. Cushing
D. L. Strenge
A. Marshall

June 1985

Prepared for the U.S. Department of Energy under Contract DE-AC06-76RLO 1830

Pacific Northwest Laboratory Operated for the U.S. Department of Energy by Battelle Memorial Institute 


\title{
DISCLAIMER
}

This report was prepared as an account of work sponsored by an agency of the United States Government. Neither the United States Government nor any agency thereof, nor any of their employees, makes any warranty, express or implied, or assumes any legal liability or responsibility for the accuracy, completeness, or usefulness of any information, apparatus, product, or process disclosed, or represents that its use would not infringe privately owned rights. Reference herein to any specific commercial product, process, or service by trade name, trademark, manufacturer, or otherwise, does not necessarily constitute or imply its endorsement, recommendation, or favoring by the United States Government or any agency thereof. The views and opinions of authors expressed herein do not necessarily state or reflect those of the United States Government or any agency thereof.

\author{
PACIFIC NORTHWEST LABORATORY \\ operated by \\ BATTELLE \\ for the \\ UNITED STATES DEPARTMENT OF ENERGY \\ under Contract DE-AC06-76RLO 1830
}

\begin{tabular}{|c|c|}
\hline \multicolumn{2}{|c|}{ Printed in the United States of America } \\
\hline \multicolumn{2}{|c|}{$\begin{array}{l}\text { Available from } \\
\text { National Technical Information Service }\end{array}$} \\
\hline \multirow{2}{*}{\multicolumn{2}{|c|}{$\begin{array}{l}\text { National Technical Information Service } \\
\text { United States Department of Commerce }\end{array}$}} \\
\hline & \\
\hline 5285 Port Royal Road & Springfield, Virginia 22161 \\
\hline \multirow{2}{*}{\multicolumn{2}{|c|}{$\begin{array}{l}\text { NTIS Price Codes } \\
\text { Microfiche A01 }\end{array}$}} \\
\hline & \\
\hline \multicolumn{2}{|c|}{ Printed Copy } \\
\hline & \\
\hline Pages & Codes \\
\hline 001-025 & A02 \\
\hline 026-050 & A03 \\
\hline 051-075 & A04 \\
\hline $076-100$ & A0S \\
\hline $101-125$ & A06 \\
\hline $126-150$ & A07 \\
\hline $151-175$ & $A 08$ \\
\hline $176-200$ & $A 09$ \\
\hline $201-225$ & A010 \\
\hline 226-250 & A011 \\
\hline $251-275$ & A012 \\
\hline $276-300$ & $A 013$ \\
\hline
\end{tabular}


REFERENCE-SITE ENVIRONMENTAL DOCUMENT FOR

A MONITORED RETRIEVABLE STORAGE FACILITY:

BACKUP WASTE MANAGEMENT OPTION

FOR HANDLING 1800 MTU PER YEAR

D. J. Silviera

R. L. Aaberg

C. E. Cushing

A. Marshall

M. J. Scott

G. H. Sewart

D. L. Strenge

June 1985

Prepared for

the U.S. Department of Energy

under Contract DE-AC06-76RLO 1830

Pacific Northwest Laboratory

Richland, Washington 99352 
On January 7, 1983, President Reagan signed the Nuclear Waste Policy Act (NwPA) of 1982, which establishes the federal policy for disposal of spent nuclear fuel and high-level radioactive waste. The NwPA instructs the Secretary of Energy to start accepting comercial spent fuel and high-level waste for disposal in a deep geologic repository by january 1998. The NwPA also states that temporary storage of highlevel radioactive waste or spent fuel in a monitored retrievable storage (MRS) facility is an option for providing safe and reliable management of such waste or spent fuel. An MRS facility could ensure that the federal government could accept nuclear wastes even if the geologic repository were delayed.

Section 141 of the NWPA instructs the Secretary of Energy to prepare a proposal for constructing one or more MRS facilities. The NWPA also instructs the Secretary of Energy to prepare and submit, along with the proposal, an environmental assessment (EA) that incluces an andlysis of the reiative advantages and disadvantages of at least five alternative combinations of MRS jesign concepts and sites.

To meet the requirements of the NWPA, the U.S. Departnent of Energy (DOE) has tvaluated 1) a backup MRS facility that would be constructed only if there is a significant delay in the repository program and 2) an integral MRS facility that would receive, prepare, package, and temporarily store spent fuel for subsequent disposal at the repository. This environmental document (ED) evaluates the backup MRS facility that would handle 1800 MTU per year. The EA that will be submitted to Congress along with the proposal will evaluate the integral MRS facility that would handle 3600 MTU per year. Another significant difference between this ED and the EA is the use of reference sites for this ED (since actual sites were not nominated until this work was nearly completed) and the use of three specific sites nominated by the DoE for the EA. The analyses in the ED are useful in two ways: 1) they provide a referenceable basis for climate not being a significant discriminator in siting and 2) they could provide early insight to states and to the public about the types of impacts of an MRS facility.

This ED provides environmental perspectives reievant to siting, sturage design concepts, and potential long-tern impacts. Environmental impacts of an MRS facility are evaluated for two design concepts and three reference sites, for a total of six site/concept combinations. These impacts are based in part on conceptual design information and preliminary engineering data. Both radiulogical ana nonradiological impacts are analyzed, including air and water quality, land use, costs, resource requirements, and biological and socioeconomic impacts. 
This environmental document (ED) has been prepared in support of the Department of Energy's (DOE's) Monitored Retrievable Storage (MRS) Program Proposal to Congress. Monitored retrievable storage is temporary storage of commercially generated radioactive spent fuel and high-level waste (HLW). This ED includes a discussion of the purpose of an MRS facility, a description of two facility design concepts, a description of three reference sites, and a discussion and comparison of the impacts associated with each of the six site/concept combinations. Each of these is discussed briefly in this sumary. This analysis is based on a 15,000-MTU (metric tons of uranium) storage capacity and a throughput rate of up to 1,800 MTU per year.

\section{PURPOSE DF AN MRS FACILITY}

The purpose of the MRS facility discussed in this ED is to provide, if needed, temporary federa] storage of commercial, high-tevel radioactive waste and spent nuclear fuel.

Congress recognized the importance of the MRS role to the federal government's conmitment to accept and dispose of comercial nuclear waste by 1998 . In the Nuclear Waste Policy Act of 1982, Congress directs the Secretary of Energy to submit a proposal for construction of one or more MRS facilities, including a plan for integrating MRS facilities with other storage and disposal factlities.

\section{DESCRIPTION OF MRS DESIGN CONCEPTS AND REFERENCE SITES}

The two storage design concepts selected for detailed study are the sealed storage cask and the field drywell. Common to both concepts is the ability to receive and store transportable metal storage casks. The sealed storage cask and the field drywell design concepts have been evaluated for three reference sites: arid, wam wet, and coid wet. A reference site is a hypothetical site that represents general climatic types available in the United States.

For either the seated storage cask or the field drywell concept, the MRS facility is designed for safe, lowrda intenance, temporary storage of commercially generated radioactive wastes. The facility will be secure from public access and will include all necessary support services. At this facility, workers will be able to receive, unload, inspect, decontaminate and/or repackage, prepare for storage, store, monitor, retrieve and ship radioactive wastes. The storage area (for either sealed storage casks or field drywelis) can be expanded as necessary to accommodate the quantities of material requiring storage. When it is no longer needed, the MRS facility can be safely decommissioned.

Waste received at the MRS facility is handled as follows. Shipping casks arrive by truck or by railcar. The casks are unloaded and sent, depending on the contents of the casks, to one of three hot Cells in a receiving and handling (R\&H) facility. All operations in the hot cells are performed remotely. HLW and RHTRU are unloaded from the shipping cask, overpacked if necessary, and offloaded into a storage cask. Spent fuel assemblies are unloaded from the shipping cask and consolidated (disassembled and then packed in a more dense configuration). Sealed canisters of waste are then transported to the storage area. There the canisters are stored either upright in concrete casks (sealed storage cask design concept) or in an array of near-surface drywells in the ground (field dryweli design concept).

Sealed Storage Cask

Sealed storage casks are metal-lined concrete cylinders, closed with shield plugs and welded metal lids, that hold metal canisters of radioactive wastes. They are about 12 feet (3.7 m) in diameter and 22 feet $(6.7 \mathrm{~m}) \mathrm{high}$, weight about 244 tons $(220 \mathrm{MT})$, and stand upright on a concrete pad in a storage field. Heat from radioactive decay is conducted through the sealed storage casks and is dissipated by atmospheric convection and thermal radiation. The reinforced concrete casks and the metal canisters within them shield the radioactive material, keep the surface dose rate to within acceptable limits, and protect the contents from credible human-caused and natural events.

Field Orywell

Field drywells are dry, sealed, metal-lined holes in the ground for storing metal canisters of radioactive wastes. These drywells safely store wastes by using the surrounding soil as both a radiation shield and a conduction path to remove heat from radioactive decay.

The canisters of radioactive material are loaded into or unloaded from the drywells with a shielded transport vehicle that remotely lowers or lifts the canisters. After a canister and shield plug have been

(a) In this document, the simple present and simple future verb tenses are used for ease in describing the MRS facility design concepts and do not imply that an MRS facility will be authorized or built. 
placed into a drywelt, a final drywell cover is welded in place. The drywells are in rows in a field; the tops of the wells are surrounded by concrete, which provides a working surface for the shielded transport vehicle.

\section{Arid Reference Site}

The arid reference $5 i$ te is on a plateau. The climate is semiarid with generaliy mild temperatures, low precipitation and humidity, and a high evaporation rate. Annual average precipitation is about 10.6 inches $(27 \mathrm{~cm})$. The mean annual air temperature is about $59^{\circ} \mathrm{F}\left(15^{\circ} \mathrm{C}\right)$, with extremes of $-31^{\circ} \mathrm{F}\left(-35^{\circ} \mathrm{C}\right)$ to $113^{\circ} \mathrm{F}\left(45^{\circ} \mathrm{C}\right)$.

Warm-Wet Reference Site

The warm-wet reference site is on a plateau. The climate is warm and humid. The surrounding lowland areas are swampy and interspersed with higher upland areas forested by hardwoods and pines. Rainfall averages about 42.5 inches per year $(108 \mathrm{~cm} / \mathrm{yr})$; the mean annual temperature is about $64^{\circ} \mathrm{F}\left(18^{\circ} \mathrm{C}\right)$, with extremes of $5^{\circ} \mathrm{F}\left(-15^{\circ} \mathrm{C}\right)$ to $113^{\circ} \mathrm{F}\left(45^{\circ} \mathrm{C}\right)$.

Cold-wiet Reference Site

The cold-wet reference site is on gently rolling land dedicated largely to row-crop agriculture and interspersed with stands of deciduous trees. The climate is generally cool and wet with a mean annual precipitation of about 35 inches $(89 \mathrm{~cm})$; the mean annual temperature is about $50^{\circ} \mathrm{F}\left(10^{\circ} \mathrm{C}\right)$, with extremes of $-31^{\circ} \mathrm{F}\left(-35^{\circ} \mathrm{C}\right)$ to $113^{\circ} \mathrm{F}\left(45^{\circ} \mathrm{C}\right)$.

\section{IMPACTS ASSOCIATED WITH SITE/CONCEPT COMBINATIONS}

This section sumarizes the environmental impacts of an MRS facility and compares the impacts to existing environmental regulations. Most impacts vary only slightly or even negligibly among the three reference sites; exceptions to this are noted.

Radiological impacts, in terms of doses to the public, are very low. Population doses from operations and from transportation to and from an MRS are estimated to be less than 1.3\% of the naturally occurring background radiation for all site/concept combinations. The worst-case design basis accident (which would result in the highest dose to an individual) would result in less than 1 or of the regulatory limit for design basis accidents (10 CFR 72). This postulated accident is a diesel fuel fire associated with the sedied storage cask concept at the arid reference site. Design basis accidents for all other site/concept combinations are estimated to result in a dose of less than $0.5 \%$ of the regulatory 1 imit. When transport of spent fuel and wastes both to and from the MRS facility are considered, transportation impacts are comparable for all site/concept combinations. This result is based on a bounding analysis that does not consider reduced numbers of shipments caused by fuel consolidation. If consolidation were included in the analysis, the impacts would be more dependent on site location (shown by Holter and Braitman 1985); then the transportation impacts would be roughly proportional to the total shipment miles.

The MRS would have only a negligible effect on air quality. The largest impact identified, which is dust generation during construction, would be below federal ambient standards even for the dustiest site (arid).

The quality of surface water and ground water would not be significantly affected by an MRS. The water required for cooling in the receiving and handling facility could preclude the siting of an MRS in sone arid sites where water use is restricted.

Up to 350 acres of Tand is required for a 15,000-MTV MRS facility. Construction activities would destroy vegetation and existing habitats for some small animals, birds and insects. These impacts are larger in the warm-wet and cold-wet sites because of the generally higher population of organisms; however, revegetation would occur more quickly at the wet sites because of climate.

Socioeconomic impacts depend on the size and the character of an economy into which the MRS is introduced much more than they depend on the site/concept combination. Therefore, the socioeconomic impacts of siting an MRS at any specific arid, cold-wet or warm-wet site cannot confidently be projected with the reference-site approach of this report. However, to provide a basis for estimating potential impacts of an MRS, baseline values for regional population, employment and income were designated for each of the three reference sites. An extensive analysis using computer models (described in Appendix C) identified these general trends:

- The size of the comunity and the size of its regional economy affect the economic impacts of an MRS. Large mutiplier effects assocjated with larger regional econonies tend to increase absolute economic impacts for those larger economies. However, the percentage of change from baseline values is still iikely to be smaller for larger economies. 
- Two factors other than size of the community also affect economic impacts: availability of properly trained labor and the role an economy plays in relation to the surrounding region.

- A sparsely populated area is mure likely to be required to substantialiy increase its public service base to absorb the MRS facility impacts.

- This reference site analysis indicated that population changes and housing demands are below the threshold at which adverse socioeconomic impacts typically occur. However, this result could not be confidently generalized to apply to every real cancidate site. Such a site would have to be examined in more detail.

- Public revenues and expenditures would be impacted by an MRS, but the direction and size of net impacts on local and state government cannot be projected in a reference-site analysis. However, this analysis does show that in some cases revenue increases could exceed expenditures, resulting in a net public sector benefit.

The resources required to construct and operate an MRS are abundant in the United States. The present value of construction, operation, and decomissioning costs for the MRS facility is estimated to be approximately $\$ 1$ bilition. The cost does not vary significantiy among the site/concept combinations. About 400 to 700 workers would be employed during each year of construction. An average of 400 workers would be employed during each of the 25 years of operation.

\section{COMPARISON OF IMPACTS}

This section summarizes whether and how environmental impacts vary significantly among the six site/ concept combinations.

Radiologicat impacts for operation, transportation, and postulated accidents are well below regulatory limits and do not vary significantly among site/concept combinations. Since doses from transportation are related to the number of shipnent miles, a site that results in reduced total shipment miles could alluw a proportionate reduction in transportation-related dose depending on population densities along the route.

The greatest air quality impact is expected to be from dust emissions during construction; the arid site is the dustiest. Water quality impacts should be minimal; however, water requirements for cooling in the R\&H facility could preciude siting of an MRS in some arid sites where water use is restricted. Biological impacts are similar in nature but vary in magnitude. Resource requirements do not vary signifi. cantly among site/concept combinations. Costs vary up to about $10_{\%}^{\circ}$ among the six combinations; this is not considered significant.

For this reference-site analysis, socioeconomic impacts are more dependent on the site characteristics than on the storage design concept. Further site-specific information would be required to project socioeconomic impacts of an MRS at a particular site.

\section{ADDITIONAL INFORMATION}

Also included in this environmental document are:

- a list of abbreviations

- a glossary of terms

- appendices on:

- storage concepts not selectea for detailed study

- environmental impact analysís

- socioeconomic models and assumptions. 


\section{CONTENTS}

PREFACE

SUMMARY

PURPOSE OF AN MRS FACILITY

DESCRIPTION OF MRS DESIGN CONCEPTS ANO REFERENCE SITES

Sealed Storage Cask.

Field Orywell

Arid Reference Site.

Warm-Wet Reference Site

Cold-Wet Reference Site

IMPACTS ASSOCIATED WITH SITE/CONCEPT COMBINATIONS .

COMPARISON OF IMPACTS

ADOITIONAL INFORMATION

LIST OF ABBREVIATIONS

CONVERSION TABLE

1.0 PURPOSE OF AN MRS FACILITY

2.0 OESCRIPTION OF MRS FACILITY DESIGN CONCEPTS

2.1 MRS FACILITY PACKAGING AREA

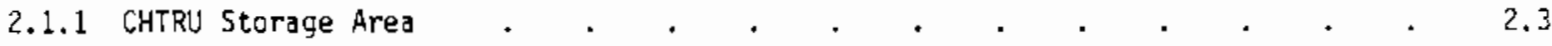

2.1.2 Receiving and Handling Facility for Spent Fuel, HLW and RHTRU . . . . 2.3

2.2 MRS FACILITY STORAGE AREA FOR SPENT FIJEL, HLW AND RHTRU . . . . . . . . . . 2.5

2.2.1 Sealed Storage Cask Design Concept . . . . . . . . . . . . . . . . . . . 2.6

2.2.2 Field Drywell Design Concept . . . . . . . . . . . . . . . . . 2.7

2.3 PROVISTONS FOR EXPANSION, EXTENDED STORAGE, ANO DECOMMISSIONING . . . . . . . . 2.7

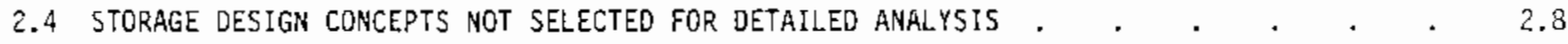

3.0 REFERENCE-SITE DESCRIPTIONS

4.0 IMPACTS ASSOCIATED WITH SITE/CONCEPT COMBINATIONS . . . . . . . . . . . . . 4.1

4.1 RADIOLOGICAL IMPACTS

4.1.1 Construction Activities

4.1.2 Operation Activities

4.1.3 Operating Accidents

4.1.4 Decommissioning Activities

4.1.5 Transportation Activities

4.1.6 Cumulative Effects

4.1.7 Summary.

4.2 AIR QUALITY IMPACTS

4.2.1 Construction Activities

4.2.2 Operation Activities

4.2.3 Decormissioning Activities

4.2.4 Transportation Activities

4.2.5 Summary.

4.3 WATER QUALITY AND USE IMPACTS .

4.3.1 Construction Activities

4.3.2 Operation Activities

4.3.3 Decommissioning Activities

4.3.4 Transportation Activities 
4.3 .5 Sumary . . . . . . . . . . . . . . . . . . . . . . . . . 4.15

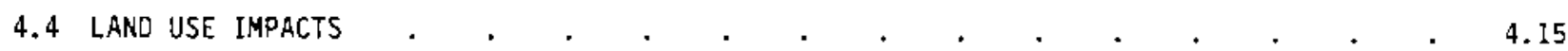

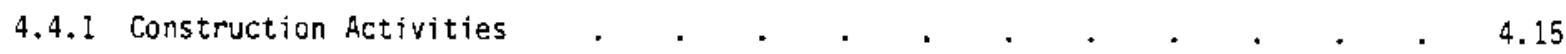

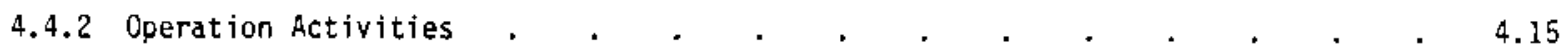

4.4 .3 Decommissioning Activities . . . . . . . . . . . . . . . . . . . . . . 4.16

4.4 .4 Summary. . . . . . . . . . . . . . . . . . . . . 4.16

4.5 BIOLOGICAL IMPACTS . . . . . . . . . . . . . . . . . . . . . . . . . . . . . . . . . . . . . . . . .

4.5 .1 Construction Activities . . . . . . . . . . . . . . . . . . . . . . . . . . . . . . . .

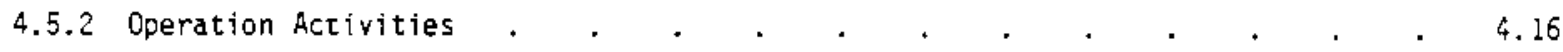

4.5 .3 Decomissioning Activities. . . . . . . . . . . . . 4.17

4.5.4 Transportation Activities . . . . . . . . . . . . . . . . . . . . . . . . . . . . . .

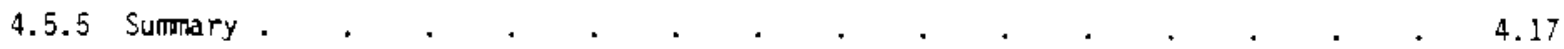

4.6 SOCIOECONOMIC IMPACTS . . . . . . . . . . . . . . . . . . . . . 4.17

4.6.1 Employment and Income. . . . . . . . . . . . . . . . . . . . . . . . . . . . . . . . . .

4.6.2 Population and Housing. . . . . . . . . . . . . . . . . . . . . . 4.21

4.6.3 Public Revenues and Pubitic Service Expenditures. . . . . . . . 4.24

4.6.4 Special Nuclear-Related Socioeconomic Effects . . . . . . . . . . . 4.30

4.6 .5 Summary. . . . . . . . . . . . . . . . . . . . . . . . 4.31

4.7 RESOURCE REQUIREMENTS AND COST IMPACTS . . . . . . . . . . . . . . . . . 4.31

4.7.1 Construction Activities . . . . . . . . . . . . . . . . . . . . . . . . . . . . . . .

4.7.2 Operation Activities . . . . . . . . . . . . . . . . . . . . . . . . . . . . . . . . . . . . . . . . . .

4.7.3 Decomissioning Activities . . . . . . . . . . . . . . . . . . 4.34

4.7.4 Transportation Activities . . . . . . . . . . . . . 4.34

4.7 .5 Fiscal Costs. . . . . . . . . . . . . . . . . . . . . . . . . . . . . . . .

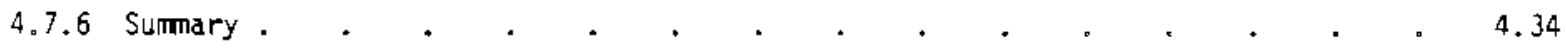

5.0 COMPARISON OF IMPACTS . . . . . . . . . . . . . . . . . . . . . . . . . . . . . . . .

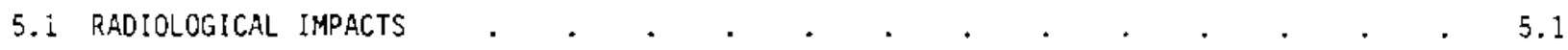

5.1 .1 Operation Activities . . . . . . . . . . . . . . . . . . . . . 5.1

5.1 .2 0perating Accidents . . . . . . . . . . . . . . . . . 5.2

5.1 .3 Transportation Activities . . . . . . . . . . . . . . . 5.2

5.2 Air quality IMPACTS . . . . . . . . . . . . . . . . . . . . . 5.2

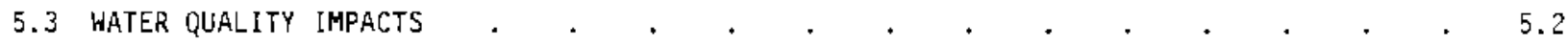

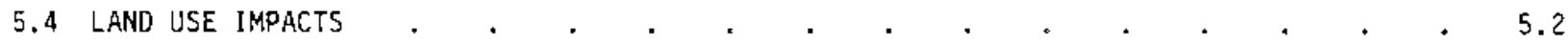

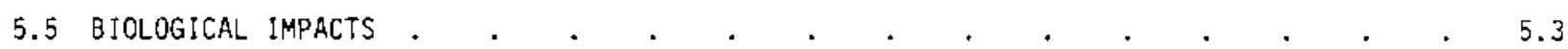

5.6 SOCIOECONOMIC IMPACTS . . . . . . . . . . . . . . . . . . . . . . . . . . . 5.3

5.6.1 Employment and Income . . . . . . . . . . . . . . . . . . . . 5.3

5.6 .2 Population and Housing. . . . . . . . . . . . . . . . . . . . . . 5.4

5.6.3 Public Revenues and Public Service Expenditures. . . . . . . . . 5.5

5.7 RESOURCE REQUIREMENTS AND COST IMPACTS . . . . . . . . . . . . . . . . . . 5.5

REFERENCES

GLOSSARY OF TERMS

APPENDIX A - STORAGE DESIGN CONCEPTS NOT SELECTED FOR DETAILED ANALYSIS

Ref.1

GL.1

APPENDIX B - ENYIRONMENTAL IMPACT ANALYSIS

APPENDIX C - SOCIOECONOMIC MODELS AND ASSUMPTIONS . . . . . . . . . . . . . . . C.I 
2.1 Monitored Retrievable Storage Facility.

2.2 Receiving and Handing Operations.

2.3 Sealed Storage Casks

2.4 Field Drywelis

4.1 Total Employment Impacts of a Sealed Storage Cask Facility by Site

4.2 Total Employment Impacts of a Sealed Storage Cask Facility

Versus a Field Drywell Facility, Cold-Wet Site

\section{TABLES}

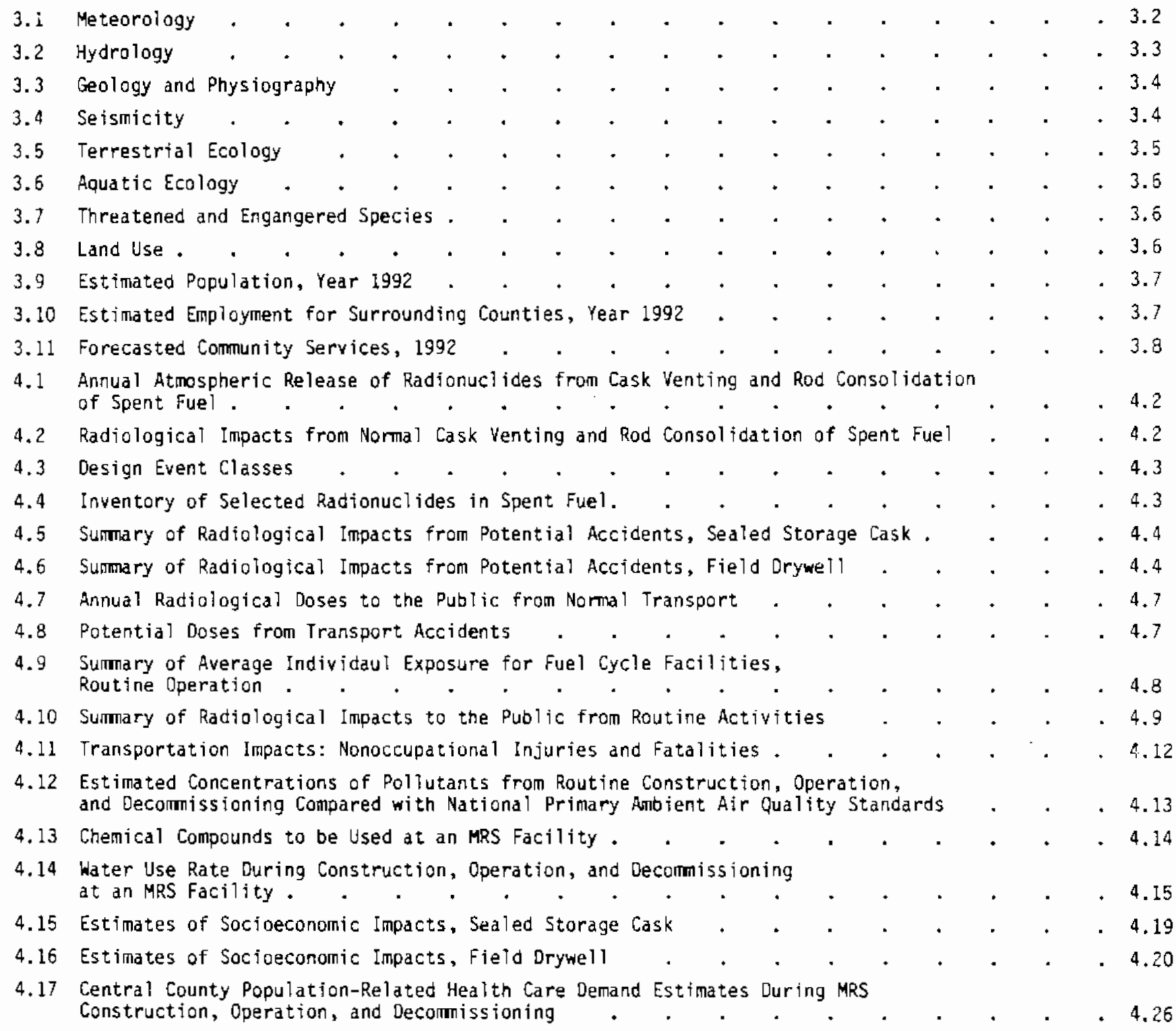


4.18 Population-Related Daily Consumption for Central County Utility Systems

During MRS Peak Construction, Operation, and Decomissioning . . . . . . . 4.30

4.19 Resource Requirements for a 15,000 MTU MRS Facility, Sealed Storage Cask . . . . . 4.32

4.20 Resource Requirements for a 15,000 KTU MRS Facility, Field Dryweli . . . . . . . 4.32

4.21 Present Value Cost Estimates for Construction, Operation, and Decomissioning,

Sealed Storage Cask. . . . . . . . . . . . . . . . . 4.33

4.22 Present Value Cost Estimates for Construction, Operation, and Cecomissioning, . . . . . . . . . . . . . . . . . . . . . . . . . . . . .
Field Drywell.

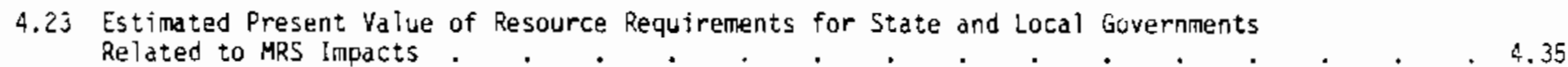

5.1 Sumary of Radiological Impacts from an HRS Facility . . . . . . . . . . . . . 5.1

5.2 Relationship of MRS Regional Employment and Income Impacts to Baseline

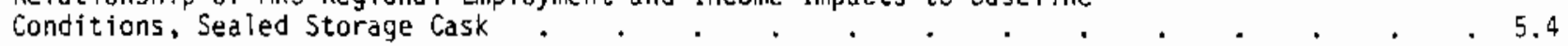

5.3 Relationship of MRS Regional Employment and Income Impacts to

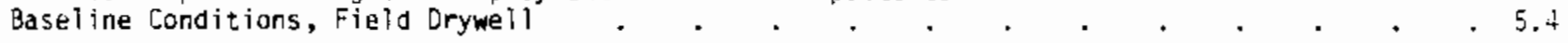

5.4 Relationship of MRS Population and Housing Demand Impacts to Baseline Conditions,

5.5 Relationship of MRS Population and Housing Demand Impacts to Baseline Conditions, . . . 5.7 


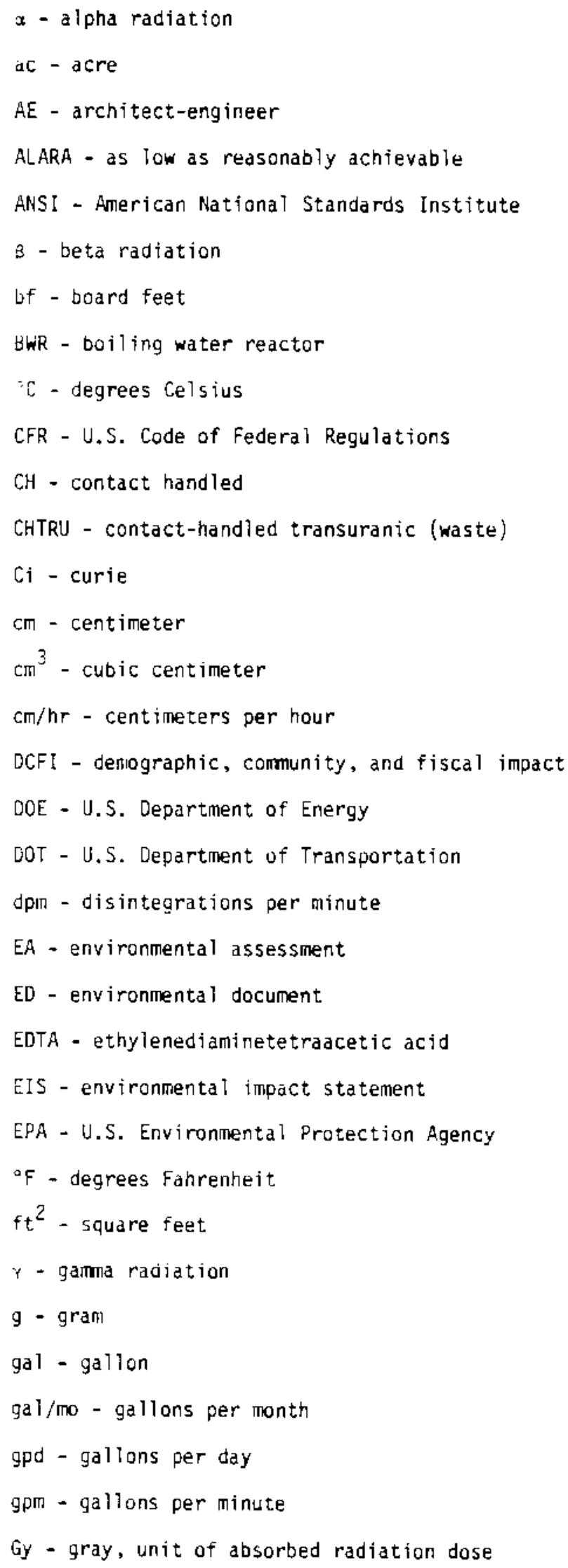




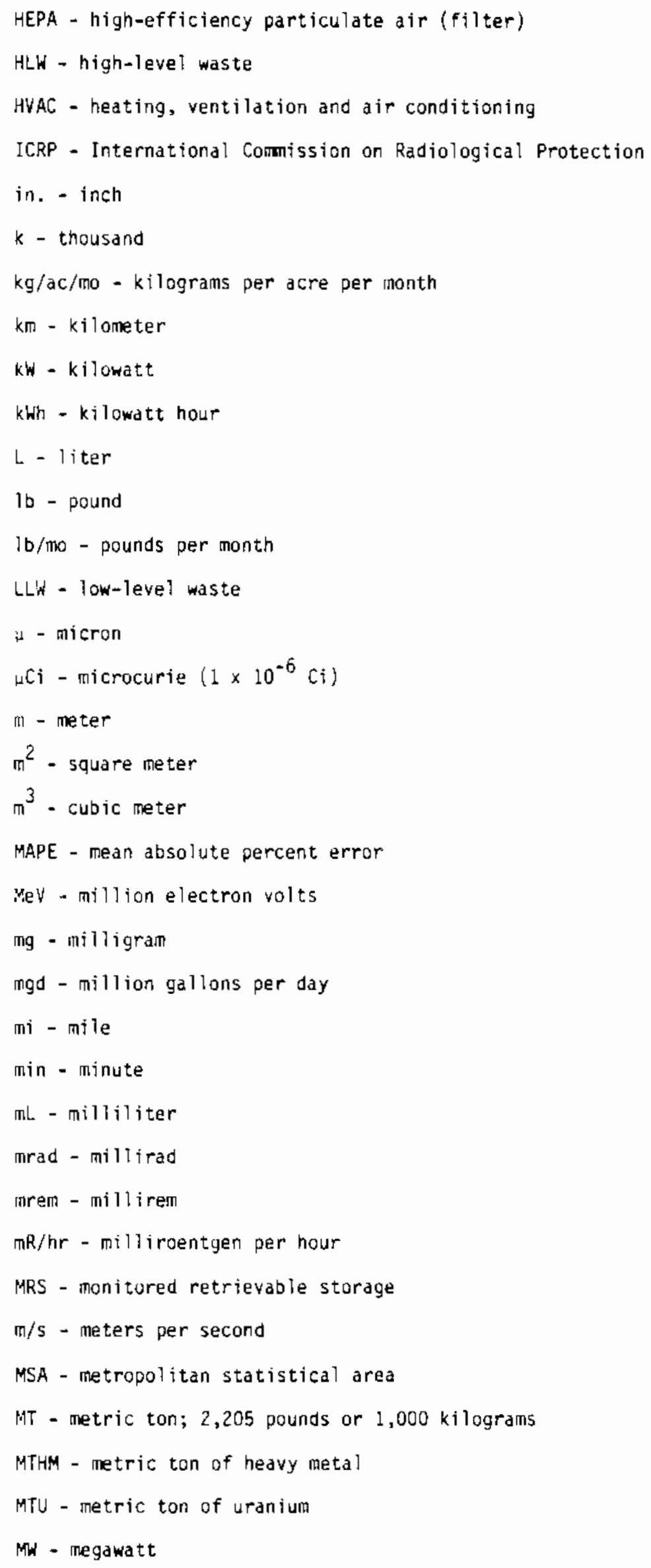




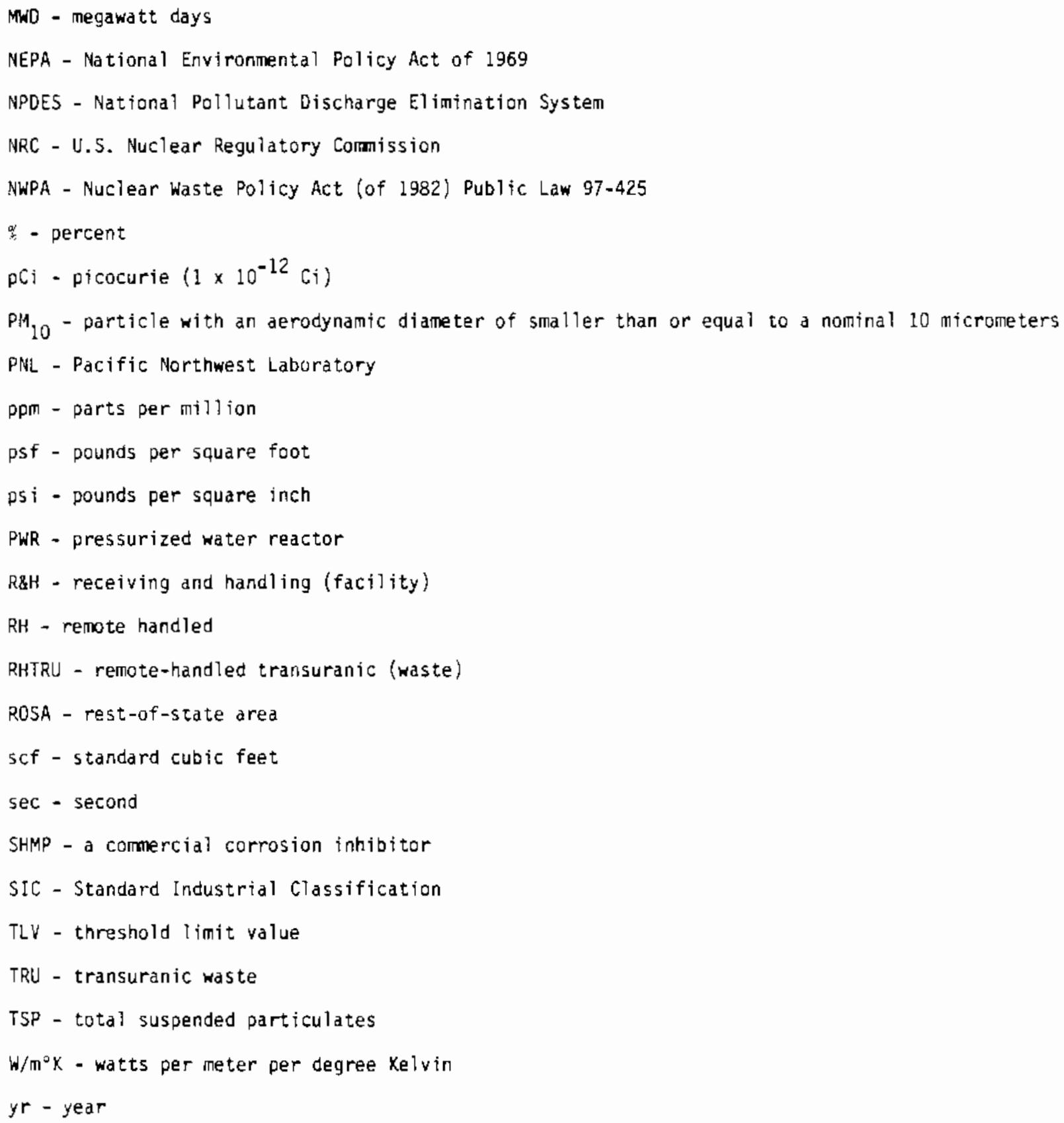

$$
\begin{aligned}
& \mathrm{in} \times 2.54=\mathrm{cm} \\
& \mathrm{kg} \times 2.205=1 \mathrm{~b} \\
& \mathrm{kn} \times 0.621=\mathrm{mi} \\
& \mathrm{km}^{2} \times 0.386=\mathrm{mi}^{2} \\
& \mathrm{~L} \times 0.264=\mathrm{gal} \\
& 1 \mathrm{~b} \times 0.454=\mathrm{kg} \\
& \mathrm{m} \times 3.281=\mathrm{ft} \\
& \mathrm{m}^{2} \times 10.76=\mathrm{ft}^{2} \\
& \mathrm{~m}^{3} \times 35.31=\mathrm{ft}^{3} \\
& \mathrm{mi}^{2} \times 1.609=\mathrm{km}^{2} \\
& \mathrm{mi}^{2} \times 2.59=\mathrm{km}^{2}
\end{aligned}
$$


4

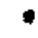




\subsection{PURPOSE OF AN MRS FACILITY}

The purpose of the monitored retrievable storage (MRS) facility discussed in this ED is to provide, if needed, temporary federal storage of commercial spent nuclear fuel and high-ievel radioactive waste.

The Nuclear Waste Policy Act (NWPA) of 1982 states that the Secretary of Energy is to complete a detailed study of the need for and feasibility of MRS facilities and submit to Congress a proposal for construction of one or more MRS facilities for storage of spent nuclear fuel and high-level radioactive waste. The Secretary of Energy is also directed to inciude a plan for integrating MRS facilities with other storage and disposat facilities authorized by the NWPA [Section 14](b)(2)(D)].

In carrying out these requirements, the DOE has considered alternative roies and schedules for MRS facilities and has assessed their value to the federal waste management system. The DoE has evaluated 1) a backup MRS facility to be constructed cniy if there is a significant delay in the repository system ano 2) an integral MRS facility to receive, prepare, package and temporarily sture spent fuel for subsequent oisposal at the repository. The information in this ED is for a backup MRS facility capabie of handling 1800 mitu per year.

The MRS facility must be designed to:

- accormodate spent nuclear fuel and high-level radioactive waste resulting from civilian nuclear power activities

- pemit continuous monitoring, management, and maintenance of such fuel and waste for the foreseeable future

- provide for the ready retrieval of such fuel and waste for further processing or dispusal

- safely store such fuel and waste as long as may be necessary by maintaining the facility through appropriate means, incluoing any facility replacements. 


\subsection{DESCRIPTION OF HRS FACILITY OESIGN CONCEPTS}

An important consideration in the design of an MRS facility and in the selection of appropriate storage concepts is that the HRS system should not constrain the operation of the total waste management system. Rather, the MRS system should be an integrated component of the total system (including at-reactor storage, transportation, and repositories) (DOE 1984b).

Selection of Storage Design Concepts. During the past 15 years, numerous spent fuel and high-leve waste (HLW) storage concepts have been extensively studied in the United States and in foreign countries. These studies indicate that technologies for passive, dry storage are preferred for long-term storage applications. This work has included development, demonstration, and evaluation of storage facitities anc systems. In developirig the MRS program, the DOE has continued to pursue these passive, dry storage technologies to mininize the dependence of sturage safety on active components.

The DOE recently conducted screenings and evaluations of potential MRS concepts and concluded that the following concepts could be engineered to meet the MIRS requirements:

casks: metal storage casks concrete casks (sealed storage casks) concrete casks in trench (or berm)

drywells: $\quad$ surface field drywells tunnel drywells

vaults: $\quad$ surface, open-cycle vaults surface, closed-cycle vaults subsurface, open-cycle vaults (tunnel rack).

However, the technological maturity, flexibility, cost, environmental impacts, siting requirements, sucioeconomic impacts, and safety and licensing concerns vary among the eight concepts. These factors were considered by DOE in selecting the sealed storage cask (concrete cask) and field drywell concepts for the MRS designs (DOE 1984b). Both design concepts are compatible with a transportable metal storage cask that could be used at utility sites, if needed, and later transferred to an MRS.

Assumptions. The basic assumptions usea for both the MRS facjlity design concepts and for the impacts est imated in this envirunmental docurient are:

- 40-year facility design lifetime that can be extended in 20-year increments

- 25-year operating lifetime for the socioeconomic impact evaluation

- 1,800 metric tons of uranium (MTU) per year facility throughput rate

- 15,000 MTU storage capacity

- type of waste: primarily spent fuel (60\% pressurized water reactor (PWR) and 40\% boiling water reactor (BWR) by weight) and a small amount ( $220 \mathrm{MTU} /$ year equivalent) of high-level waste

- age of waste: $95 \%$ is ten years old; $5 \%$ is five years old and/or is 10 -year-old spent fuel with a high burnup (up to 55,000 megawatt days (MWD)/MTU)

- spent fuel consolidated as follows (maximum)

- 3 PWR assemblies/canister

- 7 BHR assemblies/canister

- for bounding, transportation is calculated both as $100 \%$ by truck ana $100 \%$ by rail.

Facility Design. The MRS facility is designed for safe low-maintenance storage of radioactive wastes, including spent nucTear fuel, high-level waste ( $H L W$ ), apd, transuranic waste (TRU) (both remote handled (RH) and contact handled (CH)). The facility will be secure from public access and will include all necessary support services to accomplish safe waste handling and storage. Workers will be able to receive, by either truck or railcar, containers of conmercially produced radioactive wastes and unload, inspect, decontaminate and/or repackage, prepare for storage, store and monitor those wastes. The facility will be able to receive, handle, and store transportable metal storage casks. When necessary, the stored wastes will

(a) In this document, the simple present and simple future verb tenses are used for ease in describing the IARS facility design concepts and do not imply that an MRS facility will be authorized or built. 
be easily retrieved from storage and shipped off site. At this facility, the storage capacity can be expanded as necessary to accomodate the quantities of material requiring storage, ana the wastes can be safely stored for as long as necessary. When the MRS facility is no longer needed, it can be safely decomissioned.

To qualify for licensing by the NRC (20-year license, renewable), the MRS facility is designed to meet all applicable federal regulations. Its design lifetime is 40 years, and that lifetime can be extended in 20 -year increments. For this ED, an actual operating iffe of 25 years is assumed. The facility would receive waste for about a third of the 25 years. The MRS facility will be capable of being repaired and expanded as required.

The MRS facility as designed has three areas: a packaging area, a storage area, ana a support services area. For this ED, two storage area design concepts are considered, the sealed scorage cask and the field drywell, because they most closely satisfy the criteria of the Hiks mission (Triplett and Sinith 1984). Storage design concepts that were not chosen for these design studies are listed at ihe end of this chapter and briefly described in Appendix A.

The general waste handling sequence is as follows. Shipping casks arrive at the inspection gate house, where they receive a clearance to enter the receiving and handling (RaH) facility. The railcars or truck trailers are washed. Each cask is removed from its vehicle and loaded onto cask carts. Casks go to one of three hot cells, depending on the cask contents. In one cell, casks containing canisters of HLW or drums of RHTRU are overpacked if necessary and then offloaded into a storage cask. The other two cells are for spent fuel. In these cells spent fuel assembies are inspected, identified, disassembled, consolidated (fuel rods are packaged in canisters in a more dense configuration), seal-welded, ultrasonicaliy inspected, and decontaminated. Non-fuel-bearing components (such as fuel assembly grids and skeletons) are compacted by shredding. Orums of the compacted waste are offloaded into storage casks.

Packaged waste from any of the three cells is then transferred to onsite storage. For the sealed storage cask concept, packaged waste is loaded into a concrete cask and transported out to the storage area of the facility. The cask is stored upright on a concrete pad. For the fiela orywell concept, packaged waste is loaded from the cell into a transport shield. A transport vehicle then moves the shielded waste out to the storage area and lowers it into a near-surface drywell. A shield piug is placed over the canister in the drywell. Finally, an adjitional cover is placed on the drywell top (at the grabnd surface level).

These designs provide for both isolation of the waste from the environinent and retrieval of the waste for shipment to a repository. A more detailed description of the MRS facility follows.

All persons, vehicles, equipment and materials entering and leaving the MRS facility coritrolled area witl be munitoreci, and unauthorized persons or vehicles will be denied entry. The MRS facility site boundary will oe surrounded by a fence. In addition, the controlled area of the tacility will be entirely contained inside an 8-foot-high security fence, with two levels of security, a limited access area and a protected area. The limited access area contains the facility support services. The protected area must be entered through the limited access area and has an extra fence, guards, surveillance devices, and an alarm system for added security.

All radioactive wastes will be handled and stored in the protected area to ensure that orily qualified personnel will be near the radioactive materials and that members of the public will be protected frum any possible exposure to the wastes. Figure 2.1 is a drawing of the MRS facility showing the three facility areas: support services, packaging, and storage; and the two security levels: linited access and protected.

The storage areas and all operations in the facility will be monitored for radiation to verify that conditions do not exist that could unnecessarily expose workers or the public to radioactive inaterials. The environment of the facility and the surrounding area, all personnel, and cask or drywell storage areas will be monitored. Environmental monitoring will include measurements at fixed monitoring posts and analyses of samples of air, dust, water, and soil gathered pericdically. Personnel pionitoring will include personnel dosimeters and hand and foot monitors. Cask and arywell containment will be monitored by gas samples from the area around the lid seals and from the internal cavity of the casks or drywells.

The support services and packaging areas of the overall facility are nearly the same for bath storacge concepts. These common areas will be described first, followed by a description of the two alternative storage area design concepts.

The support services area includes: administration building, site services building, supplies warehouse, vehicle maintenance building, security building, inspection gatehcuse, main gate badgehouse, fire station, heliport (for possibie medical evacuations in remote site areas), water treatment facility, water storage, sewage treatment facility, fuel tanks, and punip station. These support services are colnon to many types of facilities and are not described in detai] here. 


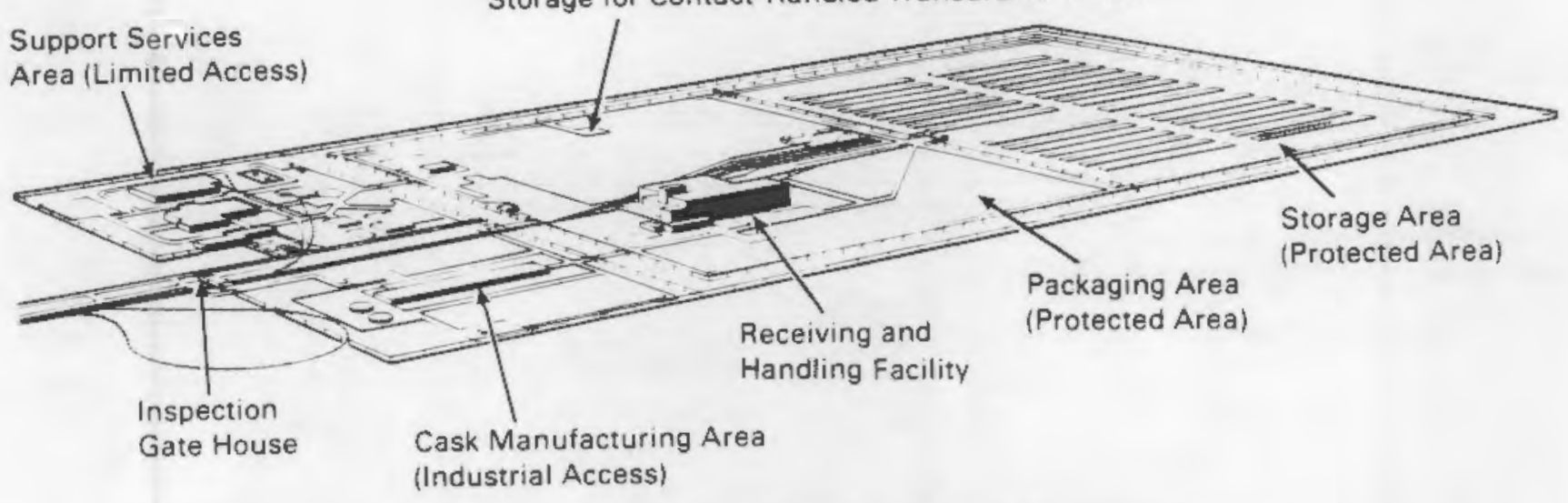

FIGURE 2.1. Monitored Retrievable Storage Facility

\subsection{MRS FACILITY PACKAGING AREA}

In the packaging area are the storage area for CHTRU; the R\&H facility for spent fuel, HLW, and RHTRU; the main electrical substation; the building that houses the standby generator (for safe operation of necessary activities if normal power is lost); the protected area gate house; and the area for temporarily holding shipments of radioactive waste materials (isolation area for railcars and trucks that arrive with insufficient paperwork, etc.). The CHTRU storage area and the R\&H facility designs are described below.

\subsubsection{CHTRU Storage Area}

Contact-handled transuranic waste is stored in a separate area because of its low level of beta-gamma radioactivity, which requires less additional shielding than the other waste types stored at the MRS facility. The radiation dose rate at the surface of the container is used to designate whether a package is contact handled or remote handled.

Low-level waste generated from MRS facility operation will be packaged in the R\&H facility for longterm storage in the CHTRU storage area. The storage area is made up of vaults of reinforced concrete designed to withstand credible natural events. These vauits are concrete-iined pits in the ground, containing stacks of waste drums and covered with thick concrete lids. When one vault is full, another can be prepared as needed. No ventilation is necessary in the vaults, and each is equipped with a capped pipe to allow gas sampling and other monitoring. The vaults are equipped with sumps and arains so that any moisture that might accumulate within the dry vaults can be monitored for radioactive contamination.

\subsubsection{Receiving and Handling Facility for Spent Fuel, HLW and RHTRU}

The R\&H facility is the main packaging area at the MRS facility. It is the same for both the sealed storage cask and the field drywell storage concepts, except for the canister discharge capabilities particular to the storage concept.

The R\&H facility is an environmentally controlled structure designed to prevent exposure of the public and of the operating personnel to radiation doses in excess of regulatory limits. The entire structure is monolithic, poured-in-place concrete with sealed joints, air-controlled entries, and a ventilation system designed to maintain a negative air pressure (with respect to atmospheric pressure) within the building.

The R\&H facility (see Figure 2.2) is designed to accept rail- and truck-mounted shipping casks and to unload and repackage (if necessary) their contents (canisters of spent fuel, HLW, or RHTRU canisters). After repackaging into canisters, the wastes are loaded into a sealed storage cask or a shielded transport vehicle (for transfer to field drywells) at the discharge port. For HLW and RHTRU, the items discharged are the same as those received except that some of the units may have been repackaged or repaired because of damage during shipment. The spent fuel will be disassembled, consolidated ano sealed in canisters before discharge into the casks.

Besides having offices, change rooms, lab areas, etc., the R\&H facility has several handing areas where most operations are perfonmed remotely so that workers are protected from direct exposure to radioactive materials. The workers observe the automated processes and can operate ario/or interrupt the handling machines from shielded operating galleries. The handling areas consist of cask receiving and handling, hot-cell operations, and transfer/discharge of packaged wastes. 


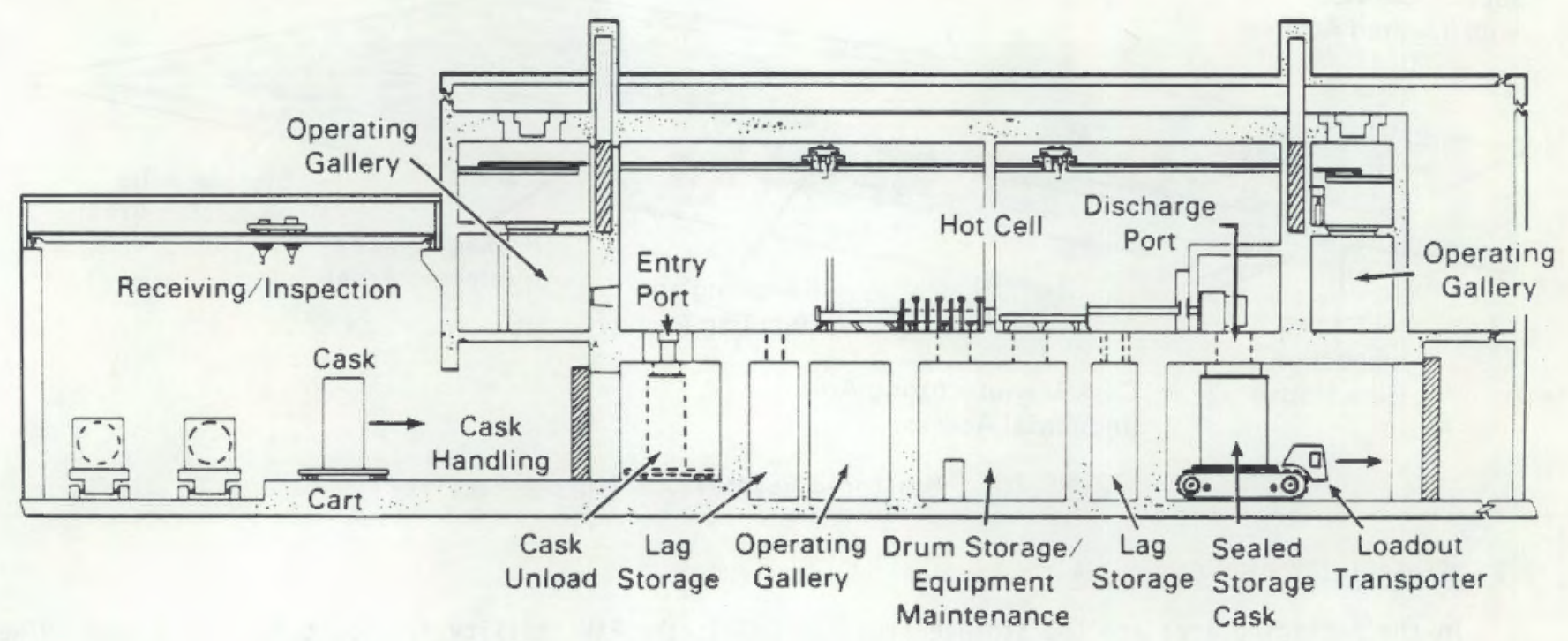

FIGURE 2.2. Receiving and Handling Operations

In the railcar or truck cask handling area, the casks are checked for contamination, and the transport vehicles are cleaned of road grime, snow and ice at a washdown station. Then each cask vehicle is moved to a receiving and preparation area, where the cask is lifted from the railcar or truck and placed on a cart, which travels along rail tracks perpendicular to the incoming rail tracks. The cask cart is moved to the cask unloading room where the cask is vented and the contents of the cask are verified and unloaded through the entry port into a hot cell.

Hot cells are enclosed areas with thick concrete walls and sophisticated ventilation systems that capture and contain airborne particulate radioactivity. The operating floor of the hot cells is above the cask cart rail tracks, permitting upward access from the upright shipping casks through the inlet ports into the hot cell. Workers in the shielded operating galleries on the hot-cell floor level supervise all processing in the hot cells. The hot cells are divided into "clean" and "contaminated" areas by a confinement barrier. The disassembly and consolidation equipment is in the "contaminated" area of the cell. The welding, inspection, and decontamination equipment is in the "clean" area. Lag storage areas, for temporary storage of materials that are in some stage of the packaging sequence, are provided in both areas of the hot cell.

Spent fuel will be disassembled in the hot cells. The fuel rods, which contain radioactive materials (nuclear fuel), will be separated from the control mechanisms, nozzles, spacers, end plates, etc. The fuel rods from PWR or BWR assemblies can be consolidated in one canister ( 3 PWR/canister or 7 BWR/canister maximum). The non-fuel-bearing components of the spent fuel assemblies can be volume reduced and packaged in drums.

Hot-cell processing equipment can also place intact spent fuel assemblies into canisters. There will be equipment to handle canistered fuel, either intact or consolidated, canisters of HLW and RHTRU, and drums of incoming RHTRU.

The transfer/discharge area is below the hot-cell operating floor. This permits downloading of canisters through the discharge port into a storage cask (or shielded transporter) for transfer out of the R\&H facility.

The sealed storage cask will be loaded from the top with the cask transporter positioned under the R\&H facility discharge port. The transfer area that leads to the discharge port will be of sufficient size to accomodate the cask transporter with cask (i.e., 28 feet $(8.5 \mathrm{~m}$ ) high by 24 feet $(7.3 \mathrm{~m})$ wide). The transporter will follow positioning marks on the floor to the discharge port, it will stop directly under the port, and the port interface and shielding collar will be lowered to the cask top surface. Seals are established at the collar and cask interface and at the collar and hot-cell floor interface. With the cask in position and the seals established, the cask is loaded in this sequence: 
- hot-cell port plug removed into hot cell

- cask shield plug removed into hot cell

- canisters loaded

- cask shield plug replaced

- hot-cell port plug replaced

- cask moved to transfer area

- metal cask lid welded into place

- cask inspected and released for storage.

Then the sealed storage cask is transferred to $i$ ts place on the concrete pad in the storage area (see Figure 2.3).

For field drywell storage, the canisters of prepared wastes are loaded down from the hot cell into a shielded transporter (instead of the concrete cask) for transfer to a drywell. The transporter is positioned over the drywell, shielding seals the interfaces, and the canister and drywell shield plug are lowered into the drywel1. The transporter is moved, and the top of the drywell liner is welded shut (see Figure 2.4).

\subsection{MRS FACILITY STORAGE AREA FOR SPENT FUEL, HLW AND RHTRU}

The third main area of the MRS facility is the storage area for the spent fuel, HLW and RHTRU after they have been processed in the R\&H facility. The configuration of the storage area and the type of containment depend on the storage concept. Sections 2.2.1 and 2.2.2 are descriptions of the storage areas for the sealed storage cask and the field drywell concepts.

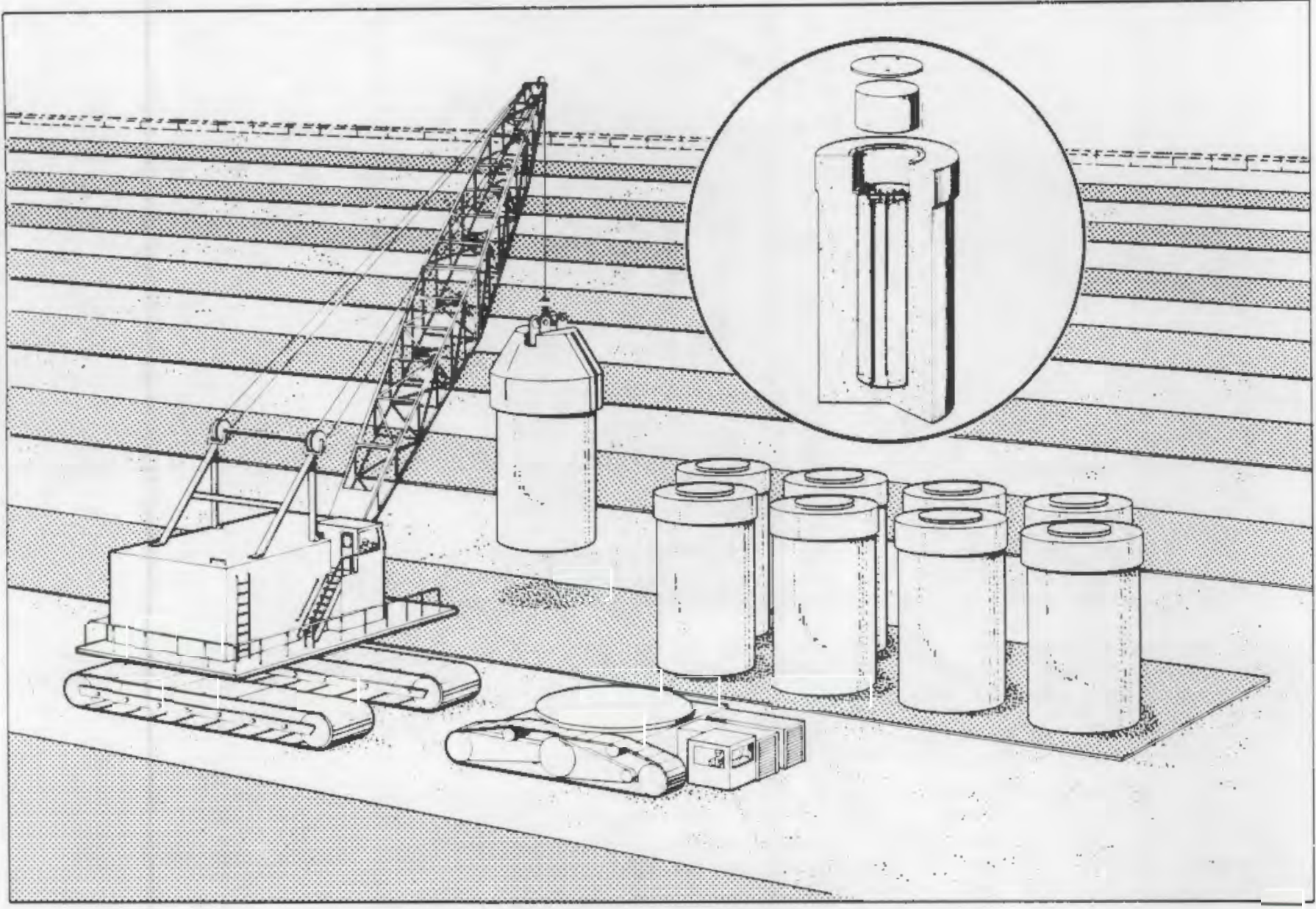

FIGURE 2.3. Sealed Storage Casks 


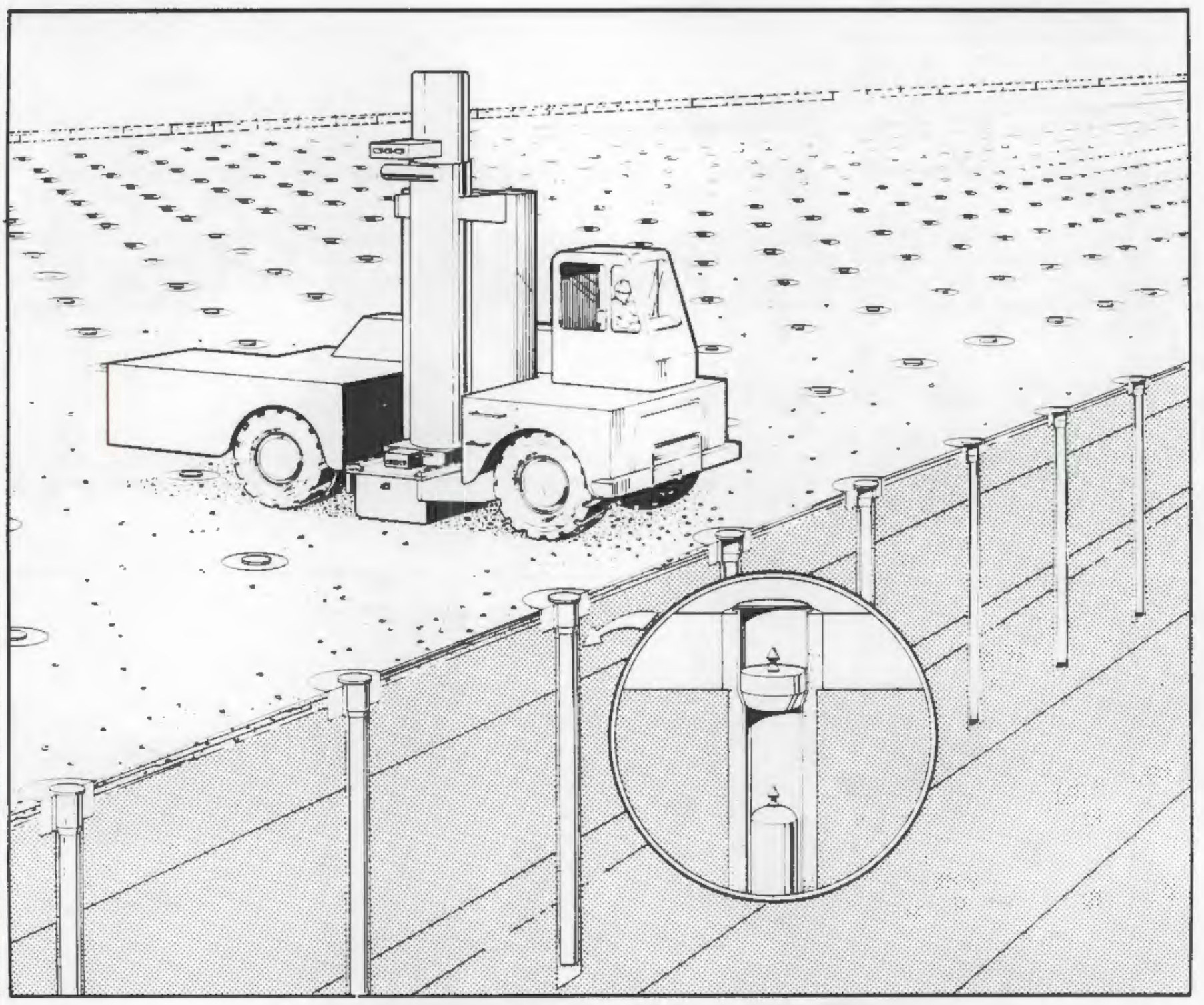

FIGURE 2.4. Field Drywells

In both the sealed storage cask and field drywell storage areas, it will be possibie to accept, handie, prepare for storage, store, and retrieve transportable metal storage casks. These cylindrical casks will be stored on their sides on cuncrete "saddles" on a concreze pad.

The sealed storage casks, field drywells, and transportable metal storage casks are all designed to be monitored for breach of containment of their radioactive contents. The individual storage contalners will be monitored regularly for possible loss of integrity.

\subsubsection{Sealed Storage Cask Design Cuncept}

The sealed storage cask is a steel-lined, reinforced concrete cylinder (cask) that can contain canisters of spent fuel, KLW, or RHTRU. Heat from radioactive decay is conducted through the concrete cylinder and removed at the surface by atmospheric convection and thermal radiation. The reinforced concrete cask provides stielding that keeps the surface radiation dose rate within acceptable limits. The concrete casks and the metal canisters within them provide double barrier containilent of the wastes.

At the R\&H discharge port, the spent fuel, HLW, or RHTRU waste canisters/drums are placed into the metal-lined cask, and a concrete shield plug is installed. An outer metal lid is welded to the cask liner while the cask is in the transfer area. The cask is then transported to the storage yard by a motorized vehicle. 
The storage area is composed of a series of concrete support pads separated by roadways that are used by an emplacement crane and a cask transporter. The cask support pads are about 40 feet (12.2 m) wide by 520 feet $(158.5 \mathrm{~m})$ long and include positions for 60 casks per pad. Each cask is approximately 12 feet $(3.7 \mathrm{~m})$ in diameter and 22 feet $(6.7 \mathrm{~m}) \mathrm{high}$, we ighs about 244 tons (220 MT), and stands upright on the support pad.

A concrece cask manufacturing plant and a concrete batch plant are included in the overali MRS facility for the sealed storage cask storage area design. Because making concrete casks does not involve nuclear materials, the cask manufacturing plant will be located outsice the security areas of the MRS facility.

At the cask manufacturing plant, steel reinforcing bar, metal 1 iners, and anbedment hardware are received as purchased parts and are set in concrete to fom the casks. The concrete cask closure pluys (shielding plugs) are fabricated separately but adjacent to the casks on the assembly 1 ine. Cask inanufacturing is done inside the plant, and areas are provided for warehousing, officts, locker rocms, lunch rooms, etc.

Commercially produced vehicles and mobile cranes are availabie that, with little or no modification, can be used for cask transport.

\subsubsection{Field Drywell Design Concept}

A field drywell storage area has stationary, in-ground, ory, sealed containers for storing canisters of spent fuel, HLW and RHTRU. The storage area consists of an array of these near-surface drywells into which canisters of radioactive material are placed for storage and frorn which the canisters can be retrieved for final disposition. The drywells can be different sizes to accormodate different sizes of canisters. Canisters of wastes for drywells are expected to range from 12 to 24 inches (0.3-0.6 m) in diameter and 10 to 17 feet $(3-5.2 \mathrm{~m})$ in height.

Drywells provide a passive method of safely storing spent fuel, hLW, and RHTRU. They use the surrounding soil as both a radiation shield and a conduction path to remove decay heat gerserated by spent fuel. (a) The canisters and the sealed drywell provioe double barrier containment.

In general terms, a crywell is a corrosion-resistant steel liner installed in a hole bored into the ground. The liner is usually set in the bored hole using a cement grout that fills empty spaces and therefore enhances the heat transfer from the liner to the adjoining soils. Surrounding the top of the liner is a concrete pad that provides a working surface for transport machinery. After a canister of waste and its shield plug are lowered into the dryweit, a cover is installed to isolate the drywell curtents from the environment.

The system for transferring the spent fuel, HLW, and RHTRU from the R\&H facility to the drywells consists of a transfer shield and a transport venicle. The canister hanaling system consists of a cylindrical shield, a movable shield doar assembly on the bottom of the shield, a grapple, hoist mechanisins, and a control system. The hoist mechaniss is a standard, comercially available jib crane. Controls for the hoist, jib crane, shield daor, and the shield plug lifting mechanism are in a panel in the transport vehicle. All of the controls and mechanisms are designed with interlocks to ensure fail-safe operation.

The drywe it is prepared to receive the canister by removing the temporary cover, examining the interior to assure that no water or extraneous debris is present, and cleaning the sealing ring on the 1 iner flange. The transport vehicle aligns the transfer shield with the drywell, the canister is grappled and raised slightly, the shield door is opened, and the canister and shield plug are lowerec until the canister is seated on the botton of the drywell. After the transfer shield is removed from the top of the drywell, the permanent drywell cover is welded in place. The weld is then cleaned and fnspected, and a protective paint is applied to complete the loading sequence.

\subsection{PROVISIONS FOR EXPANSION, EXTENDED STORAGE, AND DECOMMISSIONING}

The MRS facility is designed so that the R\&H facility and the storage area can be easily expanded. The R\&H facility can be expanded to handle twice the initial 1,800 MTU/yr throughput rate, and the storage a rea can be expanded to a maximum capacity of 70,000 MTU. More casks and more storage pads or more drywells can be constructed as needed to store incoming wastes.

(a) The geologic medium (earth, granite, limestone, etc.) of the specific storage site determines both the depth at which spent fuel must be placed ano the spacing between drywelis necessary to maintain acceptable temperatures. The feasibility of this method of dry storage has been demonstrateo with actual spent fuel at several locations, including the Nevada Test Site ano the Idaho National Engineering Laboratory. 
The wastes can be stored for extended periods of time in these passive, dry storage containers. As time passes, the radioactive materiais naturally decay so there is less and less radioactive material inside the canisters. The monitoring systems ensure detection of any releases of radioactivity from the the storage containers.

At any time, however, should it be appropriate to move the wastes, they can be easily retrieved from their storage locations and repackaged (if necessary) in the R\&H facility for shipping off site. After all wastes have been removed from the MRS facility, it can be safely decomissioned, and the land can be restored to unrestricted use.

\subsection{STORAGE DESIGN CONCEPTS NOT SELECTED FOR DETAILED ANALYSIS}

Of the eight passive, dry storage concepts considered, six were not selected for aivanced conceptual aesign. These were: 1) stationary metal cask, 2) concrete cask-in-trench, 3) tunnel drywell, 4 ) opencycle vault, 5) closed-cycle vault, and 6) tunnel rack vault. Water pool storage was also eliminated from consideration in this anaiysis because it is not a method of passive, dry storage. These concepts are described briefly in Appendix $A$. 


\subsection{REFERENCE-SITE DESCRIPTIONS}

This chapter describes in table form the reference sites used as the bases for estimating the impacts presentea in Chapters 4 and 5. Specific sites for an MRS were not yet nominated at the time this environmental document was being prepared. Therefore, reference sites (hypothetical locations) were developed by the forlowing process.

First, reference-site types were selected. The criterion was to select types that had a high probability of showing significant differences in environmental effects (including socioeconomic effects). Numerous types of sites were analyzed for potential differences. It was concluded that 3 types shculd represent the three major climatological conditions present in the contiguous United States; $i . e .$, arid, colo wet, and warm wet.

Next, representative site descriptions were prepared for each site type, based on available information. A literature search identified 182 sites in the contiguous United States for which extensive descriptions were available. ito new information was developed by onsite measurements or observations. The primary sources of information were environmental assessments, reports, and impact staterents issued for the representative sites plus numerous general references in the open literature for physical conditions throughout the United States (e.g., general geological, meteorologicat and socioeconomic data). Analysis of the locations of the 182 sites revealed that 21 sites ( 7 for each site type) would provide anple infomation representative of the 3 types of sites. The 21 representative site descriptions were selected from the 182 available by clustering the descriptions on a geographical basis and then selecting the description in each cluster that had most of the needed information, was representative of typical favorable siting conditions in that cluster, and was representative of numerous sites in the region containing that cluster.

Finally, reference site descriptions were developed for each site type. The 21 representative site descriptions were analyzed to detemine the ranges of the characteristics and the ease of finding sites with those characteristics. For each characteristic, a baseline aescription was selected (and then rounded) to provide a single representative value for the environinental analysis.

The reference site descriptions were developed by a multi-disciplinary team of Pacific Northwest Laboratory (PNL) personnel. The data reproduced in this chapter is contained in a memo dated November 5 , 1984, from J. R. Young (PNL) to D. J. Silviera (PNL), "MRS Reference Site Descriptions."

Included in these reference-site descriptions are data on the geophysical environment, the ecological environment, and the socioecononics associated with each reference site. For all 3 reference sites, the background radiation dose (whole body) is assumed to be 100 mrem/yr.

In the tables that follow, a value for a given variable (such as depth to ground water) that has been used for the reference site might not necessarily be typical for the entire site type. Fur this reason and to provide added information to evaluate the sites, many variables include a single value for the reference site and a range of values (in parentheses) typical of the entire site type. Thus, undue concern should not be given to a single value that might appear to preclude locatiun of an MRS facility in a particular place, because, although that value may be valid for the reference site, it may not be characteristic for all potential sites in that cilmatic type.

The sociueconomic data contained in these tables are forecasted values for the year 1992, the year in which construction of the MRS facility is assumed to begin. They are shown to provide a picture of the socioeconomic conditions that would prevail just before HRS construction. 
TABLE 3.1. Meteorology

\begin{tabular}{|c|c|c|c|c|c|c|c|c|c|c|c|c|c|}
\hline \multirow[b]{2}{*}{ Site } & \multirow{2}{*}{\multicolumn{3}{|c|}{ Temperature $\left({ }^{\circ} \mathrm{C}\right)$}} & \multirow{2}{*}{$\begin{array}{l}\text { Heating } \\
\text { Requirentents (a) } \\
\text { (degree days) }\end{array}$} & \multirow{2}{*}{\multicolumn{2}{|c|}{$\begin{array}{c}\text { Snow Loads } \\
\text { (psf) }\end{array}$}} & \multicolumn{7}{|c|}{ Precipitation (cm) } \\
\hline & & & & & & & & $\begin{array}{l}\text { Annoal } \\
\text { aximum }\end{array}$ & $\begin{array}{l}\text { Annual } \\
\text { Minimumi } \\
\end{array}$ & $\begin{array}{l}\text { Maximum } \\
24 \mathrm{hr} \\
\end{array}$ & $\begin{array}{l}\text { Maximuri } \\
1 \mathrm{hr} \\
\end{array}$ & $\begin{array}{l}\text { Mean } \\
24 \mathrm{hr}\end{array}$ & $\begin{array}{l}\text { Mean } \\
1 \mathrm{hr}\end{array}$ \\
\hline Arid & 139 & $\begin{array}{l}45 \\
\text { to } 48)^{(b)}\end{array}$ & $(-42$ to -9$)$ & $\begin{array}{c}4,000 \\
(1,900 \text { to } 10,000)\end{array}$ & 110 & $\begin{array}{l}20 \\
\text { to } 40)\end{array}$ & 128 & $\begin{array}{l}89 \\
\text { to } 89)\end{array}$ & $(3$ to 20$)$ & $\left(\begin{array}{l}13 \\
\text { to } 17\end{array}\right)$ & $\begin{array}{l}5 \\
\left.\begin{array}{lll}2 & \text { to } & 6\end{array}\right)\end{array}$ & $\begin{array}{c}4 \\
(2 \text { to } 5)\end{array}$ & 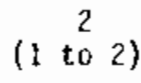 \\
\hline Warn Wet & $(40$ & $\begin{array}{l}45 \\
\text { to } 48)\end{array}$ & $\left(\begin{array}{l}-15 \\
-33 \text { to }-10)\end{array}\right.$ & $(1,100$ to 6,200$)$ & $(10$ & $\begin{array}{l}15 \\
\text { to } 30)\end{array}$ & $(94$ & $\begin{array}{l}178 \\
\text { to } 196)\end{array}$ & $\begin{array}{c}76 \\
(25 \text { to } 86)\end{array}$ & 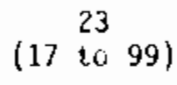 & $\left(\begin{array}{cc}8 \\
7\end{array}\right.$ to 11$)$ & 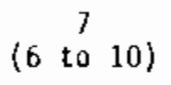 & $(3$ to 5$)$ \\
\hline Coid Het & $(39$ & $\begin{array}{l}45 \\
\text { to } 46)\end{array}$ & $\left(-43\right.$ to $\left.^{-35}-27\right)$ & $\begin{array}{c}7,500 \\
(7,100 \text { to } 10,500)\end{array}$ & $(20$ & $\begin{array}{l}25 \\
\text { to } 50)\end{array}$ & $(56$ & $\begin{array}{l}114 \\
\text { to } 183)\end{array}$ & $\left(23^{51}\right.$ to 71$)$ & $\begin{array}{l}15 \\
(10 \text { to } 31)\end{array}$ & $\begin{array}{c}8 \\
(5 \text { to } 9)\end{array}$ & $\begin{array}{c}6 \\
4 \text { to } 6)\end{array}$ & (2 to 3 ) \\
\hline
\end{tabular}

\section{Maximuin Probable ${ }^{(c)}$}

Arid

29 to 38$) \quad(34$ to 38$)$

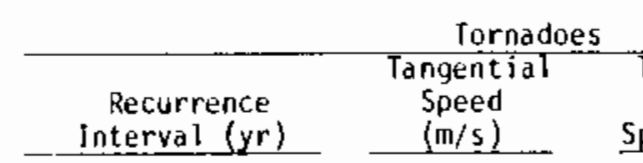

9,000

$(9,000$ to 560,000$)$

89

(5 to 104$)$

Transla-

tiond Pressure Drop Speed $(\mathrm{m} / \mathrm{s}) \quad$ (psi/sec)

$(17$ to 27

0.9

$(0.24$ to 1.1$)$

ite is $=8 \mathrm{~km}$ from Class I area,

ide boundaries of norlat tachment a rea for ${ }^{\circ} 0_{2}$, within nunattainment

Warin We

$26 \begin{aligned} & 27 \\ & \text { to } 38) \quad(31 \text { to } 41)\end{aligned}$

1,400

$(150$ to 8,200$)$

$(105$ to

$12 \quad 27$

36)

1.3

Site is $>8 \mathrm{kin}$ from Class I area,

outside boundaries of nonattijument areas for SO, arid TSP

Cold Wet

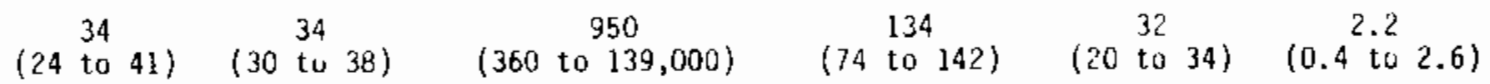

Site is $28 \mathrm{~km}$ from Class I area, outside boundaries of nonattainment areas for $\mathrm{SO}_{2}$ and TSP

\footnotetext{
(a) Degree days are calculated by subtracting the daily near teluperature from a reference temperature (usually 18 ${ }^{2}$ ).

(b) Numbers in parentheses iridicate ranges for typical sites of the type being described.

(c) Probable wifid speed is defined as the fastest wind speed at 10 ab above the ground with an annual probability of 0.02 (i.e., 50-year recurrerice interval).

(d) ISP - total suspended particulates.
} 


\section{TABLE 3.2. Hydrology}

Site

Arid

Waril Wet

Cold wet

Warn Wet

Depth to water-beuring zone $2150 \mathrm{~m}$ (12 to $500 \mathrm{~m}$ ); ground water available in shallow wells; total dissolved solids content $>3,000 \mathrm{ppm}$; water trom nearest source needs to be lifted over $90 \mathrm{~m}$; costs for treatment iluderate to high

No perennial streams or other surface waters located on site; nearest source of water $25 \mathrm{~km}$ (2 to $70 \mathrm{~km}$ ) away; located near natural divide; potential for flooding negligible, 90 m above historical flood level of nearest river

Abundant at site; major river (a) borders site; numerous smaller streanis; $>50$ constructed and 200 natural ponds; site 1 ies 3 km southwest of major reservoir; waters generally soft, slightly acidic, low in dissolved solids; flooding potential low since sandy soils permit rapid filtration of rainfall; site located $40 \mathrm{~m}$ above peak historical flood; estinated lift for usage $246 \mathrm{~m}$ from nornal river level to center of site; major river supplies inunicipal water upstream and downstrean of site

Located $8 \mathrm{~km}(<1$ to $10 \mathrm{~km})$ from a major river; flooding potential low with a midximum precipitation intensity of $8 \mathrm{~cm} / \mathrm{hr}$; site elevation 260 in above previous maximum flood of river; water usage fron underground sources

Water table 9 to 15 in (2 to 260 il) below ground surface; two deep adquifers, prolific water producers far inunicipal and industrial users; 20 counicipal water users withir $30 \mathrm{~km}$ of the site using $39,000 \mathrm{~m}^{3} /$ day; sufficierit water supplies for dornestic use occur ill the shalluwer aquifer

Cold Wet Water table within 9 m of surface in a glacial dritt aquitard; underground water use moderately inportant, within a 16-km radius for numicipal, industrial, and public use; water in alluvial aquifer has haraness of 325 to 561 ppm, total dissolved solids ranging from 404 to 751 ppin, and sulfate content of 263 ppin; water treatment costs should be suall

(a) Class B, suitable for donestic use with mininal treatment. 
TABLE 3.3. Geology and Physiography

\begin{tabular}{|c|c|c|}
\hline Site & Ground Slope & Contour Changes \\
\hline Arid & $\begin{array}{l}1 \%(.1 \% \text { to } 3 \%) \text {, elevation } \\
\text { difference of } 100 \text { in from } \\
\text { eastern to western border }\end{array}$ & $\begin{array}{l}\text { 3\% of the site has abrup } \\
\text { contour changes } 15 \mathrm{~m} \\
\text { from average elevation, } \\
\text { topographically monotonous } \\
\text { and } 5 \text { lightly hummocky }\end{array}$ \\
\hline Warm Wet & $\begin{array}{l}1 \%(1 \% \text { to } I q) \text {, elevation } \\
\text { difference for } 40-\mathrm{km}- \\
\text { wide drea } 30 \mathrm{~m}\end{array}$ & $\begin{array}{l}\text { Located on plateau with } \\
\text { interfluvial areas with } \\
\text { narrow valleys; } 3 \% \text { of th } \\
\text { site has abrupt contour } \\
\text { changes } 15 \text { in from averag } \\
\text { elevation }\end{array}$ \\
\hline \multirow[t]{2}{*}{ Cold wet } & $1_{*}^{\alpha}\left(1_{\infty}^{*}\right.$ to $\left.3_{\sim}^{\infty}\right)$ & $\begin{array}{l}\text { Land gently rolling with } \\
\text { elevation ranging from } \\
213 \mathrm{~m} \text { to } 221 \mathrm{~m} \text { above mean } \\
\text { sea level; } 3 \% \text { of the sit } \\
\text { has abrupt contour change } \\
15 \mathrm{~m} \text { from average } \\
\text { elevation; maximum } \\
\text { topographical relief } \\
68 \mathrm{~km} \text { over } 3 \text { to } 4 \mathrm{~km}\end{array}$ \\
\hline & $\begin{array}{c}\text { Ground Therma l } \\
\text { Conductivity }\left(\mathrm{W} / \mathrm{m}^{\circ} \mathrm{K}\right)^{(\mathrm{a})} \\
\end{array}$ & Soil Makeup \\
\hline Arid & $0.8(0.1$ to 3.0$)$ & $\begin{array}{l}3 \text { to } 5 \text { m of wind-blown } \\
\text { sand, } 1 \text { to } 2 \text { in of } \\
\text { cal iche, I m of fine- } \\
\text { grained friable } \\
\text { sandstone }\end{array}$ \\
\hline Warn Wet. & $1.2(0.2$ to 4.0$\}$ & $\begin{array}{l}300 \text { m of unconsolidated } \\
\text { and semiconsolidated } \\
\text { grave?, sand, silt, } \\
\text { clay with some marl } \\
\text { and limestone over- } \\
\text { laying basement } \\
\text { crystailine rocks }\end{array}$ \\
\hline Cold ivet & $1.2(0.1$ to 4.0$)$ & $\begin{array}{l}0 \text { to } 1.2 \text { m of loess, } \\
\text { allurium, and outwash } \\
\text { and } 36 \text { to } 43 \text { m of till } \\
\text { un } 1 \text { imestone, shale, } \\
\text { and sandstone }\end{array}$ \\
\hline
\end{tabular}

(a) $\sqrt{3 / m}{ }^{3} K$ - watts per meter per jegree Kelvin.

IABLE 3.4. Seismicity

$\begin{array}{ll}\frac{\text { Site }}{\text { Arid }} & \frac{\text { Seismic Risk Zone }}{\text { Warm Wet }} \\ \text { Soismic Risk Zone } 1^{(a)}(1 \text { to } 3) \\ \text { Cold Wet } & \text { Seismic Risk Zone } 2^{(b)}(0 \text { to } 2) \\ & \text { Seismic Risk Zone } 1(1 \text { to } 2)\end{array}$

(a) Historically, minor damage to the area from earthquakes. (b) Historically, moderate damage to the area. 
TABLE 3.5. Terrestrial Ecology

Site

Arid

Wam thet Trees characteristic of swaclupy lowiands;

cypress, tupelo, guni; varitty of oak,

hickory, ash, and pine in higher elevations; undergrowth vegetation duininated by huckleberry and variety of grasses

Cold Wet site occupies land presently used for row-crop production. esserilially void of naturd] vegetation; isulated areas cuntain stands of hardwood trees including oak, hickory, maple and ash; cottonwood and willow cccur along water courses

\section{- Insects \\ Darkling beetle and} grasshopper con-

spicuous didd abundant: huneybee can be a potential biologica] vector for transfer of radionuclides from environinent to humans

\section{Reptiles and Auphibians \\ A variety of lizards snakes and amphibians llay be present; ankunt of surface water midor determinant in number dild type of species}

Conspicuous components of the terrestrial ecosystein did play inportant parts in variuus food webs: especially in oldfield areas throughout region

Conspicious components uf terrestrial ecosystems and play important roles in various fuud webs
Wide variety due to abundance of aquatic hobitats; approximately 40 species. iqucluding several turtle, lizard, and snake specjes, and Adkerican alligator

Wuderate number of species, with aniphibians concentrated and wure numerous where water is present
Birds

$>100$ species; hornto lark and westeri meadowlark most abundant shrubsteppe nesting birds open waters importan resting and feeding areas for migrating waterfowl; resident upland game birds include mourning dove, chukar partridge, California quall, Chinese ring-necked pheasant, arid sage grouse

$>100$ spectes; uplatio game species include quall, dove and turkey; waterfow are prevalent

50 to 100 species of birds on site; upland galie birds include grouse, pheasant. partridge, quail. woodcock, dove; waterfowl numerous
Mallirials

Mamial population domi ndted by smaller species: variety of rodents,

rabbit, ground squirrel, pocket gopher:

intermediate-size coyote, raccoon, fox, badger, and with enough upen water beaver and unskrat; large: mule deer and antelope

Wide variety of species; snall: rabbit, shrew, mole, squirrel, numerous rodent; intemediate-size: rácoon, beaver, fox, bobcat, inuskrat, mink; large: white-tailed deer and black bear

Variety of small manuals typical of agricultural land: rodent, shrew, squirrel, rabbit;

interuediate-size:

raccoon, fox; larye: white-tailed deer 
TABLE 3.6. Aquatic Ecology

\begin{tabular}{|c|c|c|}
\hline Site & Bodies of Water & Food Webs \\
\hline Arid & $\begin{array}{l}\text { Nearby rivers; con- } \\
\text { structed impoundments }\end{array}$ & $\begin{array}{l}\text { Algae, macrophytes, invertebrates; } \\
\text { fish: crappie, bass, carp, sunfish }\end{array}$ \\
\hline Wam Wet & $\begin{array}{l}\text { Several streams, } \\
\text { extensive swamps; } \\
\text { large constructed } \\
\text { jmpoundment }\end{array}$ & $\begin{array}{l}\text { Diverse fish: large- and smali- } \\
\text { mouth bass, sunfish, catfish, } \\
\text { crappie, carp and associated } \\
\text { fuod web components }\end{array}$ \\
\hline Cold wet & $\begin{array}{l}\text { Large river; con- } \\
\text { structed impoundment }\end{array}$ & $\begin{array}{l}\text { Carp, bulthead, shiner and } \\
\text { associated food web components }\end{array}$ \\
\hline
\end{tabular}

TABLE 3.7. Threatened ana Endangered Species

\begin{tabular}{|c|c|c|c|c|}
\hline Site & Birds & Manmals & Reptiles & Plants \\
\hline Arid & $\begin{array}{l}\text { Peregrine falcon and } \\
\text { bald eagle occasional } \\
\text { migrants through site }\end{array}$ & ilone & None & $\begin{array}{l}\text { Occasiona } 1 \text { endangered } \\
\text { and rare plants may be } \\
\text { in isolated iucations }\end{array}$ \\
\hline Warm Wet & $\begin{array}{l}\text { Peregrine falcon and } \\
\text { bald eagle occasional } \\
\text { inigrants through site; } \\
\text { red-cockaded wood- } \\
\text { pecker and Kirtland's } \\
\text { warbler on site }\end{array}$ & None & Anerican alligator & None \\
\hline Cold Wet & None & None & None & None \\
\hline
\end{tabular}

TABLE 3.8. Land Use

\begin{tabular}{|c|c|c|c|c|}
\hline Site & Comgitinent of Land & Crops & Recreation & Archeological Sites \\
\hline Warm wet & $\begin{array}{l}\text { Woudland with limited } \\
\text { general faming, } \\
\text { nearby incustrial } \\
\text { areas }\end{array}$ & $\begin{array}{l}\text { Soy beans, cotton, } \\
\text { poultry, soft fruit }\end{array}$ & $\begin{array}{l}\text { Fishing, boating, } \\
\text { bird and large } \\
\text { animal hunting }\end{array}$ & Numerous on sice \\
\hline Cold Wet & $\begin{array}{l}\text { Falming, hog and } \\
\text { cattle raising, } \\
\text { mineral extraction, } \\
\text { (clay, sandstone) } \\
\text { wam-water fishing, } \\
\text { some manufacturing, } \\
\text { suburban develupmient }\end{array}$ & $\begin{array}{l}\text { Curn, oats, soy } \\
\text { beans }\end{array}$ & $\begin{array}{l}\text { Upland bird } \\
\text { hunting, fishing, } \\
\text { boating }\end{array}$ & None known \\
\hline
\end{tabular}


TABLE 3.9. Estimated Population, Year $1992^{(a)}$

\begin{tabular}{|c|c|c|c|c|c|}
\hline Site & $\begin{array}{l}\text { Persons/mi2 } \\
\text { Within } 5 \mathrm{mi} \\
\end{array}$ & $\begin{array}{l}\text { Persons in }(b) \\
\text { Central County } \\
\end{array}$ & $\begin{array}{l}\text { Persons in } \\
\text { Noncentra] } \\
\text { County } \\
\end{array}$ & $\begin{array}{l}\text { Population of } \\
\text { Major City } \\
\text { within } 50 \mathrm{mi} \\
\end{array}$ & $\begin{array}{l}\text { Total Populatjg9 } \\
\text { of Study Area }\end{array}$ \\
\hline Arid & 5 & 119,000 & 143,000 & 50,000 & 262,000 \\
\hline Warra Wet & 10 & 130,000 & 861,000 & 100,000 & 991,000 \\
\hline Coid Wet & 15 & 162,000 & $2,675,000$ & 100,000 & $2,837,000$ \\
\hline
\end{tabular}

(a) Source: MASTER/CCAM/FI model runs. See Appendix $D$ for explanation of models.

(b) Population of the county containing the MRS site.

(c) Population of counties surrounding the MRS site, excluding the central county, the majority of whose population is lucated within 50 miles $(80 \mathrm{~km})$ of the s'RS site.

(d) Sur of central county and noncentral county populatiuns.

TABLE 3.10. Estimated Employment for Surrounding Counties, Year $1992^{(a)}$

\begin{tabular}{|c|c|c|c|c|c|c|c|c|c|}
\hline \multirow[b]{2}{*}{ Site } & \multirow[b]{2}{*}{$\begin{array}{c}\text { Number } \\
\text { Employed }\end{array}$} & \multicolumn{8}{|c|}{ Enployment Oistribution $(y)$} \\
\hline & & Constructian & Mining & Farming & $\begin{array}{l}\text { Manufac- } \\
\text { turing } \\
\text { Qurables } \\
\end{array}$ & $\begin{array}{c}\text { Manutac- } \\
\text { turing } \\
\text { Non- } \\
\text { durables } \\
\end{array}$ & Retail & Services & Government \\
\hline Arid & 101,000 & 2.1 & 12.9 & 2.2 & 3.2 & 5.2 & 16.7 & 11.7 & 31.6 \\
\hline Harm wet & 183,000 & 3.7 & 0.2 & 2.4 & 4.1 & 11.5 & 13.2 & 19.3 & 33.5 \\
\hline Cold wet & 722,000 & 2.6 & 0.1 & 0.8 & 9.3 & 3.8 & 15.6 & 28.3 & 25.7 \\
\hline
\end{tabular}

(a) SourCe: MASTER/CCAM/FI modeT runs. See Appendix $D$ for explanation of models. 
TABLE 3.11. Forecasted Comanity Services, $1992^{(a)}$

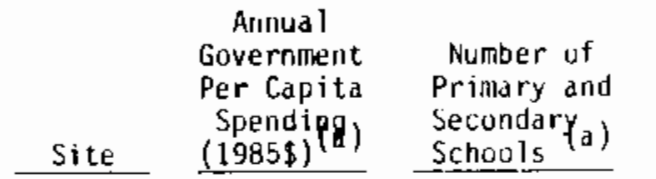

$\stackrel{\omega}{\infty}$

Arjd

6,861

65

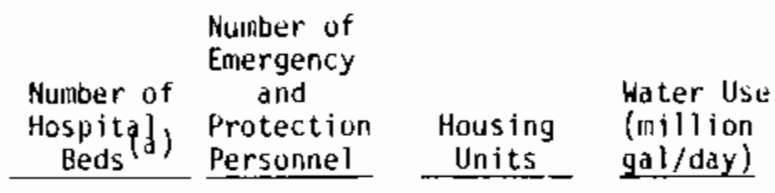

$96,000 \quad 780$

275

450

1,050

Warm Wet 6,539

4,513

12,650

$1,052,000$

4,490

Cold Wet

(1)

(a) Source: MASTER/CCAM/FI Mudel Runs (see Apperidix 0); Hammond Medallion World Atlas.

Transportation

Adequate transportation arteries; capacity of major streets, roads, and highways tends to exceed peak load; increased traffic

could be accomodated

without congestion

Adequate transportation to site

No major transportation arteries; one river within $5 \mathrm{mi}$ used for comercial navigation

\section{Recreation}

Public picnic areas, tennis courts, golf courses, swimming pools, bowling alleys

Park areas, flat water recreation available

Parks for picnick-

ing, camping,

boating 


\subsection{IMPACTS ASSOCIATED WITH SITE/CONCEPT COMBINATIONS}

In this section the potential environmental effects, or impacts, of building, operating, and decommissioning an MRS facility are discussed. The potential impacts are estimated for these categories: 1) radiological, 2) air quality, 3) water quality and use, 4) land use, 5) biological, 6) socioeconomic, and 7) resource requirements and costs.

The impacts of a sealed storage cask facility or a field drywell facility at each of the three reference sites, arid, warm wet, and cold wet (six site/concept combinations in ali), are presented. The analyses of potential effects are for an MRS facility with an operating lifetime of 25 years (refer to Chapter 2 for a list of the basic assumptions used to estimate these impacts). Hany impacts are the same or nearly the same for all site/concept combinations.

\subsection{RADIOLOGICAL IMPACTS}

The potential radiological impacts, including cumulative effects, are presented here for construction, operation, decomissioning, and transportation activities of the six site/concept combinations. Radiological consequences are based on one year of uperation at the design throughput rate (see Chapter 2 ).

\subsubsection{Construction Activities}

The construction phase of the MRS will not involve spent fuel or other radioactive waste forms to be stored at the MRS. While some of these materials may be on site during the latter stages of construction, they will not be involved in construction activities and their impacts are included under normal operations.

\subsubsection{Operation Activities}

This section presents the potential radiological impacts from normal operation of an MRS facility for all site/concept combinations. Details of analysis methods are in Appendix $B$.

Exposure of the public during nomal operations may result from airborme effluents reieased during cask venting and consolidation of spent fuel. No significant releases are expected from handi ing other waste types because only spent fuel contains the volatile radionuclides ${ }^{3} \mathrm{H}, \mathrm{Kr}$ and I. Spent-fuel venting and consolidation operations would be perfomed in hot cells in the R\&H facility, where all releases pass through the air filtration system.

As part of nomal operations, the spent-fuel cask atmosphere is vented to the ventilation system before removal of the cask head. It is assumed that $0.01 \%$ of the fuel rods will be received in a damaged state and portions of their radionuclide inventories will be released to the interior of the cask during nomal operations (OOE 1978).

If the fuel rods are to be consolidated, the fuel rod bundles will be disassembled in the hot cells. Disassembly involves laser cutting the ends off the fuel rod bundles, a process that does not involve the fuel directly but might cause airborne release of built-up reactor corrosion products (crud). Radioactive release for this operation is calculated by estimating crud composition and by incorporating data on laser cutting operations. The airborne material from crud and structural steel components is passed through an in-cell filter (90\% efficiency) and three nigh-efficiency particulate air (HEPA) filters (each tested to 99.97\% efficiency). A conservative estimate of the transmissions of particulate material through the filters is $10^{\circ}$. No credit is calculated for plateout on the heating, ventilating, and air conditioning duct surfaces. The $85 \mathrm{Kr}, 129 \mathrm{I}$ and ${ }^{3} \mathrm{H}$ releases are not reduced by filtration.

Fuel rods tend to swell in the harsh environment of a reactor core, and $0 . I^{x}$ to $0.3^{*}$ of the rods become stuck in the spacers of the fuel rod bundles (Funk and Jacobson 1979). Some of these fuel rods may then rupture during removal. In this analysis, a conservative assumption is made that $0.3 \%$ of the rods become stuck and that 50* of these are ruptured during removal. This rate corresponds to 1 rod rupture per every 3 PWR assemblies or 1 per every 11 BWR assemblies. As specified in Regulatory Guide 1.25 (NRC 1972), $30 \%$ of the ${ }^{85} \mathrm{Kr}$ and $10 \%$ of the ${ }^{3} \mathrm{H}$ and ${ }^{129} \mathrm{I}$ inventories are assumed to be released from each ruptured rod.

For a processing rate of $1,800 \mathrm{MTU} / \mathrm{yr}$, the curies released per year as the result of nomal cask venting and rod consolidation are given in Table 4.1. These activities are releases to the atmosphere after passing through the filter system.

The radiological consequences from normal release from cask venting and rod consolidation are shown in Table 4.2. The dose commitment to the maximally exposed individual is small compared to the annual limits of $75 \mathrm{mrem}$ to thyroid or 25 mrem to other organs (10 CFR 72). The exposure to the maximum individual and to the population is very small compared with the annual dose from background radiation. 
TABLE 4.1. Annua1 Atmospheric Release of Radionuclides from Cask Venting and Rod Consolidation of Spent Fuel

$\underline{\text { Radionuclides }}$

${ }^{3} \mathrm{H}$

$60 \mathrm{Co}$

$85 \mathrm{Kr}$

$129 \mathrm{I}$
Annual Releases (Ci/yr)

$$
\begin{aligned}
& 9.3 \times 10^{1} \\
& 6.7 \times 10^{-9} \\
& 4.3 \times 10^{3} \\
& 9.5 \times 10^{-3}
\end{aligned}
$$

\begin{tabular}{|c|c|c|c|c|c|c|}
\hline \multirow{3}{*}{$\begin{array}{l}\text { Pathway } \\
\text { and Location } \\
\text { in the Body } \\
\end{array}$} & \multicolumn{6}{|c|}{ 50-Year Cose Commitment from Annual Release } \\
\hline & \multicolumn{2}{|c|}{ Maximum Individual } & \multirow{2}{*}{$\begin{array}{l}(\text { rent } \\
\text { Cold wet }\end{array}$} & \multicolumn{3}{|c|}{ Population (person-rem) } \\
\hline & Arid & Warm Wet & & Arid & Warm wet & Cold Wet \\
\hline \multicolumn{7}{|l|}{ Background (Annual) } \\
\hline Total body & $1.0 \times 10^{-1}$ & $1.0 \times 10^{-1}$ & $1.0 \times 10^{-1}$ & $2 \times 10^{4}$ & $6 \times 10^{4}$ & $1.6 \times 10^{5}$ \\
\hline \multicolumn{7}{|l|}{ Air Submersion } \\
\hline ATI locations & $4.5 \times 10^{-6}$ & $1.0 \times 10^{-6}$ & $1.4 \times 10^{-6}$ & $2 \times 10^{-2}$ & $1 \times 10^{-2}$ & $4 \times 10^{-2}$ \\
\hline \multicolumn{7}{|l|}{ Inhalation } \\
\hline Total body & $3.5 \times 10^{-6}$ & $7.6 \times 10^{-7}$ & $1.0 \times 10^{-6}$ & $1 \times 10^{-2}$ & $1 \times 10^{-2}$ & $3 \times 10^{-2}$ \\
\hline Bone & $9.4 \times 10^{-9}$ & $2.1 \times 10^{-9}$ & $2.9 \times 10^{-0}$ & $4 \times 10^{-5}$ & $3 \times 10^{-5}$ & $8 \times 10^{-5}$ \\
\hline Lungs & $3.7 \times 10^{-5}$ & $8.0 \times 10^{-7}$ & $1.1 \times 10^{-6}$ & $1 \times 10^{-2}$ & $1 \times 10^{-2}$ & $3 \times 10^{-2}$ \\
\hline Thyroid & $2.5 \times 10^{-5}$ & $5.4 \times 10^{-6}$ & $7.5 \times 10^{-6}$ & $1 \times 10^{-1}$ & $7 \times 10^{-2}$ & $2 \times 10^{-1}$ \\
\hline \multicolumn{7}{|l|}{ ingestiun } \\
\hline Total body & $4.3 \times 10^{-5}$ & $1.3 \times 10^{-5}$ & $1.3 \times 10^{-5}$ & $7 \times 10^{-2}$ & $9 \times 10^{-2}$ & $1 \times 10^{-i}$ \\
\hline Bone & $2.0 \times 10^{-5}$ & $4.5 \times 10^{-5}$ & $6.2 \times 10^{-6}$ & $5 \times 10^{-2}$ & $4 \times 10^{-2}$ & $1 \times 10^{-1}$ \\
\hline Lungs & $3.5 \times 10^{-5}$ & $1.1 \times 10^{-5}$ & $1.1 \times 10^{-5}$ & $6 \times 10^{-2}$ & $7 \times 10^{-2}$ & $1 \times 10^{-1}$ \\
\hline Thyroid & $6.2 \times 10^{-3}$ & $1.9 \times 10^{-3}$ & $2.0 \times 10^{-3}$ & $7 \times 10^{0}$ & $1 \times 10^{i}$ & $1 \times 10^{1}$ \\
\hline \multicolumn{7}{|l|}{ Tutal for All } \\
\hline \multicolumn{7}{|l|}{ Exposure Pathways } \\
\hline Total body & $\begin{array}{l}5.2 \times 10^{-5} \\
2.5 \times 10^{-5}\end{array}$ & $\begin{array}{l}1.5 \times 10^{-5} \\
5.5 \times 10^{-6}\end{array}$ & $1.5 \times 10^{-5}$ & $\begin{array}{l}1 \times 10^{-1} \\
7 \times 10^{-2}\end{array}$ & $\begin{array}{l}1 \times 10^{-1} \\
5 \times 10^{-2}\end{array}$ & $2 \times 10^{-1}$ \\
\hline Lungs & $4.3 \times 10^{-5}$ & $1.0 \times 10^{-5}$ & $1.3 \times 10^{-5}$ & $9 \times 10^{-2}$ & $\begin{array}{l}5 \times 10^{-1} \\
1 \times 10^{-1}\end{array}$ & $2 \times 10^{-1}$ \\
\hline Thyroid & $6.2 \times 10^{-3}$ & 1. $9 \times 10^{-3}$ & $2.0 \times 10^{-3}$ & $7 \times 10^{0}$ & $1 \times 10^{1}$ & $1 \times 10^{1}$ \\
\hline
\end{tabular}

TABLE 4.2. Radiological Impacts from Normal Cask Venting and Rod Consolidation of Spent Fuel

\subsubsection{Operating Accidents}

A prelimirary accident evaluation for the HRS facility has been completed. (The evaluation is in a draft regulatory assessment document being prepared by the Ralph M. Parsons Company, Pasadena, Caljforilia.) This prelininary analysis and the conceptual design have been used as the basis for this accident evaluation. Four "design event" classifications are used to describe the range of severity possible for accidents at an MRS that may result in release of radionuclides beyond the controlled area. The characteristic of each "design event" class is given in Table 4.3 .

Events of Class I include cask venting and release of volatiles during fuel assembly consolidation. Releases from these events have been included in the routine release source temis and will not be considered further. The majority of the offsite radiation doses received during normial operations are due to the releases resulting from class I design events.

Events of Class II, III, and IV represent accidents and are considered in the present analysis. The purpose of the present analysis is to provide a bound of potential accident inpacts for the MRS facility. The basis for the analysis is the preliminary accident evaluation performed by the architect-engineer and the conceptual design. This information is expected to be sufficient in deternining the worst lixely consequences because the accidents considered are based on maximum unit quantities of radionuclides (i.e., fuel assenbly, transpurt cask, storage cask) involved in the operations.

Events of Class II are initiated by mechanical failures, operator errur, or electrical power failure and have lictle potential for release of radionuclides beyond the confined area in which the accident accurs. The CTass II event considered in the present analysis involves dropping of a fuel assembly in the 
TABLE 4.3. Design Event Classes

Design Event Class

I

II

III

IV
Class Description/Initiating Event

Planned operational events that occur frequently with minor releases (not considered accidents)

Events with a reasonable likelihood of occurrence during a typical year of MRS operation

Infrequent events that could occur during the MRS design lifetime or that could potentially result in a dose of 25 mrem or greater at the boundary of the controlled area

Events initiated by natural phenomena that are unlikely to occur during the MRS design lifetime but require consideration

R\&H facility hot cell caused by failure of the lifting and handling systems or operator error. For the design throughput rate of 1,800 MTU/yr, about one fuel assembly drop per year would be expected baseo on observed events (Bailey 1983). However, only one fuel assembly drop event (out of 34 total) has ever been observed to release radioactive material from the fuel rods (and that was a minor release).

The events of Class III have a greater potential for offsite consequences than the Class II events but are less likely to occur. Two Class III events are considered in the present analysis: i) a diesel fuel fire involving a transport cask in the receiving yard and 2) a transport cask arop in the receiving and inspection area.

Events of Class IV are initiated by severe natural phenomena and are highly unlikely to occur. The facility is designed to withstand earthquakes and tornadoes without loss of containment capabilities. Therefore, releases of radionuclides from these events are unlikely. For the present analysis, an earthquake or tornado is assumed to be a contributory cause to accidents in the storage area during emplacement or retrieval operations. The postulated accident in the storage area is dependent on the storage concept. For the sealed storage cask concept, the accjent involves dropping or overturning a storage cask. For the field drywell concept, the accident involves shearing a canister during emplacement in a drywell. The Class III accidents are representative of design basis accidents. Because a detailed safety analysis of the MRS facility has not been done, the accidents presented represent a preliminary estimate of design basis accidents.

The release of radionuclides for each accident is based on handing of spent fuel with the highest activity considered in the basis for the MRS. Based on the inventories shown in Table 4.4, this is fuel exposed to 55,000 MWD/MTJ at 10 years out of reactor. The impact analyses are performed for this fuel type. All of the accidents considered involve handling of spent fuel. While other waste types will be handled at the MRS facility, spent fuel is expected to give bounding consequences because the most likely radionuclides to be released are those of the more volatile elements (i.e., $H, I$, and $K r$ ). Spent fuel has the largest inventory of these volatile radionuclides.

The radionuclide inventories given in Table 4.4 represent the activity in spent fuel based on 1 MTL initialiy loaded into a reactor. To detemine activities released from fuel during an accident, it is only necessary to estimate the equivalent weight of fuel involved in the accident and apply appropriate release factors. For example, if a PWR fuei assembly (containing 0.462 MTHM) has $2 \%$ of its fuel rods damaged, then $0.02 \times 0.462$, or 0.00924 , is the equivalent amounc of fuel from which activity may be released. For fuel at 55,000 MWD/MTU and 10 years old, this could involve $0.00924 \times 490$ or $4.5 \mathrm{Ci}$ of ${ }^{3} \mathrm{H}$. This method is used in the following accident scenario descriptions in determining activities released to the atmosphere.

TABLE 4.4. Inventory of Selected Radionuclides in Spent Fue?

Radionuclide

${ }^{3} \mathrm{H}$

${ }^{129}$ I

${ }^{35} \mathrm{Kr}$

$\frac{3,000 \mathrm{MhO} / \mathrm{M}}{(5 \mathrm{yr})}$
$4.1 \times 10^{2}$
$3.2 \times 10^{-2}$
$6.7 \times 10^{3}$

Activity (Ci/MTHM)

\begin{tabular}{|c|c|}
\hline $\begin{array}{c}33,000 \mathrm{~N} / \mathrm{W} / \mathrm{MTU} \\
(10 \mathrm{yr})\end{array}$ & $\begin{array}{c}55,000 \mathrm{MWO} / \mathrm{M} \\
(10 \mathrm{Yr})\end{array}$ \\
\hline $3.1 \times 10^{2}$ & $4.9 \times 10^{2}$ \\
\hline $3.2 \times 10^{-2}$ & $5.0 \times 10^{-2}$ \\
\hline $4.9 \times 10^{3}$ & $7.4 \times 10^{3}$ \\
\hline
\end{tabular}


Offsite impacts are presented in Tabie 4.5 for sealed storage cask accidents and in Table 4.6 for field drywell accidents. Details of each accident scenario and the postulated source terms are provided in the discussions below. The impacts presented in these tables are based on the assumption that the accident uccurs; the probability of the event is not factored into the impact calculation.

TABLE 4.5. Summary of Radiological Impacts from Potential Accidents, Sealed Storage Cask

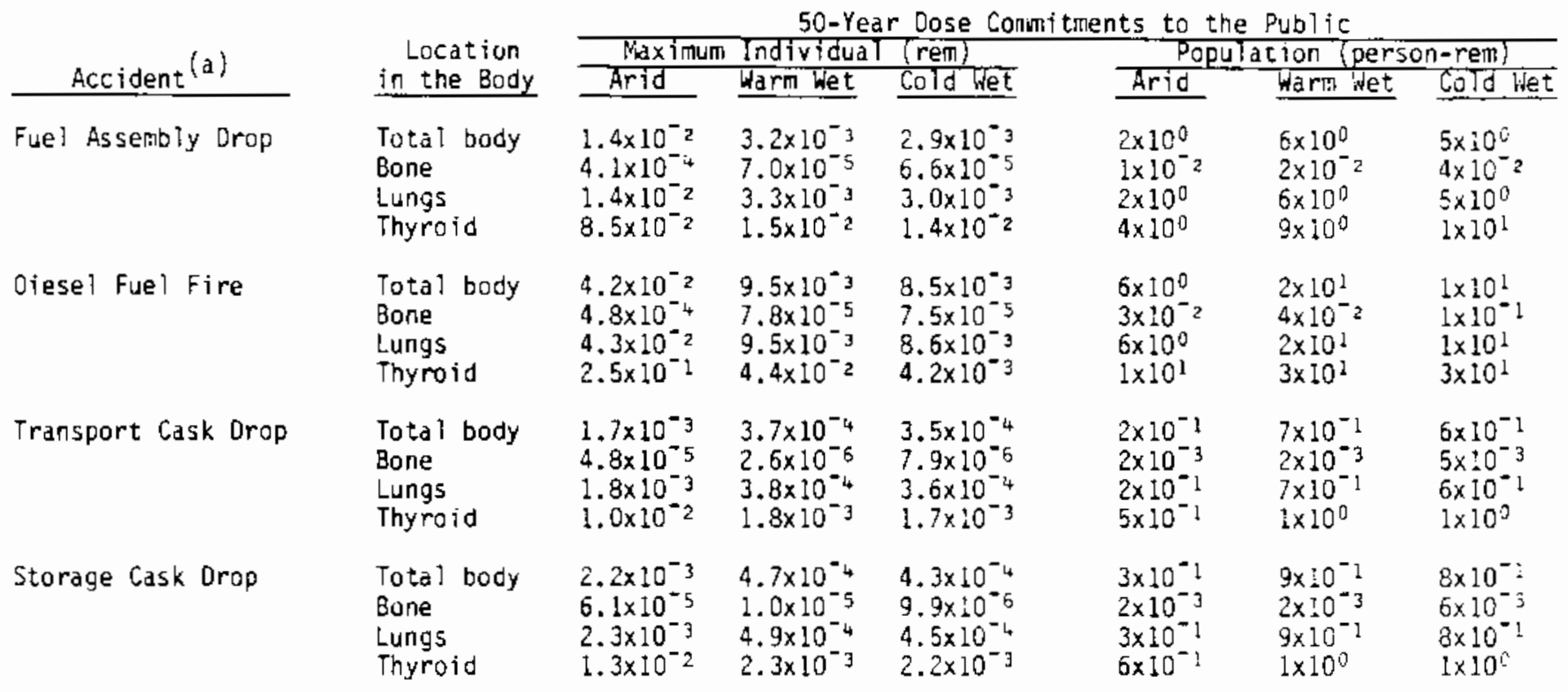

(a) Ath accidents are analyzed for handing of spent fuel because that would have the highest release.

TABLE 4.6. Sumary of Radiological Impacts from Potential Accidents, Field Drywell

\begin{tabular}{|c|c|c|c|c|c|c|c|}
\hline \multirow{3}{*}{ Accident $(a)$} & \multirow{3}{*}{$\begin{array}{l}\text { Location } \\
\text { in the Body }\end{array}$} & \multicolumn{6}{|c|}{ 50-Year Dose Comitments to the Public } \\
\hline & & Maximum & Individual & (rem) & Pop & timiper & $n-$ rem) \\
\hline & & Arid & Warm Wet & Cold niet & Arid & Warm wet & Cola net \\
\hline Fuel Assembiy Drop & $\begin{array}{l}\text { Total body } \\
\text { Bone } \\
\text { Lungs } \\
\text { Thyroid }\end{array}$ & $\begin{array}{l}6.3 \times 10^{-3} \\
2.4 \times 10^{-4} \\
6.5 \times 10^{-3} \\
3.1 \times 10^{-2}\end{array}$ & $\begin{array}{l}1.9 \times 10^{-3} \\
4.4 \times 10^{-5} \\
1.9 \times 10^{-3} \\
6.6 \times 10^{-3}\end{array}$ & $\begin{array}{l}1.7 \times 10^{-3} \\
4.3 \times 10^{-5} \\
1.8 \times 10^{-3} \\
6.6 \times 10^{-3}\end{array}$ & $\begin{array}{l}2 \times 10^{0} \\
1 \times 10^{-2} \\
2 \times 10^{\circ} \\
4 \times 10^{\circ}\end{array}$ & $\begin{array}{l}6 \times 10^{0} \\
2 \times 10^{-2} \\
6 \times 10^{0} \\
9 \times 10^{0}\end{array}$ & $\begin{array}{l}5 \times 10^{1} \\
4 \times 10^{-2} \\
5 \times 10^{0} \\
1 \times 10^{1}\end{array}$ \\
\hline Diesel Fuel Fire & $\begin{array}{l}\text { Total body } \\
\text { Bone } \\
\text { Lungs } \\
\text { Thyroid }\end{array}$ & $\begin{array}{l}1.8 \times 10^{-2} \\
2.6 \times 10^{-4} \\
1.8 \times 10^{-2} 2 \\
9.0 \times 10^{-2}\end{array}$ & $\begin{array}{l}5.4 \times 10^{-3} \\
4.9 \times 10^{-5} \\
5.5 \times 10^{-3} \\
1.9 \times 10^{-2}\end{array}$ & $\begin{array}{l}5.0 \times 10^{-3} \\
5.0 \times 10^{-5} \\
5.1 \times 10^{-3} \\
1.9 \times 10^{-2}\end{array}$ & $\begin{array}{l}6 \times 10^{0} \\
3 \times 10^{-2} \\
6 \times 10^{0} \\
1 \times 10^{1}\end{array}$ & $\begin{array}{l}2 \times 10^{1} \\
4 \times 10^{-2} \\
2 \times 10^{1} \\
3 \times 10^{1}\end{array}$ & $\begin{array}{l}1 \times 10^{1} \\
1 \times 10^{-1} \\
1 \times 10^{1} \\
3 \times 10^{1}\end{array}$ \\
\hline Transport Cask Drop & $\begin{array}{l}\text { Total body } \\
\text { Bone } \\
\text { Lungs } \\
\text { Thyroid }\end{array}$ & $\begin{array}{l}7.5 \times 10^{-4} \\
2.9 \times 10^{-5} \\
7.8 \times 10^{-4} \\
3.7 \times 10^{-3}\end{array}$ & $\begin{array}{l}2.2 \times 10^{-4} \\
5.3 \times 10^{-6} \\
2.3 \times 10^{-4} \\
7.8 \times 10^{-4}\end{array}$ & $\begin{array}{l}2.1 \times 10^{-4} \\
9.7 \times 10^{-6} \\
2.1 \times 10^{-4} \\
7.9 \times 10^{-4}\end{array}$ & $\begin{array}{l}2 \times 10^{-}: \\
2 \times 10^{-3} \\
2 \times 10^{-1} \\
5 \times 10^{-1}\end{array}$ & $\begin{array}{l}7 \times 10^{-1} \\
2 \times 10^{-3} \\
7 \times 10^{-1} \\
1 \times 10^{0}\end{array}$ & $\begin{array}{l}6 \times 10^{-1} \\
5 \times 10^{-3} \\
6 \times 10^{-}: \\
1 \times 10^{0}\end{array}$ \\
\hline Canister Shearing & $\begin{array}{l}\text { Total body } \\
\text { Bone } \\
\text { Lungs } \\
\text { Thyroid }\end{array}$ & $\begin{array}{l}1.9 \times 10^{-2} 2 \\
7.0 \times 10^{-4} \\
2.0 \times 10^{-2} 2 \\
2.5 \times 10^{-2}\end{array}$ & $\begin{array}{l}5.7 \times 10^{-3} \\
1.3 \times 10^{-4} \\
5.8 \times 10^{-3} \\
2.0 \times 10^{-2}\end{array}$ & $\begin{array}{l}5.4 \times 10^{-3} \\
1.3 \times 10^{-4} \\
5.5 \times 10^{-3} \\
2.0 \times 10^{-2}\end{array}$ & $\begin{array}{l}6 \times 10^{0} \\
4 \times 10^{-2} \\
6 \times 10^{0} \\
1 \times 10^{1}\end{array}$ & $\begin{array}{l}2 \times 10^{1} \\
5 \times 10^{-2} \\
2 \times 10^{1} \\
3 \times 10^{1}\end{array}$ & $\begin{array}{l}2 \times 10^{1} \\
1 \times 10^{-}= \\
2 \times 10^{1} \\
3 \times 10^{1}\end{array}$ \\
\hline
\end{tabular}

(a) AlT accidents are analyzed for handirig of spent fuel because that would have the highest release.

Fuel Assembly 0rop. Removal of fuel assemblies from the transportation cask involves lifting the assemblies vertically from the cask into the R\&H facility hot cell. Ouring this operacion, it is assumed that failure of the lifting and handing system, failure of the lifting bail, or operator error results in 
aropping one PWR fuel assembly (PWR assemblies contain more activity that BWR assemblies). Operating procedures and equipment are designed to minimize the potential for this type of accident. observations of actual fuel assembly drop events (34 events) show that only one event resulted in the reiease of radioactive gases (and that was a minor release) (Bailey 1983). The assembly is assumed to fall at an angle against the cask rim or other structure resulting in breakage of all fuel elements. This will result in release of volatile fission products to the hot-cell interior and to the atmosphere via the HEPA filtration. system and the facility stack. As specified in Regulatory Guide 1.25 (NRC 1972), 30\% of the $85 \mathrm{Kr}$, and 102 of the ${ }^{3 \mathrm{H}}$ and $129 \mathrm{I}$ are assumed to be released. This is equivalent to release of $1,000 \mathrm{Ci} 85 \mathrm{Kr}, 23 \mathrm{Ci}{ }^{3} \mathrm{H}$, and $0.0023 \mathrm{Ci} 129 \mathrm{I}$.

Diesel Fuel fire. A diesel fuel fire could occur in the transport/receiving area of the MRS. The iikelihood of this happening is low because of the operational procedures and minimal ignition sources. The worst fire scenario would involve a leak in the diesel fuel tank of a truck or yard locomotive. It is assumed that the fuel leaks onto the ground under a transport cask and is ignited. The probability of the fuel tank leaking and not being detected is quite low.

The U.S. Code of Federal Regulations (49 CFR 173) states that the transport cask must survive in a $1,475^{\circ} \mathrm{F}$ totally engulfing fire for a period of 30 minutes. This test is onty one in a series of four consecutive tests; the others are drop, puncture and immersion tests. The maximum allowable release after these tests is $1,000 \mathrm{Ci}$ of $85 \mathrm{Kr}$ and $10 \mathrm{Ci}$ each of ${ }^{3} \mathrm{H}$ and $129 \mathrm{I}$. It is anticipated that the fire will be extinguished in less than 30 minutes and that the actual severity of the fire will not reach that of the test conditions; thus, no release is expected. However, for the present analysis, it is assumed that krypton is released equivalent to the test limit of $1,000 \mathrm{Ci}$. This is $2.4 \%$ of the highest krypton activity in one rail cask (12 assemblies with $0.462 \mathrm{MT} /$ assembly, 55,000 MWD/MTU at 10 years). A corresponding fraction of the ${ }^{3 \mathrm{H}}$ and $129 \mathrm{I}$ is also assumed to be released. This results in a total release of 1,000 Ci of $85 \mathrm{Kr}, 66 \mathrm{Cj}$ of $3 \mathrm{H}$, and $0.0058 \mathrm{Ci}$ of $129 \mathrm{I}$.

Transport Cask Drop. This accident involves dropping a transportation cask during transfer from the transport vehicle (truck or railcar) at the R\&H facility. Currently, licensed shipping casks must oe lifted from the carrier and placed on a cask cart to allow for mating with the hot-celf inlet. During the lifting operation, the transport cask could be dropped: this is unikely because of the design of the litting equipment. All overhead cranes will have retainers to prevent derailinent, and lifting yokes will be structurally overdesigned.

The U.S. Code of Federal Regulations (49 CFR 173) specifies that the cask must survive a $30-f o o t$ drop onto a flat, unyieliing surface followed by a puncture test, exposure to a temperature of $1,475^{\circ} \mathrm{F}$ for 30 minutes, and a water imersion test; after these tests, the cask is allowed to leak a maximum of $1,000 \mathrm{Ci}$ of $85 \mathrm{Kr}$ and $10 \mathrm{Ci}$ each of $3 \mathrm{H}$ and $129 \%$. The carrier unioading facility will be designed so that a cask will not be lifted more than 30 feet in the air. The cask drop scenario is much less severe than the tests and the cask is assumed to remain intact. However, for the present analysis it is assumed that li: cf the fuel rods are damaged in the drop (100 times the failure rate for nomal shipping operations). It is assumed that $30 \%$ of the krypton and $10 \%$ of the tritium and iodine in the broken fuel rods are released to the cask interior as specified in Regulatory Guide 1.25 (NRC 1972). Upon venting of the cask, the volatile radionuclides are released through the ventilation system to the atmosphere. Any particulate material would be captured in the HEPA filtration system. Assuming the accident involves a raiT cask with 12 PWR fuel assemblies (maximum content), the total release to the atmosphere (through the facility stack) would be $130 \mathrm{Ci}$ of $85 \mathrm{Kr}, 2.7 \mathrm{Ci}$ of ${ }^{3} \mathrm{H}$, and $2.7 \times 10^{-4} \mathrm{Cj}$ of $129 \mathrm{I}$.

Storage Cask Drop (Sealed Storage Cask Concept). This accident could occur during emplacement of a sealed storage cask. A tracked vehicle is used to transport a cask to the storage site, and a mobile crane ifts the cask from the transporter and places it on a storage pad. During the transport/emplacement operation, the cask could be dropped or tipped over. Through engineered safety features, structural overdesign, and prudent operating procedures, the probability of this accident is minimized. A seismic event is assumed to be a prime cause of this accident.

The lifting height from the transporter to the storage pad is minimized by prudent operating procedures. If a cask were dropped, the outer concrete shield could crack, but the inner metal liner should remain intact. Thus, no immediate release of radionuclides to the atmosphere is expected. For the present analysis, it is assumed that $5 \%$ of the fuel rods in une of the 12 canisters in the cask are ruptured and radioactivity is released to the interior of the canister. It is assumed that the cask is returned to the R\&H facility for repackaging of the fuel as a precautionary measure. When the canister is opened, the volatile fission products from the $5 \%$ failed fuel rods will be released to the hot cell and to the atmosphere via the HEPA filtration system. As specified in Regulatory Guide 1.25 (NRC 1972), it is assumed that $30 \%$ of the krypton and $10 \%$ each of the tritium and iodine are released from the damaged fuel rods to the atmosphere. For a PWR canister ( 3 fuel assemblies with 1.4 MT heavy metal), the release would be $160 \mathrm{Ci} 85 \mathrm{Kr}, 3.4 \mathrm{Ci} 3 \mathrm{H}$, and $3.6 \times 10^{-4} \mathrm{Ci} 129 \mathrm{I}$.

Canister Shearing (Field Drywell Concept). When a field drywell canister is being placed into or retrieved from its drywell, it would be subject to shearing if the transport vehicle inoved. Safety features of the transport vehicle inhibit vehicle movement during emplacement or retrieval so that the 
probability of a canister shearing accident is minimized. However, for the present analysis, a seismic event is assumed to be the prime cause of vehicle movement. The amount of canister damage from the shearing action depends on the force behind the vehicle movement. Action strong enough to completely shear the canister into two pieces is very unlikely. For the present analysis, it is assumeo that the shearing accident results in tearing of the canister shell and that all of the fuel rods are damaged enough to release a fraction of their volatile fission products to the atmosphere. As before, it is assumed that $30 \%$ of the krypton and $10 \%$ of the tritium and iodine are released from the dariaged fuel rods. The fuel rods are not assumed to be damaged sufficiently to cause airborne release of a significant amount of particulate material. The total release of volatile fission products is $3,100 \mathrm{Ci} 85 \mathrm{kr} 69 \mathrm{Ci}, 3 \mathrm{H}$, and $7 \times 103 \mathrm{Ci} 129 \mathrm{I}$.

\subsubsection{Decommissioning Activities}

The MRS facility is designed to facilitate decontamination/decommissioning of structures and equipinent and tu minimize exposure of the public and workers. Decomissioning of the storage areas begins during retrieval operations. Final decomissioning of all facilities will be perfomed after all spent fuel aric waste packages have been removed from the site and after removal, decontamination, and disposa! of major equipment. The decomissioning will be completed upon renoval of all radioactive material dcwn to residual levels that are acceptable for release of the property for unrestricted use (10 CFR 20.105). The R\&H facility will be placed in a safe shutdown mode, and the storage area for the sealed storage cask concept remains with decontaminated casks in place. The field drywell area will be covered with topsoil.

During the storage period, the cask and drywell monitoring system will detect leakage from failed canisters. When failure is detected, the cask or drywell canister will be returned to the RoH facility for transfer of waste to new storage units. The sealed storage casks will be decontaminated for re-use or destroyed (if decontamination efforts are not effective). An attempt will be made to decontaminate drywells in place. Drywells that cannot be decontaminated will be sealed (welded shut) and left for the decomissioning phase. During decomissioning, these few contaminated drywells will be excavated intact and taken to the R\&H facility where they will be decontaminated or destroyed within the confined atmosphere of the hot cells (with HEPA filtration).

The CHTRU storage area wili be decomissioned using a temporary enclosure (air structure) during unloading ano packaging of the waste containers. The RßH facility will be used to decontaminate sealed storage casks, drywelis (that resist decontamination in place), and all contaninated components of the R\&H facility itseif. These decomissioning activities will be perfomed in hot cells (with HEPA filtration).

Decomissioning involves a relatively small amount of residual radioactivity. Because of the precautionary measures taken in handling this small amount of radioactive material during oeconmissioning, no significant offsite releases are anticipated for normal decomissioning operations of the MRS facility.

\subsubsection{Transportation Activities}

Radiological impacts from transport of spent fuel and wastes to an MRS facility were evaluated for a processing rate of $1,800 \mathrm{HTU} / \mathrm{yr}$. Impacts were also calculated for transport from the MRS to a geulogic repository. Two scenarios were considered: transport to a near repository (200 km) and transport to a distant repository $(4,000 \mathrm{~km})$. The analysis was performed for two cases: ali-truck transport and ali-rail transport. Actual shipment would be a combination of the two, but the impacts would be bounded by these values. Data and methods used in the analysis are presented in Appendix $B$.

The impacts were based on distance traveled, number of shipments of each waste type, and fraction of each trip through rural, suburban, and urban population zones. The impacts are only dependent on the site location; the storage design concept has no effect on impacts.

Results of the radiological impact analysis are presented in Table 4.7 for truck and rail transport. Calculated doses for transport from reactors to each MRS reference site and from each MRS site to two repository distances are given. The two geologic repository distances were chosen to provide boundaries for the potential impacts for transport from the MRS to the geologic repository. All values in Tabie 4.7 are for one year of operation (either emplacement or retrieval). The calculation of doses for transport to a geologic repository is conservative in that no credit for dose rate reduction from radiological decay (during storage in the MRS) is included.

The doses result from direct exposure to penetrating radiation and are, therefore, received during the year of exposure. The methodology developed by the Transportation Technology Center (used in this analysis only considers population exposures expressed in units of person-rem. The population group expused is the general public living in the area of shipment routes or passing shipments during transport. The workforce represents those involved in loading and transporting wastes. The impacts presented in Table 4.7 are small compared to annual exposures received by the same population groups from background radiation.

The radiological impacts from transportation accidents are calculated on a probabilistic basis (Wilmot et al. 1983). For a spectrum of potential accidents, the dose to the pubi ic is calculated and then weighted by the probability of the accident occurring. The total impact per unit distance traveled is then 
TABLE 4.7. Annual Radiological Doses to the Public from Normal Transport

\begin{tabular}{|c|c|c|c|}
\hline \multirow[b]{2}{*}{$\begin{array}{l}\text { Type of } \\
\text { Transport and site }\end{array}$} & \multicolumn{3}{|c|}{$\begin{array}{l}\text { Whole-Body Population Dose } \\
\text { (person-rem) for Transport Segment }\end{array}$} \\
\hline & To MRS & $\begin{array}{l}\text { MRS to Neats) } \\
\text { Repository }\end{array}$ & $\begin{array}{l}\text { MRS to Distapt } \\
\text { Repository }\end{array}$ \\
\hline $\begin{array}{l}\text { Background - Truck } \\
\text { Arid Site } \\
\text { Warm-Wet Site } \\
\text { Cold-Wet Site }\end{array}$ & $\begin{array}{l}7 \times 10^{4} \\
5 \times 10^{4} \\
5 \times 10^{4}\end{array}$ & $\begin{array}{l}6 \times 10^{3} \\
7 \times 10^{3} \\
7 \times 10^{3}\end{array}$ & $\begin{array}{l}1 \times 10^{5} \\
1 \times 10^{5} \\
1 \times 10^{5}\end{array}$ \\
\hline $\begin{array}{l}\text { A17-Truck Transport } \\
\text { Arid Site } \\
\text { Warm-Wet Site } \\
\text { Cold-Wet Site }\end{array}$ & $\begin{array}{l}8 \times 10^{2} \\
4 \times 10^{2} \\
4 \times 10^{2}\end{array}$ & $\begin{array}{l}6 \times 10^{1} \\
7 \times 10^{1} \\
7 \times 10^{1}\end{array}$ & $\begin{array}{l}1 \times 10^{3} \\
1 \times 10^{3} \\
1 \times 10^{3}\end{array}$ \\
\hline $\begin{array}{l}\text { Background - Rail } \\
\text { Arid Site } \\
\text { Warm-Wet Site } \\
\text { Cold-Wet Site }\end{array}$ & $\begin{array}{l}8 \times 10^{4} \\
6 \times 10^{4} \\
6 \times 10^{4}\end{array}$ & $\begin{array}{l}6 \times 10^{3} \\
7 \times 10^{3} \\
7 \times 10^{3}\end{array}$ & $\begin{array}{l}1 \times 10^{5} \\
1 \times 10^{5} \\
1 \times 10^{5}\end{array}$ \\
\hline $\begin{array}{l}\text { All-Rajl Transport } \\
\text { Arid Site } \\
\text { Warm-Wet Site } \\
\text { Cold-Wet Site }\end{array}$ & $\begin{array}{l}2 \times 10^{3} \\
1 \times 10^{3} \\
1 \times 10^{3}\end{array}$ & $\begin{array}{l}1 \times 10^{2} \\
1 \times 10^{2} \\
1 \times 10^{2}\end{array}$ & $\begin{array}{l}3 \times 10^{3} \\
3 \times 10^{3} \\
3 \times 10^{3}\end{array}$ \\
\hline
\end{tabular}

(a) Distance from MRS to a near repository is $200 \mathrm{~km}$.

(b) Distance from MRS to a distant repository is $4,000 \mathrm{~km}$.

calculated by suming over all accidents; these unit dose factors (calculated by wilmot et al. 1983) are presented in Appendix $B$. The dose calculations include the contribution from inhalation of radionuclides airborne during the accident and therefore should be considered dose commitments. Results of the analysis are presented in Table 4.8 for rail and truck transport for each waste type. The impacts presented are smail compared with annul background radiation received by people along the transportation route.

TABLE 4.8. Potential Doses from Transport Accidents

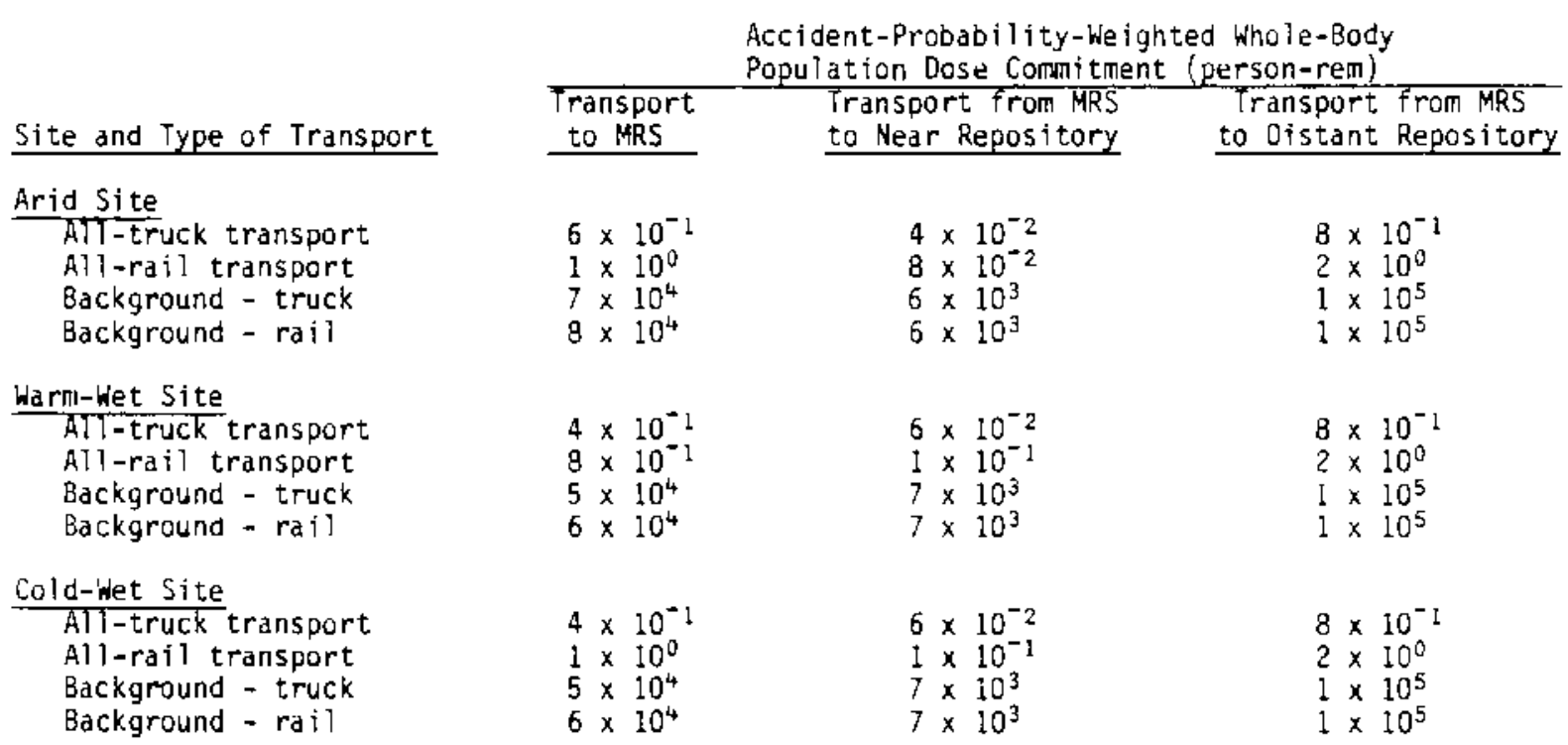

\subsubsection{Cunulative Effects}

The previous sections describing radiological impacts have only considered effects from the MRS. Should the MRS be located near other fuel cycle facilities, the regional population may be affected from two or more sources of radiation. The potential for cumulative effects is considered in this section by comparing MRS impacts with previously estimated impacts from various environmental assessments fur ather 
fuel cycle facilities. The fuel cycle facilities considered include a uranium mitl, a fuel enrichnent facility, a fuel fabrication facility, a power reactor and a fuel reprocessing facility.

The comparison of radiological impacts is made for the average individual exposure within 50 miles $(80 \mathrm{~km})$ of each facility. This was necessary to put the comparison on a common basis because population dose does not consider the effect of differing total populations in the vicinity of each facility. A surimary of the average individual doses is presented in Table 4.9. The average individual doses indicate no radiological hazard should the MRS be located with one or more facilities.

TABLE 4.9. Summary of Average Individual Exposure for Fuel Cycle Facilities, Routine Operation

Fuel Cycle Facility
Uranium Mill(a)
Gaseous Enrichment Plant (b)
Fuel Fabrication Plant
(c)
Nuclear Power Reactor $(d)$
PWR
BWR

Fuel Reprocessing Plant $(\mathrm{e})$ MRS (f)

Arid

Warm Wet

Cold Wet
Average whole-Body
Individual Dose (mrem)

$$
6.1 \times 10^{-2}
$$$$
8.0 \times 10^{-3}
$$$$
1.5 \times 10^{-3}
$$

$3.1 \times 10^{-3}$

$1.2 \times 10^{-2}$

$4.2 \times 10^{0}$

$4.3 \times 10^{-4}$

$$
1.6 \times 10^{-4}
$$$$
1.3 \times 10^{-4}
$$

\section{Cose Commitment

Period (yr)

50

50

50

50

70

50

50

50

(a) From NRC (1980)

(b) From EPA (1980b).

(c) From Fleming and Ross (1983).

(d) From Peloquin, Schwab and Baker (1982).

(e) From DOE (1980).

(f) Calculated as population dose (Table 4.2) divided by the population of the reference site.

\subsubsection{Sulmary}

The estimated radiological impacts to the public from routine activities for the six site/concept conbinations are compared in Jable 4.10. The impacts are represented by the 50-year whole-body dose compitments from one year of activity (i.e., construction, operation, decomissioning, or transportation). The radiological impacts are all very small compared with the annual dose from background radiation and, therefore, are not valid criteria for selection of one site/concept combination over others. The impacts presented in Table 4.10 are near or below the EPA annual dose 1 imit of 25 mrem for individuals and the Dog limit of 500 mrem.

Potential accidents have been considered for operation of the MRS. The radiological impacts of yossible accidents (Tables 4.5 and 4.6) are small compared with the annul dose from backgrouno radiation. Also, the impacts for individuals are within the 5 -rem limit for design basis accidents given in 10 CFR 72 (paragraph 68) and within the OOE philosophy of keeping public exposures to one-tenth of this value (500 mreni).

Exposures to the workforce were not considered because all work will be performed within safe work procedures and in accordance with ALARA principles. DOE limits for occupational exposures (5-rem whole body) will be met.

(a) Other organ doses are comparabie for the six site/concept combinations. 
TABLE 4.10. Summary of Radiological Impacts to the Public from Routine Activities (50-Year whole-Body Dose Commttment from One Year of Activity)

\begin{tabular}{|c|c|c|c|c|c|c|}
\hline \multirow[b]{2}{*}{ Population Group/Activity } & \multicolumn{3}{|c|}{ Sealed Storage Cask } & \multicolumn{3}{|c|}{ Field Drywell } \\
\hline & Arid Site & $\begin{array}{c}\text { Warm-Wet } \\
\text { Site }\end{array}$ & $\begin{array}{l}\text { Cold-wet } \\
\text { site } \\
\end{array}$ & Arid Site & $\begin{array}{l}\text { Wa rmi-ifet } \\
\text { Site } \\
\end{array}$ & $\begin{array}{l}\text { Cold-wet } \\
\text { Site }\end{array}$ \\
\hline $\begin{array}{c}\text { Background (person-rem) } \\
\text { Operation } \\
\text { Transportation }(a)\end{array}$ & $\begin{array}{l}2 \times 10^{4} \\
2 \times 10^{5}\end{array}$ & $\begin{array}{l}6 \times 10^{4} \\
2 \times 10^{5}\end{array}$ & $\begin{array}{r}1.6 \times 10^{5} \\
2 \times 10^{5}\end{array}$ & $\begin{array}{l}2 \times 10^{4} \\
2 \times 10^{5}\end{array}$ & $\begin{array}{l}6 \times 10^{4} \\
2 \times 10^{5}\end{array}$ & $\begin{array}{r}1.6 \times 10^{5} \\
2 \times 10^{5}\end{array}$ \\
\hline $\begin{array}{l}\text { Population (person-rem) } \\
\text { Operation } \\
\text { Transportation (a) }\end{array}$ & $\begin{array}{l}1 \times 10^{-1} \\
5 \times 10^{3}\end{array}$ & $\begin{array}{l}1 \times 10^{-1} \\
4 \times 10^{3}\end{array}$ & $\begin{array}{ll}2 \times 10^{-1} \\
4 \times 10^{3}\end{array}$ & $\begin{array}{l}1 \times 10^{-1} \\
5 \times 10^{3}\end{array}$ & $\begin{array}{l}1 \times 10^{-1} \\
4 \times 10^{3}\end{array}$ & $\begin{array}{l}2 \times 10^{-1}: \\
4 \times 10^{3}\end{array}$ \\
\hline $\begin{array}{l}\text { Individual (rem) } \\
\text { Operation } \\
\text { Transportation (a) }\end{array}$ & $\begin{array}{l}5.2 \times 10^{-5} \\
3.0 \times 10^{-2}\end{array}$ & $\begin{array}{l}1.5 \times 10^{-5} \\
2.8 \times 10^{-2}\end{array}$ & $\begin{array}{l}1.5 \times 10^{-5} \\
2.7 \times 10^{-2}\end{array}$ & $\begin{array}{l}5.2 \times 10^{-5} \\
3.0 \times 10^{-2}\end{array}$ & $\begin{array}{l}1.5 \times 10^{-5} \\
2.8 \times 10^{-2}\end{array}$ & $\begin{array}{l}1.5 \times 10^{-5} \\
2.7 \times 10^{-2}\end{array}$ \\
\hline
\end{tabular}

(a) Transportation doses include transport to and from the MRS for the highest dose mode (either rajl or truck) and for the farthest geologic repository (at $4,000 \mathrm{~km}$ ).

\subsection{AIR QUALITY IMPACTS}

Potential environmental impacts from emissions of nonradiological substances related to construction, operation, decomissioning, and transportation are discussed in this section. Routint emissions and accidents are presented, and estimated concentrations are compared with applicable afr quality standards.

\subsubsection{Construction Activities}

Dust from land disturbance and heavy vehicle traffic is the most significant air pollutant related co construction of the R\&H facility and storage area. The concentration of dust in the air depends on site factors such as rainfall and soil type, facility parameters such as disturbed area, and construction practices such as wetting or using surface stabilizers (Appendix B). There is considerabie uncertainty in predicting fugitive dust emissions. Dust emissions may vary greatiy from day to day depending on the level of activity, the specific operations, and the prevaling weather. A large portion of the emissiuns result from equipment traffic uver temporary roads at the construction site.

The arid site would have the greatest concentration of airborne dust. The projected concentrations of dust at the location of a resident 3 to $5 \mathrm{~km}$ downwind are below that set in the anbient air quality standards (40 CFR 50) at all three reference sites.

Increases in the concentration of particulate matter are addressed in "Prevention of Significant Deterioration of Air Quality" (40 CFR 51.24). Areas are designated as Class I, II, or III, each with a maximum allowable increase of particulate matter (annual average 5 to $37 \mathrm{~kg} / \mathrm{m}^{3}$ ) and sulfur dioxide (annual average 2 to $40 \mu \mathrm{g} / \mathrm{m}^{3}$ ). Estimated annual average concentrations of particulate matter at 3 to $5 \mathrm{~km} f r o m$ construction at the arid site are in the range of allowable increments for a class II area. The increments projected for the warmi-wet and cold-wet sites are in a range allowable for the Class 1 area. Sulfur oxide emissions are within the range set for Class I. Emissions from construction or other temporary emissionrelated activities are usually excluded from these requirements (40 CFR 51.24 f, "Exclusions from Increment Consumption").

The concrete batch plant and aggregate materials stored at the site are another source of fugitive dust. It is estimated that emissions from concrete batching and aggregate storage contribute less than loo. of the fugitive dust from construction operations.

Oiesel exhaust from heavy equipment contributes little to pollution levels. Vehicle fuel consumption during construction is estimated to be about 400,000 gallons (documented in letcer number P-PNL-235 from W. D. Woods, the Ralph M. Parsons Company, Pasadena, California, to D. S. Jackson (PNL) dated February 18, 1985). Estimated concentrations of nitrogen oxides and sulfur axides are less than iq of the concentraticn set in 40 CFR 50 .

Herbicides may be used to maintain areas free of vegetation during construction and operation af the facility. This is not expected to be a significant source of aiborne pollutants.

The impact of building an MRS facility is similar to that of any large construction project. The use uf heavy construction equipment on a large scale is temporary. Construction of storage pads for the 15,000 MTU capacity will be completed before the facility starts operating. The impact of expanoing the capacity of the facility from 15,000 MTU to 70,000 MTU by adding storage area and increasing the throughput 
of the R\&H facility is expected to be less than that of original site construction. Concentrations of pollutant emissions from construction at the location of a resident ( 3 to $5 \mathrm{~km}$ downwind) are within ambient standards.

Possible construction accidents that could adversely affect air quality include explosion of a fuel tank or drift of herbicides to adjacent land. Effects from aecident events would be limited in duration and localized primarily to the construction site. Negligible environmental impacts would be anticipated.

\subsubsection{Operation Activities}

The R\&H facility is the only major stationary source of gaseous emissions during routine operations. The greatest source of nonradioactive emissions is the combustion of fossil fuels. Arnual consumption of No. 2 fuel oil by boilers, emergency generators, and fire water pumps is estimated to be 950,000 gallons for the facility operating at capacity of $1,800 \mathrm{MTL} / \mathrm{yr}$. The maximum winter consumption rate is estimated to be 239,000 gallons per month. Natural gas would be used as an alternate fuel, if available, at a rate of 1.3 million scf/yr (standard cubic feet per year). Concentration of oxides of nitrogen and sulfur resulting from burning fuel oil at the maximum rate are less than $1 \%$ of the annual average set in the ambient air quality standards (40 CFR 50). Emisstons from the R\&H facility are basically the same, whether the storage facility is of cask or dryweli type.

Annual fuel consumption by vehicles is estimated to be 95,000 gallons of diesel fuel, and 60,000 gallons of unleaded gasoline (documented in letter number P-PNL-138 from W. 0 . Woods, the Raiph M. Parsons Company, Pasadena, California, to D. S, Jackson (PNL) dated October 5, 1984). Enissions of pollutants based on this fuel consumption rate would result in concentrations far below the level set by 40 CFR 50 .

Cement dust from a concrete batch plant for cask manufacturing would be a minor source of particulate matter. Sources of dust include outside storage and loading of aggregate and unloading, conveying and mixing aggregate and cement. Emission races may vary by a factor of 10 , depending on the adequacy of contro? measures. Controls include the use of enclosed dumping and loading areas and conveyers, filters on storage bins, and use of water sprays. With minimal dust control, offsite concentrations of dust from aggregate storage and concrete batching are estimated to be about $5 \%$ of the ambient standard at the worst case (ario) site. The drywell facility also requires a sindl amount of concrete batching (for the concrete collars around each drywe il).

A cooling tower (a) is required to disperse the heat generated by decay of spent fuel and by heatgenerating operations of waste processing in the R\&H factility. Evaporation and drift of water from the cooling tower are estimated to be 56,000 gpd average $(72,000$ gpd sumer design). Trace amount of cooling water additives may be emitted with water vapor from the cooling tower.

A nixture of helium and argon, both inert gases, is to be used in the hot cellis for welding operations. The anticipated use rate is $15,380 \mathrm{5cf} /$ month of argon and 1708 scf/month of heliull ( $90 \%$ argun, $10 \%$ helium). Inert gases, being nontoxic asphixiants, are of concern for industrial safety rather than environmental reasons.

Gleaning and decontamination of the sealed storage canisters in the hot cells wilt be done using
Freon (trichlorotrifiuoroethane), also known as Refrigerant 113 (R-113). Freon, a nonflammable
fluorinated hydrocarbon, will be recycled in the process. A $10 \%$ loss per cycle, or 1710 scf/menth is assumed. No adverse environmental effects are expected.

Ar witra-high-expansion fire-fighting foam will be used generally for cleaning contaminated walls and floors in the Rati factility. The foam is inert and produces liquia waste typically at about 0.07 gal/ft 2 .

No hazardous air pollutants defined in 40 CFR 61 are to be used at the facility.

Possible accidents could include equipment failure, site worker error, or fire. Adverse impacts from such accidents are mostly $\mathrm{l}$ imited to the site. Accidents such as release of argon gas in the $\mathrm{R} \& H$ facility are matters of industrial safety rather than of environmental concern.

\subsubsection{Decomissioning Activities}

Decomissioning is scheduled to begin when the stored material is transferred tu a repository. Decommissioning of the MRS facility will involve the immediate removal of all radioactive material down to residual levels that are acceptable for reiease of the property for unrestricted use. Equipment and facility components whose contamination levels are unacceptable after decontamination are to be dismantled and removed. Decontaminated components are to be stored pemanently at the site.

(a) This cooling tower is a factory-assembled, galvanized metal structure, 48 feet long, 21 feet wide, and $12 \frac{1}{2}$ feet high, with a flow rate of 5,000 gallons per minute.

- Freon is a registered trademark of the Du Pont de Nenours and Company, Inc. 
The decontaminating and dismanting operations are all done within the R\&H facility with adequate air filtering systems. There are no significant emissions of particulate matter during decomissioning.

Storage casks that cannot be decontaminated are destroyed and shipped to a low-level waste burial ground. Acceptable casks are stored pemanently on the existing storage pads. Dryweils that cannot be decontaminated to acceptable levels are sealed, removed, and shipped to a low-ievel waste burial ground. Drywells that are acceptable for unrestricted use are covered with soil for permanent storage.

Nonradiological impacts of decomissioning would be minimal. This mode of decomissioning entails little demolition work that would generate particulate emissions. Process emissions are limited by filtering, mainly to trap radioactive particies. There would be a small amount of fugitive dust from covering the drywells with soil; at a rate of 1,800 MTU/yr, 20 to 27 acres per year woutd be covered and stabilized.

Possible accidents may include loss of filtration. The quantities of particulate matter are very small and only of concern for radiological impacts. Decomissioning accidents would primarily affect workers within buildings; such accidents are not of environinental concern.

\subsubsection{Transportation Activities}

Routine emissions from transportation, including diesel exhaust and fugitive dust, are proportional to distances traveled. Nonaccident impacts from transportation are increased concentrations of combustion products.

Tonnages shipped are dependent on waste type and facility size. The overall enissions and use of fuel is proportional to distance traveled, while tocal concentrations depend on frequency of shipments and atmospheric dispersion. The concentration of airborne pollutants from truck and railcar traffic, based on continuous passage of one vehicle per hour, results in pollutant cuncentrations at least three orders of magnitude less than Ambient Air Quality Standards, 40 CFR 50 (Appendix B).

Transportation accidents could result in both occupational and nonoccupational injuries and fatalities. Injuries and fatalities projected for the transportation of waste to and from the MRS facility are given in Table 4.11. These projections are based on unit risk factors given in Appendix $B$ and shipping distances to the MRS and from the MRS to a near or distant repository. Trarisportation accidents involving release of volatile fuel or process chemicals could have oniy temporary effects on air quality.

\section{2 .5 Summary}

Potential air quality impacts from construction, operation, and decomissioning of sealed storage cask or field orywell facilities at each of three reference sites are compared in Table 4.12. Estimated concentrations froni routine emissions are compared with Federal Anibient Air Quality Standards, 40 CFR 50.

Construction of an MRS facility will have a short-lived impact on air quality near the chosen site. Operation and decomissioning of an MRS facility will have a minimal impact on the air quality of the local area.

Transportation of materials will have minimal impact on air quality along main transportation routes as well as at the facility site. Concentrations are expected to be well below ambient standards.

\subsection{WATER QUALITY AND USE IMPACTS}

Water quality impacts are evaluated in this section. For each activity, routine effluents, water consumption, and accidents that could affect water quality are considered.

The availability of water and water use permits are important in siting an MRS facility. Commitment of the water resource at each potential site must be considered, particularly in arid regions.

\subsubsection{Construction Activities}

Construction activities might possibly cause increased runoff from the disturbed site. This possibility could be reduced by selecting a nearly level site, providing proper drainage, and using standard construction practices to reduce runoff. The arid site has permeable, sandy soil and no perennial streams or surface waters. The warm-wet site has many sources of surface water, including a major river and nume rous smaller streams. Flooding potential is low because the sandy soil permits rapid infiltration of rainfall. The coid-wet site also has very little ground stope and permeable soil.

Water use during construction is primarily for concrete production, sanitary use, and dust control. About 10 milition gallons of water will be required to construct the facility, plus up to 30 million galions for dust control at the arid site. 
TABLE 4.11. Transportation Impacts: Nonoccupational Injuries and Fatalities(a)

\begin{tabular}{|c|c|c|c|}
\hline Site and Type of Transport & To MRS & $\begin{array}{l}\text { MRS to Neat) } \\
\text { Repos itory }\end{array}$ & $\begin{array}{l}\text { MRS to Dis } \\
\text { Repositor }\end{array}$ \\
\hline \multicolumn{4}{|l|}{ Arid Site } \\
\hline \multicolumn{4}{|l|}{ Truck Transport } \\
\hline $\begin{array}{l}\text { Injuries } \\
\text { Fatalities }\end{array}$ & $\begin{array}{l}6 \\
0.4\end{array}$ & $\begin{array}{l}0.6 \\
0.04\end{array}$ & $\begin{array}{l}11 \\
0.7\end{array}$ \\
\hline \multicolumn{4}{|l|}{ Rai] Transport } \\
\hline $\begin{array}{l}\text { Injuries } \\
\text { Fatalities }\end{array}$ & $\begin{array}{l}0.06 \\
0.03\end{array}$ & $\begin{array}{l}0.004 \\
0.002\end{array}$ & $\begin{array}{l}0.08 \\
0.04\end{array}$ \\
\hline \multicolumn{4}{|l|}{ Warm-Wet Site } \\
\hline \multicolumn{4}{|l|}{ Truck Transport } \\
\hline $\begin{array}{l}\text { Injuries } \\
\text { Fatalities }\end{array}$ & $\begin{array}{l}4 \\
0.2\end{array}$ & $\begin{array}{l}0.6 \\
0.03\end{array}$ & $\begin{array}{l}11 \\
0.7\end{array}$ \\
\hline \multicolumn{4}{|l|}{ Rail Transport } \\
\hline $\begin{array}{l}\text { Injuries } \\
\text { Fatalities }\end{array}$ & $\begin{array}{l}0.03 \\
0.02\end{array}$ & $\begin{array}{l}0.004 \\
0.002\end{array}$ & $\begin{array}{l}0.08 \\
0.04\end{array}$ \\
\hline \multicolumn{4}{|l|}{ Cold-Wet Site } \\
\hline \multicolumn{4}{|l|}{ Truck Transport } \\
\hline $\begin{array}{l}\text { Injuries } \\
\text { Fatalities }\end{array}$ & $\begin{array}{l}3 \\
0.2\end{array}$ & $\begin{array}{l}0.6 \\
0.03\end{array}$ & $\begin{array}{l}11 \\
0.7\end{array}$ \\
\hline \multicolumn{4}{|l|}{ Rail Transport } \\
\hline $\begin{array}{l}\text { Injuries } \\
\text { Fatalities }\end{array}$ & $\begin{array}{l}0.03 \\
0.01\end{array}$ & $\begin{array}{l}0.004 \\
0.002\end{array}$ & $\begin{array}{l}0.08 \\
0.04\end{array}$ \\
\hline
\end{tabular}

(a) Based on round-trip mileage.

(b) Distance from MRS to a near repository is $200 \mathrm{~km}$.

(c) Distance from MRS to a distant repository is $4,000 \mathrm{~km}$.

Unplanned events that could adversely affect water quality include spillage of fuei or herbicides. The possibility will be reduced by protecting the fuel tanks with a bermed area.

\subsubsection{Operation Activities}

Resource requirements. Water avaitability is an important factor that will be considered in actual site selection. The maximum water requirement for the MRS facility is about 210,000 gpd (gallons per day) at sumer cooling rates. The amount of water required to operate an MRS facility for one year (at the (a) sumer use rate) is roughly equivalent to that required to irrigate 80 acres of farmland for a seasun. (a) The maximum water consumption rate is about $170 \mathrm{gpm}$ (gallons per minute), which is a reasonable pumping rate from one well or from a snall well field. For comparison, a large center pivot irrigation systent may require 1,500 gprn.) The effect of withdrawing water at this rate on ground-water resources is highly dependent on the site geohydrology. In most locations pumping water at 170 gpm would have minimal effect on ground-water resources a mile or so from the site."

Variabies affecting water usage include climate at the site and the amount of spent fuel handled at the facility. Cooling tower makeup (127,000 gpd) and boiler feedwater makeup (43,800 gpd) account for most of the plant water requirement. Most of the cooling water is used to remove heat from the R\&H facility (HVAC uses a chilled water system). other uses of water include hot water boiler makeup, mix and washdown, sanitary use, and irrigation. Cask foming operations at a storage cask type of MRs facility require 6,000 gpd.

Each reference site has suitable ground-water supplies. The arid site has potable water about 90 or more meters deep. The warm-wet site has an ample supply of water, with 20 municipal users within 30 km of the site. The water table is 9 to 15 m below ground surface. At the cold-wet site, most water usage is from underground sources; the water table is generally within $9 \mathrm{~m}$ of the surface.

(a) Based on 36 inches of irrigation per season.

(b) Personal communication November 29, 1984, with A. E. Reisenauer (PNL). 
TABLE 4.12. Estimated Concentrations of Pollutants from Routine Construction, Operation, and Decommissioning Compared with National Primary Anbient Air Quality Standards (40 CFR 50)

\begin{tabular}{|c|c|c|c|}
\hline & Pol & Centratio & \\
\hline & Particulate & $\mathrm{NO}_{x}$ & $\mathrm{SO}_{x}$ \\
\hline Standard (40 CFR 50) & $\frac{(\text { annual) }(a, b, c)}{50-65 \mathrm{PM}_{10}}$ & $\frac{(\text { annua })}{100}$ & $\frac{(\text { annual) }}{80}$ \\
\hline
\end{tabular}

\section{Concept/Site and Activity}

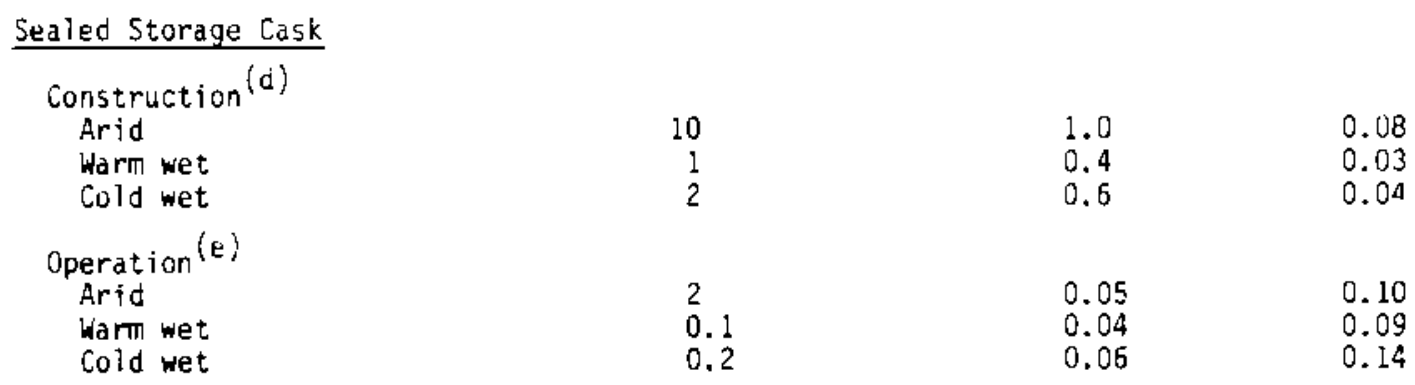

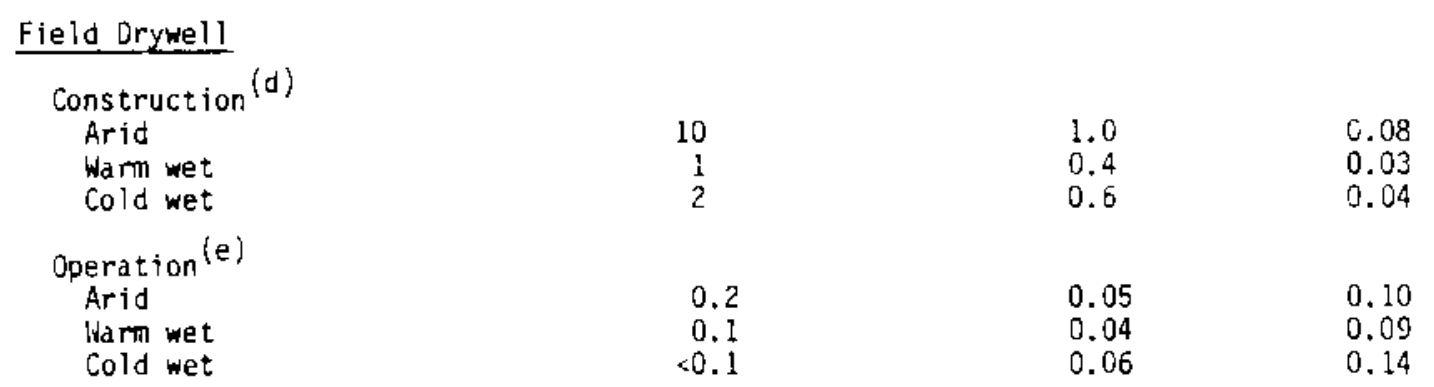

(a) Major contributor is fugitive dust; during construction, dust from earth removal; during operations and decomissioning, dust from movement of heavy equipment and trucks.

(b) A proposed revision would change the anibient standara for particulate matter from $75 \mu \mathrm{g} / \mathrm{m}^{3} \mathrm{TSP}$ (total suspended particulate) to $50-60 \mathrm{\mu g} / \mathrm{m}^{3} \mathrm{PH} / \mathrm{o}$ (particles with aerodynamic diameter smaller than or equal to a nominal 10 micrometers) (Federal Register 1984).

(c) Annual dispersiun factors are based on 3-5 km from facility (Appendix B).

(d) Concentrations of pollutants from construction (diesel exhaust) are based on ground-level releases, emission factors for heavy-duty diesel equipment and consumption of $10,000 \mathrm{gal}$ of fuel per month.

(e) Operational emissions are mainly from steam boilers. Concentrations of nonmethane hydrocarbons, mostly unburned diesel fuel, are negligible.

The facility design calls for a secondary water supply from a surface water source in case the main supply is cut off temporarily. Adequate surface water supplies are found within $10 \mathrm{~km}$ of both the warm-wet and cold-wet sites. The nearest source of water is about $25 \mathrm{~km}$ from the arid site (Table 3.2 ). The impact of using surface water is specific to the site and resources available.

Effiuent Source Terms. The MRS facility is designed so that there will be no radioactive waterborne effluents originating fron processing. The major waste water streams during operation are process waste water $(77,000 \mathrm{gpd})$ arlo sanitary waste $(14,000 \mathrm{gpd})$.

Cooling tower blowdown (a) accounts for most of the process waste water during the waste loading phase of operation. Orains, boiler blowdown, and filter backwash make up the remainder. An additional $70,000 \mathrm{gpd}$ is lost to the atmosphere as evaporation and cooling tower drift and thus does not contribute to the waste water load. Process waste water from cask-forming operations at the concrete sturage cask type facility amount to $1,500 \mathrm{gpd}$. Very little process water will be required during the storage-only phase of

(a) blowdown $=$ the water that is purged from the systeil and is then replaced with fresh water to prevent buildup of chenicals in the system. 
facility operation. The unloading operation should require less process water than the initial loading operation, since no package processing (consolidation) is required and less heat is generated by the aged fuel.

Effluent Treatment and Disposal. Process waste water undergoes several treatment steps prior to discharge. First the waste is neutralized, which reduces corrosivity and cawses precipitation of metais. A polymer flocculation aid is added, and the waste is clarified. The resulting sludge is dewatered, and the liquid is pressure filtered. Purified process waste water is released to the process waste drain field. Sludge from this process is disposed of at an appropriate waste site, depending on the chemical content of the sludge. Process sewage treatment equipment is sized for 3,600 MTU throughput flaws.

Sanitary waste is treated with a biological system consisting of two separate septic tanks and drainfieids, One system serves the R\&H facility and the cask manufacturing plant, while the other systern serves the administration and other service buildings. The operator may switch betweer independelit drainfields associated with each tank to prevent overloading.

Regulations and Permits. Discharge of waste water into waters of the United States is regulated by the EPA. At the arid Site, which has no surface streams, waste water woulo seep into the ground or evaporate. At a wet site, the effluent stream may join existing surface waters. The MRS facility may be required to obtain a permit from the National Pollutant Discharge Elimination System (NPDES), as required in 40 CFR 122. Several effluent characteristics must be monitored and reported (40 CFR 122.53).

Substances that may be hazardous in terms of water pollution are listed in 40 CFR 116, "Designation of Hazardous Substances." quantities of these materiais that may be harmful are 1isted in 40 CFR 117 , "Determination of Reportable Quantities for Hazardous Substances. Compounds used at the facjlity that may be hazardous are listed in Table 4.13. The projected use rate and the reportable amcunt from 40 CFR II7, if applicable, are also given. These materials are not wastes, but process chemicals. Process water is treated, and waste products are solidified and disposed of in an appropriate facility. None of the toxic substances listed in 40 CFR 129, "Toxic Pollutant Effluent Standards," are to be used in an MRS facility.

TABLE 4.13. Chenical Compounds to be Used at an MRS Facility

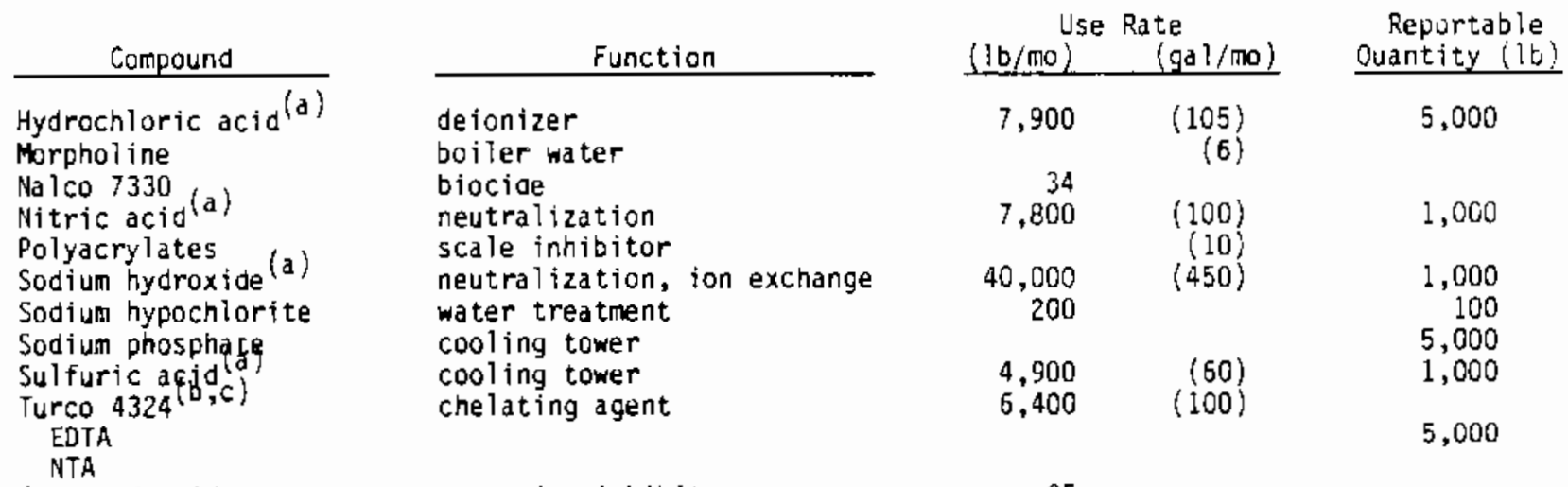

Zinc hydroxide

corrosion inhibitor

95

(a) Lse rate in $1 \mathrm{~b}$ is based on volume use rate and density for $40 \%$ aqueous solution.

(b) Turco 4324 is a proprietary decontamination solution containing EDTA and NTA.

(c) Use rate in lb is based on volume use rate and density for a 6\% solution of EDTA.

Accidents. It is unlikely that accidents could affect surface or ground water, since waste handijng is done inside the R\&H facility. Waste spillage caused by equipment failure or operator error will be contained and treated within the building.

\subsubsection{Decomissioning Activities}

Decomissioning should require little water compared with operation. Cooling water, important during operation of the R\&H facility, should only be a small factor after fuel is removed in the unloading (operational) phase of the project. Process waste water will be generated by boilers and decontamination systems, but the water consumption rate will be lower than during operation.

At a sealed storage cask type facility, casks are noved into the R\&H facility to be unloaded and decontaminated if necessary. At a ffeld drywell type facility, drywells are decontaninated, if necessary, with a portable decontamination system. Spent decontanifnation liquids are collected in a tank truck and transported to the R\&H facility liquid radwaste system for processing. An acciderit could thus involve 
spillage of decontamination solutions from the tank truck outside the R\&h facility. Such a spill involving radioactive contamination would be cleaned up rapidiy and have negligible nonradiological impact.

\subsubsection{Transportation Activities}

Routine trassport of materials to and from the facility should cause no waterborne effluents. Transport accidents could possibiy involve contanination of water with process chemicals destined for the facility. For several compounds that are in common use in industry, the projected monthly use rate at the MRS facility exceeds the reportable quantity (Table 4.13). An accident would be reportable if the shipment were, for instance, spilled into a river. Transporting common industrial chemicals to the MRS facility poses no greater risk than nomal commerce.

\subsubsection{Sunmary}

Water use rates during the construction, operation, and decommissicning phases of the proposed MRS factility types at each of the three reference sites are compared in Table 4.14. The MRs facility has its greatest impact on water resources during its operating phase. The water requirements of an MRS facility do not place unreasonable demands on water resources for most locations. However, the avaitability of water and pernits to use water are important factors to be considered in siting an MRS facility. Insufficient water or che inability to obtain permits may preclude siting an MRS facility in some arid locations.

Discharges of any materials containing hazardous compounds will be prevented because decontamination wastes are to be solidified and packaged for disposal. Waste water streams undergo extensive cleanup before discharge. Thus, the proposed MRS facility is not expected to have any adverse impact un drinking or surface water. The disposal of high quality treated water is unlikely to be an environniental concern.

TABLE 4.14. Maximum Water Use Rate $\left(10^{3} \mathrm{gpd}\right)$ During Construction, Operation, and Decommissioning at an MRS Facility

\begin{tabular}{|c|c|c|c|c|c|c|}
\hline \multirow[b]{2}{*}{ Activity } & \multicolumn{3}{|c|}{ Sealed Storage Cask } & \multicolumn{3}{|c|}{ Field Drywell } \\
\hline & Arid & Warm let & Coid wet & Arid & Warm Wet & Cold wet \\
\hline $\begin{array}{l}\text { Construction (a) } \\
\text { Operation } \\
\text { Decomissioning }\end{array}$ & $\begin{array}{r}50 \\
210 \\
10\end{array}$ & $\begin{array}{r}20 \\
210 \\
10\end{array}$ & $\begin{array}{r}20 \\
200 \\
10\end{array}$ & $\begin{array}{r}50 \\
205 \\
10\end{array}$ & $\begin{array}{r}20 \\
205 \\
10\end{array}$ & $\begin{array}{r}20 \\
195 \\
10\end{array}$ \\
\hline
\end{tabular}

(a) Construction use rate is based un $10 \mathrm{million}$ gallons during 5 years of construction, with maxinum use of three times the average rate. In addition, water for dust control is estimated to average $30,000 \mathrm{gpd}$ at the arid site and $3,000 \mathrm{gpd}$ at the wet sicts.

\subsection{LAND USE IMPACTS}

This section describes the impacts of an MRS facility on land use for ail site/concept combinations.

\subsubsection{Construction Activities}

For the arid site, construction of an MRS facility will result in the withdrawal of approximately 200 acres for a sealed storage cask facility and approximately 350 acres for a field drywell facility of shrub-steppe desert land frum natural processes. Ouring site preparation, the upper 2 feet of loose soil will be excavated and refilled with material that will be compacted to support the site facilities. Disposal of the excavated soil could cause further impacts, depending upon how and where it is disposed. This soil could eventually provide plant and animal habitat once it has stabilized; however, it is likely that new vegetation would not be similar to the pristine vegetative cover since disturbed sites in this region are mure likely to be invaced by such plants as cheatgrass and Russian thistle. Care must be taken to avoid and/or preserve any archeological sites encountered.

For the warm-wet site and the cold-wet site, construction impacts on land use will be similar to those at the arid site. However, natural restoration of the original vegetative cover is more likely at the wet sites.

\subsubsection{Operation Activities}

Facility operations should have minimal additional land use impacts. Liquid wastes generated during uperation will be disposed of on site by evaporation or filtration. 


\subsubsection{Decomissioning Activities}

Decomissioning of the facility will result in no significant additional impact to land use unless new roads, etc., are constructed for deconmissioning.

\subsubsection{Sumary}

Clearing the land for site construction will be more difficult at the warm-wet and cold-wet sites because they have more vegetative cover that must be removed. This is probably must true for the wamn-wet site. The field arywell concept will have the greatest land use impact because more land is needed. Land use impacts from operations should be similar at all site/concept combinations. If restoration is considered during deconimissioning, impacts will be similar to those described for construction. Restoration of land to its original state will probably be easier at both the warm-wet and cold-wet sites because of more precipitation aria better overall growing conditions. This shcula be true for the establishment of a general vegetative cover; however, reestablishment of the original cover of trees, etc., will take much. ionger. Land use impacts (e.g., withdrawal of lano and wildife harrassnent) from transportation are expected to be sinilar at all site/concept combinations.

\subsection{BIOLOGICAL IMPACTS}

This section includes the potential impacts of various site activities on plant and animal populations, including endangered species, and their habitats.

\subsubsection{Construction Activities}

An MRS facility at the arid site will take about 200 to 350 acres as described above. Natural vegetation and animal habitat on this land will be lost, including nesting sites for birds, gruind cover for small animais and reptiles, and burrowing habitat for small mamals, reptiles and insects. Destruction of the vegetative cover will result in a loss of primary production of the plants and a subsequent loss ot this material for higher trophic levels that may use it, either directly as food or inairectly after mineralization. Disposal of excavated soil may further impact other areas, although the displaced soil could become suitable plant and animal habitat after it has stabilized. It may be possible to pronote revegetation by enhancing the displaced soil using fertilizers or other methods to aid plant growth.

During construction, accidental brush fires could burn the vegetative cover of the surrounding land. impacts are unpredictable and would depend on the extent of the fire prior to its control.

Construction activities, including noise, will tend to drive away some species, aithough most of this may be tesluorary and will depend on the habits and adaptability of the animals in question. Facility effluents are negligible and should not be a problem during construction.

No impacts on rare or endangered species should occur as long as the selected area does not include habitat occupied or used by these species.

Impacts associated with construction at the warm-wet site will be similar to those for the arid site, except the amount of primary productivity associated with the loss of vegetation at the waril-wet site wit be considerably more than that at the arid site. Vegetation removal will likely involve the loss of trees at this site; trees were essentially absent at the arid site. Displacement of reptiles and amphibians miay also be greater at this site because these animals are yenerally more prevalent. Additional care wili need to be exercised to avoid impacts to rare and endangered birds and the American alligator; for example, two nesting birds--the redcockaded woodpecker and Kirtland's warbler--live in the wanm-wet area.

Impacts at the cold-wet site will be similar to those at the arid site, except site construction will result in the loss of agricuttural produce from row-crop land. Some trees may also be lost during construction at this site.

\subsubsection{Operation Activities}

Operation of an MRS facility will have little additional impact on plant and animal populations. Liquid effluents are processed by evaporation or filtration and disposed of on site. Water for operation will be derived from onsite wells, thus will not impact surface waters. Should water need to be withdrawn from nearby surface supplias, then ecological impacts may occur to the aquatic ecosystems, depending on the rate and amount of water used and the ecological characteristics of the lake or river supplying the water.

Noise impacts and perturbations due to movement of people and fiachinery should not exceed those typical of an industrial operation of this size. 


\subsubsection{Decomissioning Activities}

Decormissioning of an MRS facility should cause little, if any, additional impact on terrestrial or aquatic ecosystems; additional harassment caused by increased noise and equipment activity will be temporary. Al though not presently contemplated, decommissioning could involve the removal of all buildings and structures; then it might be beneficial and/or necessary to restore the natural land contours and revegetate the site. Revegetation could include enhancing the soil by using fertilizers or other methods of promoting plant growth.

\subsubsection{Transportation Activities}

Impacts caused by traffic will be slight and restricted to noise and rovement dlong the roads ana railways. This may cause some harassment to wildi ife. Road kills of wildiffe will probably occur. However, the magnitude of this loss will be dependent upon several variables, including density and species of wildife, temporal factors, traffic density, location of site, etc. Impact niay be mitigated by drivers' education programs, signs, fences, and other appropriate measures.

\section{5 .5 Summary}

Construction impacts $w i 11$ be greatest at the sites with more biota, both animals and vegetation. Removal of the vegetation will result in a greater loss of primary production and habitat at these sites. Reptile and amphibian loss may potentially have an impact on threatened or enaangered species and will be greatest at the warm-wet site. Overall impacts should be similar at ail site/concept combinations. However, general disturbance of wildlife by the presence and activities of workers and machinery will be greatest at the warm-wet and cold-wet sites where more wildlife is present. Decommissioning and transportation should have little additional biological impact.

\subsection{SOCIOECONOMIC IMPACTS}

Any project that affects the employment, income, population, resources, social services infrastructure, or public sector of a community has patential socioeconomic impacts. Constructing, operating, and decomissioning an MRS factlity require labor, materials, and services that must be supplied by existirig area resources or miust be imported to the site area. The potential impacts on a community from these resource requirements are analyzed in this section for each stage of an MRS facility. In aodition, because of its special nuclear nature, the MRS facility may have special impacts on the communities nearby. This is discussea in Section 4.6.4.

These estimated impacts are based on average data for U.S. arid, warm-wet, and cold-wet sites. The reference sites span a variety of socioeconomic conditions characterized by:

arid site: small, isolated, growing economy

cold-wet site: large, integrated, growing economy

warm-wet site: small, integrated, shrinking economy.

In this context, "integrated" means that the regional economy has inany links with the surrounding regional economies (through migration and trade). MRS impacts on the reference sites are computed through the Mietropolitan and State Economic Regions (MASTER) Model, City/County Allocation Model (CCAM), and Fiscal Inipact (FI) Model. The MASTER model is a regional impact model developed at PHL that generates est inates of employment, income, ano population for metropolitan statistical areas (MSAs) and counties. The CCAM and FI mudels use the MASTER economic output to generate estimates of other local socioeconomic impacts.

Because of the large anount of data generated by the modeis on inaividual communities over the life of an MRS facility, the figures reported in this section have been summarized. Representative years for each of the three stages of operation were chosen to approximate the high and low points in the MRS life cycle. These estimates of impacts on six affected socioeconomic categories are surmarized in Table 4.15 for sealea storage cask and Table 4.16 for drywell and are followed by discussions of the affectea categories. Socjoeconamic impaczs are slightly different for each year of the life of the MRS project. The periods of construction (1992-i997), operations (1997-2019), and decommissioning (2011-2021) overlap and encompass parts of 30 years (25-year operating 1 ife). It was not considered practical to show impacts for all years. Instead, this section reports results for the peak construction year (1996) where the impact was the highest, the peak decommissioning year (2019) where a secondary peak occurred, and the low point of the operations period (2010). Crdinarily, one would report the peak operation year, but the impact ouring the peak operations period was virtually the sabie as for construction for the sealed storage cask concept.

Employment impacts were estimated under the assumption that new jobs created in construction and operations (government) on the MRS project would go to local residents in the same proportions as new jobs historically have in these industries for the site. Since this was a reference-site analysis rather than a site-specific analysis, no assessinent was done of locally available skills. Population inipact is based on the historical average distribution of new jobs between resident and in-migrating labor. If the MRS project emplayed local residents only, the impacts would be smaller. If only in-migrants were employed at the 
project, the impact on population would be larger than shown. (Iure detajled information about the methodology used appears in Appendix C.)

More socioeconomic impacts are likely during the construction and decomissioning phases, because construction and decomissioning activities are projected to employ more people and purchase more services annually than operations. Many socioeconomic impacts are estimated for "centra T" and "noncentral" counties. A central county is the one that contains the MRS factlity. Other counties with most of their population living within a $50-m i l e(80-\mathrm{km})$ radius of the MRS facility comprise the noncentral courity impact area.

\subsubsection{Enployment and Income}

Mary of the socioeconomic impacts associated with an HRS facility stem directiy or irdirectly from the project's demands for labor, materiais, and services. If these cemands are filled outside the lacal area, socjueconomic impacts will te minimized. If these demands are filled within the Iocal area, socioeconomic impacts ircrease. The cycle of business spending and respending that follows primary (direct) employment and the resulting purchase of goods and services then leads to indirect employment. Spending of wages and profits by the region's residents induces still more employment, and the cycle repeats.

Constructing and operating an MRS also change the income levels of the surrounding area. Two factors influence this: 1) increased purchases at local businesses, and 2) wage rates of direct and indirect workers, as compared to average wage rates before construction.

Some impacts on employment and income would occur during the construction phase. About 400 to 700 workers will be needed during construction. Most of these direct jobs require crafts workers with specialized skills. Since most of the unemployed local workforce will not have these specialjzed skills, the construction jobs will be filled largely by newcomers or commuters. The average wage rate for MRS construction workers is estimated to be about $\$ 25.00$ per hour (1985\$), which is higher than the average construction wage rate prevailing in each area. Some job switching may occur in response to these higher wages; highly skilled local workers may be hired while less-skilled workers fili in the vacated jobs.

Indirect and induced jobs will also be created during construction; from 2.4 to 3.4 total jobs are created in the region per direct employee at the MRS site. Most of the indirect and induced jobs are in service and retail, and these can be filled with relativeily unskilled local labor. The nunber of indirect jobs created per direct HRS employee depends on these factors: design concept, reference site, time period, and county (central or noncentrai). The number of indirect jobs also depends un such factors as size of county, number of direct workers living in county, degree of integration, size and performance level of economy (stable, growing, declining), and role as a regional trade center. The two storage concepts differ in their labor and materials requirements over time. The three economies into which the MRS is introduced differ in the types and levels of services. Impacts differ between the central county and noncentral county at each site, depending on the location of other towns, of community services, and of businesses which serve the MRS facility and the region's residents. Wage rates for indirect workers are estimated to be about $\$ 15,00$ per hour, which is the same as the baseline general services wage rate.

During the operations and decomissioning phases, most of the job fmpacts are in the services and trade categories. About 600 workers will be employed during each of the first years of operation; this number decreases during the storage phase of operation. About 300 workers would be employed during the last years of decomissioning. Indirect employment is generally lower during these phases, since the level of investment per direct worker tends to be lower than during construction.

Income impacts come from the effects of increased purchases by both the MRS facility (for materials and services) and by workers and their families. On a per-capita basis, income is expected to rise so slightly (less than $\$ 50.00$ per capita) with the MRS effects as to be insignificant.

Figure 4.1 shows the timing of the total employment impact of the sealed storage cask facility by year at the three MRS sites. Direct MRS employnent is also shown in the figure for reference. The employment impacts are very similar at the arid and cold-wet sites, especially during the construction period (19921997). The arid site has a small economy, so that many goods and services are likely to be purchased outside the economy and contribute to employment elsewhere. The cold-wet site's economy is much larger, but at cold-wet sites such economies are frequently satellite econornies of major metropolitan areas. Thus, even though most goods and services are locally available, they still may be purchased at the nearby metropolitan area. In contrast, the warm wet site is quite large relative to most surrounding regional economies and is more likely to provide the services required. Thus, the wanti-wet reftrence site economy shows a larger total employment impact.

The employnent effects of the MRS facility vary between the two storage concepts because direct employment differs in both level and timing. In addition, the arnount and pattern of expenditures (which affect indirect employmenc) are also different. Figure 4.2 illustrates the difference between total employment impacts for the sealed sturage cask ano the fielo orywell at the cold-wet site. The figure shows that total empioyment impacts are 400-plus persons higher during construction (1992-1997) for the 
TABLE 4.15. Estimates of Socioeconomic Impacts, Sealed Storage Cask ${ }^{(a)}$

\begin{tabular}{|c|c|c|c|c|c|c|}
\hline \multirow[b]{2}{*}{ Site, Year, and Area } & \multicolumn{6}{|c|}{ Increase Over No MRS } \\
\hline & $\begin{array}{l}\text { Total } \\
\text { Employment } \\
\text { (persons) }\end{array}$ & $\begin{array}{c}\text { Total Income } \\
\text { (million } \\
1985 \$) \\
\end{array}$ & $\begin{array}{l}\text { Total } \\
\text { Population } \\
\text { Spersons) }\end{array}$ & $\begin{array}{l}\text { Oemand for } \\
\text { Housing } \\
\text { (units) } \\
\end{array}$ & $\begin{array}{l}\text { Public Revenues } \\
\text { (million 1985\$) }\end{array}$ & $\begin{array}{c}\text { Public Service } \\
\text { Expenditures } \\
\text { (million 1985 } 5 \text { ) }\end{array}$ \\
\hline $\begin{array}{l}\text { Arid Site } \\
\text { Peak Construction } \\
\text { Year (1996) } \\
\text { Central } \\
\text { Noncentral } \\
\text { Total }\end{array}$ & $\begin{array}{r}850 \\
250 \\
1,100\end{array}$ & $\begin{array}{r}27.2 \\
7.3 \\
34.5\end{array}$ & $\begin{array}{r}1,700 \\
450 \\
2,150\end{array}$ & $\begin{array}{l}600 \\
150 \\
750\end{array}$ & $\begin{array}{r}17.6 \\
4.4 \\
21.6\end{array}$ & $\begin{array}{r}10.5 \\
2.9 \\
13.4\end{array}$ \\
\hline $\begin{array}{l}\text { Lowest Operation } \\
\text { Year (2010) } \\
\text { Central } \\
\text { Noncentral } \\
\text { iotal }\end{array}$ & $\begin{array}{l}400 \\
100 \\
500\end{array}$ & $\begin{array}{r}15.2 \\
2.9 \\
18.1\end{array}$ & $\begin{array}{r}1,550 \\
200 \\
1,750\end{array}$ & $\begin{array}{r}550 \\
50 \\
600\end{array}$ & $\begin{array}{r}16.1 \\
1.7 \\
17.8\end{array}$ & $\begin{array}{r}10.8 \\
1.4 \\
12.2\end{array}$ \\
\hline $\begin{array}{l}\text { Peak Decommissioning } \\
\text { Year (2019) } \\
\text { Central } \\
\text { Noncentral } \\
\text { Total }\end{array}$ & $\begin{array}{r}850 \\
250 \\
1,100\end{array}$ & $\begin{array}{r}34.8 \\
6.9 \\
41.7\end{array}$ & $\begin{array}{r}2,600 \\
400 \\
3,000\end{array}$ & $\begin{array}{r}900 \\
150 \\
1,050\end{array}$ & $\begin{array}{r}26.8 \\
3.9 \\
30.7\end{array}$ & $\begin{array}{r}17.2 \\
2.5 \\
19.7\end{array}$ \\
\hline $\begin{array}{l}\text { Warmi-Wet Site } \\
\text { Peak Construction } \\
\text { Year (1996) } \\
\text { Central } \\
\text { ivoncentral } \\
\text { Total }\end{array}$ & $\begin{array}{r}150 \\
1,350 \\
1,500\end{array}$ & $\begin{array}{r}3.8 \\
40.3 \\
44.1\end{array}$ & $\begin{array}{r}150 \\
l, 550 \\
l, 700\end{array}$ & $\begin{array}{r}50 \\
750 \\
800\end{array}$ & $\begin{array}{r}0.8 \\
10.6 \\
11.4\end{array}$ & $\begin{array}{r}0.7 \\
9.7 \\
10.4\end{array}$ \\
\hline $\begin{array}{l}\text { Lowest Operation } \\
\text { Year (2010) } \\
\text { Central } \\
\text { Noncentra } 1 \\
\text { Total }\end{array}$ & $\begin{array}{r}50 \\
500 \\
550\end{array}$ & $\begin{array}{r}1.3 \\
18.3 \\
19.6\end{array}$ & $\begin{array}{r}50 \\
750 \\
800\end{array}$ & $\begin{array}{r}50 \\
250 \\
300\end{array}$ & $\begin{array}{l}0.4 \\
5.5 \\
5.9\end{array}$ & $\begin{array}{l}0.4 \\
5.4 \\
5.8\end{array}$ \\
\hline $\begin{array}{l}\text { Peak Decumissioning } \\
\text { Year (2019) } \\
\text { Central } \\
\text { iNonentra } 1 \\
\text { Tota } 1\end{array}$ & $\begin{array}{r}100 \\
1,050 \\
1,150\end{array}$ & $\begin{array}{r}3.4 \\
45.1 \\
48.5\end{array}$ & $\begin{array}{r}200 \\
1,500 \\
1,700\end{array}$ & $\begin{array}{r}50 \\
550 \\
600\end{array}$ & $\begin{array}{r}1.3 \\
10.3 \\
11.6\end{array}$ & $\begin{array}{r}1.0 \\
9.3 \\
10.3\end{array}$ \\
\hline $\begin{array}{l}\text { Cold-Wlet Site } \\
\text { Peak Construction } \\
\text { Year (1996) } \\
\text { Centra) } \\
\text { Voncentral } \\
\text { Total }\end{array}$ & $\begin{array}{r}100 \\
1,050 \\
1,150\end{array}$ & $\begin{array}{r}3.6 \\
33.1 \\
36.7\end{array}$ & $\begin{array}{r}300 \\
2,650 \\
2,950\end{array}$ & $\begin{array}{r}100 \\
950 \\
1,050\end{array}$ & $\begin{array}{r}1.0 \\
9.6 \\
10.6\end{array}$ & $\begin{array}{r}1.3 \\
12.5 \\
13.8\end{array}$ \\
\hline $\begin{array}{l}\text { Lowest Operation } \\
\text { Year (2010) } \\
\text { Central } \\
\text { Noncentral } \\
\text { Total }\end{array}$ & $\begin{array}{r}50 \\
350 \\
400\end{array}$ & $\begin{array}{l}1.1 \\
10.4 \\
11.5\end{array}$ & $\begin{array}{r}100 \\
1,100 \\
1,200\end{array}$ & $\begin{array}{r}50 \\
400 \\
450\end{array}$ & $\begin{array}{l}0.5 \\
4.8 \\
5.3\end{array}$ & $\begin{array}{l}0.7 \\
6.3 \\
7.0\end{array}$ \\
\hline $\begin{array}{l}\text { Peak Decommissioningl } \\
\text { Year (2019) } \\
\text { Central } \\
\text { Noncentral } \\
\text { Total }\end{array}$ & $\begin{array}{l}100 \\
850 \\
950\end{array}$ & $\begin{array}{r}2.6 \\
22.8 \\
25.4\end{array}$ & $\begin{array}{r}250 \\
2,100 \\
2,350\end{array}$ & $\begin{array}{l}100 \\
750 \\
850\end{array}$ & $\begin{array}{l}0.9 \\
7.4 \\
8.3\end{array}$ & $\begin{array}{r}1.2 \\
9.5 \\
10.7\end{array}$ \\
\hline
\end{tabular}

(a) These estimates include both primary and secondary impacts; the values are the differences between a baseline growth path (community growth without an MRS facility) and an MRS growth path (community growth with an MRS facility).

(b) Place-of-work basis.

(c) About half of the total employment estimate in the peak decommissioning year is for decommissioning activities. The remainder is for operations and maintenance activities that occur during this peak decomissioning year. 
TABLE 4.15. Estimates of Socioeconomic Impacts, Field Oryweli (a)

\begin{tabular}{|c|c|c|c|c|c|c|c|}
\hline Site, Year, and Area & $\begin{array}{l}\text { Total } \\
\text { Employment } \\
\text { (persons) }\end{array}$ & $\begin{array}{c}\text { Total lncome } \\
\text { (million } \\
1985 \$) \\
\end{array}$ & $\begin{array}{l}\text { Increase } 0 \\
\text { Total } \\
\text { Population } \\
\text { (persons) }\end{array}$ & $\begin{array}{l}\text { Jver No MRS } \\
\text { Demand for } \\
\text { Housing } \\
\text { (units) } \\
\end{array}$ & $\begin{array}{l}\text { Public Revenues } \\
\text { (million 1985s) }\end{array}$ & $\begin{array}{c}\text { Public Service } \\
\text { Expenditures } \\
\text { (milition 1985\$) }\end{array}$ & . \\
\hline $\begin{array}{l}\text { Arid Site } \\
\text { Peak Construction } \\
\text { Year (1996) } \\
\text { Central } \\
\text { Noncentral } \\
\text { Total }\end{array}$ & $\begin{array}{r}1,250 \\
350 \\
1,600\end{array}$ & $\begin{array}{l}38.6 \\
10.3 \\
48.9\end{array}$ & $\begin{array}{r}2,450 \\
650 \\
3,100\end{array}$ & $\begin{array}{r}900 \\
200 \\
1,100\end{array}$ & $\begin{array}{r}25.2 \\
6.3 \\
31.5\end{array}$ & $\begin{array}{r}15.7 \\
4.1 \\
19.8\end{array}$ & 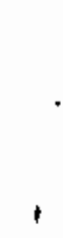 \\
\hline $\begin{array}{l}\text { Lowest Operation } \\
\text { Yedr (2010) } \\
\text { Central } \\
\text { Noncentral } \\
\text { Total }\end{array}$ & $\begin{array}{l}450 \\
100 \\
550\end{array}$ & $\begin{array}{r}16.9 \\
3.2 \\
20.1\end{array}$ & $\begin{array}{r}1,900 \\
200 \\
2,100\end{array}$ & $\begin{array}{r}650 \\
50 \\
700\end{array}$ & $\begin{array}{r}19.9 \\
2.1 \\
22.0\end{array}$ & $\begin{array}{l}13.1 \\
1.4 \\
14.5\end{array}$ & 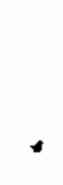 \\
\hline $\begin{array}{l}\text { Peak Decommissioning (c } \\
\text { Year }(2019) \\
\text { Centra } 1 \\
\text { Noncentral } \\
\text { Total }\end{array}$ & $\begin{array}{r}900 \\
250 \\
1,150\end{array}$ & $\begin{array}{r}37.9 \\
7.6 \\
45.5\end{array}$ & $\begin{array}{r}3,000 \\
400 \\
3,400\end{array}$ & $\begin{array}{l}I, 050 \\
150 \\
1,200\end{array}$ & $\begin{array}{r}30.4 \\
4.2 \\
34.6\end{array}$ & $\begin{array}{r}19.5 \\
2.6 \\
22.1\end{array}$ & \\
\hline $\begin{array}{l}\text { Warn-het Site } \\
\text { Peak Construction } \\
\text { Year (1996) } \\
\text { Central } \\
\text { Noncentra? } \\
\text { Total }\end{array}$ & $\begin{array}{r}200 \\
1,900 \\
2,100\end{array}$ & $\begin{array}{r}5.4 \\
57.0 \\
62.4\end{array}$ & $\begin{array}{r}200 \\
2,200 \\
2,400\end{array}$ & $\begin{array}{r}50 \\
750 \\
800\end{array}$ & $\begin{array}{l}1.2 \\
15.1 \\
16.3\end{array}$ & $\begin{array}{r}1.0 \\
13.7 \\
14.7\end{array}$ & \\
\hline $\begin{array}{l}\text { Luwest Operation } \\
\text { Year (2010) } \\
\text { Central } \\
\text { liuncentra } 1 \\
\text { Total }\end{array}$ & $\begin{array}{r}50 \\
550 \\
600\end{array}$ & $\begin{array}{r}1.5 \\
20.5 \\
22.0\end{array}$ & $\begin{array}{r}50 \\
800 \\
850\end{array}$ & $\begin{array}{r}50 \\
250 \\
300\end{array}$ & $\begin{array}{l}0.5 \\
6.0 \\
6.5\end{array}$ & $\begin{array}{l}0.4 \\
5.6 \\
6.0\end{array}$ & \\
\hline $\begin{array}{l}\text { Peak Oecormissioning (c } \\
\text { Year }(2019) \\
\text { Central } \\
\text { Noncentral } \\
\text { Total }\end{array}$ & $\begin{array}{r}100 \\
l, 150 \\
1,250\end{array}$ & $\begin{array}{r}3.6 \\
48.4 \\
52.0\end{array}$ & $\begin{array}{r}200 \\
1,600 \\
1,800\end{array}$ & $\begin{array}{r}50 \\
550 \\
600\end{array}$ & $\begin{array}{l}1.3 \\
10.6 \\
11.9\end{array}$ & $\begin{array}{r}1.0 \\
9.6 \\
10.6\end{array}$ & \\
\hline $\begin{array}{l}\text { Cold-wet Site } \\
\text { Peak Construction } \\
\text { Year (1996) } \\
\text { Central } \\
\text { NoncentraT } \\
\text { Total }\end{array}$ & $\begin{array}{r}150 \\
1,450 \\
1,600\end{array}$ & $\begin{array}{r}5.1 \\
47.0 \\
52.1\end{array}$ & $\begin{array}{r}400 \\
3,700 \\
4,100\end{array}$ & $\begin{array}{r}150 \\
1,350 \\
1,500\end{array}$ & $\begin{array}{l}1.5 \\
13.8 \\
15.3\end{array}$ & $\begin{array}{r}1.8 \\
21.0 \\
22.8\end{array}$ & \\
\hline $\begin{array}{l}\text { Lowest Operation } \\
\text { Year (2010) } \\
\text { Central } \\
\text { Noncentra } \\
\text { Total }\end{array}$ & $\begin{array}{r}50 \\
400 \\
450\end{array}$ & $\begin{array}{r}1.2 \\
11.1 \\
12.3\end{array}$ & $\begin{array}{r}150 \\
1,200 \\
1,350\end{array}$ & $\begin{array}{r}50 \\
450 \\
500\end{array}$ & $\begin{array}{l}0.5 \\
5.0 \\
5.5\end{array}$ & $\begin{array}{l}0.7 \\
6.3 \\
7.2\end{array}$ & \\
\hline $\begin{array}{l}\text { Peak Decommissioning (c } \\
\text { Year }(2019) \\
\text { Central } \\
\text { Noncentral } \\
\text { Total }\end{array}$ & $\begin{array}{r}100 \\
900 \\
1,000\end{array}$ & $\begin{array}{r}2.8 \\
25.0 \\
27.8\end{array}$ & $\begin{array}{r}250 \\
2,250 \\
2,500\end{array}$ & $\begin{array}{l}100 \\
800 \\
900\end{array}$ & $\begin{array}{l}1.0 \\
8.0 \\
9.0\end{array}$ & $\begin{array}{r}1.2 \\
10.3 \\
11.5\end{array}$ & \\
\hline
\end{tabular}

(a) These estinates include both primary and secondary impacts; the values are the differences between a baseline growth path (community growth without an MRS facility) and an MRS growth path (conmunity growth with an MRS facility).

(b) Place-of-work basis.

(c) About half of the total employment estimate in the peak decormissioning year is for decommissioning activities. The remainder is for operations and ma intenance activities that occur during this peak decomissioning year. 


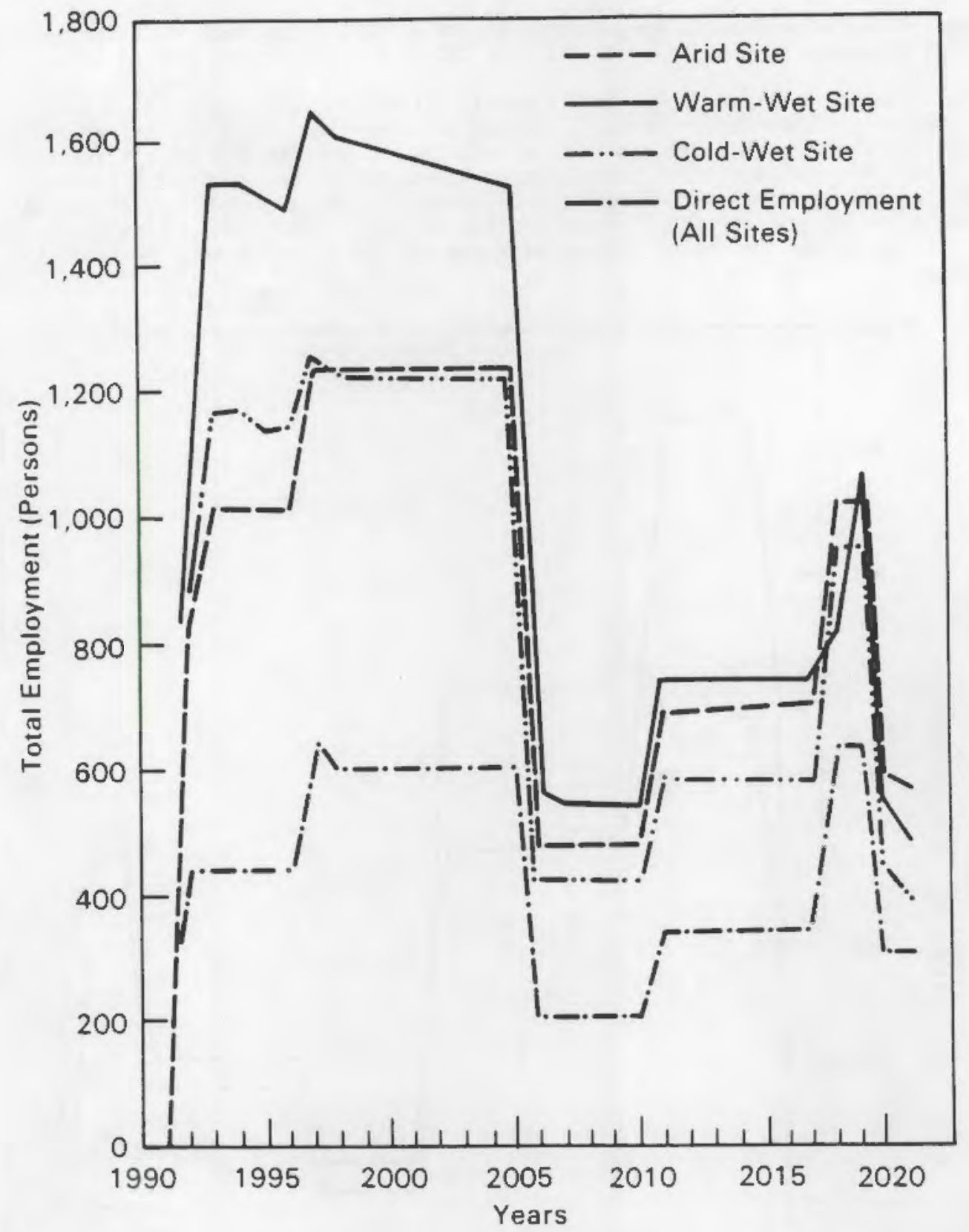

FIGURE 4.1. Total Employment Impacts of a Sealed Storage Cask Facility by Site

field drywell than for the sealed storage cask. However, cask manufacturing keeps employment at near construction-period levels between 1997 to 2005 for the sealed storage cask concept, whereas direct employment and investment falls more abruptly for the field drywell concept. Total employment impacts are not very different for different concepts and sites after the beginning of storage operations (year 2006).

\subsubsection{Population and Housing}

To predict population and housing impacts in any one year, MRS-related growth must be compared to growth that would have occurred anyway (baseline values). The MRS impact is then defined as the difference between the baseline values and the estimated values (with MRS) for a given year.

In this section, the changes in population and housing needs are reviewed for construction, operation, and decommissioning of an MRS facility at all three reference sites.

Population increases resulting from construction of an MRS facility are concentrated in the central county surrounding the plant at the arid site, while the new population is more dispersed at the other two 
reference sites. Population impacts are measured as the difference between the baseline population (without MRS) and the estimated population (with MRS) for the peak construction year of 1996.

The drywell concept generates more local economic activity during construction than does the sealed storage cask concept and therefore results in greater in-migration. The sites differ in the degree to which the local population is willing and able to join the labor force and the attractiveness of the area to migrants. Thus, for each additional job in its central çounty, the warmi-wet site gains one new resident, and the cold-wet site gains three new residents. (d) The forecasted total population increases during the peak construction year (1996) for the arid, warm-wet, and cold-wet sites are, respectively, $2,150,1,700$, and 2,950 for the sealed storage cask concept and $3,100,2,400$, and 4,150 for the field drywell concept.

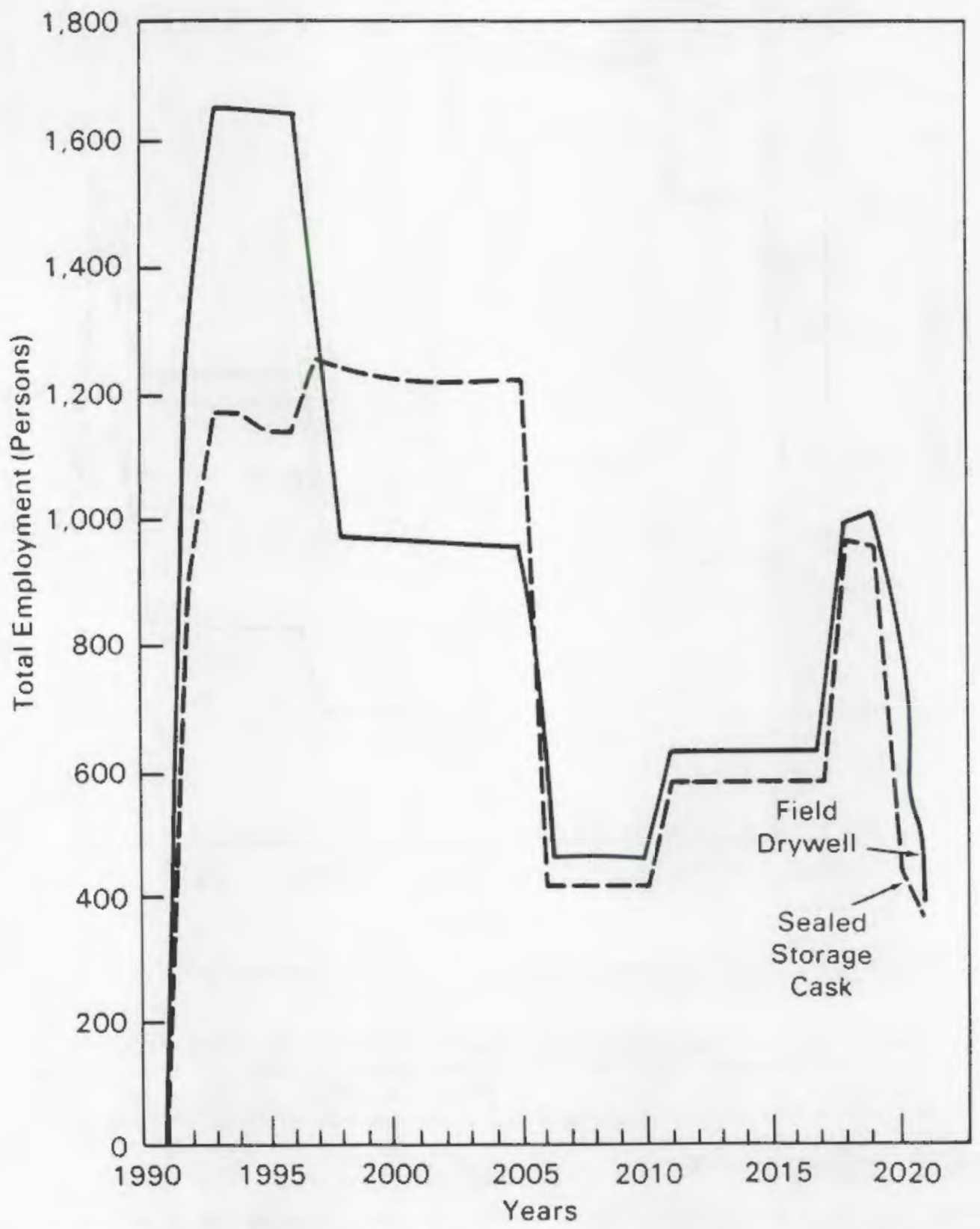

FIGURE 4.2. Total Employment Impacts of a Sealed Storage Cask Facility Versus a Field Orywell Facility, Cold-Wet Site

(a) It would seem that remote sites should generate more migration per job than more populated sites. However, more integrated economies, such as the cold-wet site, may gain more migrants because the migrants could move in from many large outlying regions that are only a short distance away. Under these circumstances, local residents may actualiy be hired first less often than local residents at more remote sites. 
The highest population increases during the peak construction year 1996 are about 1 . 18 of the baseline population for the arid site, $0.2 \%$ for the wamm-wet site, and $0.3 \%$ for the cold-wet site. About $39-41 \%$ of the corresponding MRS-related employment increase stems directly from plant construction at the arid site (29-31\% at the warm-wet site and $38-40 \%$ at the cold-wet site), while the remaining percentage is indirectly generated.

For the arid site, total population for the central county in 1996 is about 124,000 , which is 14.4 people per square nile. The noncentral county has a population of 153,000, or 7.7 people per square mile. Each of the two subregions of the study area has a city of approximately 50,000 people. The immigrating population will probably settle in the existing larger communities rather than focusing on the smaller towns closest to the construction site.

For the warm-wet site, the 1996 total population of the central county is about 133,000, or 79 people per square mile. The noncentral county has a population of 910,000 , or 106 people per square mile. Many of the people live in small towns and rural areas. There are several cities of 15 , C00 and two cities of 100,000 or more in the study area. The immigrating population for construction of an MRS facility will probably settle in the large towns and small cities nearest the site.

For the cold-wet site, the 1996 total population of the central county is about $161,000,0 \mathrm{r} 141$ people per square mile. The noncentral county population is about 2,710,000, or 230 people per square mile. Many of the people live in small or medium-sized towns. There are several small cities of about 20,000 and at least one large city of over 100,000 within commuting distance of the facility. The immigrating population for construction of an MRS facility will probably settle in the large towns and smali cities nearest the site.

The age and sex distribution of the study area population, particularly in the central county, changes only slightly during the construction period. The number of persons below the age of 35 increases slightly as young construction workers and their dependents move into the area. The number of males would increase faster than the number of females, since more of the construction workers are male.

Constructing, operating, and decomissioning an MRS also affects housing at each reference site. Housing impacts, like population impacts, are measured by comparing growth (with MRS) to growth that would have occurred anyway (without MRS).

\section{Construction}

At the arid site, the historical vacancy rate is $3 \%$, a) The vacancy rate for all housing units in the central county decreases, while total housing units demanded increases by about 600 units. The demand in the noncentral county increases by 150 units during the peak construction year. The combined dentand in both regions increases by 750 units. The total number of rental units is 26,350 for the peak curstruction year, a slight incredse over the baseline levels; the number of mobile homes grows slightly. Some of the seasunal homes near the site may be used as year-round rentals during this phase. Impacts are about 50\% larger for the field drywell concept.

At the warm-wet site, the historical vacancy rate is $8 \%$, (a) The vacancy rate for all housing units in the central county decreases while total housing units demanded increases by 50 units. This difference from the arid site is caused by the fact that the most attractive communities at the wanm-wet reference site are in the noncentral county. (See Appendix 0 for an explanation of the allocation procedure for population.) Total housing demand increases by 750 units in the noncentral county. The combined demand in both regions increases by 800 units. The total number of rental units is 60,950 for the peak construction year, a slight increase over the baseline; the number of mobile homes grows very little. Impacts are about $50 \%$ larger for the field drywell concept.

At the cold-wet site, the historical vacancy rate is $5 \%$ (d) The vacancy rate for all housing units in the central county of the cold-wet site decreases during this phase. Hoosing units demanded increases by 100 units in the central county and by 950 units in the noncentral county. Combined demand increases by 1,050 units. Because of the large amount of available housing, there is ijt te need for temporary housing. such as rental units and mobile homes. The total number of rental units is 258,500 for the peak construction year, an increase of 150 units over baseline; the number of mobile homes increases slightly. Impacts are about $50^{\circ}$ larger for the drywell concept.

\section{Operation}

Once the MRS facility is constructed, some construction workers leave the area. Direct and indirect jobs associated with the operations phase are more pemanent, resulting in an increased demand for pemanent housing and a decreased denand for temporary housing.

For the arid site, total demand for housing units in the year 2010 is higher than the baseline by 550 units in the central county and by 50 units in the noncentral county. This represents a decrease from

\footnotetext{
(a) 1980 Census of Housing.
} 
the 1996 peak of almost 150 units. If the population of the region is growing, however, this reduction in demand for housing could be absorbed by community growth.

For the warm-wet site, total housing units demanded increase by 50 units over baseline in the central county and by 250 units in the noncentra county. This represents a decline of 500 units from the 1996 peak. A shrinking economy would not be abie to absorb this many units; this would result in adverse impacts on the housing market.

For the cold-wet site, total housing units demanded are higher than the baseline by 50 units in the central county and by 400 units in the noncentral county. This represents a 500 -unit decrease from the 1996 peak; but, because the population of this region is so large, it should be able to absorb this many units.

\section{Decomissioning}

The socioeconomic impacts of decommissioning on housing are measured by increases in the demand for units because the number of units demanded would rise to a level near the highest housing demands during MRS construction. This would be followed by a sharp decline in demand as decommissioning is completed. Decomissioning would require far more workers than operations, so the vacancy rates will decrease for both rental and owned housing units.

For the arid site, the impact on total units demanded increases by 1,050 units compared with the baseline vacancy rate for the year 2019, and the vacancy rates for rental units decrease. For the warm-wet sjte, total units demanded increase by 600 units compared with the baseline. In this economy, employment growth is slow, more people already housed in the region are drawn into the labor force, and fewer houses are needed for new migrants. For the cold-wet site, total units demanded increase by 850 units over the baseline.

\subsubsection{Public Revenues and Public Service Expenditures}

In this section, the fiscal impact of the HRS on the state and local govemments (counties, cities, school districts) is examined. Local government revenues are composed of intergovernitental transfers of funds from federai and state governments, own sources of revenues such as taxes and fees, and miscellaneous charges and special assessments. Public service recipients of local government expenditures include:

- public education

- public libraries

- public welfare services

- public health services other than hospitals

- hospitals

- highways

- sewage systens

- police protection

- fire protection

- correction facilities and services

- utilities (water, electric, gas and transit)

- natural resources (county activities for the pronotion of agriculture and conservation and protection of natural resources)

- parks and recreation

- miscellaneous.

It is necessary to determine whether the state and local government revenue base woulo be adequate to provide the increased public services required for the influx of MRS-related residents. A per capita or per user method of estimating revenues and expenditures is employed because it uses readily available historical data. The MASTER model and the CCAM/FI models provide the projections of revenues and service demands based only on per capita demand. (Tax rates, service charges, and service demand shares uf total expenditures were heid constant.) However, the future demand for public services will not only be determined by the number of new people entering the local ared, but by the capacity of existing systems to handle the increased demand and by the quality and availability of services required by the new residents.

Data are provided for a baseline projection (without MRS) so that the incremental fiscal impact of the facility on local government can be estinated. The last two columns in Tables 4.15 and 4.16 summarize the results for three representative years: 1996, 2010, and 2019. The total revenue and expenditure estinates represent a very small increase over baseline projections. Since there is generally a positive revenue balance, the revenue base would probably be adequate to meet the public sector service demands during the peak employinent year.

The impact on revenues and expenditures of state and local govemment varies considerably among storage concepts and reference sites. For example, revenue impacts in the peak construction year (1996) vary from $\$ 10.6$ million at the cold-wet site for the sealed storage cask concept to $\$ 31.5$ million at the 
arid site for the field drywell concept. The difference arises partiy because the migration rate required to fill the jobs created by MRS varies by site and concept; in addition, the political jurisdictions at each site collect different amounts of revenue per captta. Since any real site's tax base is unique, the levels of revenue at any specific site would be different from those levels reported in Tables 4.15 and 4.16. However, the reference site estimates should provide a general idea of the combined level uf state and local revenues at a real site. Similariy, expenditures per capita vary among reference sites and storage cuncepts over time. Examples of both positive and negative net fiscal impact are given in Tables 4.15 arid 4.16 .

in this reference-site analysis, total expenditures were assumed to increase proportiunately with the population. To determine the net fiscal impact of the MRS on a specific state and lacal government, site-specific data would be required.

The liRS would also have an impact on comminity services and facilities. These inciude Education, welfare, health care, highways, sewage systens, poilice and fire prutection, correction faci]ities, utilities, natural resources, and parks and recreation.

The following analysis describes the impact on commuity services at the central-county/noncentralcounty level. The central county contains the MRS facility. The noncentral county area is cumprised of al1 other counties with most of their populations living within a $50-m i l e(80-k m)$ ragius of the MRS facility. At a real site, the exact lacation of associatea population increases would in part determine whether individual communities would experience shortages of key comunity facilities or services. This analysis does not consider individual comunities at a reference site, since no detailed information about comunity facilities was available. Therefore, this discussion may understate the potential for adverse impact at a real site.

Public Education. For the arid site, the 1980 student enrollment in the tutal impact area is estimated tu be 52,000 in grades $k$ through 12. Baseline projections for the peak construction year (1996) estimate total enrollment would be about 66,000. With additional population fron MRS, enrolinent is estimated to increase by about 400 students. Since the capacity of existing and planned facilities is 24 students per room, the stuoent enroliment associated with MRS would require an additional 17 classroons equivalent. If individual schools were at or near capacity, individual school districts micht have to take action to transfer students to other schools, bring in temporary classrooms, double-shift students, accept larger class sizes, or take other measures to meet new enroliment. If schools are not at capacity, new investment nay not be required. Depending on the distribution of students among schools and the actions of administrators, staffing levels may or may not change.

For the warm-wet site, the 1980 student enrollment in the total impact area was assumed to be 195,060 in grades $K$ through 12 . Baseline projections for the peak construction year (1996) estimate total enrollment to be about 270,000. With additional population from MRS, enrollment is estimated to increase by about 300 students because of luwer migration at the warm-wet site. At 24 students per room, the student enrollment associated with MRS would require 12 additional classrooms. This might not result in new facilities, however, for the same reasons as above.

For the cold-wet site, the student enrollment in the total impact area was assumed to be 324,100 in grades $K$ through 12 . Baseline projections for the peak construction year (1996) estimate total enrollment will be 455,000 . With additiona? population from MRS, enroliment is estimated to increase by 500 students. At 24 students per room, the student enroliment associated with MRS would require 21 new classrooms. Depending on the distribution of students among facjlities, this may or may not require new capital investment, for the same reasons as mentioned above.

Public Welfare. Cash assistance for public welfare is assumed to remain constant per person over time, but must be adjusted for inflation (currently estimateo at 6\% per year). Any increase in total payments required from MRS-related population shifts will not require new facilities or employees.

For the arid site, in 1996, the number of persons living below the official federal poverty line is estimated to be 56,100 for the baseline projection and 56,500 for the MRS projectiun, about $20 \%$ of the region's population. In 2010, the baseline estimate is 47,850 and the MRS estimate is 47, 900 . In 2019 , the baseline is 84,700 and the MRS estimate is 85,300 . Since the MRS project would presumably increase the economic base of the community, reducing unemployment and increasing local incomes, it is possible that the percentage of persons living in poverty woulo diminish. However, if speculative migration into the region uccurs (i.e., if people migrate in anticipation of employment) and if these newly arrived speculative migrants tend to be unemployed, then poverty rates may decline by less than might otherwise be supposed, The impacts would probably be different for the two storage concepts since the population impacts are different. If the level of cash assistance were constant and the proportion of poor people in the population were unchanged, the sealed storage cask concept would result in an additional 400 people in poverty (700 for drywell) during peak construction, 100 during the low operations year 20i0, and 500 during decommissioning. This is on ly about a $1 \%$ increase over the projected poor population during construction, $0.1 \%$ in the low operating year, and $0.6_{\%}^{\circ}$ during decommissioning. Depending on economic conditions at the site when the MRS is built, the results for a real site could be considerably different. However, increases in 
numbers of poor of the magnitude shown probably would not significantly affect the combined welfare agencies of the local and state governments in the region.

For the warm-wet site in 1996, the annual average number of people living below the poverty 1 ine is estimated to be 257,200 , almost $25 \%$ of the population. In 1996 with a sealed storage cask MRS, that number is estimated to be 400 persons $(0.1 \%$ ) larger. The drywell impact is larger during construction (600 persons) but still not significant. The level of impact for both storage concepts is about 200 additional poor persons during the low operating year, and about 450 persons for both concepts during the peak of decomissioning. It is assumed that the percentage of the population below the poverty line stays constant at about $25 \%$. At a real site the number of poor could actually increase or decrease, depending on the degree of unsuccessful speculative migration.

At the cold-wet site in 1996, the annual average number of people below the poverty 1 ine is 257,000 , or 9\% of the population. With an MRS facility, that number is estimated to increase by 250 . In 2010 , the difference between baseline and MRS estinlates is 100. In 2019, the baseline and MRS projections differ by 200. These differences are insignificant. As at the arid site and warm-wet site, the underlying assumption is that poverty rates would not change as a result of MRS. If poverty rates decline the number of poor could grow less than shown here or actually decline. Impacts for the field drywell concept are slightly larger, but still not significant.

Health Care and Hospitals. In the central county of the arid site in 1996, there are estimated to be 5 acute-care hospitals with 385 beds. Table 4.17 shows the 1996 ratio of beds to population to be estimated at 3.1 per 1,000 people, which is below the current national average of 4,0 per 1,000 people. The noncentral county has 12 more hospitals with 390 beds.

Eighty-five physicians are assuned to be in the central county in 1996 with a physician-to-population ratio of 0.7 per 1,000 people. There would be 35 dentists available or 0.3 per 1,000 people. The area has been classified as medically underserved by the Secretary of Health, Education, anc welfare. The noncentral county has an additional 130 doctors and 45 dentists.

Anbulance service in the central county in 1996 would be provided by district fire departments with 15 vehicles (0.1 per 1,000 people), 35 aualified full-time emergency medical technicians, and part-time volunteers. Since the national average ratios are 0.2 vehicles per 1,000 people and 2 technicians per 1,000 people, the central impact area is below those averages.

IABLE 4.17. Central County Population-Related Health Care Demand Estimates During MRS Construction, Operation, and Decomissioning

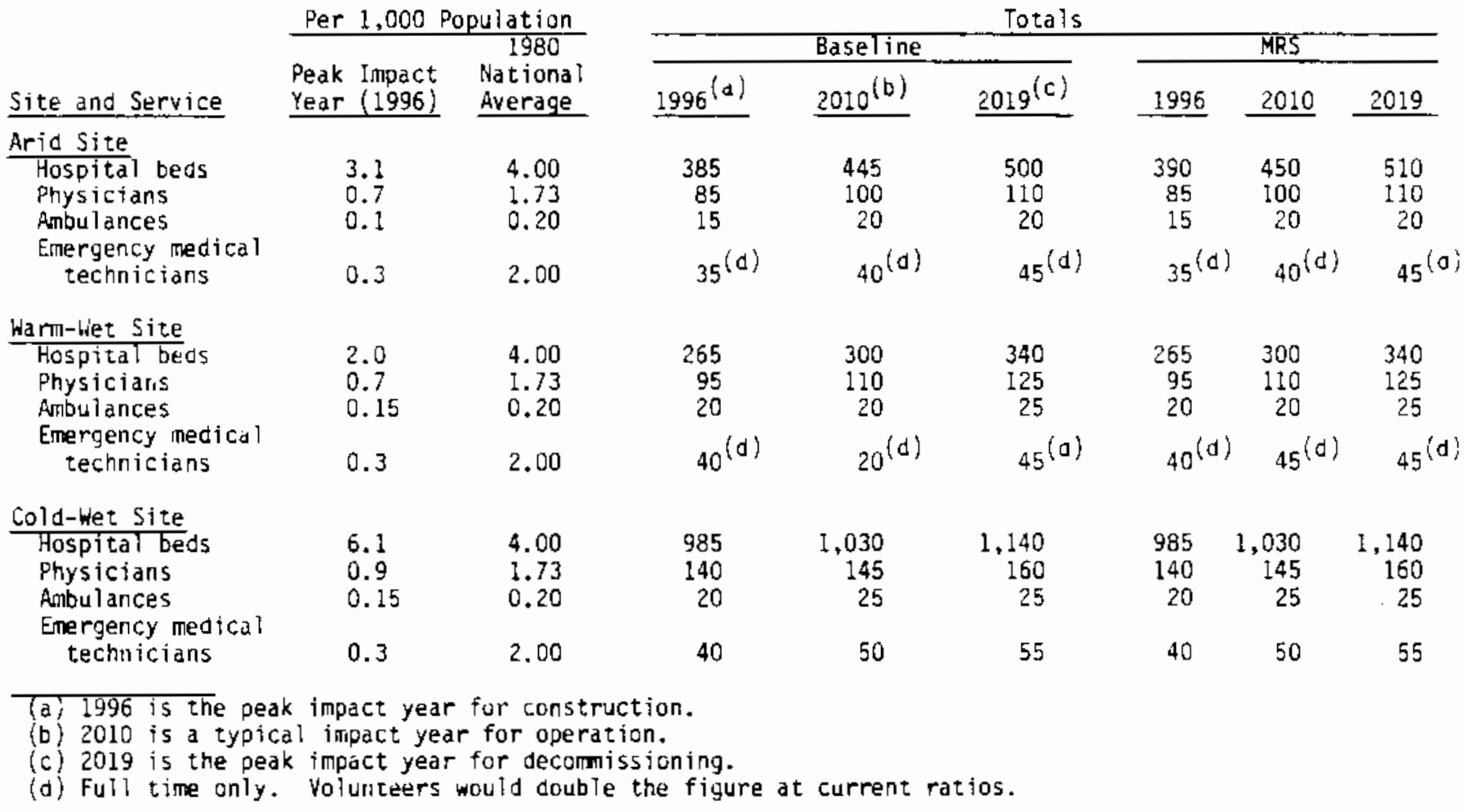


Population-growth-related changes would occur during the period 1992-2021 in selected health care requirements for local residents in the central county even at underserved rates (baseline estimates are provided for comparison). The impact of additional population from MRS activities would not significantly affect the required number of hospital beds, physicians, medical techricians, and ambulances. Any additional capital outlay for new facilities and additional hiring of new staff would depend on policies to operate on underserved status and whether revenue is available to make additions.

For the central county of the warm-wet site in 1996, 2 acute-care hospitals are assuned to be present with 265 beds. There are also severai nursing homes, intemediate-care facilities, clinics, and pharmactes. The 1996 ratio of beds to population is estimated at 2.0 per 1,000 people, below the current national average of 4.0 per 1,000 people. The surrounding counties in the noncentral area contain another 27 hospitals with 5900 beds in 1996. Emergency medical care is generally avatlabie in the region, but special nuclear-related facilities may have to be provided.

Ambulance service in the central county in 1996 would be provided by cities and aistrict fire departments having 20 vehicles ( 0.15 per 1,000 people), 40 qualified full-time emergency medical technicians (0.3 per 1,000 peuple) and additional part-time volunteers. Since the national average ratios are 0.2 vehicles per 1,000 people and 2 technicians per 1,000 people, the central impact area would be below those averages.

Population growth-related changes would occur during the period 1992-2021 in selected health care requirements provided to local residents in the central county, using current (underserved) rates. Table 4.17 shows that baseline estimates are below national service standards for all categories in 1996 , 2010, and 2019. Additional capital outlay and staff hires would depend on what level of service decision makers wish to provide and whether revenue is available to make additions.

For the central county of the cold-wet site in 1996, 7 acute-care hospitais are assumed to be present with 985 beds. There are also several nursing homes, intermediate-care facilities, clinics, and pharmacies. The 1996 ratio of beds to population is estinlated at 6.1 per 1,000 people, well above the national average of 4.0 per 1,000 people. The surrounding counties in the noncentral area contain another 66 hospitals with 17,700 beds in 1996. Emergency medical care is generally available in the region.

Ambulance service in the central county in 1996 would be provided by numerous incorporatec cities and district fire departments having 20 vehicles (0.15 per 1,000 people), 40 qualified full-time emergency medical technicians $(0.3$ per 1,000 people) and additional part-time volunteers. Since the national average ratios are 0.2 vehicles and 2 technicians per 1,000 people, the central impact area is below average.

Population growth-related changes are shown in Table 4.17 for selected health care inputs that would cccur over the periud 1992-202I in the central county, using current (underserved) rates. Table 4.17 shows baseline estimates that incorporate standards below national averages for all categories except hospitals in the years 1996, 2010 , and 2019. Additional staff hires and capital outlay would again depend an level of service desired and available funds.

Highways. For the arid site, highway systems adjacent to the proposed MRS facility are assumed to have overat condition ratings averaging 72 on a scale of 100 (00T 1979). The overalt rating is based on five factors: the condition of the foundation, the condition of the surface, adequacy of drainage, safety features, and capacity to carry the actual existing traffic load. Three adjacent highway systems carry an unknown average daily load. However, a total of 71,000 trucks and cars are prajected to be registered in the central county in 1996, the peak construction year, pius 88,000 in the noncentral county. An additional 2,400 vehicles can be expected to be registered in 1996 in the central and noncentral county as a result of MRS-related population grawth, and this wil? contribute to impact on the highway system. The immediate vicinity of the site would be disrupted during construction by movement of materials to the site plus daily comuting of 435 construction wurkers. If $100 \%$ of the spent fuel and HLW is shipped by truck during operations, 1,943 truck shipments can be expected per year for the loading (1997-2005) and a somewhat lower number (because of consolidation) during unloading (2011-2019) periods. There would also be some impact from daily comuting of 650 workers during loading, 200 workers during storage, and $330-p l u s$ workers during unloading. MRS-related population growth would be expected to add about 880 registered vehicles to the highways of the impact area during the lowest operations year. The impact would then be expected to increase during decomissioning, as 1,500 additional vehicles are registered, commuting increases to 620-plus workers at peak, materials for decomissioning are brought in, and other items are shipped out. Except for general population growth effects, these impacts should be fairly sinilar at all sites, although sites may differ in their capacity to absorb additional traffic. The field drywell cancept woulo have somewhat different impacts on highways near the site than the sealed storage cask concept, thuugh not necessarily higher. On one hand, additional workers would commte to the site during construction (658 instead of 435 ). On the other hand, materials need not be brought in to manufacture casks on site for the drywell facility. The growth in population is higher for the drywell concept, but not as prolonged. From 200 to 500 more vehicles would be registered in the area as a result of MRS-related population growth at the arid reference site for the drywell concept than would be registered under the cask cancept. Neither the impact of additiunal registered vehicles nor the difference from the cask concept is significant. 
For the warm-wet site, highway systems adjacent to the proposed MRS facility are assumed to have overali condition ratings averaging 75 on a scale of 100 . Adjacent highway systems carry an unknuwn average daily load. There are 39,000 cars and trucks registered in the central county in 1996 and 266,000 in the surrounding noncentral county. The traffic load during construction of the MRS facility is estimated to increase by roughiy the same number of vehicles per day as at the arid site; however, vehicle registrations increase less because population impacts are smaller (more existing residents become employed). Vehicle registrations increase by about 500 during peak construction, 250 during the lawest point in operations, and about 500 during the peak of decomissioning. This is not a significant change fron the baseline level. The use of heavy equipment at the MRS site may cause a decline in the overall condition rating, but, in view of the already excellent capacity rating, serious deterioration should not occur.

For the cold-wet site, highway systems adjacent to the proposed MRS facility are assumed to have overall conditicn ratings averaging 69 on a scale of 100 . Adjacent highway systems carry an unknowi average daily load. Only 23,500 cars and trucks are forecasted to be registered in the county in 1996 , but the surrounding noncentral county would have 400,000. The traffic load during construction of the MRS facility is estimated to increase by about the same number of vehicles per day as at the other two sites. The impact of MRS-related population growth on registrations is estimated at 400-plus during peak construction, 170 during the lowest point in operations and 350 during peak decomissioning. These numbers are lower than at the other two sites because the forecast assumes constant numbers of vehicles per capita at historical levels for the region. This number is considerably lower in the cold-wet region, either because vehicles are registered in adjotning counties or because fewer vehicles are owned. Sore variation can also be expected among real sites. The use of heavy equipment may cause a deciline fn the overali condition rating, but, in view of the already excellent capacity rating, serious decline should not occur.

Sewage Systems. Sewage systems are waste water and solid waste management systems. The impacts on these tend to be very site-specific and related to such issues as the capacity of waste treatment facilities, septic tank drain fields, and adequacy of landfills. Little information is avai?able that makes reference site assessments very useful; however, some information is presented below to iliustrate the type of impact that might be expected.

For the arid site, current waste water treatment systems in the central county are considereo adequate for the 109,000 people who live there. Under baseline population projection for 1996 (124,000 people), the existing and planned capacity may not be adequate. When MRS population projection is considerea, the $5 y 5$ tem would nut need major additions above what would otherwise be built to meet baseline growth requirements.

There are three sanitary landfills for solid waste in the reference central courty, all of which are expected to be full around 2010. The additional influx of MRS-related population woulo auvance that date somewhat, but it would appear that the landfills would be adequate during the construction phase 1092 to 1997. During the operation phase, additional sanitary lanofilis might have to be found. The situation at actual sices will have to be assessec on a case-by-case basis.

For the warm-wet site, current capacjty and planned capacity for the central county waste water systems is assumed adequate to serve the 122,000 people who now live there. Under baseline population projection for 1996 (133,000 people), the existing plus planned capacity appears adequate. When laRS population projection is considered, the central county system should not need najor additions, because most population growth is projected for outside the county.

There are three sanitary landfilis for solid waste in the central county, all of which are expected to be full around 2010. The addjtional influx of MRS-related population would advance that date sumewhat but it would appear that the landfills would be adequate during the construction phase 1992 to 1997 . During the operation phase, additional lanofills night have to be found.

For the colo-wet site, current capacity and planned capacity for the waste water systens is assumed adequate to serve the current population of 167,000 people. Under baseline population projection for 19g6 (161,000 people), the existing plus planned capacity appears adequate. When HRS population projection is considered, the system should not need major additions.

There are three sanitary landfills for solid waste in the central county; all are expected to be full around 2010. The additional influx of MRS-related population would advance that date sonewhat but it would appear that the landfills would be adequate during the construction phase 1992 to 1997. During the uperation phase, additional capacity would be required.

Police Protection. For the arid site, the central county is forecasted to need 235 officers in the sheriff's office, state police, and municipal police departments in 1996 fur an average of approximately 1.9 officers per 1,000 people. The national average is 2.6 officers per 1,000 people. If the current. county ratio is maintained, baseline population projections will require 40 additional personnel by 2010 ; MRS activity would require two more than the 40 . Ho additional facilities should be required. The MRS site will provide its own security. No additional officers shuuld be reauired in the noncentral county. 
For the warm-ret site, the central county has 245 officers in the sheriff's office, state police, and municipal police departments for an average of approximately 1.8 officers per 1,000 people. The national average is 2.6 officers per 1,000 people. If the current county ratio is ma intained, baseline population projections will require 30 additional personnel by 2010; MRS activity would not require any more above that. No additional facilities or police vehicles should be required in the central county. ihe noncentral county can expect to need 2 to 3 additional personnel because of MRS impact.

For the cold-wet site, the central cuunty has 310 officers in the sheriff's office, state police, and municipal police departments for an average of approximately 1.9 officers per 1,000 people. The national average is 2.6 officers per 1,000 people. If the current county ratio is maintained, baseline population projections will require 70 additional personnel by 2010 , but MRS activity would not require any likere. Ko additional facilities or vehicles would be required in the central county ds a result of MRS. The nuncentral county may require 3 to 5 aciditional personne?.

If civil disruptions accur at or near the site, additiunal training or help frum the state ray be required from time to tishe to handle such distuptions.

Fire Protection. At all sites, the MRS facility would provide its own fire prutectiun, so this should not be a burden on Tocal government. However, increased population could require additional persunnel or equi prnent.

For the arid site, central county fire protection is providea by all-volunteer county fire departinents and municipal fire departnents. The area has 225 full-time employees in 1996 for an average of 1.8 per 1,000 people; the national average is 5 per 1,000 people. There are 17 fire stations $(0.14$ per 1,000 people) and 60 emergency vehicles of various capabilities $(0.48$ per 1,000 people). The MRS facility would not add significantly to this total. Special equipment and training associated with a radiological site may also be requirea.

For the warm-wet site, central county fire protection is provided by all-voiunteer county fire departments and municipal fire departments. In the baseline forecast for I996, the county fire departments have 270 fuli-time employees for an average of 2.0 per 1,000 people; the national average is 5 per 1,000 people. There are 20 fire stations ( 0.15 per 1,000 people) and 52 fire vehicles of various capabitities (C.39 per 1,000 people). MRS would not significantly affect these requirements, except that special equipnent and training associated with a radiological site may also be required.

For the cold-wet site, central county fire protection is provided by all-volunteer county fire aepartments and municipa fire departments. The area has 285 full-time employees for an average of 1.8 per 1,000 people; the national average is 5 per 1,000 people. There are 21 fire stations (0.13 per 1,000 people) and 52 fire vehicles of variaus capabilities $(0.32$ per 1,000 people). MRS would require no additional personnel and no capital investment for stations and trucks. Special equipment dnd training associated with a radiological site may be required.

Correction facilities. The requirements for correction facilities for the lirs site would depend upon changes in crime rates, poice success rates, conviction rates, and incarceration rates. If all these remain constant, the increase of population associated with MRS would not require additional correction facilities.

Even if these rates change, growth in facilities and personnel to handle population growth in the absence of MRS should be able to absorb the increment in prison population caused by lARS population growth at all but the smallest sites.

Utilities. The utilities considered at the sites are water, electricity and natural gas. In determining the ability of existing utility systems to support estimated population growth, three factors must be considered: existing and pianned resource or capacity estimates, existing and projected consumption rates, and existing and planned delifvery/storage capacities. Tabie 4.18 surmarizes forecasted populationrelated consumption data for baseline and MRS population estimates for peak MRS construction, operation, and decomissioning. The MRS sealed storage cask site itself is expected to use 16,000 gallons of water per day during construction, 210,000 gallons per day during operations, and about 10,000 gallons per day during decomissioning at the arid site (see Table 4.14). The other two sites are expected to use about 14,000 gallons per day during construction, while the cold-wet site should have lower cooling loads and use about 200,000 gallons per day. Electricity and gas use rates are not yet available. Water rights availabitity is a potential concern at the arid site.

For the arid site, wann-wet site, and cold-wet site by 2010 , the baseline population is assumed to not be using tota available resources if the consumption rate remains constant. If no additions are made to the storage/delivery systems, which are assuned to remain usable, then the existing systems will support the demand shown below. Capital investment might be needed for additional system upgrades to surve population added as a result of MRS. 
TABLE 4.18. Population-Related Daily Consumption for Central County Utility Systems During MRS Peak Construction (1995), Operation (2010), and Decommissioning (2020)

\begin{tabular}{|c|c|c|c|c|c|c|c|c|c|}
\hline & & & & Dail & onsump & Rate & & & \\
\hline & & $\left(10^{6}\right.$ & gal $)^{(b)}$ & & $\begin{array}{l}c t r i c t \\
6 \mathrm{kWh})\end{array}$ & & Ga & $10^{3} \mathrm{th}$ & (d) \\
\hline & 1996 & 2010 & 2019 & 1996 & 2010 & 2019 & 1996 & 2010 & 2019 \\
\hline 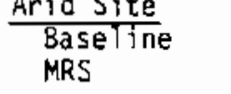 & $\begin{array}{l}370 \\
380\end{array}$ & $\begin{array}{l}430 \\
440\end{array}$ & $\begin{array}{l}460 \\
460\end{array}$ & $\begin{array}{l}6.4 \\
6.5\end{array}$ & $\begin{array}{l}7.5 \\
7.6\end{array}$ & $\begin{array}{l}8.5 \\
8.6\end{array}$ & $\begin{array}{l}950 \\
970\end{array}$ & $\begin{array}{l}1110 \\
1120\end{array}$ & $\begin{array}{l}1250 \\
1270\end{array}$ \\
\hline Warm-Wet Site & & & & & & & & & \\
\hline $\begin{array}{l}\text { Baseline } \\
\text { MRS }\end{array}$ & $\begin{array}{l}260 \\
260\end{array}$ & $\begin{array}{l}300 \\
300\end{array}$ & $\begin{array}{l}340 \\
340\end{array}$ & $\begin{array}{l}4.9 \\
4.9\end{array}$ & $\begin{array}{l}5.6 \\
5.6\end{array}$ & $\begin{array}{l}6.3 \\
6.3\end{array}$ & $\begin{array}{l}430 \\
430\end{array}$ & $\begin{array}{l}480 \\
490\end{array}$ & $\begin{array}{l}540 \\
540\end{array}$ \\
\hline Cold-wet site & & & & & & & & & \\
\hline $\begin{array}{l}\text { Baseline } \\
\text { MRS }\end{array}$ & $\begin{array}{l}250 \\
250\end{array}$ & $\begin{array}{l}270 \\
270\end{array}$ & $\begin{array}{l}290 \\
290\end{array}$ & $\begin{array}{l}4.0 \\
4.0\end{array}$ & $\begin{array}{l}4.2 \\
4.2\end{array}$ & $\begin{array}{l}4.7 \\
4.7\end{array}$ & $\begin{array}{l}1480 \\
1490\end{array}$ & $\begin{array}{l}I 550 \\
1550\end{array}$ & $\begin{array}{l}1710 \\
1720\end{array}$ \\
\hline
\end{tabular}

(a) Assumes no change over time in per capita use.

(b) Based on total water withdrawals per capita for all uses, 1980, including surface water industrial use and irrigation.

(c) Approximately 52 kh per person per day at the arid site, 25 at the cold-wet site, 37 at the warm-wet site.

(d) Approximately 7.7 therms per person per day at the arid site, 9.2 at the cold-wet site, 3.2 at the warm-wet site.

Natural Resources. The extent of investment beyond per capita projections required to protect, conserve, and promote local natural resources will depend upon the level of resource endangerment from the MRS site itself or from the settlement patterns of the immigrating population (such as temporary house trailers). Factors to be taken into consideration include soil and water conservation, irrigation, drainage, and wildlife conservation. For the arid site, wank-wet site, and cold-wet site in 1996, peak MRS operation activities should not affect these areas.

Parks and Recreation. Estimates of additional investment for parks and recreation beyond per capita projections must include foregone recreational opportunities. Within 10 miles of the arid site, recreation consists mainly of bird hunting on Bureau-of-Land-Management property, recreational-vehicle driving or trail biking, and some target shooting or rabbit hunting. There are very few sightseeing attractions, but there are a variety of recreational facilities in the area. No major impact to area outdoor recreation will occur as a result of MRS construction, operation, or decommissioning. The same should be true for nost indoor recreation, although some facilities may become slightly more crowded.

For the warm-wet site, outdoor recreation consists of small animal, bird, and deer hunting, fishing on natural and constructed bodies of water (some stocked by state departments of fish and game), recreational vehicle oriving, boating, swimming, water skiing, picnicking, and hiking. There are few specific sightseeing attractions in the lmmediate vicinity. Much of the recreational hunting takes place on private property, while other activities are predominantly done at state, county, city, and federal recreation areas.

For the cold-wet site, outdoor recreation opportunities are very similar to those at the warm-wet site. There is less deer hunting, more bird hunting, and winter outdoor recreation includes ice fishing, skating, and some cross-country skiing.

In the central county of the arid site, wanm-wet site, and cold-wet site, the standard of service for recreation (employees and acres per capita) arops sTightiy as a result of the HRS-reiated increase in county population. However, this increase does not require an increase in either the number of acres or employees in the county and city parks systems. Growth in the systems required to support baseline population growth should be adequate to handle MRS impacts.

\subsubsection{Special Nuclear-Related Socioeconomic Effects}

Additional socioeconomic impacts may occur in the case of an MRS facility because of the special nuclear nature of the facility. While the facility has been designed to operate safely, the local and state govemments and Indian tribes located near the facility may decide that they must conduct liaison, independent monitoring, inspection, emergency response pianning and other activities related to the shipment or storage of spent fuel and HLW at the MRS site. The costs of conducting these activities would be additional socioeconomic impacts on the participating governments or tribes. Estimates have been made of sume of the initial planning costs, but other nuclear-related costs will be very site specific, so analysis of these costs has not been conducted for the reference sites. 
Another source of special nuclear-related socioeconomic impact is that consumers may possibiy avoid agricultural or fishery products produced near the facility or avoid recreationat activity in the area. This may be especially true if an accident were to occur at the site. Public response has been studied for reactor accidents (Pennsylvania Department of Comerce 1979; Nelson 1981; Gamble and Downing 198I; Pennsylvania Governor's Office 1979; Pennsylvania Department of Agriculture 1980). Accidents of the type discussed in this literature could not occur at a storage facility. (See Section 4.1.3 for a list of potential accidents considered for the MRS facility.) However, public response could be similar. If this response were to occur, it may adversely affect property values and existing agricultural, fishery, and recreationa? businesses located in the area. Because of the difficulty of predicting the degree of consumer response and specific resources affected, these impacts were not analyzed quantitatively for the reference sites.

\section{6 .5 Surnmary}

In summary, while each of the regions may endure some adverse impact on its population, income, fiscal balance, and community services, the socioeconomic impacts of MRS are not expected to be large. In many cases, depenoing on the aspect of socioeconomic impact examined, there is likely to be no adverse impact at a 11. Except for the construction period and early part of the operations period, the sealed storage cask and field drywell concepts are very similar; so are the socioeconomic impacts. Sightly higher impacts are expecteo ouring construction of a drywell facility with perhaps slightiy higher overall impacts of a cask facility because of concurrent cask butlding.

The size and distribution of the impacts vary significantly among the reference sites considered in this analysis. Because of its smaller population base, the arid site tends to experience relatively lower employment gains (because of lower secondary employment) and fairty high population gains because the existing labor force and commnity must grow more to accommodate the MRS facility. The warm-wet site is likely to have low labor force participation and can accomodate the project with relatively 5malt population gain. The cold-wet site experiences a fairly large population response, probably because of low costs of migration to this site and the presence of many available workers just outside the commuting zone. The warm-wet site shows mostly lower expenditure requirements, partly because of low service standards and low wage rates for local government employees. The cold-wet site shows relatively high public sector costs because the opposite conditions prevail. The arid site has Tow service standards, but relatively high wage rates, so the fiscal impacts are intermediate in size.

\subsection{RESOURCE REQUIREMENTS AND COST IMPACTS}

The resource requirement and cost estimates for construction, operation, decomissioning, and transportation needs for an MRS facility are presented in this section. The resource requirements vary mainly by concept and little by site; climate is considered in some design parameters (e.g., design of foundations includes frost line). Costs may vary by site because of varying costs for transportation and because of regional differences in the costs of specific materials. Resource requirements for the sealed storage cask concept are given in Table 4.19 and for the field drywell concept are given in Table 4.20 .

The costs associated with an MRS facility include the direct labor and materials costs for constructing, operating, and decomissioning the facility and the transportation costs for transporting nuclear waste from its generation point to the MRS facility and for transporting the waste from the MRS facility to a permanent waste repository. Other costs include the possible payments to local governments, state governments, and Indian tribes to mitigate the fiscal impacts that the MRS facility may have on their operations.

Costs for all site/concept combinations have been converted to present value terms using an MRS program-mandated $2 \%$ real discount rate so that estinated costs can be compared on a consistent basis. All present value estimates are representative of the present value in 1985 . All cost estimates account for differences in costs resulting from the specific characteristics of the six site/concept combinations. Estimates of the present value in 1985 of all labor, materials, and total costs for construction, operation, and decomissioning are in Table 4.21 for a sealed storage cask facility and in Table 4.22 for a field drywell facility.

\subsubsection{Construction Activities}

These cost estimates were calculated using basic data from an MRS project data base that has detailed estimates of the annual labor and materiais costs associated with construction of a sealed storage cask facility. For these estimates, construction is assumed to begin in 1992 and is estimated to require five years. The annual payments were first discounted to present value in 1992 when construction is assumed to have begun and then further discounted to present value in 1985.

The present value of the construction expenditures for a drywell facility at the arid site is the highest among the six site/concept combinations. The reasons for this relative cost position are primarily that the drywells would all be constructed at the beginning of the project, which requires a large investment, and that labor is especially costly at the arid site. 
IABLE 4.19. Resource Requirements for a 15,000 MTU MRS Facility, Sealed Storage Cask

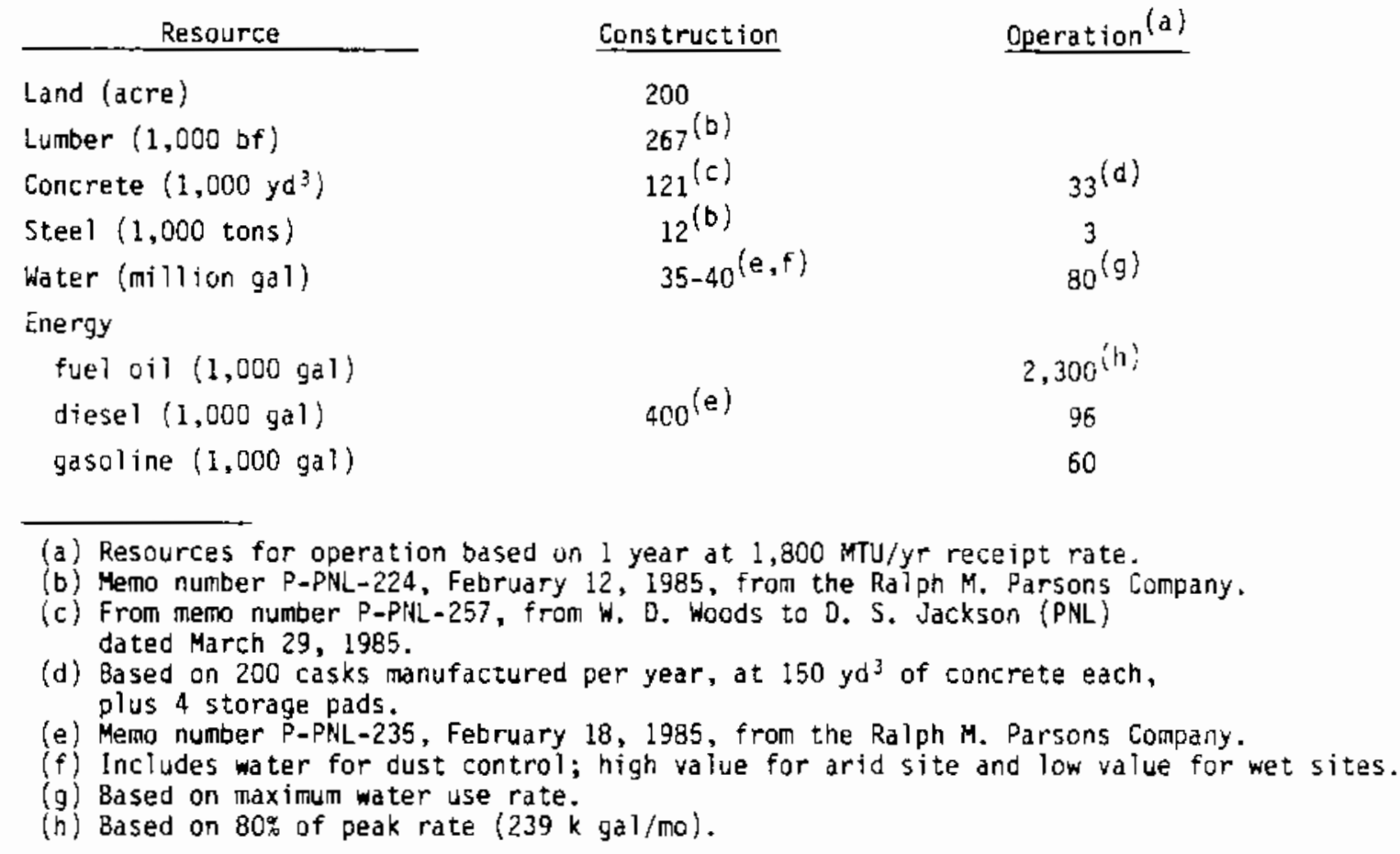

TABLE 4.20. Resource Requirements for a 15,000 MTU MRS Facility, Field DrywelT

\begin{tabular}{|c|c|c|}
\hline Resource & Construction & Operation $\{a\}$ \\
\hline Land (acre) & $250-350$ & \\
\hline Lumber $(1,000$ bf $)$ & $267^{(b)}$ & \\
\hline Concrete $\left(1,000 \mathrm{yd}^{3}\right)$ & $98^{(c)}$ & $2-4$ \\
\hline Stee $(1,000$ tons $)$ & $12^{(b)}$ & 4 \\
\hline Water (million gal) & $13-40^{(e, f)}$ & $\left.70^{\{9}\right\rangle$ \\
\hline \multicolumn{3}{|l|}{ Energy } \\
\hline fuel oil $(1,000 \mathrm{gal})$ & & $2,300^{(h)}$ \\
\hline diesel $(1,000$ gal $)$ & $400^{(e)}$ & 96 \\
\hline gasoline $(1,000$ gal $)$ & & 60 \\
\hline
\end{tabular}

(a) Resources for operation based on 1 year at 1,800 MTU/yr receipt rate.

(b) Memo number P-PNL-224, February 12, 1985, from the Raiph M. Parsons Company.

(c) From memo number P-PNL-257, from $W$. 0 . Woods to 0 . S. Jackson (PNL) dated March $29,1985$.

(d) For collars around drywells.

(e) Memo number P-PNL-235, February 18, 1985, from the Ralph M. Parsons Company.

(f) Includes water for dust control; high value for arid site and low value for wet sites.

(g) Based on maximum water use rate.

(h) Based on $80^{\circ}$ of peak rate $(239 \mathrm{k}$ gal/mo). 
TABLE 4.21. Present Vaive Cost Estimates for Construction, Operałign, and Decormissioning, Sealed Storage Cask (milition 1985\$)

\begin{tabular}{|c|c|c|c|c|c|c|c|c|}
\hline \multirow[t]{2}{*}{ Site } & \multicolumn{3}{|c|}{ Construction $(b)$} & \multicolumn{3}{|c|}{ Operations and Maintenance } & \multirow{2}{*}{$\frac{\text { Decormissioning }}{\text { Total }}$} & \multirow[t]{2}{*}{$\begin{array}{c}\text { Facility } \\
\text { Total } \\
\text { (rounded) } \\
\end{array}$} \\
\hline & Material & Labor & Total & ${\text { Capitai }^{(d)}}^{(d)}$ & Operations & Total & & \\
\hline Arid & $\$ 266$ & $\$ 120$ & $\$ 386$ & $\$ 294$ & $\$ 421$ & $\$ 715$ & $\$ 16$ & $\$ 1,100$ \\
\hline Warm Wet & 260 & 93 & 353 & 255 & 365 & 620 & 14 & 1,000 \\
\hline Cold wet & 264 & 114 & 378 & 286 & 409 & 695 & 16 & 1,100 \\
\hline
\end{tabular}

(a) Costs were adjusted for the three sites using geographic adjustment factors supplied by the architectengineer, the Ralph M. Parsons Company, in "Monitored Retrievable Storage (MRS) Facility, Conceptual Design Report, Cost Estimate Summaries (Draft)," prepared for the DOE in January 1985.

(b) Costs assume a construction period of 5+ years (1992-1997). All costs were discounted to mid-1985 at a $2 \%$ discount rate. They include contractor overhead and profit, contingency, and prime contractor profit and management fee.

(c) Includes decontamination costs incurred during outshipment of spent fuel and waste (2011-2019), as well as decomissioning (2018-2021). These costs were discounted to mid-1985 in the same manner as in footnote (b).

(d) Includes costs for capttal items (e.g., canisters, additional casks) that appear in the operations and maintenance phase (1997-2019). These costs were discounted to mid-1985 in the same manner as in footnote $(b)$.

TABLE 4.22. Present Value Cost Estimates for Construction, Operation, and Decomissioning, Fieid Drywell (million 1985s)

\begin{tabular}{|c|c|c|c|c|c|c|c|c|}
\hline \multirow[t]{2}{*}{ Site } & \multicolumn{3}{|c|}{ Construction $(b)$} & \multicolumn{3}{|c|}{ Operations and Maintenance } & \multirow{2}{*}{$\frac{\text { Decomissioning }}{\text { TotaI }}$} & \multirow[t]{2}{*}{$\begin{array}{c}\text { Facilitity } \\
\text { Total } \\
\text { (rounded) }\end{array}$} \\
\hline & Material & Labor & Total & Capital $^{(\mathrm{d})}$ & Operations & Total & & \\
\hline Arid & $\$ 342$ & $\$ 162$ & $\$ 503$ & $\$ 143$ & $\$ 439$ & $\$ 582$ & $\$ 18$ & 51,100 \\
\hline Harm Wet & 333 & 127 & 460 & 124 & 381 & 505 & 16 & 1,000 \\
\hline Cold wet & 337 & 154 & 491 & 139 & 426 & 565 & 17 & $1, \pm 00$ \\
\hline
\end{tabular}

(a) Costs were adjusted for the three sites using geographic adjustment factors supplied by the architectengineer, the Ralph M. Parsons Company, in Monitored Retrievable Storage (MRS) Facility, Conceptual Design Report, Cost Estimate Summaries (Draft)," prepared for the DOE in vanuary 1985.

(b) Costs assume a construction period of 5+ years (1992-1997). All costs were discounted to nud-1985 at a $2 \%$ discount rate. They include contractor overhead and profit, contingency, and prime contractor profit and management fee.

(c) Includes decontamination costs incurred during outshipment of spent fuel and waste (2011-2019), as well as decomissioning (2018-2021). These costs were discounted to mid-1985 in the same manner as in footrote (b).

(d) Includes costs for capital itens (e.g., canisters, additional drywells) that appear in the operations and maintenance phase (1997-2019). These costs were discounted to mid-1985 in the same manner as in footnote $(b)$.

\subsubsection{Operation Activities}

The estimate of the 1985 present value of the operating costs (Tables 4.21 and 4.22 ) for an assumed time period of 1997 to 2019 was calculated by converting data on the total annual costs of MRS facility operation to present value in 1992 using a discount rate of $2 \%$. The same discount rate was then used to convert present value in 1992 to present value in 1985.

The estimated operaring costs of a sealed storage cask at the arid site are the highest anong the six site/concept combinations. This is again because unit costs, materials, and labor are higher at the arid site and because the casks themselves require a substantial investment. 


\subsubsection{Decormissioning Activities}

The estimated present value in 1985 of the decomissioning costs after a 25 -year operating 1 ife is about $\$ 14$ to $\$ 18$ million. This estimate was calculated by converting the decomissioning cost estimate from the MRS data base to present value in 1985 using a $2 \%$ discount rate. Note that part of the reason the present vaiue of decomaissioning costs is relatively small is because costs witl be incurred so far in the future.

\subsubsection{Transportation Activities}

The costs of transporting radioactive waste to any type of IRS facility will be highly variable depending upon the distance the waste is shipped, the size of shipment, the type of waste shipped, the moce of transportation, and other factors. Transportation costs for shipping radioactive waste have been estimateo in several studies (e.g., Daling and Engel 1983), and these studies illustrate that a large amount of detailed information must be considered to accurately portray transportation costs for radioactive wastes. In addition, specific potential locations for MRS facilities must be identifiea before cransportaticn costs can be compared among the site/concept combinations. Because transportation costs depend upon su many different factors, "representative" costs are not attempted here. Iransportation cost estimates will be incor. porated in future analyses of the resource requirements of MRS facilities when the information necessary to develop such estimates is available. Although advanced analytical tools are available for transportation analyses (Wilmot et al. 1983; Neuhauser et al. 1984), the reference-site data used in this report are not specific enough for a meaningful analysis.

\subsubsection{Fiscal Costs}

Resource requirements for fiscal activities are resources that may be required to mitigate the socioeconomic impacts (described in Section 4.6) on local governments, state governments, and indian tribes. In this section, the estimated resources required for fiscal activities are described. The net annual impacts on the fiscai condition of local and state governments derived in Section 4.6 provide the basis for the resource requirement estimates developed here.

Local Government Costs. The present value in 1985 of the resources required to mitigate the MRSrelated population-related expenditure impacts on local governments is presented in Table 4.23. This estimate was derived by converting the annual impacts on local governments to present-value terms using an assumed discount rate of $2 \%$ and assumed time periods of years 1992-1997 for construction, years 1997-2019 for operation, and years 2018-2021 for decomaissioning. All annual costs were first converted to present value in the year a phase (construction, operation, or decomaissioning) of the MRS facility is assumed to occur and then converted to present value in 1985. Population-related expenditures are chosen in this table as the measure of local government impact because it is not clear to what extent the additional resource requirements may be met from the local government's own sources and to what extent frum federal sources. The Nuclear Haste Policy Act says that the amount will be negotiated between DOE and the governments involved. Table 4.23 does not include an estimate of the costs of planning, consultation, and special nuclear-related activities of local government because estimates of these items are not yet available. Higher population immigration and higher per capita expenditures cause the resources required to niitigate the impacts on local governments of a field drywell facility at the cold-wet. site to be the highest among all site/concept combinations.

State Government Custs. The present value in 1985 of the estimated resuurces required to alitigate the MRS population-related impacts on state government expenditures is also presented in Table 4.23. This estimate was calculated by converting estimates of the annual impacts on state governments (described in Section 4.6) to present value using the method described above for local government casts.

Indian Tribe Fiscal Resource Requirements. There appears to be little ar no possibility of placing an ARS facility on Indian tribal lands and no transportation routes have been chosen. Thus, no estimates of the resaurce requirements for alitigating impacts on Indian tribes were developed. No cost data were available for special nuclear-related costs to the tribes from a nearby MRS facjlity.

\subsubsection{Sunmary}

The materials required for building and operating an MRS facility are commonly avaflable, so no irretrievable comaitment af scarce resources is necessary.

Socioeconomic impacts are small at the reference sites examined. Total employment impacts range from 400 to 2,100, and population impacts range from 800 to 4,100 , depending an the concept, site, and stage of operation. Most maderate-sized regianal populations could absoro these impacts without serious adverse effects. Based on the reference sites, annual public service expenditures of state and local governments could increase by up to $\$ 23$ million to take care of the additional population; however, at least part of the increase would be offset by increased revenues from various taxes, fees, and intergovernmental payments. As a result, the net impact on state revenues could be either posicive or negative. 
TABLE 4.23. Estimated Present Value of Resource Requirements for State and Local Governments Related to MRS Impacts

Estimated Present value Impacts (milition 1985\$)(a)

Site/Concept and Fiscal Component Construction Operation Decominissioning Total Resources

\section{Seated Storage Cask}

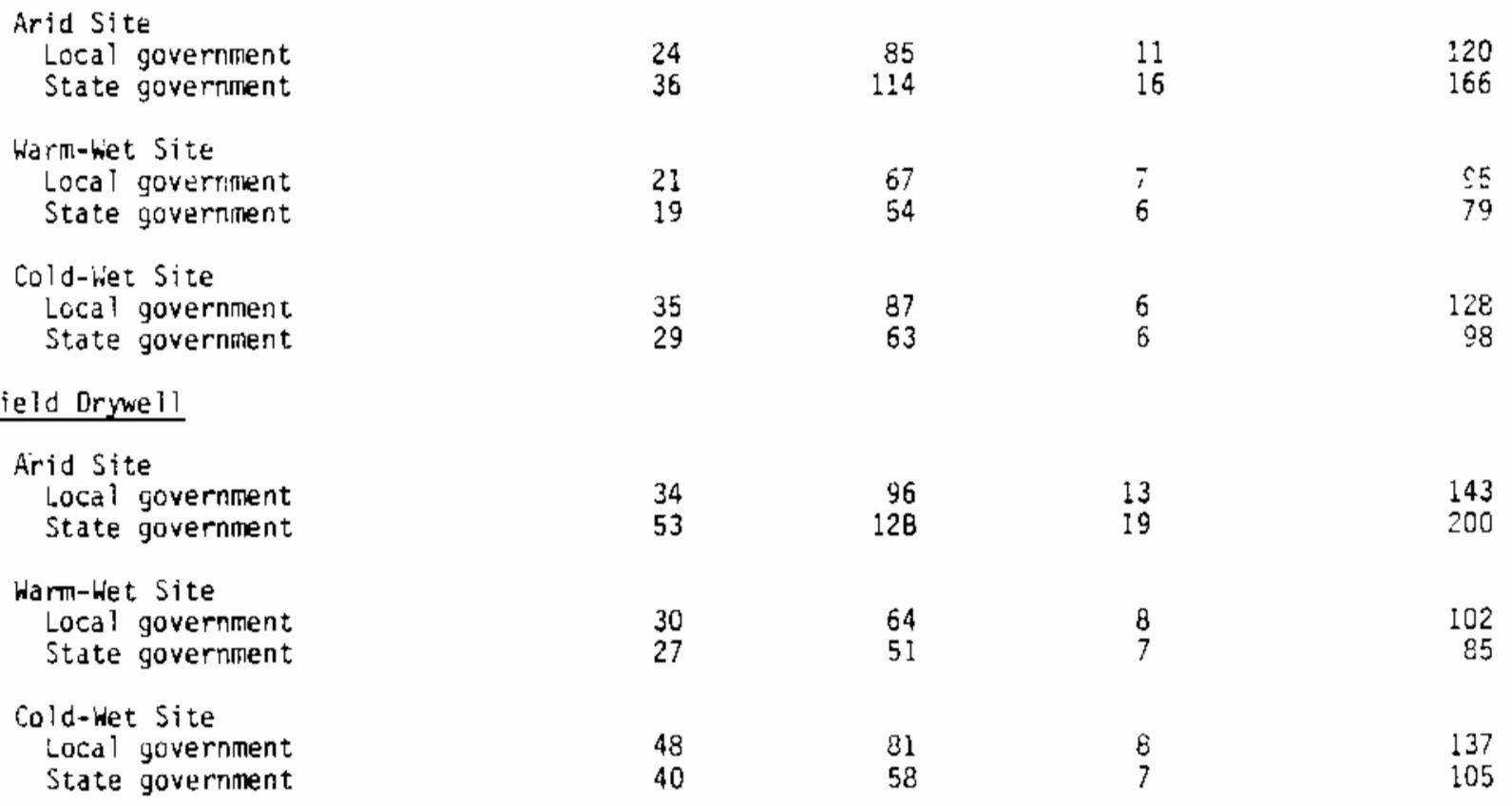

(a) Single year annud impacts for local and state governments are shown in Section 4.6 for key years. 


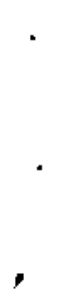

.

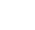




\subsection{COMPARISON OF IMPACTS}

This chapter sumarizes environmental impacts of an MRS facility and shows how the impacts may vary among the six site/concept combinations. The impacts and their variations are small and in some cases negligible.

\section{I RAOIOLOGICAL IMPACTS}

The radiological impacts among the three site types are compared here for operation and transportation activities related to the MRS. Construction and decomissioning activities are not included because no release of consequence could be identified in performance of the radiological evaluation. (See Section 4.1 and Appendix $B$ for details of radiological impacts.)

Table 5.1 presents a sumary of radiological impacts for nomal design basis, operatiun accidents and transportation. The individual doses presented in this table are below the regulatory itinits of 0.025 rem for normal operations and transportation and 5 rem for design bas is accidents (10 CFR 72). The population doses are well below the dose received by the indicated population group from background radiation (see section 4.1). The following sections discuss the effect of parameter vatue variations on the impacts presented.

IABLE 5.1. Summary of Radiological Impacts from an MRS Facility

\begin{tabular}{|c|c|c|c|c|c|c|}
\hline \multirow[b]{2}{*}{ Activity/Population Group } & \multicolumn{3}{|c|}{ Sealed Storage Cask } & \multicolumn{3}{|c|}{ Field Drywell } \\
\hline & Arid Site & $\begin{array}{l}\text { Warm-Wet } \\
\text { Site }\end{array}$ & $\begin{array}{c}\text { Cold-wet } \\
\text { Site } \\
\end{array}$ & Arid Site & $\begin{array}{l}\text { Warm-Het } \\
\text { Site } \\
\end{array}$ & $\begin{array}{l}\text { Cold-wet } \\
\text { Site }\end{array}$ \\
\hline \multicolumn{7}{|l|}{ Norma? Operations } \\
\hline $\begin{array}{l}\text { Background (person-ren) } \\
\text { Population (person-rem) } \\
\text { Maxinum Individual (ren) }\end{array}$ & $\begin{aligned} 20,000 \\
0.1 \\
<0.001\end{aligned}$ & $\begin{aligned} & 60,000 \\
& 0.1 \\
&<0.001\end{aligned}$ & $\begin{array}{c}160,000 \\
0.2 \\
<0.001\end{array}$ & $\begin{aligned} 20,000 \\
0.1 \\
<0.001\end{aligned}$ & $\begin{array}{l}60,000 \\
0.1 \\
<0.001\end{array}$ & $\begin{array}{r}160,000 \\
0.2 \\
<0.001\end{array}$ \\
\hline \multicolumn{7}{|l|}{ Design Basis Accident ${ }^{(a)}$} \\
\hline $\begin{array}{l}\text { Background (person-rem) } \\
\text { Population (person-rent) } \\
\text { Maximum Indivioual (rem) }\end{array}$ & $\begin{array}{l}20,000 \\
6 \\
0.042\end{array}$ & $\begin{array}{l}60,000 \\
20 \\
0.010\end{array}$ & $\begin{array}{r}160,000 \\
10 \\
0.008\end{array}$ & $\begin{array}{l}20,000 \\
6 \\
0.019\end{array}$ & $\begin{array}{l}60,000 \\
20 \\
0.006\end{array}$ & $\begin{array}{l}160,000 \\
20 \\
0.005\end{array}$ \\
\hline \multicolumn{7}{|l|}{ Transportation $(b)$} \\
\hline $\begin{array}{l}\text { Background (person-rem) } \\
\text { Population (person-rem) } \\
\text { Maximum Individual (rem) }\end{array}$ & $\begin{array}{l}200,000 \\
2,000 \\
0.011\end{array}$ & $\begin{array}{r}200,000 \\
2,000 \\
0.010\end{array}$ & $\begin{array}{r}200,000 \\
2,000 \\
0.010\end{array}$ & $\begin{array}{l}200,000 \\
2,000 \\
0.011\end{array}$ & $\begin{array}{r}200,000 \\
2,000 \\
0.010\end{array}$ & $\begin{array}{r}2 C 0,000 \\
2,000 \\
0.010\end{array}$ \\
\hline
\end{tabular}

(a) The worst design basis accident for the sealed storage cask concept is a diesel fuel fire in the rail yard. For the field drywell concept, the worst design basis accident is a canister shearing incident. (See Section 4.1 .3 for a description of these and other accidents.)

(b) The transportation analysis includes impacts for spent fuel and waste transport to the MRS and from the MRS to a distant repository (at 4,000 km) as a bounding analysis. Shipment rates were assuned to be the same for both phases; reduction in the number of shipments from the MRS caused by fuel consolidation was not considered.

\subsubsection{Qperation Activities}

Reference-site parameters used include the meteorological data base, population distribution, location of the nearest resident and terrain characteristics. The meteorological data base is used to estimate downind dispersion of airborne effluents. (The radiation dose to an individual is proportional to the dispersion factur for a given site). The dispersion factors for the three reference sites analyzed give a representative expected range (see Table $8.7,8.8$, and B.9). The location of the nearest resident (maximum individual) is critical to the calculation of individual dose because the atmospheric dispersion factor is very dependent on downind distance. The analysis presented assumes the individual to be located in the 3 to 5-kilometer interval. The dispersion factors (Table B.8) could change by an order of magnitude: either higher if the individual were to be located nearer, or lower if the individual were farther away.

The population dose for a given site is dependent on the population distribution and density near the site (usually a 50-mile (80-km) radius). As the population increases, the population exposure increases. A150, where the population lives nearer the site, the populatiun exposure will increase.

The dispersion calculations for the three reference sites are based on flat terrain. The largest potential effect of terrain elevation vartation would be to minimize the benefit of a stack. However, the 
present analysis was performed assuming ground-level releases. Therefore, terrain effects would not be expected to change the calculated impacts appreciably. The dispersion factors calculated are considered to give a representative range of values irrespective of terrain features. If specific candidate sites are identified, site-specific terrain features should then be considered.

\subsubsection{Operating Accidents}

The effect of site-specific parameters describej for nomal operations also applies to accident evaluations. However, for accidencs the location of the maximally exposed indiviaual is assumed to be at the site boundary. Because the location of the maximum individual is fixed, the dispersion factors for this calculation are not expected to vary significantly beyond the range in Table 8.12.

\subsubsection{Transportation Activities}

The primary depenoence uf transportation dose impacts is on the distance traveled and the population density of the transport route. The location uf the MRS site relative to shipment points and relative to the geologic repository is a primary consideration in the analysis of transport inpacts. Changes in the distances will have proportionate changes in impacts. Change in transport routes to include mure transport through higher-populaticn-density areas witl result in higher public pepulation exposures fur both numa? and postulated accident conditions. The route population density representations for the three reference sites give a reasonable range of Tikely conditions for the United States (see Table B.4).

\subsection{AIR QUALITY IMPACTS}

The greatest air quality impact, as measured by a percentage of the National Himbient Air Quality Standards ( 40 CFR 50 ), is dust concentration during construction. However, even at the driest (dustiest) site, the estimated annual average offsite dust concentration $\left(\mathrm{PM}_{10}\right)$, at a location $3-5 \mathrm{~km}$ from the plant. site boundary, is less than that allowed by the ambient standard. Temporary construction emissions are usually not required to meet the anbient air quality standards.

The operation of an MRS facility would have a negijgible effect on air quality. Cumbustion of fuel $0 i l$ is the major source of emissions from an operating facjlity; average annual cuncentratiur uf combustion products does not exceed one percent of that allowed in the ambient standard (40 CFR 50). 0ifferences in atmospheric dispersion characteristics at the three reference sites nake no appreciable difference in the environmental impact of the facility.

Airborne emissions from decomissioning of an MRS facility are expected to be substantially less than those from either construction or operation. No significant air quality inpacts are expected, regardless of local neteorology.

\subsection{WATER QUALITY IMPACTS}

Availability of water, yround water for nomal operations and surface water for backup, is an important consideration in site selection. Insufficient water or the inability to obtain water use permits may preclude siting an MRS facility in some locations. The pumping rate required for uperation of an MRS facility is reascnable for one well in most locations. Water use should have a negligible effect on the water table for nearby residents.

The operation of di MRS facility poses no significant risks to the water supply. Conventional biological treatment is useo on sanitary waste water. The effluent from multi-stage treatment of process waste water is high quality and should have no adverse effect on surface water quality. water.

The MRS facilicy should have no significant effect on the quality of either surface water or ground

\subsection{LAND USE IMPACTS}

Land requirements for an MRS are about 200 acres for the sealed storage cask concept and up to 350 acres for the field drywell concept.

For construction, operation, and decommissioning, the land use impacts should be comparable for all site/concept combinations. For a sumary of land use impacts, see section 4.4.4. 


\subsection{BIOLOGICAL IMPACTS}

For construction of an MRS facility at any of the three reference sites, the disposal of the excavated soil and associated vegetation will destroy existing habitat for small burrowing mamals, birds, reptiles, insects, etc., although the disposed overburden could becone similar habitat after it has stabilized and revegetated. Impacts will probably be greater in the wanl-wet and cold-wet sites because of the greater loss of vegetation and generaliy higher populations of organisms. Restoration of vegetation (except for trees) on the disposed soil wili probably be more rapid in the warm-wet site and slowest in the arid site, oue to different precipitation levels, temperatures, etc.

For operation, decomissioning, and transportation, biological impacts should be comparable for all site/concept combinations. See Section 4.5 .5 for a sumary of biological inpacts.

\subsection{SOCIOECONOMIC IMPACTS}

This section describes how site characteristics affect the level of econumic, demographic, corranity service and fiscal impacts of an MRS. In general, socioeconomic impacts depeno on site-specific information:

- the size and character of the economy

- the size and demography of the community

- the capacity of the community's existing housing, utilities, and pubilic services

- the availability of labor of the necessary training

- the role an economy plays in relation to the surrounding region.

Large communities and large regional economies, because they provide a broad range of goods and services, would tend to attract the population ano economic growth assuciated with an MRS. In aduition, larger multiplier effects would usually uccur, causing larger absolute impacts on the economy. However, these absolute impacts would still constitute a smaller percentage of a large economy's baseline activity. Similarly, a large population would be more likely to absorb MRS impacts without significant gruwth-relateo disruption, because the percentage growth requirements for housing, schoois, utilities and medical services are smaller for large communities. Conversely, sparsely populated rural areds would more likely have to increase their public service base ta accommodate MRS-related growth.

\subsubsection{Employkent and Income}

About 400 to 700 workers would be employed during each year of construction. An average of 400 workers would be employed during each of the 25 years of operation. The impacts uf the PRS facility on employnent and income are related to the size of the economy into which the MRS is intruduced. This can be seen by examining Table 5.2 and comparing the relative inpacts at the three reference sites for the sealed storage cask concept. During all three stages of the project, the construction of the MRS faci $i$ ity has a greater absolute employment and income impact at the warm-wet site than at the smaller (arid) site. However, this is not the case for the cold-wet site because of its supporting economic role in a larger economy. The only consistent finding is that the absolute impact tends to grow less tinan proportionately as reyion size increases, so that, in percentage terms, the larger the region, the less important the impact. In generai, it is not possible to say whether the impacts would be different or the same at other sites. However, the impacts are small ano not very different over a wide range of sizes for the baseline econories i 1996 enployment from 109,000 to 768,000 ) within the study area, even when chosen in three different regions of the country.

Table 5.3 compares MRS impacts on regional employment and income for the field dryweli concept. While the impacts would be up to 50 s larger in buth absolute and percentage terms compared to those of the sealed storage cask (especially during construction), they are still very small in relation to the reference site economies examined in this environmental report.

In both Tables 5.2 and 5.3 , income appears to be affected less than employment when compared with corresponding baseline values. The reason may be that many of the people living in the wanm-wet reference site are employed outside the area. Thus, while their incomes appear in the baseline totals because incone is reported by place of residence, their employment does not appear in the region totals because enployment. is typically reported on a place-of-work basis. Another factor causing differences in the percentage increases in incume and employment is that some of the extra incone is earned by people already employed in each region. Their additional services are not reflected in the change in employment. 
TABLE 5.2. Relationship of MRS Regional Employment and Income Impacts to Baseline Conditions, Sealed Storage Cask

\begin{tabular}{|c|c|c|c|c|c|c|}
\hline \multirow[b]{2}{*}{ Year and Site } & \multicolumn{3}{|c|}{ Enployment } & \multicolumn{3}{|c|}{ Income } \\
\hline & $\begin{array}{r}\text { Baseline } \\
\text { (persons) }\end{array}$ & $\begin{array}{c}\text { MRS } \\
\text { Impact } \\
\text { (persons) }\end{array}$ & $\begin{array}{c}\text { MRS Impact } \\
\text { ( } \% \text { of } \\
\text { Base line) } \\
\end{array}$ & $\begin{array}{c}\text { Baseline } \\
\text { (million } \\
\text { 1985\$) } \\
\end{array}$ & $\begin{array}{c}\text { MRE Impact } \\
(\text { mi } 111 \text { ion } \\
1985 \$) \\
\end{array}$ & $\begin{array}{c}\text { MRS limpact } \\
\text { ( } \% \text { of } \\
\text { Basel ine) }\end{array}$ \\
\hline \multicolumn{7}{|l|}{1996} \\
\hline Arid & 109,000 & 1,100 & 1.0 & 3,700 & 34 & 0.9 \\
\hline Warm wet & 172,000 & 1,500 & 0.9 & 7,000 & 44 & 0.6 \\
\hline Coid wet & 768,000 & 1,150 & 0.2 & 25,200 & 37 & 0.1 \\
\hline \multicolumn{7}{|l|}{2010} \\
\hline Arid & 146,000 & 500 & 0.3 & 5,700 & 18 & 0.3 \\
\hline Warm wet & 158,000 & 550 & 0.3 & 8,500 & 20 & 0.2 \\
\hline Cold wet & $1,033,000$ & 400 & $<0.1$ & 30,000 & 12 & $<0.1$ \\
\hline \multicolumn{7}{|l|}{2019} \\
\hline Arid & 184,000 & 1,100 & 0.6 & 7,700 & 42 & 0.5 \\
\hline Warm wet & 160,000 & 1,150 & 0.7 & 10,200 & 48 & 0.5 \\
\hline Cold wet & $1,341,000$ & 950 & 0.1 & 37,500 & 25 & 0.1 \\
\hline
\end{tabular}

TABLE 5.3. Relationship of MRS Regional Employment and Income Impacts to Baseline Conditions, Field Dryweli

\begin{tabular}{|c|c|c|c|c|c|c|}
\hline \multirow[b]{2}{*}{ Year and site } & \multicolumn{3}{|c|}{ Enployment } & \multicolumn{3}{|c|}{ incume } \\
\hline & $\begin{array}{r}\text { Baseline } \\
\text { (persons) }\end{array}$ & $\begin{array}{c}\text { MRS } \\
\text { Impact } \\
\text { (persons) }\end{array}$ & $\begin{array}{c}\text { MRS Impact } \\
\left(\begin{array}{c}* \\
0\end{array} \text { of }\right. \\
\text { Basel ine) } \\
\end{array}$ & $\begin{array}{c}\text { Baseline } \\
\text { (million } \\
1985 \$) \\
\end{array}$ & $\begin{array}{c}\text { MRS Impact } \\
(\text { titi } 11 \text { ion } \\
1985 \$) \\
\end{array}$ & $\begin{array}{c}\text { HRS Impact } \\
\left(\begin{array}{c}* \\
0\end{array} \text { of }\right. \\
\text { Baseline) } \\
\end{array}$ \\
\hline \multicolumn{7}{|l|}{1996} \\
\hline Arid & 109,000 & 1,600 & 1.5 & 3,700 & 49 & 1.3 \\
\hline Want wet & 172,000 & 2,100 & 1.2 & 7,000 & 62 & 0.1 \\
\hline Cold wet & 768,000 & 1,650 & 0.2 & 25,200 & 52 & 0.2 \\
\hline \multicolumn{7}{|l|}{2010} \\
\hline Aria & 146,000 & 550 & 0.4 & 5,700 & 20 & 0.4 \\
\hline Wam wet & 158,000 & 600 & 0.4 & 8,500 & 22 & 0.3 \\
\hline Cold wet & $1,033,000$ & 450 & $<0.1$ & 30,000 & 12 & $<0.1$ \\
\hline \multicolumn{7}{|l|}{2019} \\
\hline Arid & 184,000 & 1,150 & 0.6 & 7,700 & 46 & 1.0 \\
\hline Harn wet & 160,000 & 1,250 & 0.8 & 10,200 & 52 & 0.5 \\
\hline Cold wet & $1,341,000$ & 1,000 & 0.1 & 37,500 & 28 & 0.1 \\
\hline
\end{tabular}

\subsubsection{Population and Housing}

The impacts of the MRS facility on population and housing are expected to be small. (a) The results vary sumewhat between sites, but again the only consistent results are that the impacts are smal] and proportionately less important in large regions. The results are shown in Table 5.4 in order of increasing population size. In the MRS impact regions as a whole, population and housing demand impacts are more significant for small regions than for targe ones, even though no impact is larger than 1.3\% of baseline. In the central counties, this ranking is made more complex by the result that the arid region's population growth is concentrated near the MRS facility, while it is dispersed because of the more decentralized residence pattern in the other two regions. This variation occurs among real sites as well and could inftuence the level of socioeconomic impact experienced. In ro case, however, is the central area population or housing demand inpact large enough in relation to the baseline to be cunsidered disruptive unless it were concentrated on a few small commuities. In general, one would expect the impacts of a sealed storage cask MRS at other sites to fall into the range shown in Table 5.4--between 1,700 and 2,950 new people within the 50-mile $(80-\mathrm{km})$ radius from the site auring construction, somewhat less during most of

(a) 0ther commity services and inflation-adjusted public revenues and expenditures are assumed to be constant in per-capita terms for this report. Therefore, the percentage impacts would be approximately the same as for population. 
the operacing period, and 1,800 to 3,400 during decomissioning. (a) Increases in housing demand can be expected to range between 100 and 250 units, depending on available vacancies.

The absolute population and housing demand impacts of the field drywell are shown to be somewhat larger than those of the sealed storage cask concept, as can be seen by comparing the impacts in Table 5.4 with those in Table 5.5. However, in no case was the county-wide impact larger than 24 of the baseline value. This is stili considered to be below the threshold where adverse socioeconomic effects occur. If the population and housing demand growth shown in Table 5.4 or Table 5.5 was concentrated in a few smaller communities, adverse socioeconomic impacts could occur; however, this cannot be confirmed without examining real candidate sites in more detail.

\subsubsection{Public Revenues and Public Service Expenditures}

The public revenue and expenditure estimates described in Section 4.6 generally illustrate the level of impact from an MRS facilizy. Perhaps more than any uther factor in socioeccnonic impact, local government tax base and expendicure patterns depend on conditions at the site, particularly the atticudes of Fublic officials and their constituencies. The impacts shown in Section 4.6 (Table 4.19) assume typical tax bases, expenditure patterns, and leveis of public services for the regions shown, but any particular site could depart significantly from the typical pattern because of differences in state law, iocal ordinances, or local choices concerning levels of education, library, police, and other services. tiowever, the population-related expenditure impacts are similar across sites, and none is more than $\$ 5.5 \mathrm{million}$ in 1985 dollars. Moreover, in some cases Section 4.6 shows that revenue increases could be larger than the required increase in expenditures, resulting in d net public sector benefit from the facility. In generai, it is not possible to project the direction or size of net impacts on local ana state government without more specific information concerning local tax base and levels of service.

Section 4.6 shows in most cases that the increment required for public service facilities and personnel in the central county dS a result of MRS being located there is insignificant compared with increases that would likeiy occur anyway from normal population growth during the period 2985 to 2020 . This results even though 1) the size of the three impact regions is slightly different in each case, 2) che absolute size of the population impact varies by a factor of two anong the reference sites, and 3 ) the three reitererice sites are in different parts of the country. Except for very rural areas having populations significantly tess than 100,000 persons after 1995 , this result should apply to nearly any site in the country. Local exceptions may, of course, be found.

\subsection{RESOURCE REQUIREMENTS AND COST IMPACTS}

The materials required to build and operate an MRS factility are commoniy available. No large commitment ut scarce resources is required.

Costs of the MRS facility are slightly different for the two storage concepts: both costing about sl bition in present values. The sealed storage cask facility costs less to build, but that is almost exactiy offset by its higher operation costs. The cost estimates vary more among the reference sites (because of different labor and material rates) than they do between the concepts. The warm-wet reference site is the least expensive. Cost impacts on state and local government for addressing the pubiic service needs of the migrant population vary by both concept and site. The costs vary both because of the difierent levels of in-rigration necessary at the different sites and because different sites are characterized by different per capita expenditures. The projected costs would be $10 \%$ to $15 \%$ of the costs of constructing, operating, and decomissioning the MRS facility if the current level of per capita expenditures of state and local governments also applies to the incremental population.

(a) Economies experiencisig nomal growth ouring the period 1992-2021 would be larger at peak decomsissioning and should have a somewhat higher multiplier response. Offsetting this is increasillg trade and interaction between, regional economies over time, making the multiplier response smaller and the migration response larger. 
TABLE 5.4. Relationship of MRS Population and Housing Demand Impacts to Baseline Conditions, Sealed Storage Cask

\begin{tabular}{|c|c|c|c|}
\hline & & rupulacion & \\
\hline & & MRS & $\operatorname{Im} 0$ \\
\hline Year, & $\begin{array}{l}\text { Baseline } \\
\text { (persons) }\end{array}$ & $\begin{array}{l}\text { Impact } \\
\text { (persons) }\end{array}$ & $\begin{array}{c}(\% \text { of } \\
\text { Basel ine })\end{array}$ \\
\hline
\end{tabular}

1996

Central

Ario

Warm wet

Cold wet

Noncentral

Arid

Warm wet

Cold wet

Total

Arid

Warm wet

cold wet

2010

Centra?

Arid

warm wet

Cold wet

Noncentral

Arid

warm wet

cold wet

Total

Arid

warm wet

cold wet

2019

Centra 1

Arid

Warm wet

Cold wet

Noncentral

Arid

Warm wet

Cold wet

Total

Arid

Warm wet

Cold wet
124,000

144,000

161,000

153,000

910,000

$2,713,000$

277,000

$1,043,000$

$2,874,000$

144,000

151,000

169,000

201,000

$1,139,000$

$3,030,000$

345,000

$1,290,000$

$3,199,000$

163,000

169,000

186,000

248,000

$1,309,000$

$3,484,000$

411,000

$1,478,000$

$3,670,000$
2,600

200

250

1,700

150

300

450

1,550

2,650

2,150

1,700

2,950

1,550
50

100

150

150

1,700

1,200

400

1,500

2,100

3,000

1,700

2,350
1.4

0.1

0.2

0.3

0.2

0.1

0.8

0.2

0.1

1.1

$<0.1$

0.1

0.1

0.1
$<0.1$

$<0.1$

0.1
$<0.1$

1. 6

0.1

69,000

0.2

0.1

0.1

0.7

0.1

0.1

44,000

45,000

$1,053,000$

51,000

63,000

$1,109,000$

436,000

$1,275,000$

143,000

500,000

$\div, 344,000$
Housing Units Demanded

\begin{tabular}{|c|c|c|}
\hline $\begin{array}{l}\text { Baseline } \\
\text { (units) }\end{array}$ & $\begin{array}{l}\text { Baseline } \\
\text { (units) }\end{array}$ & $\begin{array}{c}\text { WRS Impact } \\
\text { (oy of } \\
\text { Baseline) }\end{array}$ \\
\hline
\end{tabular}

600

50
100

1.4

0.1

0.2

0.3

0.2

0. !

0.8

0.2

0.1

600

I,, 050

550

$<50$

50

1.2

$<0.1$

0.1

0.1

0.1

$<0.1$

385,000

250

400

$<0.1$

0. 1

600

250

450

$<0.1$

1.6

0.1

0.1

0.2

0.1

0.1

500

750

1,050

0.7

0.1 
TABLE 5.5. Relationship of MRS Population and Housfing Demand Impacts to Baseline Conditions, Field Drywell

\begin{tabular}{|c|c|c|c|}
\hline \multirow{3}{*}{$\begin{array}{l}\text { Year, } \\
\text { Site and Area }\end{array}$} & \multicolumn{3}{|c|}{ Population } \\
\hline & & MRS & MRS Impact \\
\hline & $\begin{array}{l}\text { Baseline } \\
\text { (persons) }\end{array}$ & $\begin{array}{l}\text { Impact } \\
\text { (persons) }\end{array}$ & $\begin{array}{c}\left(\begin{array}{c}* \\
\text { of }\end{array}\right. \\
\text { Basel ine) }\end{array}$ \\
\hline
\end{tabular}

Housing Units Demanded

$\frac{1996}{\text { Centrat }}$

Central

Arid

Warm wet

Cold wet

124,000

144,000

161,000

2,450
200
400

2.0

0.1

45,000

60,000

\begin{tabular}{cc}
\hline Baseijine & MRS Impact \\
(mil1ion & (mi i ion \\
$1985 \$)$ & $1985 \$)$ \\
\hline
\end{tabular}

RS Impact

Noncentral

Arrid

153,000

$65 \mathrm{G}$

910,000

2,200

Cold wet

$2,713,000$

3,700

0.4

0.2

53,000

303,000

993,000

750

1,350

0.5

Total

Arid $\quad 277,000$

Warm wet

$1,043,000$

3,100

2,400

1.1

0.2

97,000

353,000

0.1

$1,053,000$

1.3

$<0.1$

51,000

51,000

151,000

1,900
50

0.1

63,000

1,100

800

1,560

0.2

2010

Warm wet

cold wet

169,000

150

0.1

0.1

70,000

385,000

$1,139,000$

200

1,200

$<0.1$

$1,109,000$

0.7

2,100

$1,290,000$

850

1,350

0.1

121,000

436,000

$i, 172,000$

1.8

3,000

163,000

169,000

200

186,000

250

57,000

57,000

1,050
50

69,000

100

i. 3

650

$<50$
50

$<0.1$

Cold wet

248,000

400

$1,309,000$

1,500

Warm wet

Cold wet

$3,484,000$

2,250

0.2

86,000

443,000

0.1

$1,275,000$

150

550

800

0.1

250

450

0.1

$<0.1$

Total

Arid

Warm wet

411,000

3,400

$1,478,000$

1,800

0.8

143,000

500,000

0.1

$1,344,000$

1,200

600

900

0.6

0.1

$<0.1$

$\begin{array}{rr}300 & 0.1 \\ 500 & <0.1\end{array}$

Culd wet

$3,670,000$

1.8

0.1

0.1

0.2

0.1

0.1

0.8

0.1 


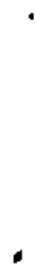

$-$ 
Bailey, W. J. 1983. "Experience with Fuel Damage Caused by Abnormal Conditions in Handling and Transporting Operations." CONF-830528-Vol. 1, pp. 802-807, in Proceedings of Packaging and Transportation of Radioactive Materials International Symposium, New Orleans, Loutsiana.

Daling, P. M., and R. L. Engel. 1983. Analysis of Near-Term Spent Fuel Transportation Hardware Requirements and Transportation Costs, PNL-4575, Pacific Northwest Laboratory, Richland, Washington.

Federal Register. 1984. "Proposed Revisions to the National Ambient Air Quality Standards for Particulate Matter," 40 Fed. Reg. 55:10408-30 (March 20, 1984).

Fleming, D. A., and K. N. Ross. 1983. Feed Materials Production Center Environmental Monitoring Annual Repurt for 1982. NLCO-1187, Cincinnati, Ohio.

Funk, C. W., and L. D. Jacobson. 1979. Inventory and Characterization of Spent L'NR Fuel, HEDL-TME 77-82. Hanford Engineering Oevelopment Laboratory, Richland, Washington.

Gainble, H. B., and R. H. Downing. 1981. "Effects of the Accident at Three Mile Island on Residential Property Vaiues and Sales." NUREG/CR 2063, U.S. Nuclear Regulatory Commission, Washington, D.C.

Groenier, W. S., R. E. Blanco, R. C. Dahiman, B. C. Finney, A. H. Kibbey and J. P. Witherspoon. 1975. Correlation of Radioactive Waste Treatment Costs and the Environmental Impact of Waste Effluents in the Nuclear Fuel Cycle for Use in Establishing "As Low as Practicable" Guides - Fabrication of Light Water Reactor Fueis Containing Plutonium. ORNL-MM-4904, Oak Ridge National Laboratory, Oak Ridge, Tennessee.

Holter, G. M., and J. L. Braitman. 1985. Siting of an MRS Facility: Identification of a Geologic Region that Reduces Transportation Requirements, PNL-5424, Pacific Northwest Laboratory, Richlana, Washington.

Kaiser Engineers (Kaiser). 1983. MRS Dry Receiving and Handling Facility (Final Report). Kaiser Engineers Hanford Company, Richland, Washingtun.

Nelson, J. P. 1981. "Three Mile Island and Residential Property Values: Empirical Analysis ano Policy Implications." Land Economics. 57:3, pp. 363-372.

Neuhauser, K. S., J. W. Cashwe11, P. C. Reardon and G. W. McNair. 1984. A Prel iminary Cost and Risk Analysis for Transporting Spent Fuel and High-Level Wastes to Candidate Repository Sites. SANO84-1795 (TTC-0506), Sandia idational Labcratories, Albuquerque, New Mexico.

Niuclear Waste Policy Act (NWPA) of 1982. Public Law 97-425.

Peloguin, R. A., J. D. Schwab and D. A. Baker. 1982. Population Dose Commitments Due to Radioactive Releases from Nuclear Power Plant Sites in 1978. NUREG/CR-2201, PNL-4039, U.S. Nuclear Regulatory Comission, Washington, $0 . C$.

Pennsylvania Department of Agriculture. 1980. "Three Mile Isiand Socioeconomic Inpact Study: A Final Report on Work Element 3." Harrisburg, Pennsyivania.

Pennsylvania Department of Conmerce. 1979. "Three Mile Island Socioeconomic Study, Work Element 4: Identification and Measurement of Impacts on Tourism Inaustry." Harrisburg, Pennsylvania.

Pennsylvania Governor's Office. 1979. "Three Mile Island Socioeconomic Impact Study." Governor's Office of Policy and Planning, Marrisburg, Pennsyivania.

Ruckwell Hanford Operations (Rockwel1). 1981. Monitured Retrievable Storage Demonstration Facility and Drywt 11 Storage Field Conceptual Design Study, RHO-BW[-C-118, RockweII Hanford Operations, Kaiser 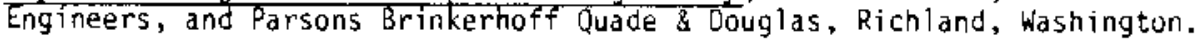

Transportation Technology Center (TTC). 1984. Nuclear Materials Transportation Appendix. SAND84-0062 (TTC-0471), Sandia National Laboratories, A]buquerque, New Mexico.

Triplett, M. B., and R. I. Smith. 1984. Evaluation of Concepts for Monitored Retrievable Storage of Spent Nuclear Fuel and High-Level Radioactive Waste. PNL-5176, Pacific Northwest Laboratory, Richland, Washington.

U.S. Code of Federal Regulations, Titie 10, Part 20.105 (10 CFR 20.105). "Permissible Levels of Radiation in Unrestricted Areas. 
U.S. Code of Federal Regulations, Title 10, Part 72 (10 CFR 72). "Licensing Requirements for the Storage of Spent Fuel in an Independent Spent Fuel Storage Installation (ISFSI)."

U.S. Code of Federal Regulations, Title 10, Part 961 (10 CFR 961). "Standard Contract for Disposal of Spent Nuclear Fuel and/or High-Level Radioactive Waste."

U.S. Code of Federal Regulations, Title 40, Part 50 (40 CFR 50). "National Primary and Secondary Anbient Air Quality Standards.

U.S. Code of Federal Regulations, Title 40, Part 51.24 (40 CFR 51.24). "Prevention of Significant Deterioration of Air Quality."

U.S. Code of Federal Regulations, Titie 40, Part 61 (40 CFR 61). "National Emission Standards for Hazardous Air Pollutants."

U.S. Code of Federal Regulations, Tit\}e 40, Part 116 (40 CFR 116). "Designation of Hazardous Substances."

U.S. Code of Federal Regulations, Title 40, Part 117 (40 CFR 117). "Determination of Reportable Quanticies for Hazärdous Substances."

U.S. Code of Federal Regulations, Title 40, Part 122 (40 CFR 122). "EPA Administered Pemit Programs: The National Pollutant Discharge El imination System; the Hazardous Waste Pernit Progran; and the Underground Injection Control Program."

U.S. Code of Federal Regulations, Title 40, Part 129 (40 CFR 129). "Toxic Pollutant Effluent Standards."

U.S. Code of Federal Regulations, Title 49, Part 173 (49 CFR 173). "Shippers--General Requirements for Shipments and Packagings."

U.S. Department of Energy (ODE). 1978. Safety Assessment Document for the Spent Fued Handling and Packaging Program Demonstration at the Nevada Test Site, NWo-198, lievada Operations Office, Mercury, Nevada.

U.S. Department of Energy (DOE). 1980. Final Environmental Impact Statement, Managenent of Comiercially Generated Radioactive Waste, Vol. 1, 00E/EIS-0046F, Washington, 0.C.

U.S. Department of Energy (OOE). 1984a. Draft Mission Plan for the Civilian Radioactive Waste Management Program. DOE-Rw-0005 draft, DOE Office of Civilian Radioactive waste Management, Washington, D.C.

U.S. Department of Energy (DOE). 1984b. Selection of Concepts for Monitored Retrievable Storage of Spent Nuclear Fuel and High-Level Radioactive Waste. DOE/RL-84-2, Richland, Washington.

U.S. Department of Transportation (DOT). 1979. Highway Statistics 1979. Washington, D.C.

U.S. Environmental Protection Agency (EPA). 1980. Radiological Impact Caused by Emissions of Radionuclides into Air in the U.S., Preliminary Report. EPA 520/7-79-006, Washington, D.C.

U.S. Nuclear Regulatory Comission (NRC). 1972. Assumptions Used for Evaluating the Potential Radiological Consequences of a Fuel Handling Accident in the Fue Fandling and Storage FaciTity for Boiling and Pressurized Water Reactors. NRC Regulatory Guide 1.25, Washingtun, D.C.

U.S. Nuclear Regulatory Comission (NRC). 1975. Operating Philosophy for Maintaining Occupational Radiation Exposures as Low as is Reasonably Achievable. U.S. Nuclear Regulatory Commission, Regulatory Guide 8.10 Rev. 1., Washington, 0.C.

U.S. Nuclear Regulatory Commission (NRC). 1979. Assumptions Used for Evaluating the Potential Radiological Consequences of Accidental Nuclear Criticality in a Uranium Fuel Fabrication PJant. Regulatory Guide 3.34, Nashington, D.C.

U.S. Nuclear Regulatory Commission (NRC). 1980. Final Generic Environmental Impact Statement on Uranium Milling, Project M-25, NUREG-0706, Vol. 1.

Wilmot, E. L., M. Madsen, W. Cashwell and S. Joy. 1983. A Preliminary Analysis of the Cost and Risk of Transporting Nuclear Waste to Potential Candidate Comercial Repository Sites, SAND 83-0867, Sandia Nationat Laboratories, Abuquerque, New Mexico. 
background radiation - the level of radioactivity from naturally occurring sources; principally radiation from cosmogenic and primordial radionuclides

backup MRS facility - an MRS facility to be constructed only if there is a significant delay in the repository program

berm - an engineered mound of earth designed to provide shielding, physical protection, constraint, security and/or thermal insulation

biota - the animal and plant life of a particular region

blowdown - the water that is purged from a system and is replaced with fresh water to prevent the buitdup of chemicals in the systern

caliche - an accumulation of calcareous material fomed in soil or sediments in arid regions

canister - container for high-activity waste such as Sr or Cs capsules or vitrifjed wastes

cask - a container designed for transporting and/or scoring radioactive materials; design usually includes special shielding, handing, and sealing features to provide positive containment and minimize personne $i$ exposure

Code of Federai Regulations (CFR) - a documentation of the regulations of federal executive departments and agencies, which is divided into 50 titles representing broad areas subject to feoeral regulation; eaci title is divided into chapters, which are further subdivided into parts

contact-handled (CH) waste - TRU waste, usually packaged in some form, which emits low enough radiation levels (less than $200 \mathrm{mR} / \mathrm{hr}$ ) to permit close and unshielded manipulation by workers

contamination (contaminated material) - the deposition, solvation, or infiltration of radioriuclides on or into an object, material, or area; the presence of unwanted radioactive materials or their deposition, particularly where it might be harmful

controlled area - any specific region of a site into which entry by personnel is regulated by pinysical barrier and/or procedure

curie ( $C i$ ) - a unit of radioactivity defined as the amount of a radioactive materia! that has an activity of 37 billion $\left(3.7 \times 10^{10}\right)$ disintegrations per second $(\mathrm{d} / \mathrm{s})$; millicurie (mCi) $=10^{-3}$ curie; microcurite $(\mu \mathrm{C} i)=10^{-5}$ curie; nanocurie $(n C i)=10^{-9}$ curie; picocurie $(p C i)=10^{-12}$ curie; fentocurie (fCi) = $10^{-15}$ curie; megacurie $(M C i)=10^{6}$ curie

decay, radioactive - a spontaneous nuclear transformation of one nuclide into a different nuclide or into a different energy state of the same nuclide by emission of particles and/or photons

decay heat - heat geferated by radioactive decay in spent fuel or components

decay products - the imnediate product of radioactive decay of an elenent; also called radioactive decay products

decommissioning - actions taken to reduce the potential health and safety impacts of surpius facilities, including activities to stabilize, reduce, or remove radioactive contamination; the removal from service, at the end of its useful life, of an MRS facility and its related components in accordance with regulatory requirements and environmental policies

decontanination - the removal of radioactive contamination from facilities, sojis, or equiprent by washing, chemical action, mechanical cleaning, or uther techniques

design basis accident - a postulated accident believed to have the most severe expected impacts on a facility; used as the basis for structural design of a facility and for safety analyses

oisintegrations per minute (dpm) - the number of radiodctive decay events occurring per unit time in a given amount of material

dispersion - phenumenon by which a material placed in a flowing medium gradually spreads and uccupies an ever-increasing portion of the flow domain 
disposal - the planned release of radioactive and other waste or its placenent in a manner which is considered permanent so that recovery is not provided for (i.e., repository)

dose conmitment - the integrated dose which results from an intake of radioactive material when the dose is evaluated from the beginning of intake to a later time (usually 50 to 70 years); also used for the long-tem integrated dose to which people are considered committed because radioactive material has been released to the environment

dose equivalent - a means of expressing dose (in rem) that provides a consistent estimate of dose effectiveness regardless of the rate, quantity, source, or quality of the radiation (often referred to simply as dose)

dose rate - the radiation dose delivered per unit time

dosimeter - a Gevice, such as $\mathrm{film}$, thermoluminescent material, or ionization chamber, that measures radiation dose over a given period; these devices are worn or carried on a person's buay co record radiation dose

orum - a metal cylindrical container used for the transportation, sturage, and disposal of waste materials arywell - a dry, sealed, mecal-lined hole in the ground for safely storing a canister of radioactive waste ecology - that branch of biological science that deals with the study of relationships between organisms and their environment

ecosystem - an assemblage of biota and habitat

engineered barrier - an addition to a disposal site that is designed to retard or preclude radionuclide transport and/or to preserve the integrity of the disposal site

environmental surveillance - a program to monitor the effects on the surrounding region of the discharges from industrial operations

exposure - the condition of being made subject to the action of radiation; a measure, in roentgens, of the ionization produced in air by $x$-ray or gama radiation

feral - existing in a natural state

food chain - a linear sequence of successive utilizations of nutrient energy by a series of species

food web - the cuncept of nutrient energy transfers (including decomposition) between species in an ecosysteril

fuel assembly - a group of fuel rods, pins, plates, etc., held together by structural components; also called fuel bundle, fuel rod cluster, and fuel element

fuel rod - a basic component of nuclear fuel, such as a tube, element on other fum, into which nuclear fuel is fabricated for use in a reactor; also called fuel pin

ground water - water that exists or flows below the surface (within the zones of saturation)

grout - a fluid mixture of cement, water, fly ash and clay that sets up as a solid mass and is used for waste fixation or imobilization

habitat - the characteristics of the place where biota live

hazardous waste - usually means nonradioactive chemical toxins or othenwise potentially dangerous materiais such as sodium, heavy metals, beryllium, and some organics

HEPA - high-efficiency particulate air (filter); material (usually a paper or fiber sheet pleated to increase surface area) that captures entrafned particles from an air stream, usually with efficiencies of $99.95 \%$ and above

high-level waste (HLW) - the highly radioactive waste material that results from reprocessing spent nuclear fuel, including liquia waste produced directly in reprocessing and any solid waste derived from the liquid, that contains a combination of TRU waste and fission products in concentrations as to require permanent isolation; also, other highly radioactive material that the NRC determines requires permanent isolation

hot cell - weli-shielded enclosure for remote operations, such as handing, processing and/or investigating radioactive materjal 
inadvertent intrusion - human activity such as home excavation, resource mining, and well digging that accidentally breaches a waste site

integral MRS facility - an MRS facility that would be an integral part of the repository prograrn and that would receive, handle, and package spent fuel for disposal

interim storage - storage of radioactive material such that: isolation, monituring, protection of humans, and human control are provided; and subsequent action involving treatment, transportation, and disposal or reprocessing is expected

lag storage - temporary storage for spent fuel to accomodate fluctuations between process sceps

leach - to dissolve out the solubie components of a solid by contact with water or other solvent

1 imited access area - a security area for the protection of classified matter where yuaros, security inspections or other internal controls can prevent access by unauthorized persons

luess - a nomogeneous, nonstratified, unindurated sediment, largely silt, mainiy deposited by the wind

low-level waste (LLW) - radioactive waste not classified as high-level waste, TRU waste, spent ruclear fuel, or by-product material; generaliy contains no more than 10 nanocuries of transuranic material per gram of waste and requires little or no biological shielding

maximum (or maximally exposed) individual - a hypothetical member of the public whose habits tend to maximize radiation dose to a given organ; for the case where exposures from airborne radionuclides result in the highest contribution to dose, this individual is assumed to reside continuously at the location of highest airborne radionuclide concentration and to eat food grown there

metric ton (or tonne) - 1,000 kilograms; 2,205 pounds

near surface - a location designation for waste not disposed of in deep geologic repositories

nuclear radiation - particles and electromagnetic energy given off by transformations occurring in the rucleus of an atom

offsite - any place outside a site boundary

packaging - assembly of radioactive material in one or more containers

particulate - generally refers to particles in an aerosol stream; usually can be removed by filtration

person-rem - the product of the dose equivalent in rem and the number of people receiving that dose, a collective population dose

$\mathrm{pH}$ - a measure of acidity and alkalinity, neutrality being at $\mathrm{pH} 7$; $\mathrm{pH}$ under 7 indicates an acid solution and $\mathrm{pH}$ over 7 indicates an alkaline solution; log reciprocal of the hydrogen ion concentration

$\mathrm{PM}_{10}$ - particle with an aerodynamic diameter of smaller than or equal to a nominal I0 micrometers

population dose (population exposure) - sumation of individual radiation dose received by all those exposed to the source or event being considered

rad - unit of absorbed dose equal to 0.01 joules per kilogram in any medium

radiation (ionizing) - particles and electromagnetic energy emitted by nuclear transformations that are capable of producing ions when interacting with matter

radiation monitoring - a term covering application of a field of knowledge including determination of dose rates, surveys of personnel and equipment for contamination control, air sampling, exposure control, etc.

radiation survey - evaluation of an area or object with instruments in order to detect, identify and quantify radioactive materials and radiation fields present

radioactive waste - solid, liquid, or gaseous material of negligible economic value that contains radionuclides

radioactivity - the property of certain nuclides of enitting particles or electromagnetic radiation while undergoing nuclear transformations 
radiwaste - see radioactive waste

regolith - rock "waste" or surface mantle of unconsolidated rock debris

rem - the special unit of the dose equivalent; the radiation dose equivalent in rem is numerically equal to the absorbed dose in rao at the point of interest in tissues, multipliea by a quality factor, distribution factors, and ail other modifying factors; one rem approximately equals one rad for $x$, garma, or beta radiation

remote-handled (RH) waste - TRU waste having a surface dose rate greater than $200 \mathrm{mR} / \mathrm{hr}$ and requiring shielding from and distance between it and human manipulators

repository - a facility consisting primarily of mined cavities in a deep geologic medium and associated support facilities for the permanent disposal of spent fuel and high-level waste

reprocessing - the mechanical and chemical treatment of spent reactor fuel to recover useful materials such as thorium, uranium, and plutoniunil (uther raoioactive materials are usually separated anu treated as waste)

retrievably stored - interim stored waste that is retrievable with minimal risk and cost for further frocessing and/or disposal

rod consolidation - the disassembly and packaging (reconfiguration into a close-packed array) af spent fuel rods to achieve volume reduction, thereby 1 imiting the space required for storage or disposal

roentgen - a unit of measure of ionizing electromagnetic radiation (exposure) (x-rays and gamma rays); one roentgen corresponds to the release by ionization of 83.8 ergs of energy per gram of air

shielding - walls or other constructions used to absorb radiation in order to protect personnel or equipment

shipping cask (transport cask) - a cask with a protective covering that contains and shielas radiudctive materials, dissipates heat, prevents damage to the contents, and prevents criticatity during nonkal shipment and accident conditions

siting - the testing, evaluation, and institutional activities associated with the process if site screening, site recomrendation, and site approval for evaluation or development

solid waste (radiadive) - either solid raoidactive material or solid objects that contain radioactive material or bear radioactive surface contamination

spent nuclear fuel - fuel that has been withdrawn from a nuclear reactor following irradiation, whose constituent elements have not been separated by processing

storage - retention of waste in a retrievable manner that requires surveillance and institutional control

storage site - area dedicated to waste storage and related activities

surveillance - those activities to ensure that stored radiodctive material remains sate (including inspection and monitoring of the site, maintenance of access barriers to radioactive naterial left on the site, and prevention of activities on the site that might impair these barriers)

throughput rate - average rate at which an MRS facility can receive, process, and/or ship spent fuel or high-Tevel waste

transporter - a vehicle to move sealed storage casks or waste canisters at an MRS facility

transuranic (TRU) waste - without regard to source or form, radioactive waste that at the end of institutional control periods is contaminated with alpha-emitting transuranium radiunuclides with half-lives greater than 20 years and concentrations greater than $100 \mathrm{nCi} / \mathrm{g}$

vadose zone - the unsaturated region of soil between the ground surface dnd the water table

vault - a type of solid waste storage structure, usualiy a concrete-lined, covered in-ground pit

water table - upper boundary of an unconfined aquifer surface below which saturated groundwater occurs; defined by the levels at which water stands in wells that barely penetrate the aquifer 
APPENOIX A

STURAGE DESIGN CONCEPTS NOT SELECTED FOR DETAILED ANALYSIE 


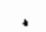

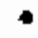

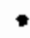




\section{CONTENTS OF APPENDIX A}

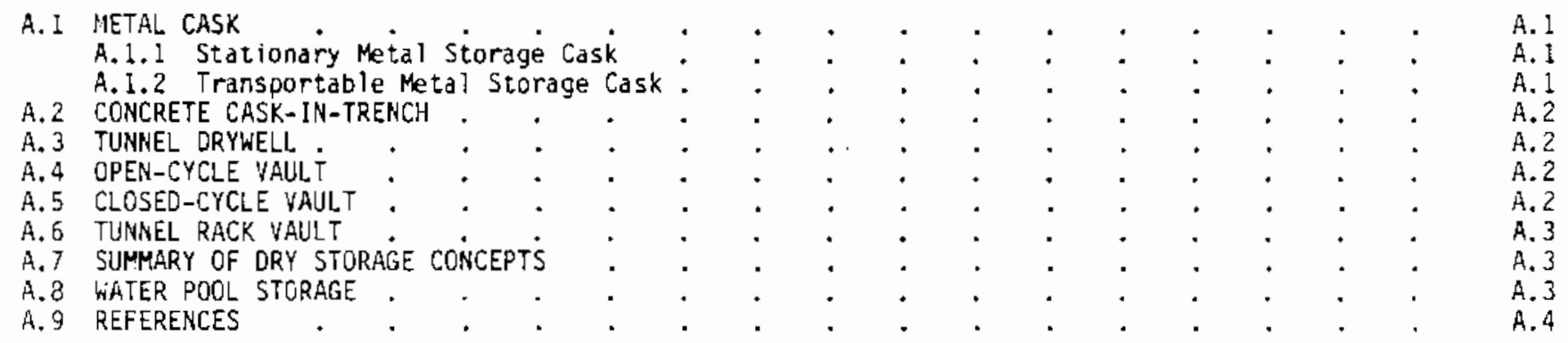




\section{STORAGE OESIGN CONCEPTS NOT SELECTED FOR DETAILED ANALYSIS}

Brief discussions of the characteristics of each of the concepts not selected for further design development are in this appendix. For more detailed information, refer to the respective concept selection reports listed in the Reference section.

\section{A. 1 METAL CASK}

For the metal cask concept, two facility types were examined: a stationary-storage-cask facility and a transportable-storage-cask facility.

\section{A.1.1 Stationary itetal Storage Cask}

A stationary-inetal-storage-cask MRS facility (Westinghouse 1983a) uses large metal casks for storing canisters of spent fuel or solidified reprocessing wastes. The facility consists of five princtpal components in addition to the R\&H facility. These components are:

- Large metal casks in which the spent fuel or reprocessing wastes are stored. The cask has sufficient shielding (steel, lead, water) to keep the radiation levels at the exterior of the loaded cask at acceptable values, and has heat transfer capabilities adequate to keep the temperatures in the stored radioactive material at acceptable levels. Double seals provide redundant containment of the canistered material within the cask.

- An onsite transporter to carry the loaded storage casks from the R\&H facility to the storage area and to return the casks to the Rati facility when retrieval is initiated.

- A mobile crane to transfer the loaded cask from the transporter to the scurage pad (and back again for retrieval).

- A suitable foundation (such as a reinforced concrete pad) for storing arrays of casks.

- A system for monitoring the integrity of the cask seals and for detecting releases of radioactive material from the stored canisters to permit correction before release from the cask can occur. Area monitoring is also provided to monitor site conditions outside of the casks.

A typical metal cask is about $2.5 \mathrm{~m}$ in diameter and $5 \mathrm{~m}$ in height and weighs somewhat less than 100 tons. Heat from the radioactive decay of the stored material is conducted through the metal cask wall and transferred to the atmosphere by surface convection and thernal radiation.

The casks are stored in a secured, fenced area to minimize intrusion. Depending upon the climatology at the site, the storage area could be in the open or could be enclosed within simple structures.

\section{A.1.2 Transportable Metal Storage Cask}

The transportable metal storage cask(a) (Westinghouse 1983b) is a stationary metal cask with added overpacks and impact limiters as required to license the cask for transport while loaded with radioactive material. The cask is received at the MRS site on a rajlcar, placed on a transporter for delivery to the storage area, and placed on a storage pad using a crane. Removal from storage is the reverse of these steps.

The transportable metal cask can be used to ship and store unconsolidated spent fuel, either canistered or uncanistered, canistered consolidated spent fuel, and canistered HLW. The R\&H facility is much reduced in size and scope from that needed for the other concepts, because it is only needed for routine receiving, handling, inspection and washdown of the incoming casks and for the decontarnination and repair of an occasional leaking canister. No consolidation capability was provided in the case studied, since spent fuel will be stored in its as-received condition. In essentially all other aspects, the transportable cask concept is identical to the stationary cask concept.

(a) The transportable metal cask was evaluated only for its potential role as an MRS facility. It was not evaluated as an at-reactor storage option. 


\section{A. 2 CONCRETE CASK-IN-TRENCH}

A variant of the sealed storage cask concept selected as a storage concept for the MRS facility is the cask-in-trench (Boeing 1983a). In this concept, a cask similar in configuration to the concrete cask is placed in a trench (or berm) that is subsequently backfilled level with the top of the cask.

\section{A.3 TUNNEL DRYWELL}

A tunnel drywell MRS facility (Westinghouse 1983c) utilizes underground storage of spent fuel or reprocessing wastes in drywells located within a mined tunnel. This facility consists of the same najor components as the field drywell.

The spent fuel or reprocessing waste is sealed in canisters placed by a shielded transporter into dryweils set in the floors of tunnels. The surrounding rock attenuates ruclear radiation and dissipates decay heat.

\section{A.4 OPEN-CYCLE YAULT}

An open-cycle vault MRS facility (Boeing 1983b) utilizes a large, shielded warehouse for storing canisters of spent fuel or reprocessing wastes. The facility consists of four major components in addition to the RaH facility. These components are:

- A large building with thick concrete shielding to house the canisters of spent fuel or reprocessing wastes. The storage area can be above or below ground level. Large-volume ventilation stacks wili extend above the building.

- A crane or other mechanical transporter to move the canistered spent fuel or reprocessing waste to the storage location and to place any additional covers on the canisters. The same system is used to retrieve the canisters from storage. The canisters are placed vertically in storage tubes that keep then stable. The storage tubes are sealed after loading, which provides a redundant barrier to the sealed canisters.

- A system of air ducts that directs outside air around the storage tubes for cooling then discharges the air to the atmosphere. The large volume of air flow requires no biowers; it is induced by the natural draft caused when the heat from the containers is transferred to the air.

- A system for monitoring the air inside the storage tubes and the air fluw through the vault fur detecting any leakage of radioactive material from the metal canisters.

In the open-cycle vault concept, the barriers to prevent radioactive materiai releases to the atmosphere are the steel canister and the sealed sturage tube. The facility is contained within a secured, fenced area to minimize intrusion.

\section{A.5 CLOSED-CYCLE VAULT}

Closed-cycle vaults (GA Technologies 1984a) are similar to open-cycle vaults in that both concepts typicaliy provide relatively large, shielded enclosures for starage and both rely on natural circulation of air to remove the decay heat from the stored radioactive material. Closed-cycle vaults differ from opencycle vaults in that decay heat is transferred from the stored material through an overpack and the concrete shielding to natural convection cooling ducts in the concrete and then through heat pipes from the cooling ducts to the outside air.

Several different closed-cycle vault designs have been developed for dry storage of spent fuel and reprocessing wastes. The facility consists of five principal components in addition to the Rs facility. These components are:

- Multiple concrete storage nodules each containing nine locations for storage of radioactive materials. Heat pipes in combination with cooling passages in the concrete dissipate the heat passively to the air by natural convection.

- Large sealed overpack containers that can accomadate multiple spent-fuel or waste canisters.

- A transfer cask for transporting the loaded overpack containers from the R\&H facility to the storagemodule loading machine.

- A storage-module loading machine that transports the overpack container to the storage location, inserts it into the storage module, and then retrieves it when needed. 
- A system for detecting releases of radioactive material from the overpack containers. The facility is enclosed within a secured, fenced area to minimize intrusion.

\section{A. 6 TUNNEL RACK VAULT}

The tunnel rack vault MRS facility concept (GA Technologies I984b) uses the same natural draft cooling principle as the open-cycle vault. The facility consists of five principal components in addition to the RoH facility. These are:

- Canister storage racks that are unshielded and transportable.

- Remotely operated transfer machines for moving the lodded storage racks from the hot cell to the storage tunnels and for returning the racks to the hot cell for unloading.

- Storage tunnels, which are accessed from a main transfer tunnel, preferably in a hill near and at the same elevation as the RRti facility.

- Ventilation tunneis with air passages for the natural convective cooling of the stored radioactive material.

- A system for continuous monitoring of air to detect leakage of radioactive material from the stored canisters and a visual monitoring system with remotely controlied cameras.

The facility is enclosed within a secured, fenced area to minimize intrusion.

\section{A. 7 SUMMARY OF QRY STORAGE CONCEPTS}

Environmental impacts associated with these six concepts not selected are minor and certainly controliable. Common to all of them is the clearance of the site of the natural vegetative cover to be replaced by structures and/or activities. This will result in an increase in ambient dust, especially during the construction phase. During construction and some phases of operation, there would be an active excavation and removal of earth as wells are dug, bed is prepared, etc. This will necessitate disposal of this material and a concomitant impact where it is disposed.

Aquatic resources impacted should be mininal. Water for site construction and for bullding the concrete casks (for that concept) will be needed, and this impact may or may not be significant, depending largeiy on the characteristics of the water source. Operation of most concepts entails a washdown facility for deccntanination and cleaning of the waste canisters when they are received; disposal of this water will normally be to the sanitary disposal system and should not adversely impact the environment.

\section{A.8 WATER POOL STORAGE}

Facilities used for water pool storage of spent nuciear fuel are similar to one another, with only minor equipment and configuration variations. Storage of solidified HLW is basically the same as storage of spent fuel elements, but with different contents and configurations. The storage area is comprised of reinforced concrete pools that ma be covered or left open to the storage building. Each pool is lined with stainless steel for water and radionuclide containment, for water chemistry control, and for ease uf decontamination.

Operation of a water pool facility for storage of spent fuel requires the coordination of several systems from receiving to waste treatment. Operations at a water pool storage facility include:

- shipping and receiving

- cask washdown and cooling

- cask urioading (into pooi)

- decontamination

- transfer and storage in pools

- pool water cleanup, including filtration and deionization, heat removal, and waste and effluent handling.

Semi-remote operations are perfomed under water where they can be seen and controlled from above. The pool water and the shipping cask provide radiation shielding for workers.

Water pool storage was not evaluated in this analysis because only methods of passive, dry storage were considered. 


\section{A. 9 REFERENCES}

Boeing Engineering Company. 1983a. MiRS Conceptual System Study: Cask in Trench. BEC-MRS-3303, Seattle, Hashington.

Boeing Engineering Company. 1983b. MR5 Coneptual System Study: Open-Cycle Vault. BEC-MRS-3304, Seattle, Washington.

GA Technologies, Inc. 1984a. MRS Conceptual System Study: Closed-Cycle Vault. GA-A17322, San Diego, California.

GA Technologies, Inc. 1984b. MRS Conceptual Study: Tunnel Rack Vault. GA-Al7323, San Diego, California. hestinghouse Electric Corporation. 1983a. MRS Conceptual System Study: ietal Storage Casks. NTSD-10-010, Pittsburgh, Pennsylvania.

Westinghouse Electric Corporation. 1983b. MRS Conceptual System Study: Transportable Storage Casks. WSTO-TME-013, Pittsburgh, Pennsylvania.

West inghouse Electric Corporation. 1983c. MR5 Conceptual System Study: Tunnel Drywells. WTSD-TME-D12, Pittsburgh, Pennsylvania. 
APPENDIX B

ENVIRONMENTAL IMPACT ANALYSIS 


\title{
CONTENTS OF APPENDIX B
}

\begin{abstract}
B.1 CONSTRLICTION .
B.2 OPERATIONS

B.3 TRANSPORTATION.

B.4 OECOMMISSIONING

B. 6 DOSIMETRY

- $\quad$ B.7 TOXICITY OF PROCESS MATERIALS.

B.8 REFERENCES.
\end{abstract}

\section{TABLES}

B.1 Estimated Enissions During Construction of an MRS Facility

B.2 Nonradiological Enissions from Operation of an MRS Facility

B.3 Radiological Unit Factors

B.4 Percentage of Trave? in Each Population Zone.

B.5 Nonradiological Unit Factors for Accidents.

B.6 Total Transportation Distarices

B.7 Arid Site Annual Average Dispersion Factors for Ground-Levei Releases.

B.B Warm-Wet Site Annual Average Dispersion Factors for Ground-Level Releases

B.9 Cold-Wet Site Annual Average Dispersion Factors for Ground-Level Releases

8.10 Sumary of Population Dispersion Factors at Ground Level

B.11 Sumary of Dispersion Factors for the Maximum Individual for Routine

8.12 Dispersion Factors for the Maximum Individual for Actue Release at Ground Level

B.13 Toxicity Rating Scale

B.14 Toxicity and TEV of Process Chemicals to be Used at an MRS Facility.

8.1

B. 3

B. 4

B. 4

B. 4

B. 5

B. 6

B. 7

B. 8

B. 9

B. 9

B. 9

B. 10

B. 11 


\section{ENVIRONMENTAL IMPACT ANALYSIS}

The mathematical models and computer programs used in calculating potential radiation doses and nonradiological impacts for the six alternative site/concept combinations are discussed in this appendix. The computer programs have been documented separately; therefore, oniy brief sumaries will be presented here. Because no contaminated liquid releases have been defined for the MRS facility, only impacts from gaseous effluents to the atmosphere and direct radiation from transportation are addressed.

\section{B.1 CONSTRUCTION}

Nonradiological enissions from construction of the facility consist mostly of fugitive dust and colnbustion products from heavy diesel equipment. Estimated emission rates for either storage concept at the three sites are given in Table B.1. Emissions of fugitive dust are much higher at the ario site, which has less rainfall.

TABLE B.1. Estimated Emissions During Construction of an MRS Facility (kg/mo)

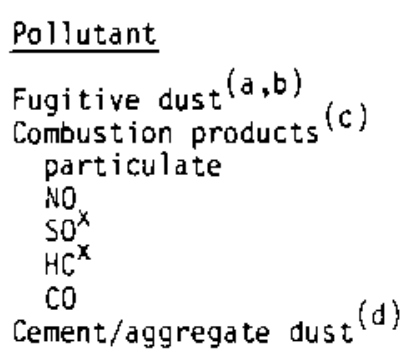

\begin{tabular}{|c|c|c|}
\hline Arid & harm wet & Cold wet \\
\hline 25,000 & 10,000 & 10,000 \\
\hline $\begin{array}{r}140 \\
2,200 \\
140 \\
160 \\
430 \\
500\end{array}$ & $\begin{array}{r}140 \\
2,200 \\
140 \\
160 \\
430 \\
500\end{array}$ & $\begin{array}{r}140 \\
2,200 \\
140 \\
160 \\
430 \\
500\end{array}$ \\
\hline
\end{tabular}

(a) Based on dust emissions per acre for 50 acres of active heavy construction, with emission facturs from AP-42 (Mann and Cowherd 1977), corrected for precipitation inaex. Credit of $50 \%$ is taken from surface watering at the arid site.

(b) Fugitive dust, defined as diameter equal to or less than 30 um. Proposed regulations are based on particles with aerodynamic diameter eoual to or less than $10 \mathrm{im}$ (Federal Register 1984).

(c) Combustion emissions based on consumption of $10,000 \mathrm{gal} / \mathrm{mo}$ diesel fuel; same site preparation requirements assumed at each site. Emission factors for miscellaneous heavy equipment from AP-42 (Kircher 1975).

(d) Estimated from concrete required for construction.

Oisturbed area of heavy construction operations is caken to be an average of 50 acres, about that of the R\&H and site facilities construction area. The actual size of the area under construction varies with the construction schedule; about four months for clearing, grubbing, and rough gradirig the construction ana plant areas (about 40 and 90 acres), about four months for rough grading the storage area (65 acres for cask facility). Additional tine is spent continuing to survey, clear, and grub. Concurrently, storage pads are formed and poured.

The waste storage area for the two concepts differs greatly; the ultimate size of the storage area of a 15,000 MTU concrete storage surface cask facility is 64 acres, versus 227 and 165 acres for a field drywell type facility at arid or wet sites, respectively. The drywell facility, having a larger area, may emit more dust over the construction period, but the maximum concentration for a particular site is assumed to be about the same.

Emissions of fugitive dust are based on $1,000 \mathrm{~kg} / \mathrm{ac} /$ mo for heavy construction for the arid site (Mann and Cowherd 1977). Reduced amounts, adjusted by Thornthwaite's precipitation index (Mann and Cowherd 1977) are estimated for the wet sites. The fugitive dust estimates take no credit for wetting or using surface stabilizers, except at the arid site where twice daily wetting is assumed to reouce fugitive dust emissions by $50^{\alpha}$. 
A large concrete batch plant will be constructed on the site for use during the construction phase of the project. This plant will be much larger than the cask manufacturing plant, and will operate only during construction. It will be torn down after completion of the initial construction.

A concrete collar is installed around each drywell at the drywell facility. The depth of the collar is 6 inches below frostline, which is 30 inches for the arid site, 18 inches for the warmi-wet site, 42 inches for the cold-wet site. A small amount (relative to cask manufacturing) of concrete batchtng is done at this facility.

Emissions from combustion of fuel are based on equal fuel consumption rates at either type of facility or location. Resultant concentrations will differ by application of different site-specific dispersion factors (Section B.5).

\section{B.2 OPERATIUNS}

Radiological impacts during the operating phase may result from nomal or abnormal conditions. Methods for calculating public exposure during this phase are outlined in this section.

Nomal releases of activity to the atmosphere may result in offsite public exposures. Pathways of interest include: I) external exposure to the plume, 2) inhalation of the plume, 3) external exposure to aeposited activity, and 4) ingestion of food products cantaminated by aeposited activity. The computer program ALLDOS (Strenge et al. 1980) is used to estimate maximum individual and population doses from these pathways. This prograrn uses inhalation dase factors generated by the OACRIN computer prograrn (Houston, Strenge and watson 1976) and terrestrial pathway dose factors from the PABLM computer progran (Napier, Kennedy and Soldat 1980). Details of the use of these programs and site-specific data are presenteo in Sections B.6 and B.7. Estimates of atmospheric dispersion parameters are made using the computer program X0000Q (Sagendorf, Goll and Sandusky 1982) as described in Section 8.5.

Abnommal releases are generally of short duration and require somewhat different methods to estimate public exposures. Atmospheric dispersion for short-tem releases are estinated using the computer program PAVAN (Bander 1982). This program implements the methods of Regulatory Guide 1.145 (NRC 1979 ) in estimating the frequency of occurrence of time-integrated air concentration ( $E / Q$ ) at specific locations about the site. For this study, a fenceline distance of $175 \mathrm{~m}$ was assumed for the sealed storage cask concept and 335 in for the field drywell concept. These distances were used for all three sites. Results of the dispersion calculation are given in Section B.5. The same exposure pathways are considered for abnormal releases as for nomal releases. The caiculations are made using the ALLDOS, DACRIN, and PABLM Computer prograns (as described in Chapter 4.0) with input parameters modified to reflect an acute exposure situation.

Nonradiological emissions from nornal operation of the MRS facility are primarily from combustion of fossil fuels. Annual consumption of No. 2 fuel oil is estimated to be 950,000 gallons per year, with a maximum winter consumption rate of 239,000 galions per month. In addition, 95,000 galluns of diesel fuel and 60,000 galions of unleaded gasoline are used by vehicles.

Fugitive dust emissions during operation may originate from aggregate storage and cask manufacturing for the concrete storage cask type facility. Since construction of the starage area is complete before operation, minimal dust will originate from roads, which are either paved or covered with aggregate.

Estimated emissions of pollutants are given in Table B.2, based on maximum use rates of fuel and maximum areas of activity.

\section{B.3 TRANSPORTATION}

The caiculation of collective dose to the general pubiic from transportation is based on the niethods developed by the Transportation Technology Center (TTC) as described by wilmot et al. (1983). This reference presents "radiological unit factors" and "nonradiological unit factors" that relate total transport distance to risks. Radiological risks (whole-budy exposure) and nonradiological risks (pollutants) from nomal operations are estimated. An estimate of potential public exposures from accidents is also provided based on an accident probability and severity analysis. Nonraoiological risks from accidents (injuries and fatalities) are based on transportation statistics. 
TABLE B.2. Nonradiological Enissions from Operation of an MRS Facility (kg/mo)

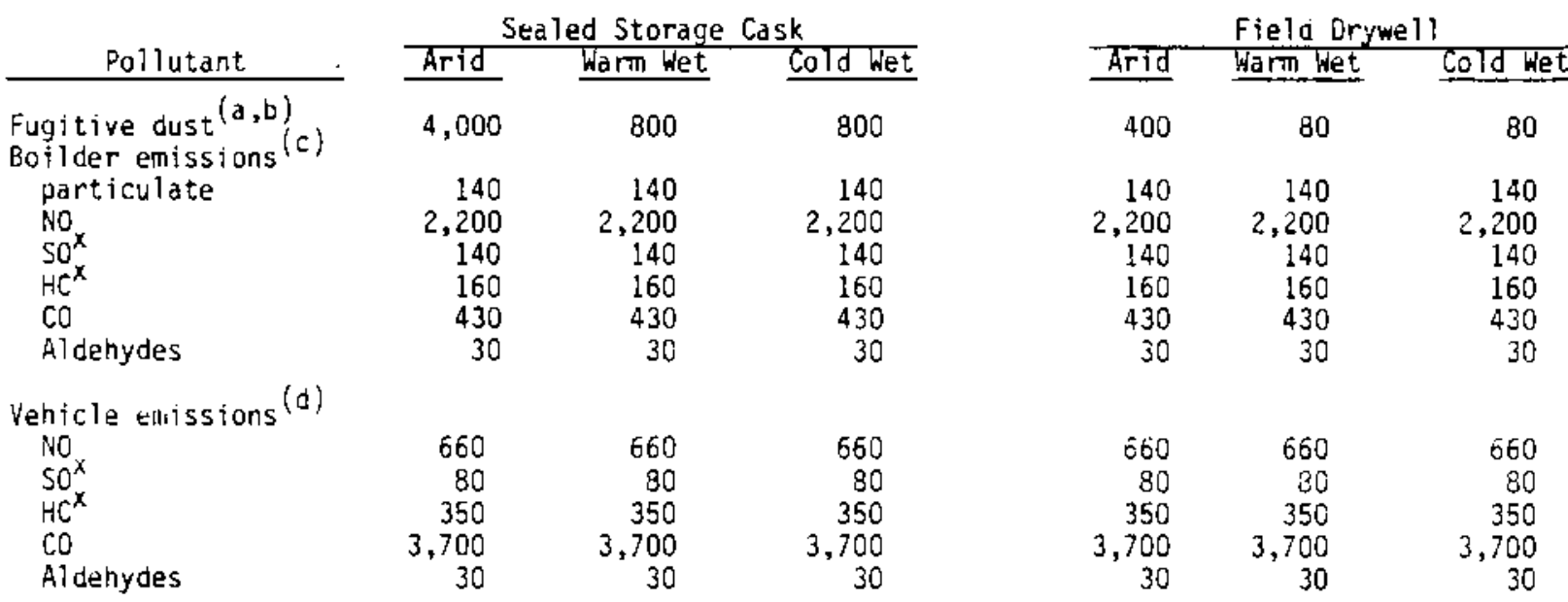

Ta) Based on dust emissions for concrete batching and aggregate storage (Mann ana Cowherd 1977) for concrete storage cask facility and concrete batching for collars for the drywell facility. No credit taken for watering or stabilization.

(b) Fugitive dust, defined as diameter equal to or less than $30 \mu$ m. (Proposed regulations are based on particles with aerodynanic didmeter equal to or less than $10 \mu m$ ).

(c) Boiler emissions based on consumption of $239,000 \mathrm{gal} / \mathrm{mo}$ No. 2 fuel $0 \mathrm{il}$; enission factors for industrial boilers from AP-42 (Lahre 1977).

(d) Vehicle emissions based 8,000 gal/mo diesel fuel plus 5,000 gal/mo gasoline and factors from Kircher and Willians (1975).

The radiological unit factors are used for a given site and transport rnode (rai] or truck) by the following equation:

$$
D_{\text {es }}=\sum_{w=1}^{N} \sum_{t=1}^{N} D_{t w s} s_{t w s} \sum_{z=1}^{N} P_{t z s} U_{t w e z}
$$

where $D_{e s}$ is the collective dose to exposure group e for transport to site 5 , person-rem

$0_{\text {tws }}$ is the distance per shipment for transport mode $t$ and waste-type $w$ for transport to site s, km

$S_{\text {tws }}$ is the number of shipments of waste-type $w$ by transport node to site $s$

$P_{\text {tzs }}$ is the fraction of distance traveled in population zone $z$ for transport mode $t$ to site $s$

$U_{\text {twez }}$ is the radiological unit factor for transport mode $t$, waste-type $w$, exposure group e in population zone $z$, person-rem, $\mathrm{km}$

$N_{W}$ is the number of waste types considered

$N_{t}$ is the number of transport modes considered

$N_{z}$ is the number of population zones considered.

The radiological unit factors are defined for truck and rail transport of various waste types through rural, suburban, and urban populations. These values were calculated using the RADTRAN-II computer prograti (Taylor ana Caniel 1982; Madsen, wilmot and Taylor I983). Values used in this study are given in Table B. 3 as presented in Wilmot et al. (1983). To estimate the transportation doses, the fraction of total distance traveled in each of these three population zones $\left(P, P_{\text {f }}\right)$ must be defined. Table $B .4$ shows fractional travel in each population zone for both truck and rail trahsport to the MRS and from the MRS to a repository. Because a repository site has not been chosen, values for a nearby and a distant repository site are presented to provide a range of potential consequences.

Nonradiological risks, including deaths and injuries from accidents, result regardess of the radiological characteristics of the load. Table B.5 gives nonradiological unit factors for both fatalities and injuries during transport for truck and rail nodes. 
TABLE B.3. Radiological Unit Factors (person-rem/km)

\begin{tabular}{|c|c|c|c|}
\hline \multirow[b]{2}{*}{ Transport Mode/Waste Type/Exposed Group } & \multicolumn{3}{|c|}{ Unit Factors by Population Zone } \\
\hline & Rurâ & Suburtian & Unan \\
\hline \multicolumn{4}{|l|}{ Truck Transport } \\
\hline $\begin{array}{l}\text { Spent Fuel } \\
\text { Nonmal - public } \\
\text { Slomal - occupational } \\
\text { Accident - public }\end{array}$ & $\begin{array}{l}1.5 \times 10^{-4} \\
3.0 \times 10^{-5} \\
1.8 \times 10^{-10}\end{array}$ & $\begin{array}{l}2.3 \times 10^{-4} \\
6.5 \times 10^{-5} \\
5.5 \times 10^{-7}\end{array}$ & $\begin{array}{l}2.9 \times 10^{-4} \\
1.1 \times 10^{-4} \\
1.6 \times 10^{-6}\end{array}$ \\
\hline \multicolumn{4}{|l|}{ katl Transport } \\
\hline $\begin{array}{l}\text { Spent Fuel } \\
\text { Normal-public } \\
\text { ioma } \text { - occupational } \\
\text { Accident - public }\end{array}$ & $\begin{array}{l}2.3 \times 10^{-3} \\
4.2 \times 10^{-7} \\
2.3 \times 10^{-9}\end{array}$ & $\begin{array}{l}2.3 \times 10^{-3} \\
4.2 \times 10^{-7} \\
6.6 \times 10^{-6}\end{array}$ & $\begin{array}{l}2.3 \times 10^{-3} \\
4.2 \times 10^{-7} \\
2.6 \times 10^{-5}\end{array}$ \\
\hline
\end{tabular}

IABLE B.4. Percentage of Travel in Each Population Zone

Transport Destination/Site

To MRS:

Arid

Warm Wet

Cold Wet

From MRS to Geologic Repository:

Distant Site:

Arid

Warm Wet

Cold wet

Near Site:

Arid

Warm Wet

Cold Wet
82.6

82.6

82.6

81.2

74.7

74.7
16.4

16.4

16.4

17.6

23.9

23.9
1.0

1.0

1. 0

1.2

1.4

TABLE 8.5. Nonradtological Unit Factors for Accidents (Neuhauser et al. 1984)

\begin{tabular}{|c|c|c|c|c|}
\hline & Rural & $\begin{array}{c}\text { Truck } \\
\text { Suburban }\end{array}$ & Urban & $\begin{array}{c}\operatorname{Raj})^{(a)} \\
\text { (Al1 Zones) }\end{array}$ \\
\hline $\begin{array}{l}\text { Nonoccupational } \\
\text { fatalities } / \mathrm{km} \\
\text { injuries } / \mathrm{km}\end{array}$ & $\begin{array}{l}5.3 \times 10^{-8} \\
8.0 \times 10^{-7}\end{array}$ & $\begin{array}{l}1.3 \times 10^{-8} \\
3.8 \times 10^{-7}\end{array}$ & $\begin{array}{l}7.5 \times 10^{-9} \\
3.7 \times 10^{-9}\end{array}$ & $\begin{array}{l}1.7 \times 10^{-8} \\
3.3 \times 10^{-8}\end{array}$ \\
\hline $\begin{array}{l}\text { Occupational } \\
\text { fatalities } / \mathrm{km} \\
\text { injuries } / \mathrm{km}\end{array}$ & $\begin{array}{l}1.5 \times 10^{-8} \\
2.8 \times 10^{-8}\end{array}$ & $\begin{array}{l}3.7 \times 10^{-9} \\
1.3 \times 10^{-8}\end{array}$ & $\begin{array}{l}2.1 \times 10^{-9} \\
1.3 \times 10^{-9}\end{array}$ & $\begin{array}{l}1.4 \times 10^{-9} \\
1.9 \times 10^{-7}\end{array}$ \\
\hline
\end{tabular}

(a) Based on railcar kilometers.

The total distance travelea per year by all shipments (cask kilometers) and number of shipments for each site are presented in Table B.6. This data is consistent with the conceptual design capacities presented in Section 2.0 of this ED and the reference site descriptions in Section 3.0 . 
TABLE B.6. Total Transportation Dístances

Destination/Mode

To MRS: $\begin{aligned} & \text { Truck(a) } \\ & \operatorname{Ra} i\rceil\end{aligned}$

To Distant Repository: Truck

Rail

To Near Repository:

Truck

Rà i
Total D

$4.5 \times 10^{6}$

$8.5 \times 10^{5}$

$7.8 \times 10^{6}$

$1.3 \times 10^{6}$

$3.9 \times 10^{5}$

$6.3 \times 10^{4}$

Warth Wet

$2.6 \times 10_{5}^{6}$

$4.8 \times 10^{5}$

$7.8 \times 10^{6}$

$1.3 \times 10^{6}$

$3.9 \times 10^{5}$

$6.3 \times 10^{4}$

cold wet

$2.2 \times 10_{5}^{6}$

$4.3 \times 10^{5}$

$7.8 \times 10^{6}$
$1.3 \times 10^{6}$

$3.9 \times 10^{5}$
$6.3 \times 10^{4}$

(a) Truck transpurt for 2 PWh or 5 BWR assemblies per shipment.

(b) Rail transport for 12 PWR or 32 BWR assemblies per shipineit.

\section{B.4 DECOMMISSIONING}

Deconmissioning will be performed after ali stored waste has been removed from the site. Residual contamination will be minimal due to frequent decontamination performed during the operation period. The cask/drywell monitoring system will also warn of potential leakage and dilow correction of situations that would otherwise result in residual contamination (i.e., from leaking casks/drywells). Because of these reasons, no significant radiological impacts on the public could be identified.

\section{B.5 ATMOSPHER.IC TRANSPORT ESTIMAIES}

Calculation of offsite radiological consequences and cuncentrations of nonradiological materials requires an estimate of atmospheric transport from the release point to various locations nearby. Fur releases under normal operating conditions, which are approxinately continuous over the year, dispersion factors are calculated ds annua T averages using the coniputer program X0000Q (Sagendorf et al. 1982). The program is based on a straight-line trajectory Gaussian plume model with crosswind averaging for 16 sectors of $222^{\circ}$ each. This program was used to estimate annual average nonmalizeo oispersion factors ( $\left.\vec{A} / Q^{\prime}\right)$ as a function of distance and direction from the release point, based on site-specific juint frequency data for wind speed, wind direction, and atmospheric stability. These data were used in the $X 0000 Q$ progran to generate $X / Q^{\prime}$ tables for ground-level releases at each site. The calculated $X / Q^{\prime}$ values are presented in Table B.7 for the arid site; Tables B.8 for the warm-wet site; and Table B.9 for the cold-wet site.

The $\bar{X} / Q^{\prime}$ values are coupled with the population distributions to give a population dispersion factur for the site. This dispersion factor is then used in all population dose caiculations for a site. The population dispersion factor is calculated for a site as follows:

$$
P M=\sum_{i=1}^{\text {distance }} \sum_{j=1}^{\text {direction }}\left(\bar{X} / Q^{\prime}\right)_{i j} P_{i j}
$$

where

$P M$ is the population dispersion factor for the site, person $\mathrm{sec} / \mathrm{m}^{3}$;

$\left(\bar{X} / Q^{\prime}\right)_{j j}$ is the annual average dispersion factor for distance $i$ in sector $j$, sec $/ \mathrm{m}^{3}$; and

$P_{i j}$ is the number of people residing in the ared interval at distance $j$ in sector $j$, persons.

A sumary of the calculated population dispersion factors is presented in Table B.10.

The annual average dispersion factor for the maximally exposed individual is taken from the $X / Q$ ' tables as the highest value corresponding to area intervals where people may reside. For all three reference sites, the nearest individual is assumed to reside in the 3- to 5-km (2- to 3-mile) interval. These $X / Q^{\prime}$ values are used in estimating annual average concentrations for nonradiolugical emissions. $A$ sumary of $X / Q^{\prime}$ values for the maxisum individual is given in Table $B .11$. 
TABLE B.7. Arid Site Annual Average Uispersion Factors ( $\mathrm{sec} / \mathrm{m}^{3}$ ) for Ground-Level Releases

\begin{tabular}{|c|c|c|c|c|c|c|c|c|c|c|}
\hline \multirow{2}{*}{$\begin{array}{l}\text { Dowllwind } \\
\text { Sector }\end{array}$} & \multicolumn{10}{|c|}{ Distance Interval, nijles } \\
\hline & $0-1$ & $1-2$ & $2+3$ & $3-4$ & $4-5$ & $5-10$ & $10-20$ & $20-30$ & $30-40$ & $40-50$ \\
\hline & $8.97 \times 10^{-6}$ & $2.85 \times 10^{-6}$ & $1.30 \times 10^{-6}$ & $.99 \times 10^{-7}$ & $5.63 \times 10^{-7}$ & $2.89 \times 10^{-7}$ & $1.17 \times 10^{-7}$ & $6.09 \times 10^{-8}$ & $4.01 \times 10^{-8}$ & $2.94 \times 10^{-8}$ \\
\hline NE & $7.27 \times 10^{-6}$ & 6 & $07-6$ & $c^{-7}$ & $4.71 \times 10^{-7}$ & $2.44 \times 10^{-7}$ & $1.00 \times 10^{-7}$ & $5.24 \times 10^{-8}$ & $3.46 \times 10^{-8}$ & $2.55 \times 10^{-8}$ \\
\hline VE & $6.83 \times 10^{-6}$ & $2.19 \times 10^{-6}$ & $1.01 \times 10^{-6}$ & $6.30 \times 10^{-7}$ & $.48 \times 10^{-7}$ & $2.33 \times 10^{-7}$ & $9.61 \times 10^{-8}$ & $5.06 \times 10^{-8}$ & $3.35 \times 10^{-8}$ & $2.47 \times 10^{-8}$ \\
\hline ENE & $7.40 \times 10^{-6}$ & $2.37 \times 10^{-6}$ & $1.09 \times 10^{-6}$ & $5.80 \times 10^{-7}$ & $4.83 \times 10^{-7}$ & $2.50 \times 10^{-7}$ & $1.03 \times 10^{-7}$ & $5.43 \times 10^{-8}$ & $3.59 \times 10^{-8}$ & $2.65 \times 10^{-8}$ \\
\hline & $9.84 \times 10^{-6}$ & $3.13 \times 10^{-6}$ & $1.44 \times 10^{-6}$ & $8.92 \times 10^{-7}$ & $6.32 \times 10^{-7}$ & $3.26 \times 10^{-7}$ & $1.34 \times 10^{-7}$ & $7.05 \times 10^{-8}$ & $4.67 \times 10^{-8}$ & $3.44 \times 10^{-8}$ \\
\hline $\mathrm{E}$ & $9.45 \times 10^{-6}$ & $3.02 \times 10^{-6}$ & $1.39 \times 10^{-6}$ & $8.69 \times 10^{-7}$ & $6.17 \times 10^{-7}$ & $3.20 \times 10^{-7}$ & $1.32 \times 10^{-7}$ & $6.96 \times 10^{-8}$ & $4.62 \times 10^{-8}$ & $3.41 \times 10^{-8}$ \\
\hline & $7.43 \times 10^{-6}$ & $3.01 \times 10^{-6}$ & $1.39 \times 10^{-6}$ & $8.64 \times 10^{-7}$ & $6.13 \times 10^{-7}$ & $3.18 \times 10^{-7}$ & $1.31 \times 10^{-7}$ & $6.92 \times 10^{-8}$ & $4.59 \times 10^{-8}$ & $3.39 \times 10^{-8}$ \\
\hline SSE & $7.45 \times 10^{-6}$ & $2.39 \times 10^{-6}$ & $1.10 \times 10$ & $6.86 \times 10^{-7}$ & $4.88 \times 10^{-7}$ & $2.53 \times 10^{-7}$ & $1.05 \times 10^{-7}$ & $5.50 \times 10^{-8}$ & $3.64 \times 10^{-8}$ & $2.69 \times 10^{-8}$ \\
\hline & $9.38 \times 10^{-6}$ & 209x & $36 \times 10^{-6}$ & $8.41 \times 10^{-7}$ & $5.94 \times 10^{-7}$ & $3.07 \times 10^{-7}$ & $1.26 \times 10^{-7}$ & $6.61 \times 10^{-8}$ & $4.38 \times 10^{-8}$ & $3.23 \times 10^{-8}$ \\
\hline $55 \mathrm{~W}$ & $4.58 \times 10^{-6}$ & $1.45 \times 10^{-6}$ & $6.59 \times 10^{-7}$ & $4.06 \times 10^{-7}$ & $2.87 \times 10^{-7}$ & $1.47 \times 10^{-7}$ & $6.00 \times 10^{-8}$ & $3.13 \times 10^{-8}$ & $2.06 \times 10^{-8}$ & $1.52 \times 10^{-8}$ \\
\hline & $1.91 \times 10^{-6}$ & $5.95 \times 10^{-7}$ & $2.64 \times 10^{-7}$ & $1.61 \times 10^{-7}$ & $1.12 \times 10^{-7}$ & $5.70 \times 10^{-8}$ & $2.29 \times 10^{-8}$ & $1.19 \times 10^{-8}$ & $7.78 \times 10^{-9}$ & $5.70 \times 10^{-9}$ \\
\hline WSW & $7.18 \times 10^{-6}$ & $2.28 \times 10^{-6}$ & $1.04 \times 10^{-6}$ & $6.48 \times 10^{-7}$ & $4.59 \times 10^{-7}$ & $2.38 \times 10^{-7}$ & $9.79 \times 10^{-8}$ & $5.16 \times 10^{-8}$ & $3.42 \times 10^{-8}$ & $2.53 \times 10^{-8}$ \\
\hline & $2.51 \times 10^{-6}$ & $7.80 \times 10^{-7}$ & $3.50 \times 10^{-7}$ & $2.15 \times 10^{-7}$ & $1.51 \times 10^{-7}$ & $7.78 \times 10^{-8}$ & $3.20 \times 10^{-8}$ & $1.68 \times 10^{-8}$ & $1.12 \times 10^{-8}$ & $8.25 \times 10^{-9}$ \\
\hline NW & $6.33 \times 10^{-6}$ & $2.02 \times 10^{-6}$ & $9.33 \times 10^{-7}$ & $5.81 \times 10^{-7}$ & $4.13 \times 10^{-7}$ & $2.15 \times 10^{-7}$ & $8.87 \times 10^{-8}$ & $4.68 \times 10^{-8}$ & $3.10 \times 10^{-8}$ & $2.29 \times 10^{-8}$ \\
\hline NW & $4.51 \times 10^{-6}$ & $1.42 \times 10^{-6}$ & $6.48 \times 10^{-7}$ & $4.00 \times 10^{-7}$ & $2.83 \times 10^{-7}$ & $1.46 \times 10^{-7}$ & $5.97 \times 10^{-8}$ & $3.14 \times 10^{-8}$ & $2.07 \times 10^{-8}$ & $1.53 \times 10^{-8}$ \\
\hline NWW & $4.77 \times 10^{-6}$ & $1.51 \times 10^{-6}$ & $6.79 \times 10^{-7}$ & $4.16 \times 10^{-7}$ & $2.92 \times 10^{-7}$ & $1.49 \times 10^{-7}$ & $5.97 \times 10^{-8}$ & $3.08 \times 10^{-8}$ & $2.02 \times 10^{-8}$ & 1. $48 \times 10^{-8}$ \\
\hline
\end{tabular}

Note: $N=$ north,$E=$ edst, $5=50 u t h$, and $W=$ west. 
IABLE B.8. Wanm-Wet Site Annual Average Dispersion Factors $\left(\mathrm{sec} / \mathrm{m}^{3}\right)$ for Ground-Level Releases

\begin{tabular}{|c|c|c|c|c|c|c|c|c|c|c|}
\hline \multirow{2}{*}{$\begin{array}{l}\text { Downwind } \\
\text { Sectur }\end{array}$} & \multicolumn{10}{|c|}{ istance Interval, miles } \\
\hline & $0-1$ & $1-2$ & $2-3$ & $3-4$ & $4-5$ & $-5-10$ & $10-20$ & $20-30$ & $30-40$ & $40-50$ \\
\hline N & $2.32 \times 10^{-6}$ & $7.39 \times 10^{-7}$ & $3.32 \times 10^{-7}$ & $2.03 \times 10^{-7}$ & $1.41 \times 10^{-7}$ & $7.10 \times 10^{-8}$ & $2.77 \times 10^{-8}$ & $1.39 \times 10^{-8}$ & $8.97 \times 10^{-9}$ & $6.48 \times 10^{-9}$ \\
\hline NNE & $2.04 \times 10^{-6}$ & $6.51 \times 10^{-7}$ & $2.92 \times 10^{-7}$ & $1.77 \times 10^{-7}$ & $1.24 \times 10^{-7}$ & $6.19 \times 10^{-8}$ & $2.41 \times 10^{-8}$ & $1.21 \times 10^{-8}$ & $7.75 \times 10^{-9}$ & $5.58 \times 10^{-9}$ \\
\hline NE & $3.07 \times 10^{-6}$ & $9.79 \times 10^{-7}$ & $4.43 \times 10^{-7}$ & $2.72 \times 10^{-7}$ & $1.91 \times 10^{-7}$ & $9.65 \times 10^{-8}$ & $3.83 \times 10^{-8}$ & $1.95 \times 10^{-8}$ & $1.27 \times 10^{-8}$ & $9.22 \times 10^{-9}$ \\
\hline ENE & $3.31 \times 10^{-6}$ & $05 \times 10^{-6}$ & $177 \times 10^{-7}$ & $2.93 \times 10^{-7}$ & $2.05 \times 10^{-7}$ & $1.04 \times 10^{-7}$ & $4.13 \times 10^{-8}$ & $2.10 \times 10^{-8}$ & $1.37 \times 10^{-8}$ & $9.93 \times 10^{-9}$ \\
\hline$E$ & $2.50 \times 10^{-6}$ & $7.94 \times 10^{-7}$ & $3.59 \times 10^{-7}$ & $2.20 \times 10^{-7}$ & $1.54 \times 10^{-7}$ & $7.81 \times 10^{-8}$ & $3.10 \times 10^{-8}$ & $1.58 \times 10^{-8}$ & $1.03 \times 10^{-8}$ & $7.45 \times 10^{-9}$ \\
\hline ESE & $2.52 \times 10^{-6}$ & $8.04 \times 10^{-7}$ & $3.66 \times 10^{-7}$ & $2.25 \times 10^{-7}$ & $1.59 \times 10^{-7}$ & $8.07 \times 10^{-8}$ & $3.23 \times 10^{-8}$ & $1.66 \times 10^{-8}$ & $1.08 \times 10^{-8}$ & $7.91 \times 10^{-9}$ \\
\hline SE & $2.23 \times 10^{-6}$ & $7.09 \times 10^{-7}$ & $3.21 \times 10^{-7}$ & $1.97 \times 10^{-7}$ & 1. $38 \times 10^{-7}$ & $7.02 \times 10^{-8}$ & $2.79 \times 10^{-8}$ & $1.42 \times 10^{-8}$ & $9.25 \times 10^{-9}$ & $6.73 \times 10^{-9}$ \\
\hline SSE & $1.52 \times 10^{-6}$ & $4.83 \times 10^{-7}$ & $2.19 \times 10^{-7}$ & $1.34 \times 10^{-7}$ & $9.40 \times 10^{-8}$ & $4.76 \times 10^{-8}$ & $1.89 \times 10^{-8}$ & $9.61 \times 10^{-9}$ & $6.24 \times 10^{-9}$ & $4.53 \times 10^{-9}$ \\
\hline & $1.60 \times 10^{-6}$ & $5.10 \times 10^{-7}$ & $2.29 \times 10^{-7}$ & $1.40 \times 10^{-7}$ & $9.77 \times 10^{-8}$ & $4.91 \times 10^{-8}$ & $1.92 \times 10^{-8}$ & $9.71 \times 10^{-9}$ & $6.27 \times 10^{-9}$ & $4.54 \times 10^{-9}$ \\
\hline SSW & $2.61 \times 10^{-6}$ & 8. $32 \times 10^{-7}$ & $3.78 \times 10^{-7}$ & $2.33 \times 10^{-7}$ & $1.64 \times 10^{-7}$ & $8.33 \times 10^{-8}$ & $3.34 \times 10^{-8}$ & $1.71 \times 10^{-8}$ & $1.12 \times 10^{-8}$ & $8.16 \times 10^{-9}$ \\
\hline SW & $2.73 \times 10^{-6}$ & $8.69 \times 10^{-7}$ & $0-7$ & $2.40 \times 10^{-7}$ & $1.68 \times 10^{-7}$ & $8.47 \times 10^{-8}$ & $3.35 \times 10^{-8}$ & $1.70 \times 10^{-8}$ & $1.10 \times 10^{-8}$ & $7.99 \times 10^{-9}$ \\
\hline WSW & $1.65 \times 10^{-6}$ & $5.23 \times 10^{-7}$ & $2.34 \times 10^{-7}$ & $1.42 \times 10^{-7}$ & $9.88 \times 10^{-8}$ & $4.93 \times 10^{-8}$ & $1.91 \times 10^{-8}$ & $9.56 \times 10^{-9}$ & 6. $13 \times 10^{-9}$ & $4.42 \times 10^{-9}$ \\
\hline & $1.57 \times 10^{-6}$ & $4.99 \times 10^{-7}$ & $2.24 \times 10^{-7}$ & $1.37 \times 10^{-7}$ & $9.55 \times 10^{-8}$ & $4.79 \times 10^{-8}$ & $1.88 \times 10^{-8}$ & $9.47 \times 10^{-9}$ & $6.11 \times 10^{-9}$ & $4.42 \times 10^{-9}$ \\
\hline WNW & $1.46 \times 10^{-6}$ & $4.65 \times 10^{-7}$ & $2.08 \times 10^{-7}$ & $1.27 \times 10^{-7}$ & $8.85 \times 10^{-8}$ & $4.43 \times 10^{-8}$ & $1.73 \times 10^{-8}$ & $8.69 \times 10^{-9}$ & $5.59 \times 10^{-9}$ & $4.04 \times 10^{-9}$ \\
\hline NW & $1.68 \times 10^{-6}$ & $5.35 \times 10^{-7}$ & $2.39 \times 10^{-7}$ & $1.45 \times 10^{-7}$ & $1.01 \times 10^{-7}$ & $5.01 \times 10^{-8}$ & $1.94 \times 10^{-8}$ & $9.63 \times 10^{-9}$ & $6.15 \times 10^{-9}$ & $4.42 \times 10^{-9}$ \\
\hline NNW & $1.76 \times 10^{-6}$ & $5.60 \times 10^{-7}$ & $2.50 \times 10^{-7}$ & $1.52 \times 10^{-7}$ & $1.06 \times 10^{-7}$ & $5.26 \times 10^{-8}$ & $2.03 \times 10^{-8}$ & $1.01 \times 10^{-8}$ & $6.44 \times 10^{-9}$ & $4.63 \times 10^{-9}$ \\
\hline
\end{tabular}

Note: $N=$ north, $E=$ edst, $S=$ south, ara $W=$ west. 
IABLE B.9. Cold-Wet Site Annual Average Oispersion Factors $\left(\mathrm{sec} / \mathrm{m}^{3}\right.$ ) for Ground-Level Releases

\begin{tabular}{|c|c|c|c|c|c|c|c|c|c|c|}
\hline \multirow{2}{*}{$\begin{array}{l}\text { Downwind } \\
\text { Sector }\end{array}$} & \multicolumn{10}{|c|}{ Distance Interval, miles } \\
\hline & $0-1$ & $1-2$ & $2-3$ & $3-4$ & $4-5$ & $5-10$ & $10-20$ & $20-30$ & $30-40$ & $40-50$ \\
\hline $\mathbf{N}$ & $3.26 \times 10^{-6}$ & $1.04 \times 10^{-6}$ & $4.66 \times 10^{-7}$ & $2.85 \times 10^{-7}$ & $1.99 \times 10^{-7}$ & $1.00 \times 10^{-7}$ & $3.95 \times 10^{-8}$ & $2.01 \times 10^{-8}$ & $1.30 \times 10^{-8}$ & $9.45 \times 10^{-9}$ \\
\hline NRE & $1.92 \times 10^{-6}$ & $6.08 \times 10^{-7}$ & $2.69 \times 10^{-7}$ & $1.62 \times 10^{-7}$ & $1.12 \times 10^{-7}$ & $5.50 \times 10^{-8}$ & $2.09 \times 10^{-8}$ & $1.03 \times 10^{-8}$ & $6.51 \times 10^{-9}$ & $4.65 \times 10^{-9}$ \\
\hline NE & $3.34 \times 10^{-6}$ & $1.06 \times 10^{-6}$ & $4.74 \times 10^{-7}$ & $2.88 \times 10^{-7}$ & $2.00 \times 10^{-7}$ & $9.99 \times 10^{-8}$ & $3.88 \times 10^{-8}$ & $1.94 \times 10^{-8}$ & $1.25 \times 10^{-8}$ & $9.00 \times 10^{-9}$ \\
\hline ENE & $1.42 \times 10^{-6}$ & $4.48 \times 10^{-7}$ & $1.99 \times 10^{-7}$ & $1.20 \times 10^{-7}$ & $8.31 \times 10^{-8}$ & $4.11 \times 10^{-8}$ & $1.57 \times 10^{-8}$ & $7.79 \times 10^{-9}$ & $4.97 \times 10^{-9}$ & $3.57 \times 10^{-9}$ \\
\hline E & $2.74 \times 10^{-6}$ & $8.71 \times 10^{-7}$ & $3.92 \times 10^{-7}$ & $2.39 \times 10^{-7}$ & $1.67 \times 10^{-7}$ & 8. $43 \times 10^{-8}$ & $3.32 \times 10^{-8}$ & $1.68 \times 10^{-8}$ & $1.09 \times 10^{-8}$ & $7.91 \times 10^{-9}$ \\
\hline ESE & $2.86 \times 10^{-6}$ & $9.07 \times 10^{-7}$ & $4.06 \times 10^{-7}$ & $2.47 \times 10^{-7}$ & $1.73 \times 10^{-7}$ & $8.64 \times 10^{-8}$ & $3.37 \times 10^{-8}$ & $1.69 \times 10^{-8}$ & $1.09 \times 10^{-8}$ & $7.88 \times 10^{-9}$ \\
\hline SE & $3.19 \times 10^{-6}$ & $1.01 \times 10^{-6}$ & $4.56 \times 10^{-7}$ & $2.79 \times 10^{-7}$ & $1.95 \times 10^{-7}$ & $9.83 \times 10^{-8}$ & $3.88 \times 10^{-8}$ & $1.97 \times 10^{-8}$ & $1.28 \times 10^{-8}$ & $9.28 \times 10^{-9}$ \\
\hline SSE & $3.46 \times 10^{-6}$ & $1.10 \times 10^{-6}$ & $4.90 \times 10^{-7}$ & $2.98 \times 10^{-7}$ & $2.07 \times 10^{-7}$ & $1.04 \times 10^{-7}$ & $4.04 \times 10^{-8}$ & $2.03 \times 10^{-8}$ & $1.31 \times 10^{-8}$ & $9.49 \times 10^{-9}$ \\
\hline$S$ & $2.53 \times 10^{-6}$ & $8.04 \times 10^{-7}$ & $3.61 \times 10^{-7}$ & $2.20 \times 10^{-7}$ & $1.54 \times 10^{-7}$ & $7.73 \times 10^{-8}$ & $3.03 \times 10^{-8}$ & $1.53 \times 10^{-8}$ & $9.91 \times 10^{-9}$ & $7.18 \times 10^{-9}$ \\
\hline SSW & $3.71 \times 10^{-6}$ & $1.18 \times 10^{-6}$ & $5.29 \times 10^{-7}$ & $3.23 \times 10^{-7}$ & $2.25 \times 10^{-7}$ & $1.13 \times 10^{-7}$ & $4.43 \times 10^{-8}$ & $2.23 \times 10^{-8}$ & $1.44 \times 10^{-8}$ & $1.04 \times 10^{-8}$ \\
\hline SW & $3.60 \times 10^{-6}$ & $1.14 \times 10^{-6}$ & $5.13 \times 10^{-7}$ & $3.12 \times 10^{-7}$ & $2.18 \times 10^{-7}$ & $1.09 \times 10^{-7}$ & $4.27 \times 10^{-8}$ & $2.15 \times 10^{-8}$ & $1.39 \times 10^{-8}$ & $1.00 \times 10^{-8}$ \\
\hline WSH & $4.80 \times 10^{-6}$ & $1.53 \times 10^{-6}$ & $6.82 \times 10^{-7}$ & $4.15 \times 10^{-7}$ & $2.89 \times 10^{-7}$ & $1.44 \times 10^{-7}$ & $5.61 \times 10^{-8}$ & $2.81 \times 10^{-8}$ & $1.80 \times 10^{-8}$ & $1.30 \times 10^{-8}$ \\
\hline W & $2.90 \times 10^{-6}$ & $9.20 \times 10^{-7}$ & $4.11 \times 10^{-7}$ & $2.50 \times 10^{-7}$ & $1.74 \times 10^{-7}$ & $8.68 \times 10^{-8}$ & $3.37 \times 10^{-8}$ & $1.69 \times 10^{-8}$ & $1.08 \times 10^{-8}$ & $7.80 \times 10^{-9}$ \\
\hline WNW & $3.50 \times 10^{-6}$ & 1. $11 \times 10^{-6}$ & $4.95 \times 10^{-7}$ & $2.99 \times 10^{-7}$ & $2.08 \times 10^{-7}$ & $1.04 \times 10^{-7}$ & $3.99 \times 10^{-8}$ & $1.99 \times 10^{-8}$ & $1.27 \times 10^{-8}$ & $9.16 \times 10^{-9}$ \\
\hline NW & $3.06 \times 10^{-6}$ & $9.70 \times 10^{-7}$ & 4. $33 \times 10^{-7}$ & $2.62 \times 10^{-7}$ & $1.82 \times 10^{-7}$ & $9.09 \times 10^{-8}$ & $3.51 \times 10^{-8}$ & $1.75 \times 10^{-8}$ & $1.12 \times 10^{-8}$ & $8.09 \times 10^{-9}$ \\
\hline NNG & $2.82 \times 10^{-6}$ & $8.86 \times 10^{-7}$ & $3.87 \times 10^{-7}$ & $2.31 \times 10^{-7}$ & $1.58 \times 10^{-7}$ & $7.68 \times 10^{-8}$ & $2.84 \times 10^{-8}$ & $1.37 \times 10^{-8}$ & B. $57 \times 10^{-9}$ & $6.07 \times 10^{-9}$ \\
\hline
\end{tabular}

Note: $N=$ north, $E=$ east, $S=$ south, and $W=$ west. 
TABLE B.10. Summary of Population Dispersion Factors at Ground Leve?

$\begin{array}{lc}\text { Site } & \begin{array}{c}\text { Dispersion Factor } \\ \left.\text { (person-sec } / \mathrm{m}^{3}\right)\end{array} \\ \text { Arid } & 5.8 \times 10^{-3} \\ \text { Warm wet } & 6.8 \times 10^{-3} \\ \text { Cold wet } & 2.0 \times 10^{-2}\end{array}$

(a) Based on the 50-mile populations of 234,000 (arid), 623,000 (warm wet), and $1,560,000$ (cold wet).

TABLE B.11. Sumary of 0ispersion Factors for the Maximuml Individual for Routine Releases at Ground Level

\begin{tabular}{l} 
Site \\
\hline Arid \\
Harm wet \\
Cold wet
\end{tabular}

\begin{tabular}{c}
$\begin{array}{c}\text { Dispersion Factor } \\
\left(\mathrm{sec} / \mathrm{m}^{3}\right)\end{array}$ \\
\hline $\begin{array}{c}1.4 \times 10^{-6} \\
4.8 \times 10^{-} 7 \\
6.8 \times 10^{-7}\end{array}$
\end{tabular}

For postulated abnomai releases of short duration, population exposures are calculated using the same population weighted dispersion factors as for normal reledses. These factors, when applied to short-term. releases, give an estimate of the probable population exposure considering likely dispersion conditions and the local population distribution.

The maximally exposed individual for abnormal reieases is assumed to be located at the fenceline. The fenceline is 175 meters from the release point for the concrete cask storage concept and 335 meters from the release point for the drywell concept. The computer program PAVAN (Bander 1982) was used to estimate the dispersion factors in all directions (Tabie B.12). This program uses a bivariate straight-line trajectory Gaussian plume model to estimate the frequency of occurrence of dispersion factors at selected distances. The calculation is based on annual joint frequency data. The value selected for the maximum individual corresponds to the value exceeded $5 \%$ of the time for the entire site. 0ispersion factors for the $3-$ to $5-\mathrm{km}$ (2- to $3-\mathrm{mile})$ interval have been applied for all chronic, nonradiological emissions.

TABLE B.12. Dispersion Factors for the Maxinum Individual for Acute Release at Ground Leve!

Site/Fenceli
Arid
$175 \mathrm{~m}$
$335 \mathrm{~m}$
Warm wet
$175 \mathrm{~m}$
$335 \mathrm{~m}$
Cold wet
$175 \mathrm{~m}$
$335 \mathrm{~m}$

Dispersion Factor

$2.0 \times 10^{-2}$
$6.7 \times 10^{-3}$

$3.3 \times 10^{-3}$

$1.2 \times 10^{-3}$

$3.1 \times 10^{-3}$

$1.2 \times 10^{-3}$

\section{B. 6 DOSIMETRY}

This section describes the basic dosimetry models employed by the computer programs used in the radiological duse analysis. The computer progran ALLDOS was used to perform the majority of the dose 
calculations. This program used dose factors generated by other programs; external factors from SUBDOSA (Strenge et al. 1975), inhalation factors from DACRIN (Houston et a1. 1976, Strenge 1975), and ingestion factors from PABLM (Napfer et al. 1980). A sumary of each of these dose factors is provided below.

\section{External Dose Factors}

The external dose conversion factor gives the dose from gamma radiation to an individual exposed to an infinite piume of a radionuclide. The factors are nomalized to a time-integrated air concentration of one $\mathrm{C} \ddagger \cdot \mathrm{sec} / \mathrm{m}^{3}$ over the time of plume passage.

The external dose factors calculated by SUBOOSA and used by ALLDOS are representative of the average juse to the blood-forming organs that are assumed to be at a tissue depth of $5 \mathrm{~cm}$. This dose is also a good approximation for other organ doses (NCRP 1975) and is used to determine the external dose contribution to all organs.

\section{Inhalation Dose Factors}

The inhalation dose conversion factors give the dose comitment from inhalation uptake during plume passage. Like the external dose conversion factors, the inhalation factors are nornalized to the time-integrated air concentration over the uptake period. The inhalation dose factors are given for acute and chronic releases and for two dose commitment periods ( 1 year and 50 years). Generation of the current inhalation dose factors was perfomed using the computer program DACRIN. The program OACRIN employs the respiratory tract model adopted by the ICRP Task Group on Lung Dynamics (ICRP 1965; ICRP 1972). The gastronintestinal tract model and the retention model for other organs are those of the initial ICRP publication (1959).

\section{Terrestrial Dose Factors}

The dose factors for terrestrial pathways related to atmospheric releases give the accumulatea dose from continued exposure to environmental contamination. The terrestriat dose factors for airborne releases are given for both chronic and acute releases. The dose factors are nomalized to releases of one curie per year for chronic releases and to one curje for acute reieases; with wnit values for $x / Q$. The dose factors implicitly contain many of the assumptions about demography and Tifestyle required; therefore the file must be estabilished on a site-specific basis. Generation of these dose factors is perfomed using the computer program PABLM (Napier, Kennedy, and Soldat 1980).

The dose factor file used by ALLDOS contains accurulated dose factors for both an average and a maximum individual. The average parameters are multiplied by a population distribution to obtain a cullective dose by ALLDOS. Dose factors are included for one-year doses and accumulated doses from both acute and chronic releases. Factors for five organs are included: total body, bone, lung, thyroid, ario lower large intestine. The factors are calculated based on all the desired exposure pathways and summed. All dietary and recreational habit information is thus worked into the dose factors, making them site-specific.

\section{B.7 TOXICITY OF PROCESS MATERIALS}

Toxicity is defined as the ability of a chemical to cause injury once it reaches the body. The systell of toxicity rating (Sax 1984) used in this appendix is outlined in Table B.13.

TABLE B.13. Toxicity Rating Scale (Sax 1984)

\section{Rating}

$U=$ unknown

None $=$ no toxicity $(0)$

Low = slight toxicity (1)

Mod = moderate toxicity (2)

High = severe toxicity (3)
Effects

Insufficient data are available to enable a valid assessment of toxic hazard to be made

No toxic effects under any normal usage or requiring overwhelming doses to produce toxic effects

Produce changes readily reversible once the exposure ceases

Cause reversible or irreversible changes not necessarily severe enough to cause serious physicat impaiment or threaten ijfe

Exposure may cause injury of sufficient severity to threaten life or produce permanent impaiment, disfigurement or irreversible change. 
The Anerican Conference of Guvernmental Industrial Hygienists (ACGIH) has set levels of exposure to toxic chenicals at which no deleterious effect is noted. These are called Threshold Limit Values or tuvs. TLVs refer to air concentrations of a given chemical to which an individual can be repeatedly exposed 8 hours per day, 5 days per week. Because TLVs are time-weighted averages, limited over-exposures may be permitted, if compensated for by equivalent under-exposures. In some cases ceiling limits, concentrations above which one should not be exposed, are indicated. These are industrial hygiene limits rather than a relative index of hazard.

The MRS facility will be designed to meet standards of industrial safety. Table B.14 lists materials to be used in an MRS facility, along with TLV and hazard rating.

TABLE 3.14. Toxicity and TLV of Process Chemicals to be Used at an MRS Facility

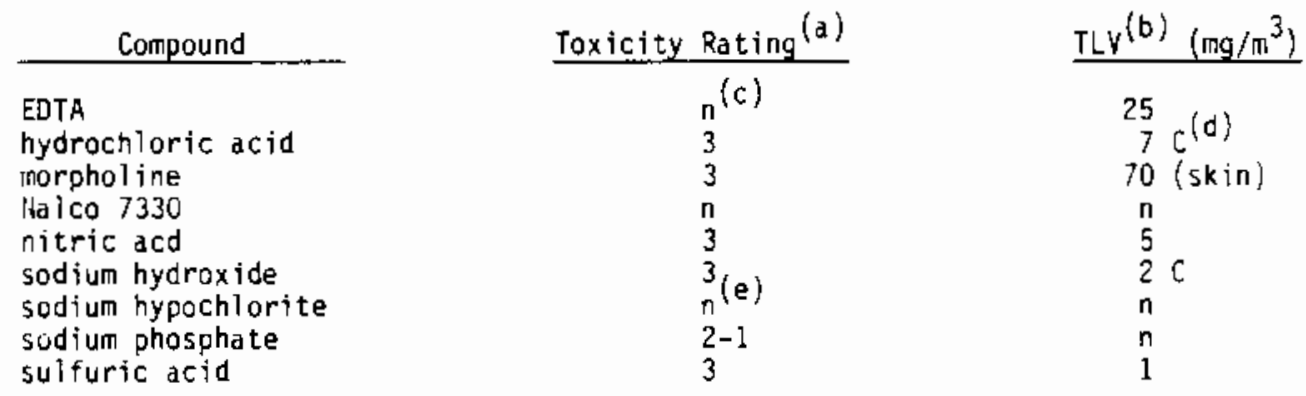
(a) Rating from Sax (1984)
(b) Threshold Limit Value (ACGIH 1983)
(c) $n$ indicates information not available
(d) C denotes ceiling limit
(e) corrosive and irritant.

\section{Q.\& REFERENCES}

American Conference of Governmental Industrial Hygienists (ACGIH). 1983. TLVs Threshold Limit Values for Chenical Substances in the Work Environment Adopted by ACGIH for 1983-1984. ISBN: $0-936712-45-7$, ACHIH, Cincinnati, ohio.

Bander, T. J. 1982. PAVAN: An Atmospheric Dispersion Program for Evaluating Design Basis Accidental Releases of Radioactive Materials from Huclear Power Stations. NJREG/CR-2858 (PNL-4413), U.5. Fiuclear Regulatory Commission, Washingtun, D.C.

Federal Register. 1984. "Proposed Revisions to the National Ambient Air Quality Standards for Particulate Matter," 49 Fed. Reg. 55:10408-30 (March 20, 1984).

Houston, J. R., D. L. Strenge and E. B. Hatson. 1976. DACRIN--A Computer Program for Calculating Organ Doses from Acute or Chronic Radionuclide Inhalation. BNWL-B-3E9, Pacific Northwest Laboratory, PichTand, Wishington.

Internatiund Commission on Radiological Protection (ICRP). 1959. Report of Committee If on Permissible Dose for Internal Radiation. ICRP Publication 2, Pergamon Press, New York.

International Commission on Radiological Protection (ICRP). I966. Deposition and Retention Models for Internal Dosimetry of the Human Respiratory Tract. Health Phys. 12:173-207.

International Commission on Radiological Protection (ICRP). 1972. The Metabolism of Compounds uf Plutunium and Other Actinides. ICRP Publication 19, Pergamon Press, New York.

Kircher, D. S. 1975. "Heavy Construction Equipment," in Compilation of Air Pollutant Emission Facturs, Third Edition (including Supplements 1-11, October 1980), pp. 3.2.7-1-3.2.7-5. U.S, Environmental Protection Agency, Kesearch Triangle Park, North Carolina.

Kircher, C. S., and M. E. hilliams. 1975. "Highway Vehicles," in Compilation of Air Pollutant Enilssion Factors. Third Edition (including Supplements 1-11, October 1980), pp. 3.1-1-3.1.5-3. i.5. Environmental Protection Agency, Research Triangle Park, North Carolina. 
Lahre, T. 1977. "Fuel 0i] Combustion," in Compitation of Air Pollutant Emission Factors, Third Edition (including Supplements I-11, 0ctober 1980), Pp. 1.3-1-1.3-5. J.S. Environmental Protection Agency, Research Triangle Park, North Carolina.

Madsen, M. M., E. L. Wilmot and J. M. Taylor. 1983. RADTRAN-II Users Guide. SAND82-2681, Sandia National Laboratories, Albuquerque, New Mexico.

Mann, C. O., and C. C. Cowherd, Jr. 1977. "Fugitive Dust Sources," in Compilation of Air Pollutant Emission Factors, Third Edition (including Suppiements 1-11, October 1980), pp. 11.2.1-1 - 11.2.4.1. U.S. Environmental Protection Agency, Research Triangle Park, North Carolina.

Napier, B. A., W. E. Kennedy, Jr., and J. K. Soldat. 1980. PABLM--A Computer Program tc Calculate Accumulated Radiation Dose from Ragionuclides in the Environment. PNL-320G, Pacific Morthwest Laboratory, Richiand, Washington.

National Council on Radiation Protection and Measurements (FCRP). 1975. Natural Eäckground Radiation in the United States. NCRP Report No. 45, Washington, D.C.

Neuhauser, K. S., J. W. Cashwell, P. C. Reardon and G. W. McNair. 1984. A Prelininary Cost and Risk Analysis for Transporting Spent Fuel and High-Level Wastes to Candioate Repository Sites. SANDE4-1795 (TTC-0506), Sandia Nationat Laboratories, Abuquerque, New Mexico.

Sagendorf, J. F., J. T. Goll and W. F. Sandusky, 1982. x0000Q: Computer Progran for the Meteorological Evaluation of Routine Effluent Releases at Nuclear Power Stations. NUREG/CR-2919 (PNL-4380), U.S. Nuclear Regulatory Comission, Washington, O.C.

Sax, N. I., ed, 1984. Dangerous Properties of Industrial Materials, Sixth edition. Van Nostrand Reinnolo Company, New York.

Strenge, D. L. 1975. DACRIN - A Computer Program for Calculating Organ Doses from Acute or Chronic Radionuclide INhalation: Rogification for Gastroincestinal Tract Dose. BikL-B-389 Supp., Pacific Northwest Laboratary, Richland, Washington.

Strenge, D. L., B. A. Napier, R. A. Peloquin and M. A. Zimerman. 1980. ALLDoS--A Computer Program for Calculation of Radiation Doses from Airborme and Waterborne Releases. PNL-3524, Pacific Northwest Laboratory, Richtand, washington.

Taylor, J. M., and S. L. Daniel. 1982. RADTRAN-II: A Revised Computer Code to Analyze Transportation of Rad foactive Material. SAND 80-1943, Sandia National Laboratories, ATbuquerque, New Mexico.

Transportation Technology Center (TTC). 1984. Nuclear Materials Transportation Appendix. SAND84-0062 (TTC-0471), Sandia National Laboratories, Aibuquerque, New Mexico.

U.S. Nuclear Regulatory Comission (NRC). 1979. Atmospheric Dispersion Models for Potential Accident Consequence Assessments at Nuclear Power Plants. Regulatory Guige 1.145, Washington, U.C.

Wilmot, E. L., M. M. Madsen and U. W. Cashwell. 1983. A Preliminary Analysis of the Cost and kisk of Transporting Nuclear Waste to Potentia] Candigate Comercial Repository 5ites, 5AND83-0867 (TTC-0434), Sandia lational Laboratories, Albuquerque, New Mexico. 
APPENDIX C

$+$

SOCIOECONOMIC MODELS AND ASSUMPTIONS 
. 
C.1 METHODOLOGY

C.1.1 General Procedures

C.l.2 Metropolitan and State Ėconomic Regions (MASTER) Modei

C.i.3 City/County Allocation Mode] (CCAM)

C.1.4 Fiscal Impact (FI) Model

C.2 ECONOMIC INPUT ASSUMPTIONS

C.2.i Socioeconomic Scenarios:

C.2.2 Socioeconomic Scenarios:

C.3 VALIOATION

C.4 REFERENCES

\section{TABLES}

C.I MASTER Forecast Outputs

C.2 List of Variables Forecasted by CCAM

C.3 Growth in the Reference-Site Economies and Population without MRS

C. 4 Direct Employment and Expenditure Estimates for an MRS Facility

C.5 Mean Absoiute Percent Error of Out-of-Sample Forecast, 1976-1980

C.6 Vajidation Test Forecast Results of the MASTER Hodel Versus Actual Values for key Variables, Richland-Kennewick-Pasco Metropolitan Statistical Area, 1976-1981

\section{FIGURES}

C.1 The MRS Socioeconomic Impact Assessment Process for a Reference Site.

C. 2 MASTER Model: Simple Model Schematic

C. 3 Simple Schematic of CCAM Model

C.4 Directions and Distances of Population Produced by the CCAM Model Code

C.5 Simple Schematic of the FI Model 
The methodologies used for projecting the socioeconomic impact of an MRS facility at three alternative reference sites are described in this appendix. The backup MRS facility, if built, is currently expected to be constructed between 1992 and 1997 and would operate for about 25 years of its 40-year 1 icensed iife. Because the facility would actually be built and operated several years from now, a projection of socioeconomic conditions for both baseline (without the MRS facility) and impact (with the MRS facility) scenarios was required in order to estimate future quantitative socioeconomic impacts of the facility. Baseline projections for the reference sites were made using computer codes designed for economic, demographic, and comunity impact forecasting. The forecasted growth path of the economy at each reference site was then changed by adding to it the construction, operation, and decommissioning activities at the site. This change is translated by the modei into estimates of additional regional employment, papulaticn, housing and other community service requirements, and impacts on receipts and expenditures of the state, county and city governments and school districts in the vicinity of the site for each future year. Dochmentation on the computer codes is avaliable from other sources.

\section{C.1 METHODOLOGY}

This section describes the methodology used in the ED to estimate socioeconomic impacts of the MRS facility. The discussion is divided into an overview of the estimation process and description of each of the three linked computer codes that perform the computations to estimate economic impacts, demiographic and community services impacts, and local government fiscal impacts. The general procedures are described below and illustrated in Figure C.1.

\section{C.1.I General Procedures}

First, benchmark socioeconomic characteristics were assembled for three refurence sites. This was accomplished by reading several magnetic data tapes from the Bureau of Economic Analysis, Regional Econonic Information System, and Bureau of Census. These contained historical county-level economic, population, and local fiscal data on every county in the Inited States. Several counties in each climatic region having socioeconomic characteristics with values simitar to those in Chapter 3 for the three reference sites; these were assembled into impact areas. Each impact area consisted of a central county and a group of surrounding counties approximating a 50 -nile radius from the site. For each county, the economic, population, and community information were all assumed to be mutually consistent. The analysis was then performed as if these reference sites were real sites.

The remainder of the analysis was conducted as follows. The benchmark site characteristics of each reference site were entered into a computer data base for a "central county" and a "noncentral county" at each site. (a) We selected a moderate economic growth scenario for the United States based on recent longterm economic forecasts by Data Resources, Incorporated. The appropriate regional subroutine for the econonetric model (described in Section C.1.2) was run using this national forecast and the "county" benchmark data base for each "county" at each site. This yielded six baseline economic forecasts--a "central" and "noncentral" forecast for each site. No attempt was made to customize the MASTER model for the site. Thus for a given course of national economic growth, the model forecasts the average response of economies in each of the three climatic regions.

Next, the six MASTER model output data files were each entered into a computer code that allocates regional population and employment geographically within the "county", according to a gravity (weighting) procedure described in Section C.1.3. This computer code is entitled the City/County Allocation Model (CCAM). Besides computing the hypothetical distribution of population around the MRS site, this code also uses regional or national standards for community services such as housing, fire and police protection, health care services, and utilities to compute estimated total requirenents for these services under baseline cunditions in each forecast year for each "county."

(a) The term "centrai county" refers to the geographical and politicat subdivision containing the MRS facility. The Nuclear Waste Policy Act treats this local government somewhat differently for impact mitigation purposes from the surrounding geographic area, which might also be affected by MRS facility construction, operation, and decomissioning. In the case of the arid site and warm-wet site, two adjoining counties were actually chosen and analyzed as a single "central county." The "noncentral" county is an aggregation of several counties surrounding the central county. If the majority of a given county's people would be located within 50 miles of the MRS facility, the county was included; if not, the cuunty was excluded from the noncentral county. 


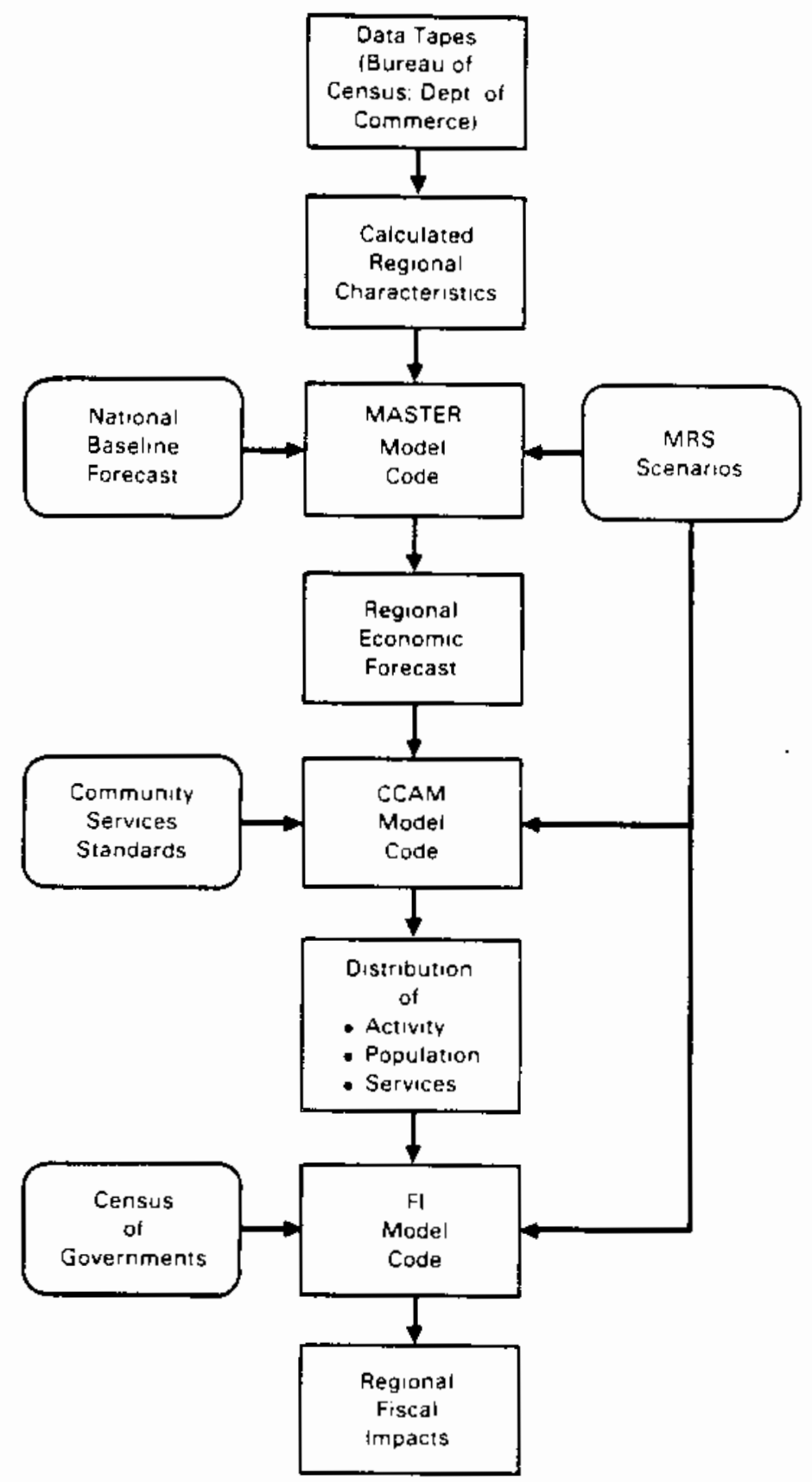

FIGURE C.1. The MRS Socioeconomic Impact Assessment Process for a Reference Site

Findily, the six MASTER model output data files were entered into a computer code that forecasts state and local government revenues, expenditures, fiscal balances, and items such as outstanding bonded debt. In general, these fiscal items depend on the tax base and community expenditure standards for real sites; however, fur reference sites we used representative per capita revenue and expenditure numbers from the 1977 Census of Government. The computer code, known as the Fiscal impact (FI) model, thus produced baseline estimates of state and local fiscal items for the central and noncentral counties at each site as if the local government entities involved continued to receive and expend funds at inflation-adjusted rates comparable to those in effect at the last Census of Government. The FI model is described in Section C.1.4.

Next, the entire forecasting procedure outlined above was repeated for two sets of impact conditions. In the first impact case, economic activity related to a staled storage cask MRS facility was added to the baseline MASTER model input and the six forecasts recalculated through all three computer codes. In the second case, a field drywell facility was introduced and the forecasts recalculated. The impacts of the 
sealed storage cask and field drywell MRS facilities were then estimated as the difference between the predicted values of economic and other variables in the seated storage cask case versus the baseline forecast, or as the difference between the field drywell and baseline. The discussion of each computer code follows.

\section{C.1.2 Metropolitan and State Economic Regions (MASTER) Model}

The Metropolitan and State Economic Regions (MASTER) Model is a computer code Jesigned for (I) forecasting economic activity in substate geographic areas, and (2) planning and policymaking in energy-related fields. MASTER forecasts economic activity in al1 268 metropolitan statistical areas (MSAs) recognized by the Bureau of Census, plus 48 rest-uf-state areas (ROSAs) that make up the remainder of the 48 contiguous states and the District of Columba. MASTER Version 1.0 (Adams, Moe and Scott 1983) was used in the MRS analysis. Version 1.9 consists of four submodels, one for each U.S. Census Region (Northeast, North Central, west, South) ${ }^{2}$. Each submodel can be used to forecast annual econonic activity in any MSA or ROSA in the corresponding census region. Each submodel contajis 53 stochastic equations linked together by more than 100 definitional or accounting identity equations. MASTER is an econometric mooe?; the stochastic equations were estimated statistically using time-series/cross-section multiple regression techniques suggested by Kmenta (1971) on pooled time-series/cross-section of econumic and demographic ata for the years 1967-1976 for each MSA/ROSA in the corresponding census region. The endogenous or depencent variabies forecasted by MASTER for any MSA/ROSA are shown in Table C.1.

The functionat forms and variables used in the MASTER moael equations were selected primarily according to their consistency with economic theory, and how well the resulting equations could be applied to a wide range of local conditions. For example, the dependent variable in each employment equation is the annual percentage change in employment, because this functional form could be readily adapted to both large and small regions. When a forecast is prepared, the starting value for each dependent variable is adjusted automatically in two rounds to incorporate area-specific differences between the behavior of the depencent variable in an "average" MSA/ROSA in the census region and the actual benchmark value in the area for which the forecast is prepared.

The MASTER model can forecast for any county or aggregation of counties in the United States. This is accomplished by selecting appropriate start-up values for the model's dependent variables for the group of counties and calling the model. The model then treats the aggregation of counties as it would any MSA/ROSA and produces a forecast. This was done for this report. Startup values were selected and data sets constructed for a central county "MSA" and noncentral county "MSA" at each site.

A simple schematic diagram of MASTER is shown in Figure C.2. The MASTER forecast begins with exogenous (outside the model) forecasts of sector real (adjusted for inflation) wage rates, consumer price index, national unemployment rate, and the historical ratio of local to national wage rates. Local wage rates are calculated and fed to the employment equations, along with estimates of local real personal income, national real output by sector, and cost variables such as energy prices and interest rates. Local employment is thus determined by a mix of local and national conditions. Employment is, in turn, a key input into the model's estimate of real income (which includes wage and nonwage income by component) and population. Construction is determined by interest rates, local construction prices per square foot, and the level of employment by sector or population, as appropriate. Employment, income, construction, and pcpulation are all solved for simultaneously in each forecast year to ensure internal forecast consistency.

\section{C.1.3 City/County Allocation Mode] (CCAM)}

The City/County Allocation Model (CCAM) is a computer code that performs two functions. First, it geographically allocates employment and population growth within an MSA/ROSA region forecasted by the MASTER model. This "modified gravity fonmula" is based on an assessment of where such growth has historically taken place and where the geographic focus of new development (such as for an energy project) is within the MSA/ROSA. Second, the model uses historical state, local, and national standards to estinate additional trade volume and business establishments, additional construction, and demand for community services. Communtty services include housing, educational and health facilities, pubijc utilities, and emergency services necessary to accommodate population changes in the region. The overall process is illustrated in Figure C.3.

(a) Version 1.1, currently under development, contains nine separate submodels corresponding to the smaller nine census divisions. This version also provides for 35-industry disaggregation, rather than the 12 industries in Version 1.0.

(b) For example, local resident personal income is by definition equal to labor and proprietor income, plus property income and government monetary transfers such as Social Security payments, less employee payments for socjal insurance items, plus a residence adjustment to allow for commuters.

(c) These adjustments are equivalent to inserting dumny variables in the pooled regression and adjusting for autocorrelation (systematic time-dependent error) in the forecast. See Adams et al. (1983) for elaboration on this point. 
TABLE C.1. MASTER Forecast Outputs

Employment and Annual Hages, by Sector

Agriculture
Agricultural services, forestry, and fishing

Mining

Construction

Nondurable manufacturing

Durable manufacturing

Public utilities, transportation, and communications

Wholesale trade

Retail trade

Finance, insurance, and real estate

Services

Government.

Income, by source

Wage bill (Tabor and proprietor income)

Rent, interest, and dividends

Transfer payments

Social insurance payments

Residence adjustment.

Total personal income

Per capita income

Population, by Category

Births

Deaths

Net migration

Population, age less than 5 years

Population, age $5-13$ years

Population, age 14-17 years

Population, age $18-20$ years

Population, age 21-24 years

Population, age 25-34 years

Population, age 35-44 years

Population, age 45-64 years

Population, age $65+$ years

Population, age $18-64$ years

Construction of Hew Commercial Buildings, by Building Category

Retail/wholesale

Office

Auto repair

Warehouse

Education

Health

Public

Religious

Hote1/mote]

Miscellaneous

Commercial Construction, Additions and Alternations, by Building Category

Same as new commercial construction categories

Residential Construction, by Building Categories

Apartments, five or more units, one to three stories

Apartments, five or more units, four or more stories

Apartments, three to four units

Single family, detached

Duplexes

The computer model uses a nodified gravity procedure for allocating employment and population growth to subareas or "cities." For each year in the forecast, four indexes are created that estimate the overall "attractiveness" of a given "city" or rest-of-county area, relative to all other locations within the region forecasted by MASTER, or "county." Three of the indexes are aiways used. They are:

- "city" population, relative to "county" (region) population

- "city" employment, relative to "county" (region) eniployment

- "city" retail sảes, relative to "county" (region) retail sales. 


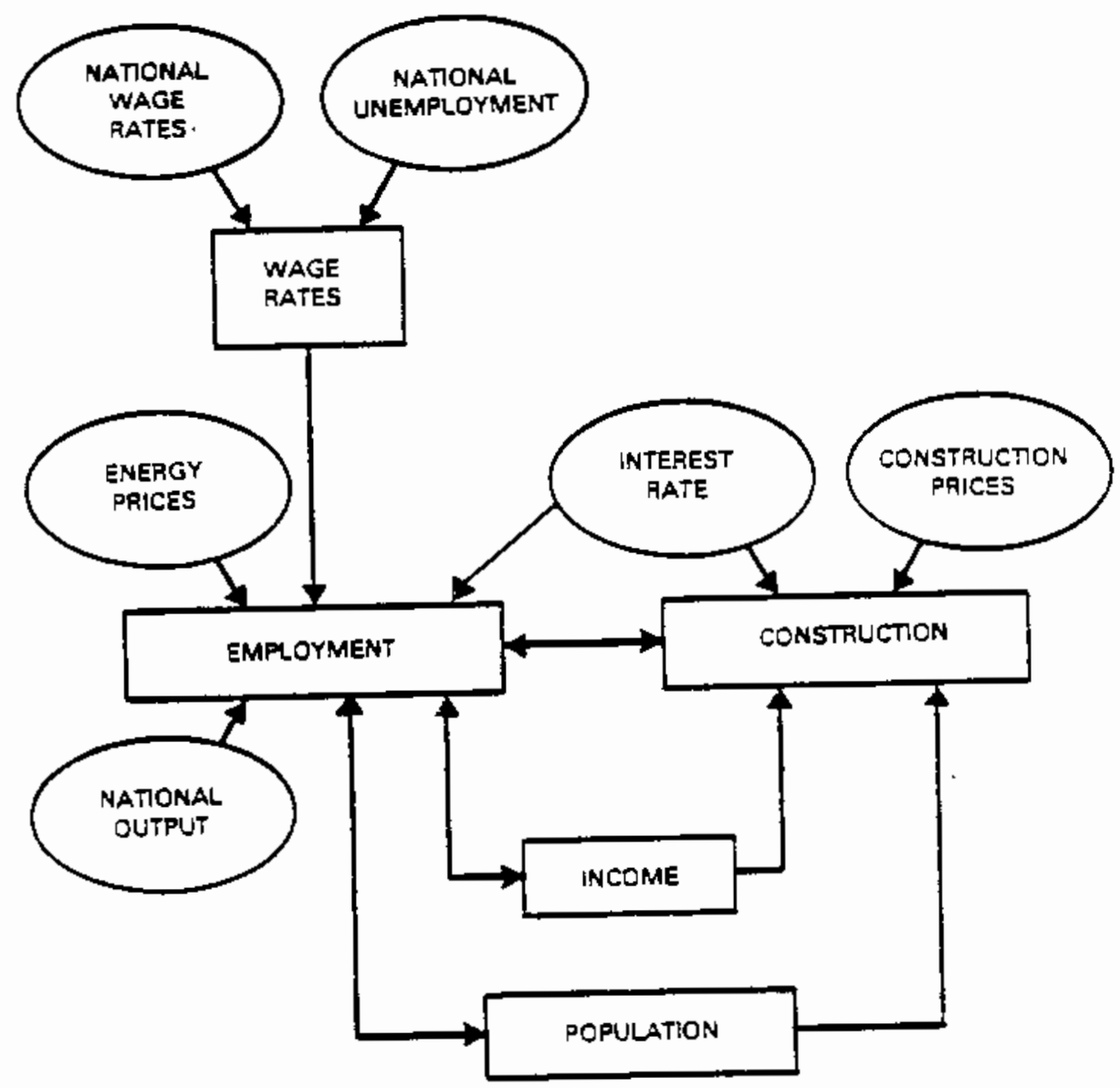

FIGURE C.2. MASTER Model: Simple Model Schematic

The attractiveness to new population or econonic activity is assumed to be proportional to existing levels cf this activity in the baseline forecast. In the impact case, two aditional factors come into play. First, a fourth allocation index is created that allocates new economic activity and population resulting from the MRS (or other) project inversely proportional to the square of the distance from the MRS site. This factor is roughly analogous to the strength of gravitation as a function of distance and so is called a "gravity" index. The strength of the gravity effects are modified by employment, population, and retail sales effects. Second, the population, empioyment, and retail sales indexes at the county level are also usEd to allocate MRS project employment between the central and noncentral countjes when the MASTER model is run for the impact case. The overali allocation factor for any city is:

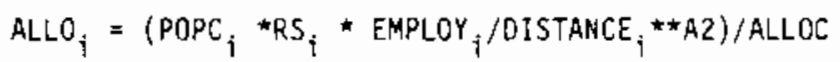

where:

$$
\begin{aligned}
& \text { ALLO }_{i}=\text { Allocation index, city } i \\
& \text { POPC }_{i}=\text { Population, city } i \\
& \text { RS }_{i}=\text { Retail sales, city } i(1985 \$) \\
& \text { EMPLOY }{ }_{i}=\text { Employment, city } i
\end{aligned}
$$

DISTANCE $_{i}=$ Distance from MRS site to the city $i$

$A 2=$ Exponent to which Distance variable is raised; currently $A 2$ is set at 2.0

$A L L O C=$ Sane form as the numerator, except that it applies to the whole county

Since each city factor is divided by its county equivalent, the entire ALLO can be viewed as the product. uf four indexes. During the forecast, ALLOC; is recalculated for each city each year for both the baseline and impact cases. 


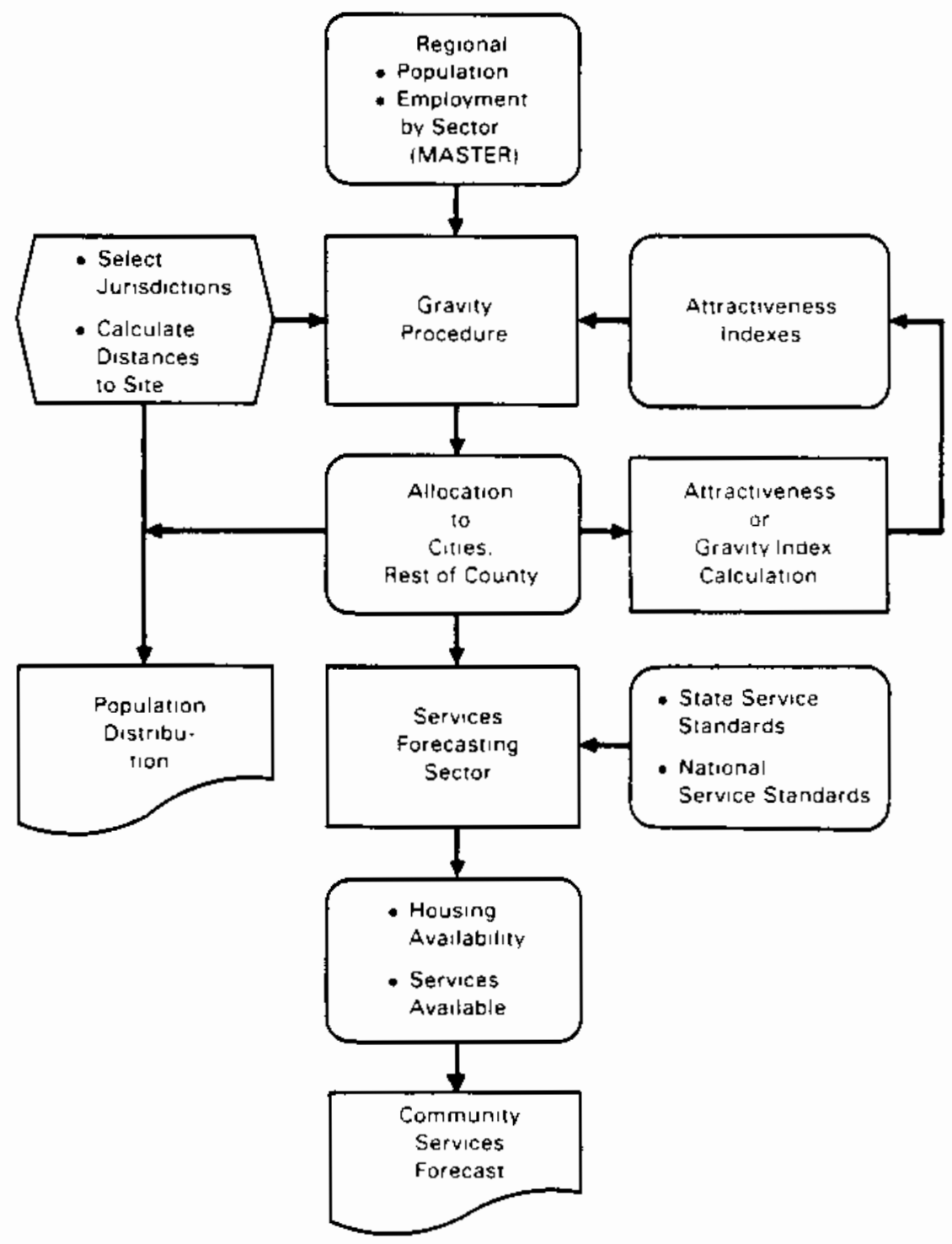

FIGURE C.3. Simple Schematic of CCAM Model

Once the population forecast has been allocated to individual cities, the ccAir code accesses a data base on the distances and direction of each "city" or rest-of-county area from the proposed liRS site. The model then calculates population distribution for concentric distance rings and directions from the site. Figure C. 4 illustrates the distances and central radii of the 16 directional segments recognized by CCAM.

Next, CCAM calculates total community service requirements for local areas. While this can be done at the city level, for the MRS ER, CCAM reports this information at the county level using best information on per capita service standards at the state or national level or (where available) existing per capita service standards for the locality. For the MRS ED, state histurical average service standards and some national standards, where these existed, were used to detenine "standard practice." Thus, the CCAri forecasts of impacts on local commuity services represent average increases of requirements for communty services, given per capita numbers of police, hospitals, acres of parks, etc. for average conmunities in the arid, cold-wet, and warm-wet regions. Table $c .2$ gives a list of comunity service requirements and other variables furecasted by CCAM.

\section{C.1.4 Fiscal Impact (FI) Model}

The Fiscal Impact (FI) Model is a computer code that estimates per capita revenues, expenditures, and other fiscal items such as the amount of bonded debt for state and local governnient entities in any geographic region for which the MASTER/CCAM models provide population forecasts. Four levels of government 


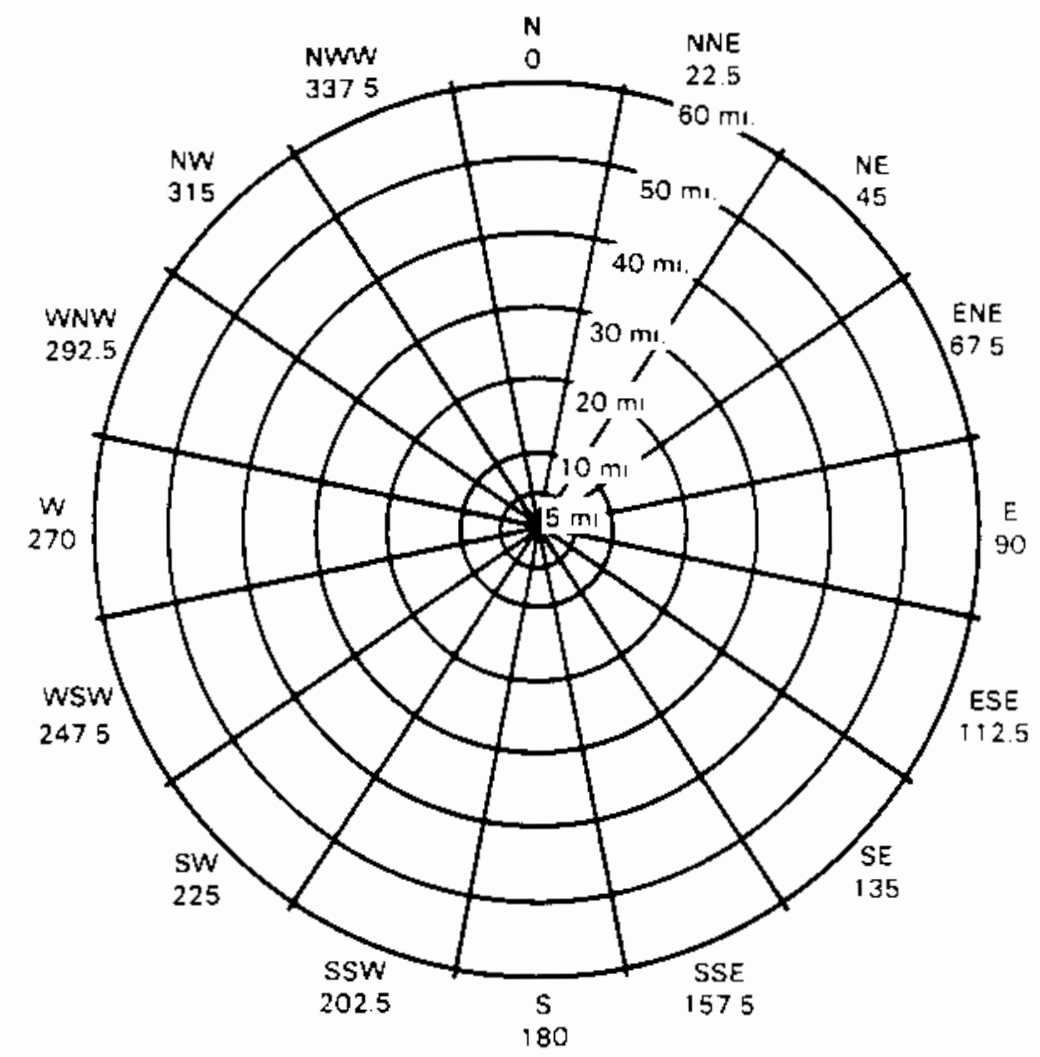

FIGURE C.4. Directions and Distances of Population Produced by the CCAM Model Code

are currently recognized: state, county, city, and independent school districts. The FI model can be used to forecast each local jurisdiction separately, or consolidated fiscal estimates for all cities, county govermments, or school districts may be provided. For the MRS ED, the consolidated forecasting option was used. The FI model forecasts 181 fiscal line items, corresponding to groups or categories of revenues (by source), expenditures (by function and type of expenditure), and balance sheet iterns recorded inl the Census of Governments. For the MRS ED, only total expenditures and revenues were reported.

Figure C.5 shows a simple schematic diagram of the FI model. Any forecast begins with a selection of the jurisdiction(s) that are to be reported in the forecast. MASTER model or CCAM population forecasts must be available for the service area(s) represented by each local jurisdiction. For each jurisdiction, the model accesses a data base containing historical total dollar amounts for the fiscal items reported by the FI model. These jurisdictions are aggregated as appropriate for the forecast (e.g., all cities within a given county might be combined), and divided by the appropriate historical population measure to obtain per capita values for the various fiscal items. For most items, this is tatal resident population; nowever, for a limited number of programs a definite age cohort user group may be identified, as in the case of primary and secondary education. In that case the user group is population aged 5-17 years. if the users have better infomation, they may override the default per capita values computed by the FI model.

The FI model next links the appropriate forecasted population totals to the per capita fiscal item totais. The model then calculates each fiscal item for each forecast year for each population forecast. The individual fiscal items are then aggregated as appropriate, and forecasts are compared to determine impacts.

\section{C.2 ECONOMIC INPUT ASSUMPTIONS}

This section discusses the MRS economic inputs and baseline assumptions used to prepare the socioeconomic impact estimates in this report. The first subsection discusses baseline conditions forecasted by MASTER/CCAM/FI for each reference site without MRS. This is followed by a discussian of the MRS project data as it was used to estimate socioeconomic impacts. 
TABLE C.2. List of Variables Forecasted by CCAM

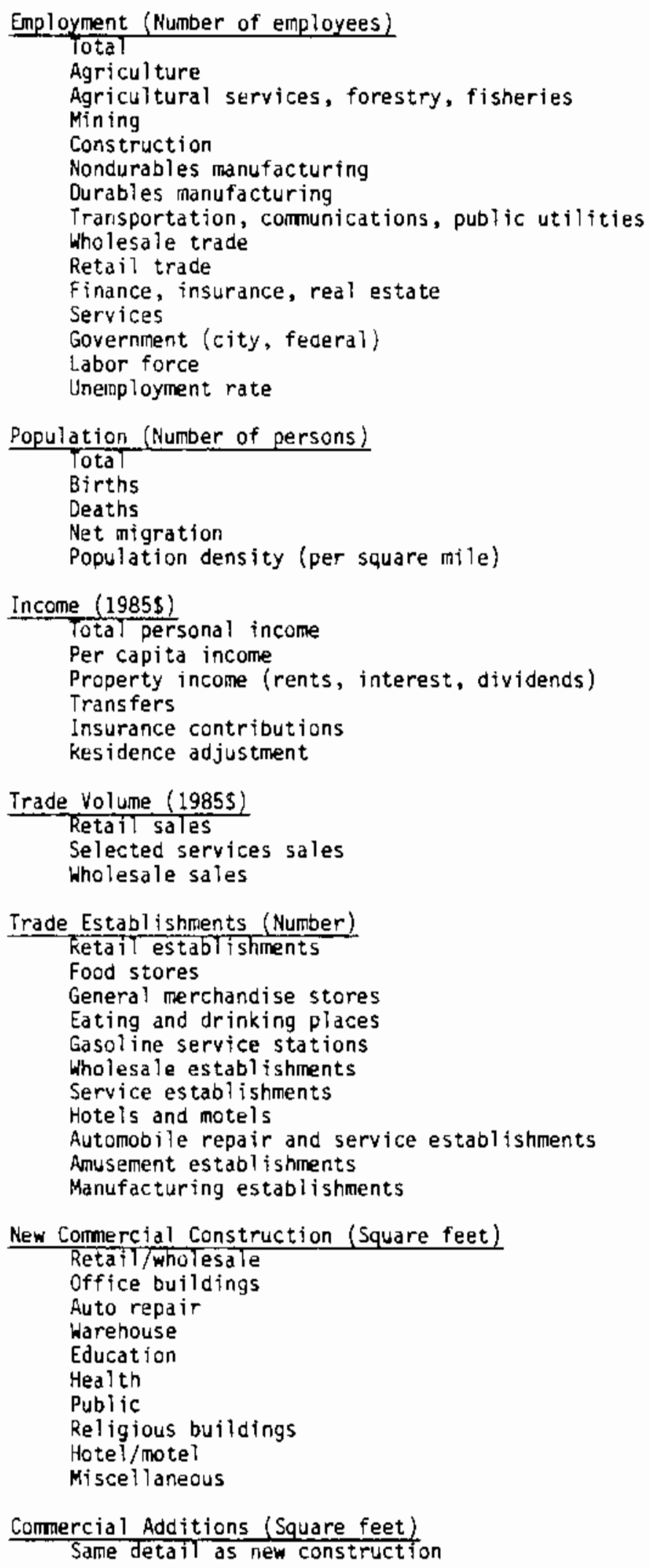


TabTe C.2 (Contd)

Residential Construction (Number of units)

Mutti-family units

Single family units

Mobile homes

Total residential units

Vacancy rate

Units rented

Housing cost indices

Education

Number of elementary schools

Number of high schools

Library staff: professional

Library staff: nonprofessional

Total Tibrary staff

Library book collection (Number of volumes)

Library collection of periodicals and records (Number of items)

Hea]th (ivumber of)

Doctors

Dentists

Nurses

Hospitals

Hospital beds

Social Services

Number of people below poverty line

Energency Services (Number of)

Fire stations

Fire protection personnel

Ambulances

Emergency medical technicians

Fire trucks

Police vehicles

Police officers

Public Utilities

Water supply (Number of feet required)

$48^{\prime \prime}$ transmission lines

$38^{\prime \prime}$ transmission lines

36 " transmission lines

$33^{\prime \prime}$ transmission lines

Interceptor sewer lines (Number of feet required)

$42^{\prime \prime}$ lines

$36^{\prime \prime}$ lines

$30^{\prime \prime}$ lines

Solid waste services: number of trucks

Solid waste stancards: number of personnel

Total natural gas consumption (therms per day)

Total electricity consumption (kWh per day)

Total electrical capacity (kwh per day)

water use, all sources (gallons per day)

Sewage, all sources (galions per day)

Corrections

Total number of crimes

Number of persons under correctional supervision

In jail

In prison

Parole

Probation 
Table C.2 (Contd)
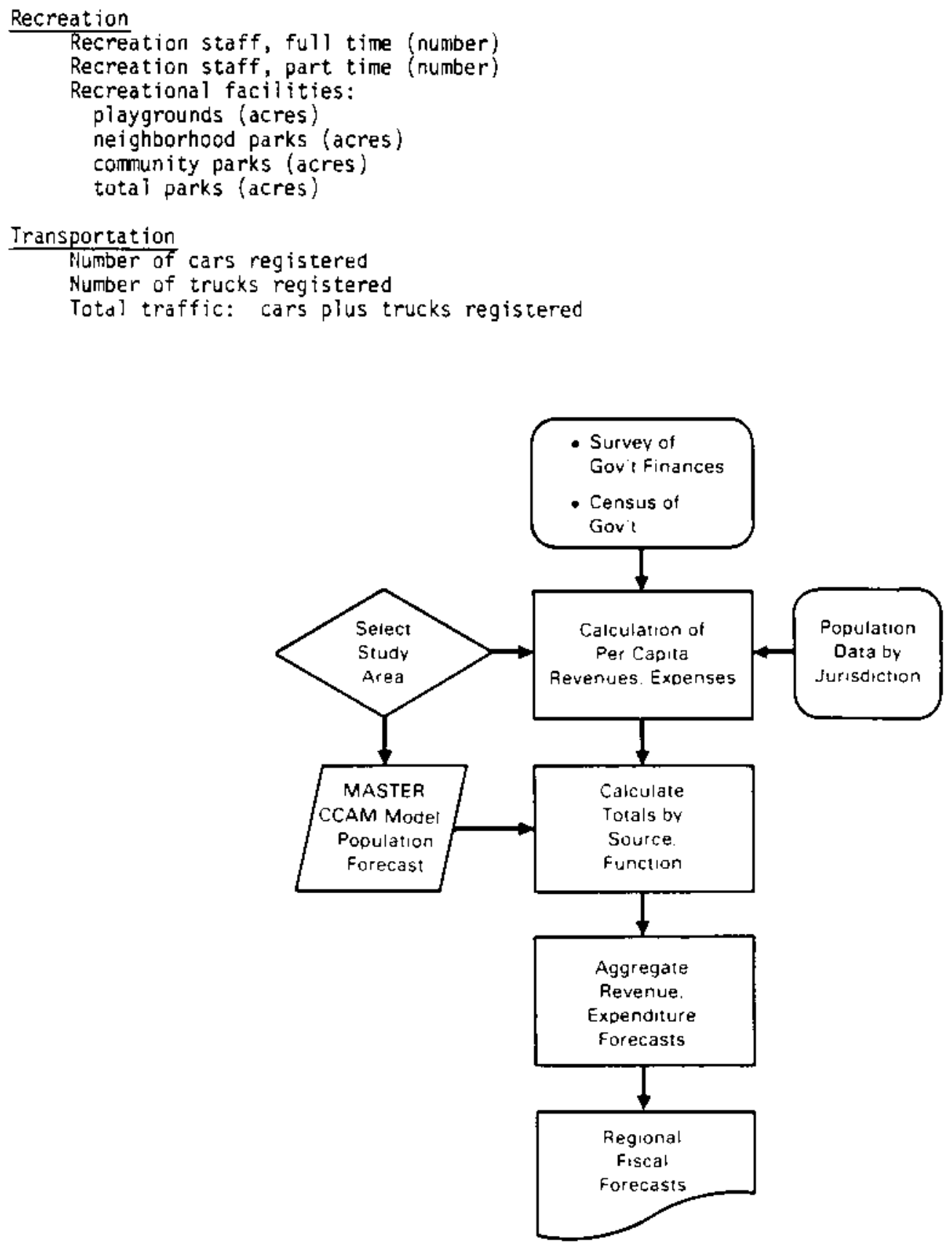

FIGURE C.5. Simple Schemattc of the FI Model

\section{C.2.1 Socioeconomic Scenarios: Base Case}

This section describes the baseline conditions used in the socioeconomic analys is of the three reference sites. These three sites span a variety of socioecononic circumstances even though they were also used to show a variety of environmental conditions. They can be characterized as foilows:

- small, isolated, growing economy (arid)

- large, integrated, growing economy (cold wet)

- smati, integrated, shrinking economy (warm wet)

In this context, "integrated" means that the regional economy under study has many links through migration and trade with the surrounding regional economies. The greater the degree of such integration, the less identifiable this economy is as a separate entity. 
Table C. 3 shows forecasts for a number of key variables for measuring growth in these reference economies and populations from 1985 to 2020. Central counties and noncentral counties are shown separately. The economies show a wide range of growth rates--from shrinking employment to annul average growth of over 2.5\% per year. In some of these areas, per capita income is growing vigorously (income is growing much faster than population). while in other areas it is declining (population is growing faster than income). None of the areas shows declining population. This is because the cold-wet and warm-wet sites are both quite near large population centers, where their population can be employed even if local employment declines (as it does in the wanm-wet site's noncentral county).

None of the economies examined was assumed to be located at a site so rural and isolated that "boom town" socioeconomic impact conditions would prevail. Unlike the natural resource development projects that led to such impacts in severaT western states in the 1970s, the MRS facility is not tied to a specific resource base. Therefore, it may be located near a reasonably large labor force, preventing many adverse socioeconomic impacts that could occur at very isulated sites.

TABLE C.3. Growth in the Reference-Site Economies and Population without MRS

(Population and employment in thousands; incume in miltion 19855)

\begin{tabular}{|c|c|c|c|c|c|c|c|c|c|}
\hline \multirow{2}{*}{$\begin{array}{c}\text { Site, County, ano } \\
\text { Variable }\end{array}$} & \multicolumn{8}{|c|}{ Year } & \multirow{2}{*}{$\begin{array}{l}\text { 35-Year } \\
\text { Average } \\
\text { Annuai } \\
\text { Growth } \\
\text { Rate (品) }\end{array}$} \\
\hline & 1985 & 1990 & 1995 & 2000 & 2005 & 2010 & 2015 & 2020 & \\
\hline$\frac{\text { id Site }}{\text { Central County }}$ & & & & & & & & & \\
\hline $\begin{array}{l}\text { Total Employment } \\
\text { Population } \\
\text { Personal Income }\end{array}$ & $\begin{array}{r}40 \\
110 \\
1,339\end{array}$ & $\begin{array}{r}42 \\
117 \\
1,570\end{array}$ & $\begin{array}{r}44 \\
123 \\
1,817\end{array}$ & $\begin{array}{r}47 \\
129 \\
2,080\end{array}$ & $\begin{array}{r}50 \\
136 \\
2,377\end{array}$ & $\begin{array}{r}54 \\
144 \\
2,737\end{array}$ & $\begin{array}{r}59 \\
154 \\
3,189\end{array}$ & $\begin{array}{r}65 \\
166 \\
3,775\end{array}$ & $\begin{array}{l}1.4 \\
1.2 \\
3.0\end{array}$ \\
\hline $\begin{array}{l}\text { Noncentral County } \\
\text { Total Enpioyment } \\
\text { Population } \\
\text { Personal Income }\end{array}$ & $\begin{array}{r}50 \\
128 \\
1,294\end{array}$ & $\begin{array}{r}55 \\
139 \\
1,520\end{array}$ & $\begin{array}{r}62 \\
151 \\
1,797\end{array}$ & $\begin{array}{r}70 \\
165 \\
2,118\end{array}$ & $\begin{array}{r}80 \\
181 \\
2,498\end{array}$ & $\begin{array}{r}92 \\
201 \\
2,963\end{array}$ & $\begin{array}{r}107 \\
225 \\
3,536\end{array}$ & $\begin{array}{r}124 \\
254 \\
4,256\end{array}$ & $\begin{array}{l}2.7 \\
2.0 \\
3.5\end{array}$ \\
\hline $\begin{array}{l}\text { Totals } \\
\text { Total Employment } \\
\text { Population } \\
\text { Personal Income }\end{array}$ & $\begin{array}{r}89 \\
238 \\
2,633\end{array}$ & $\begin{array}{r}97 \\
256 \\
3,090\end{array}$ & $\begin{array}{r}106 \\
274 \\
3,614\end{array}$ & $\begin{array}{r}117 \\
293 \\
4,198\end{array}$ & $\begin{array}{r}130 \\
317 \\
4,875\end{array}$ & $\begin{array}{r}146 \\
346 \\
5,700\end{array}$ & $\begin{array}{r}166 \\
379 \\
6,725\end{array}$ & $\begin{array}{r}190 \\
419 \\
8,031\end{array}$ & $\begin{array}{l}2.2 \\
1.6 \\
3.2\end{array}$ \\
\hline$\frac{\text { arm-Wet Site }}{\text { Central County }}$ & & & & & & & & & \\
\hline $\begin{array}{l}\text { Total Employment } \\
\text { Population } \\
\text { Personal Income }\end{array}$ & $\begin{array}{r}30 \\
128 \\
1,067\end{array}$ & $\begin{array}{r}27 \\
129 \\
1,025\end{array}$ & $\begin{array}{r}26 \\
133 \\
1,048\end{array}$ & $\begin{array}{r}26 \\
137 \\
1,118\end{array}$ & $\begin{array}{r}27 \\
144 \\
1,235\end{array}$ & $\begin{array}{r}29 \\
151 \\
1,401\end{array}$ & $\begin{array}{r}32 \\
160 \\
1,626\end{array}$ & $\begin{array}{r}35 \\
172 \\
1,920\end{array}$ & $\begin{array}{l}0.4 \\
0.8 \\
1.7\end{array}$ \\
\hline $\begin{array}{l}\text { Noncentral County } \\
\text { Total Employment } \\
\text { Population } \\
\text { Persona? Income }\end{array}$ & $\begin{array}{r}183 \\
780 \\
5,771\end{array}$ & $\begin{array}{r}162 \\
837 \\
5,751\end{array}$ & $\begin{array}{r}148 \\
898 \\
5,896\end{array}$ & $\begin{array}{r}139 \\
966 \\
6,158\end{array}$ & $\begin{array}{r}132 \\
1,048 \\
6,557\end{array}$ & $\begin{array}{r}128 \\
1,138 \\
7,088\end{array}$ & $\begin{array}{r}126 \\
1,232 \\
7,750\end{array}$ & $\begin{array}{r}126 \\
1,329 \\
8,56 !\end{array}$ & $\begin{array}{r}-1.1 \\
1.5 \\
1.1\end{array}$ \\
\hline $\begin{array}{l}\text { Totals } \\
\text { Total Employment } \\
\text { Population } \\
\text { Personal Income }\end{array}$ & $\begin{array}{r}213 \\
908 \\
6,838\end{array}$ & $\begin{array}{r}189 \\
967 \\
6,776\end{array}$ & $\begin{array}{r}174 \\
1,030 \\
6,944\end{array}$ & $\begin{array}{r}165 \\
1,103 \\
7,276\end{array}$ & $\begin{array}{r}160 \\
1,192 \\
7,792\end{array}$ & $\begin{array}{r}158 \\
1,290 \\
8,489\end{array}$ & $\begin{array}{r}158 \\
1,392 \\
9,376\end{array}$ & $\begin{array}{r}161 \\
1,500 \\
10,481\end{array}$ & $\begin{array}{r}-0.8 \\
1.4 \\
1.2\end{array}$ \\
\hline $\begin{array}{l}\text { old-Wet Site } \\
\text { Central County } \\
\text { Total Employinent } \\
\text { Population } \\
\text { Personal Income }\end{array}$ & $\begin{array}{r}42 \\
167 \\
1,440\end{array}$ & $\begin{array}{r}42 \\
1.63 \\
1,407\end{array}$ & $\begin{array}{r}44 \\
161 \\
1,409\end{array}$ & $\begin{array}{r}46 \\
162 \\
1,431\end{array}$ & $\begin{array}{r}50 \\
164 \\
1,491\end{array}$ & $\begin{array}{r}56 \\
169 \\
1,600\end{array}$ & $\begin{array}{r}62 \\
174 \\
1,756\end{array}$ & $\begin{array}{r}71 \\
190 \\
1,993\end{array}$ & $\begin{array}{l}1.5 \\
0.4 \\
0.9\end{array}$ \\
\hline $\begin{array}{l}\text { Noncentral County } \\
\text { Total Employment } \\
\text { Populatior } \\
\text { Personal Income }\end{array}$ & $\begin{array}{r}633 \\
2,658 \\
22,926\end{array}$ & $\begin{array}{r}662 \\
2,667 \\
23,090\end{array}$ & $\begin{array}{r}712 \\
2,701 \\
23,650\end{array}$ & $\begin{array}{r}777 \\
2,770 \\
24,509\end{array}$ & $\begin{array}{r}864 \\
2,871 \\
26,016\end{array}$ & $\begin{array}{r}978 \\
3,030 \\
28,392\end{array}$ & $\begin{array}{r}1,125 \\
3,185 \\
31,757\end{array}$ & $\begin{array}{r}1,273 \\
3,566 \\
36,712\end{array}$ & $\begin{array}{l}2.0 \\
0.8 \\
1.4\end{array}$ \\
\hline $\begin{array}{l}\text { Totals } \\
\text { Total Employment } \\
\text { Population } \\
\text { Persunal Income }\end{array}$ & $\begin{array}{r}574 \\
2,825 \\
24,366\end{array}$ & $\begin{array}{r}704 \\
2,830 \\
24,497\end{array}$ & $\begin{array}{r}756 \\
2,862 \\
25,069\end{array}$ & $\begin{array}{r}823 \\
2,932 \\
25,940\end{array}$ & $\begin{array}{r}914 \\
3,035 \\
27,507\end{array}$ & $\begin{array}{r}1,034 \\
3,199 \\
29,992\end{array}$ & $\begin{array}{r}1,188 \\
3,359 \\
33,513\end{array}$ & $\begin{array}{r}1,344 \\
3,756 \\
38,705\end{array}$ & $\begin{array}{l}2.0 \\
0.8 \\
1.3\end{array}$ \\
\hline
\end{tabular}

Source: MASTER model base case simulations. 


\section{C.2.2 Socioeconomic Scenarios: MRS Assumptions}

This section describes the economic inputs assumed in order to estirate the impacts of the MRS facility. Two different concepts were examined. Except for the prevailing annual wage rates in various industries, which were supplied by the MASTER Model simulation, the direct impact and indirect impact of the MRS facility was assumed to be invariant by site. Table C.4 shows the levels of direct MRS employment and indirect employment assumed each year for both the sealed storage cask and field drywe il concepts. This employment was estimated for each industry and added to the base case forecast in each year. Indirect employment was estimated for each year by first taking the U.S. input-output tabie's dollars of indirect purchases by industry per million dollars of output in construction (construction phase) and government (operations and decomissioning phases) and then multiplying times employment per million doliars of output by industry. The manufacturing component of indirect employment was subtracted from total indirect enployment because it is likely that manufactured materials (e.g.s steel, cement, and lumber) used in the MRS facility would come from outside the 50-mile region imediately surrounding the MRS $f_{d}$ cility. The resulting estimate of total indirect employment is shown in the last column of Table C.4. The MASTER niodel was run at each of the three sites with the changes to direct and indirect employment shown in Table l. 4 as inputs.

TABLE C.4. Direct Employment and Expenditure Estinates for an MRS Facility

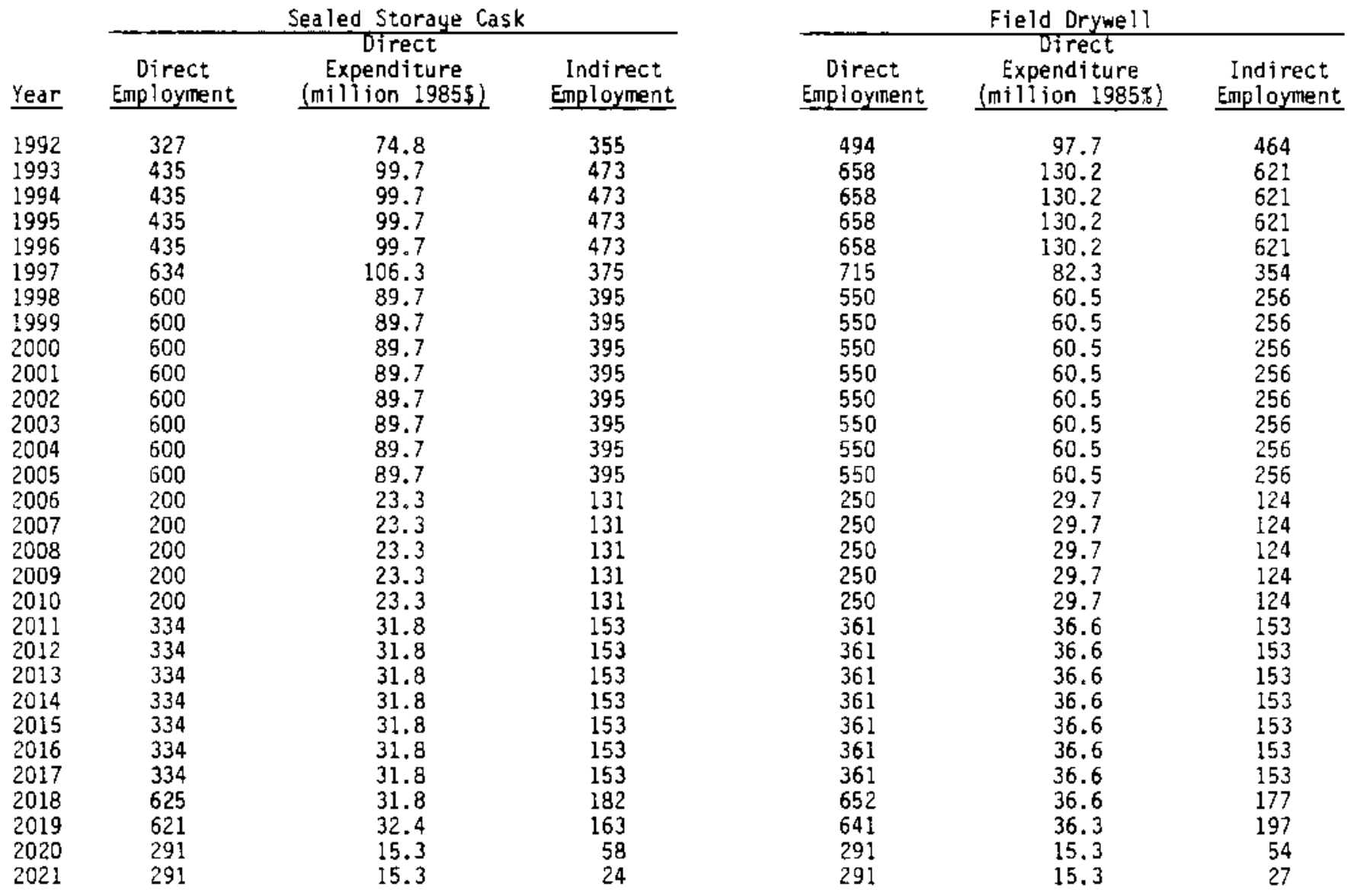

In most cases, this procedure overestimates impacts since it is implicitiy assumed that the region surrounding the MRS site would supply all required business services to the site (other than manufacturing). This may not be the case, since some services (such as insurance, freight furwarding, etc.) may be supplied from outside the region, resulting in an overstatement of indirect employment. Conversely, in those regions where local manufacturing of steel, cement, machinery, and lumber would be available, the procedure followed in this document would result in an underestimate of socioeconomic impacts. With site-specific information, a more precise determination could be made. 


\section{C.3 VALIDATION}

Extensive validation tests have been done on the MASTER model. These tests have included accuracy tests for both in-sample and out-of-sample historical forecasts. In model development, data from 1967 to 1976 were used to estimate the mudel equations. Four years of data (1977 through 1980) were held back from the data set used in estimation in order to perform the out-of-sample test. For the in-sample test, the model was simulated over the in-sample historical period for each MSA/ROSA in the United States, as if actual values for the model's dependent variables were unknown.

The MASTER model "predicted" a series of historical values for each dependent variable. Periodto-period percentage changes in the predicted values of each dependent variable were compared to actual historical period-to-period percentage changes. A sumary statistic, Theil's $U_{1}$ (Theil 1966) was calculated for each dependent variable and region. A value of $U_{1}=0$ indicates a perfect forecast while $U_{1}=1$ would indicate that MASTER forecasts percentage changes $i$ dependent variables no better than a "naive" model in which period-to-period percentage changes were predicted as a constant. To cite one typical example of the outcome, the Portiand, Oregon, MSA $U_{1}$ was never larger than 0.03 (very close to perfect). For almost all variables, $U$, was less than 0.004 . For all of Census Division Six (Pacific: Washington, Oregon, and California). U, was less than 1.0 for two-thirds of the 53 dependent variables. (a)

In the out-of-sample historical forecasts, the model was simulated over the period 1976-1980 as if the historical data at each MSA/ROSA were unknown; then the forecasted vaiues were compared to actual values. Forecasts were prepared for several medium-size MSAs selected at random. The mean absolute percent error (MAPE) of the forecast was estimated for each dependent variable. Some key results are shown in Table C.5.

TABLE C.5. Mean Absolute Percent Error of Out-of-Sample Forecast, $1976-1980$

\begin{tabular}{lc} 
MSA and Variable & $\begin{array}{c}\text { Mean Absolute } \\
\text { Percent Error } \\
\text { of Forecast }\end{array}$ \\
\cline { 2 - 2 } Albany, New York & \\
Total Employment & 3.88 \\
Personal Income & 2.35 \\
Population & 2.80 \\
Alkron, Ohio & \\
Total Employment & 3.88 \\
Personal Income & 3.27 \\
Population & 1.58 \\
Portland, Oregon & \\
Total Employment & 3.38 \\
Personal Income & 1.79 \\
Population & 1.53 \\
Orlando, Florida & \\
Total Employment & \\
Personal Income & \\
Population & 9.77 \\
Source: Adams et al. 1983. & 5.36 \\
\end{tabular}

These results are as good as other regional models' in-sample MAPEs, (b) except for Orlando. In the Orlando case, a large, exogenous increase in construction employment occurred in the actual historical data because of the construction of Walt Disney World and related facilities. This was not includeo in the MASTER test forecast; even so, the forecast was fairly accurate.

To determine whether accurate forecasts could be produced for small-to-medium size econonic areas undergoing rapid exogenous economic change, MASTER was used to perform an out-of-sample forecast for the Richland-Kennewick-Pasco MSA (Benton and Franklin Counties, Hashington). This was an especially chatlenging test because this area's economy has depended historically on rapidiy-changing construction of major energy projects and on federal government funding cycles at the Hanford nuclear reservation. In addition, a

(a) This is an extremely good predictive performance, since the model was not calibrated in this test for particular factors that might have caused a given MSA's historical experience to be unusual. Also, it must be kept in mind that predicting percentage changes is more difficult than predicting the levels of the dependent variables forecasted by MASTER since the changes are often a more volatile time series.

(b) See, for example, Glickman 1977, p. 69. 
significant portion of these construction and nuclear workers commute from outside the two county area--from WalTa Walla, Yakima, Unatilla (Oregon), and even Spokane. Since there were very few data available on the residence of exogenous workers, no adjustment was made for this in the historical forecast, putting a ${ }^{3 j k e l y}$ upward bias on predicted population and predicted wage income. No adjustment was made for overtime or travel pay at the Washington Public Power Supply System Plants, which tends to cause income to be underpredicted. In spite of this, the MASTER model performed very well in this out-of-sample validation test. Results are shown for key variables in Table C.6.

TABLE C.6. Validation Test Forecast Results of the MASTER Model Versus Actual Values for Key Variables, Richland-Kennewick-Pasco Metropolitan Statistical Area, 1976-1981

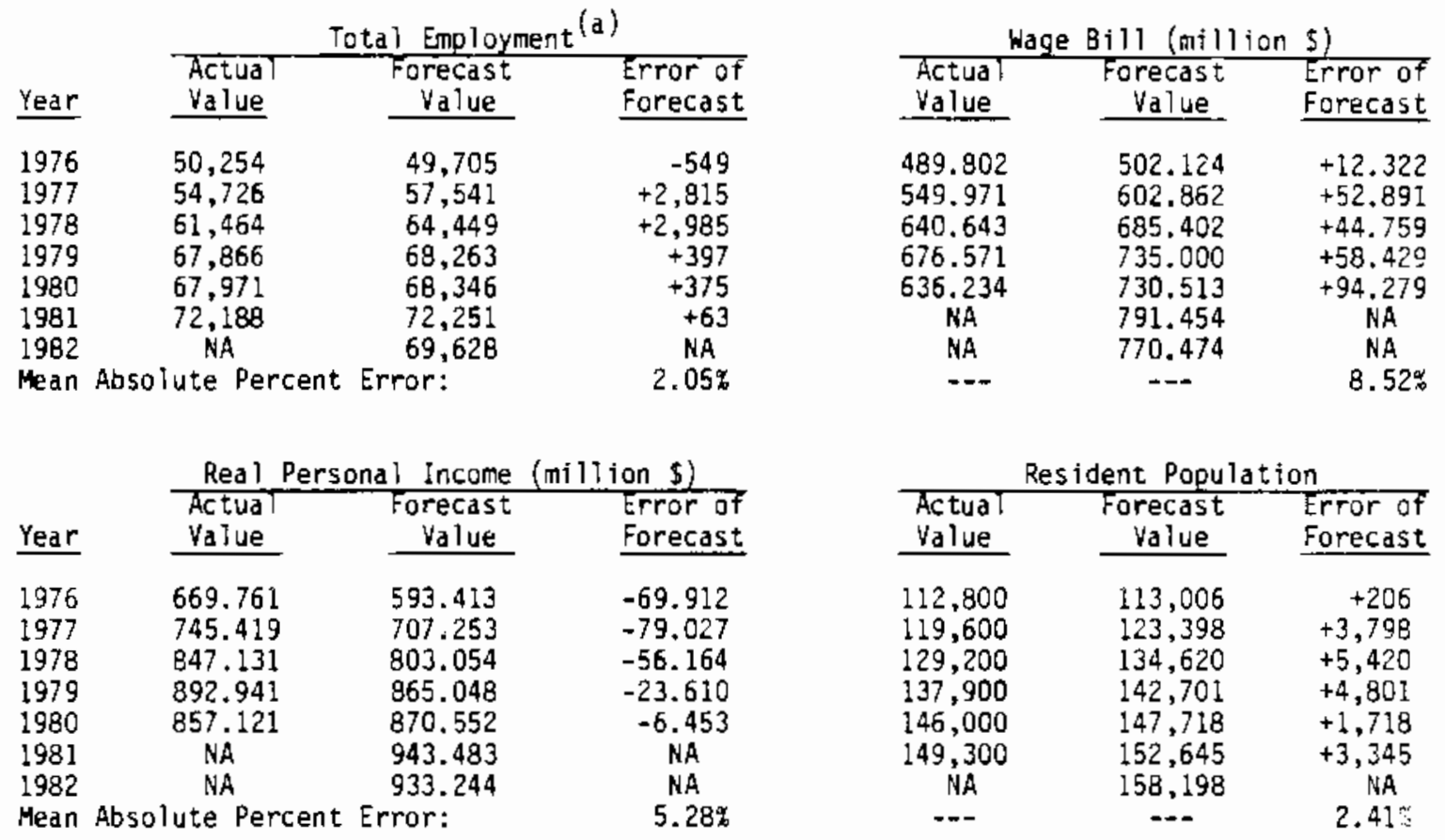

(a) Includes both wage and salary employment and self-empioyed.

The MASTER model forecasts well for the Richland-Kennewick-Pasco MSA, in spite of the serious difficulties in the actual economic data series for the area. Note that for employment, the most reliable of these series and the least affected by residence considerations, MASTER is very good. It thus appears MASTER is an adequate model for small area impact analysis.

The CCAM and FI models were run for the MRS ED in a contingent forecast mode that simpiy assumed constant per capita historical revenue, expenditure, and service rates rather than trying to forecast these through time. Therefore, since no predictions of changes in these rates were made, and since these rates ac change, it was not considered meaningful to subject CCAM and DCFI to the same kinds of predictive checks as were conducted for MASTER. These codes instead were confimed with hand calculations to determine that they produced expected results, given their inputs.

\section{4 REFERENCES}

Adams, R. C., M. J. Scott, R. J. Moe, P. Back, and F. E. Hopkins. 1993. The Metropolitan and State Economic Regions (MASTER) Model - Model Documentation. PNL-4698, Pacific Northwest Laboratory, Richland, Washington.

Adams, R. C., M. J. Moe, and M. J. Scott. 1983. The Metropolitan and State Economic Regions (MASTER) Model - Overview. PNL-4749, Pacific Northwest Laboratory, Richland, Washington.

Glickman, N. J. 1977. Econometric Analysis of Regional Systems: Explorations in Model Building and Policy Analysis. Acadenic Press, New York.

Kmenta, j. 1971. Elements of Econometrics. Macmillan, New York.

Thei1, H. 1966. Applied Economic Forecasting. North Holland Publishing Company, Amsterdam, The Netherlands. 
No. of

Copies

OFFSITE

6 B. C. Rusche

Office of Civilian Radioactive waste Management

U.S. Department of Energy

RH-1

Washington, DC 20545

J. R. Hilley

Office of Civilian Radioactive Waste Management

U.S. Department of Energy

RH- 30

Washington, OC 20545

K. A. Kiein

Office of Civilian Radiaactive

was te Management

U.S. Department of Energy

RH-31

Hashington, OC 20545

J. H. Carlson

Office of Civilian Radioactive

Waste Management

U.S. Department of Energy

RH-32

washington, DC 20545

6 P. Gross

U.S. Department of Energy

Oak Ridge Operations office

Oak Ridge, Tennessee 37830

30 DOE Technical Information Center

J. H. Voss

Goider Associates

2950 Northup Way

Bellevue, WA 98004

W. D. Woods

The Ralph M. Parsons Company

100 West Walnut Street

Pasadena, CA 91124
No. of

Copies

ONS ITE

5 OOE Richland Operations Office

P. A. Craig (2)

R. B. Goranson

R. D. Izatt

H. E. Ransom

145 Pacific Northwest Laboratory

R. L. Aaberg

H. B. Ashton

W. W. Ballard

J. L. Braitman

C. E. Cushing

J. F. Fletcher

J. J. Fuquay

R. M. Gale

R. J. Hall (30)

R. E. Heineman

J. N. Holloway

G. M. Holter

D. S. Jackson

W. S. Keliy

D. K. Kreid

M. R. Kreiter

J. D. Ludwick

A. Marshall

P. N. McDuffie

J. L. MCEl roy

G. W. MCNair

D. F. Newman

D. R. Payson

H. D. Richrnond

R. E. Rhoads

L. C. Schmid

K. J. Schneider

M. J. Scott

G. H. Sewart

R. L. Shaub

H. R. Shay

D. J. Silviera (70)

A. L. Slavich

R. I. Smith

D. L. Strenge

M. B. Triplett

C. H. Unruh

M. K. White

L. D. Willians

T. W. Wood

Publishing Coordination (2)

Techrical Information (5) 
